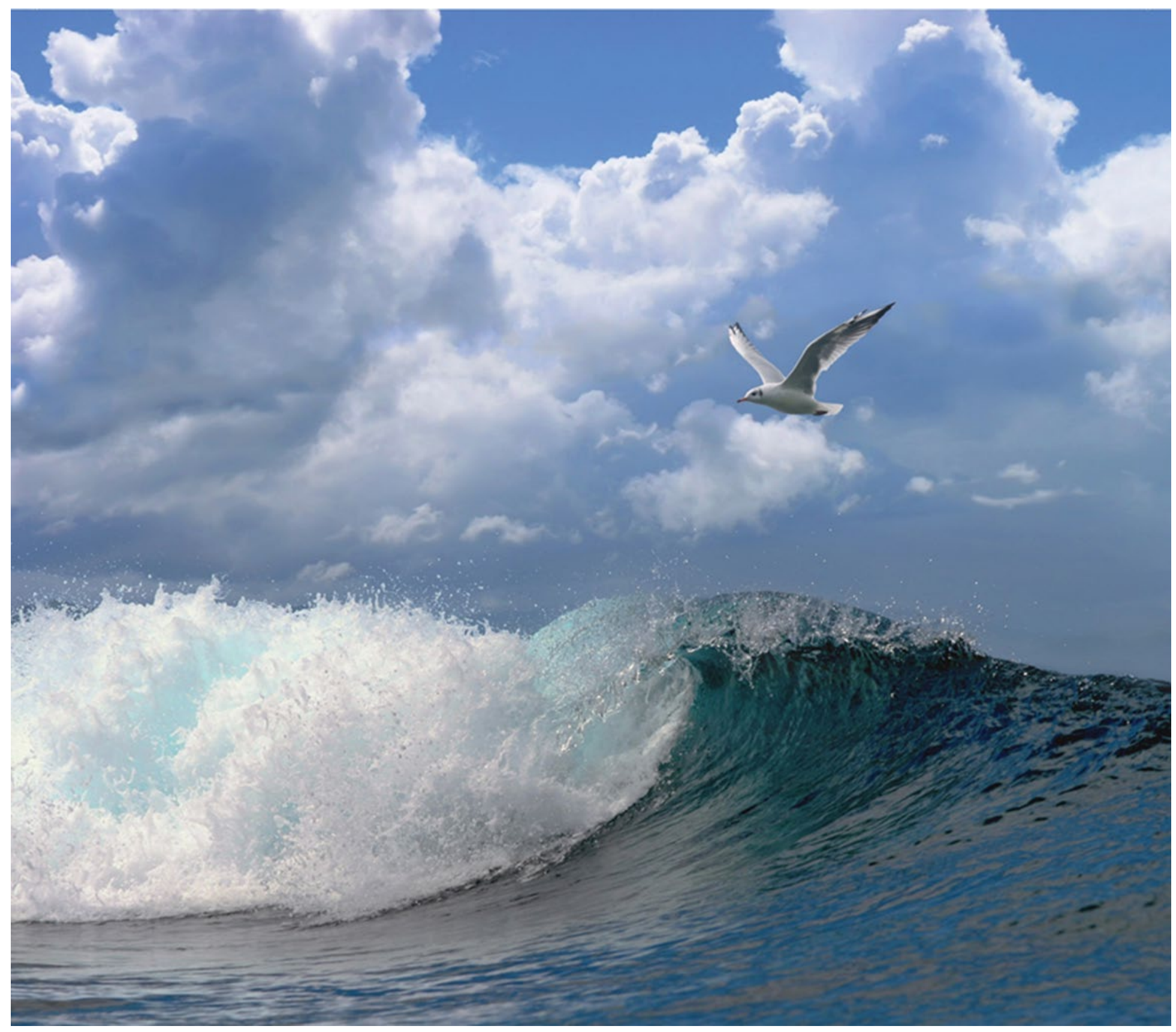

\title{
Achtergrondrapportage Programmeringsstudies Landbouw, Water en Voedsel: Noordzee en Visserij
}

Auteur(s): S. Smith (1), N.A. Steins (1), I. Ammerlaan (3), L. van den Bogaart, (1) O.G. Bos (1) M. Maarse (2), J. van Rijn (1), A. Schadeberg (1), J. Tamis (1), S. Tatman (2).
(1) Wageningen Marine Research
(2) Deltares
(3) Wageningen University - Agrotechnology \& Food Sciences Group 


\section{Achtergrondrapportage Programmeringsstudies Landbouw, Water en Voedsel: Noordzee en Visserij}

Auteur(s): $\quad$ S. Smith (1), N.A. Steins (1), I. Ammerlaan (3), L. van den Bogaart, (1) O.G. Bos (1) M. Maarse (2), J. van Rijn (1), A. Schadeberg (1), J. Tamis (1), S. Tatman (2).

(1) Wageningen Marine Research

(2) Deltares

(3) Wageningen University - Agrotechnology \& Food Sciences Group

Dit onderzoek is uitgevoerd door Wageningen Marine Research in opdracht van en gefinancierd door het Ministerie van Landbouw, Natuur en Voedselkwaliteit, in het kader van het Beleidsondersteunend onderzoekthema Coördinatie Topsectoren (projectnummer BO-34-001-047) 
Keywords: kennisvragen, programmeringsstudies, Noordzee, visserij, innovatie, energietransitie

Opdrachtgever: $\quad$ Ministerie van Landbouw, Natuur en Voedselkwaliteit

T.a.v.: Dr. Ir. J.G. de Wilt

Postbus 20401

2500 EK Den Haag

BO-34-001-047

Dit rapport is gratis te downloaden van https://doi.org/10.18174/497075

Wageningen Marine Research verstrekt geen gedrukte exemplaren van rapporten.

Wageningen Marine Research is ISO 9001:2015 gecertificeerd.

(C) Wageningen Marine Research

Wageningen Marine Research, instituut binnen de rechtspersoon Stichting

Wageningen Research, hierbij vertegenwoordigd door Dr. M.C.Th. Scholten, Algemeen directeur

KvK nr. 09098104,

WMR BTW nr. NL 8113.83.696.B16.

Code BIC/SWIFT address: RABONL2U

IBAN code: NL 73 RABO 0373599285
Wageningen Marine Research aanvaardt geen aansprakelijkheid voor gevolgschade, noch voor schade welke voortvloeit uit toepassingen van de resultaten van werkzaamheden of andere gegevens verkregen van Wageningen Marine Research opdrachtgever vrijwaart Wageningen Marine Research van aanspraken van derden in verband met deze toepassing.

Alle rechten voorbehouden. Niets uit deze uitgave mag weergegeven en/of gepubliceerd worden, gefotokopieerd of op enige andere manier gebruikt worden zonder schriftelijke toestemming van de uitgever of auteur. 


\section{Inhoud}

Samenvatting

$\begin{array}{llr}1 & \text { Inleiding } & 7\end{array}$

$\begin{array}{llr}1.1 & \text { Achtergrond } & 7\end{array}$

$\begin{array}{lll}1.1 .1 & \text { Missies } & 7\end{array}$

1.2 Vraagstelling $\quad 8$

1.2.1 Programmeringsstudies Duurzame Noordzee en Visserij 8

$\begin{array}{lll}1.2 .2 & \text { Leeswijzer } & 8\end{array}$

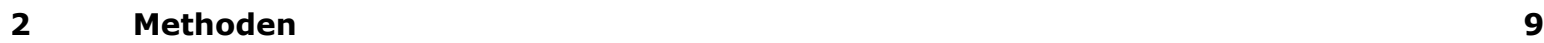

2.1 Gezamenlijke aanpak $\quad 9$

2.2 Kennis- en innovatievragen 9

2.2.1 Verzamelen vragen 9

2.2.2 Aanpak analyse vragen $\quad 11$

2.3 Prioritering kennis- en innovatievragen 11

2.3.1 Workshop 23 april 2019: prioritering en aanpak witte vlekken 11

$\begin{array}{lll}2.3 .2 & \text { MMIPs } & 12\end{array}$

2.3.3 Workshop 14 mei 2019: Inhoud geven aan kennis- en innovatie 12

2.3.4 Afstemming topsectoren buiten het LWV-domein 13

$\begin{array}{lll}2.4 & \text { Beschikbare financieringsmogelijkheden } & 13\end{array}$

$\begin{array}{llr}3 & \text { Financieringsmogelijkheden } & 14\end{array}$

3.1 Algemeen $\quad 14$

3.2 Subsidies $\quad 14$

$\begin{array}{lll}3.2 .1 & \text { NWO } & 14\end{array}$

$\begin{array}{lll}3.2 .2 \text { EU } & 14\end{array}$

$\begin{array}{lll}3.2 .3 & \text { Topsectoren } & 15\end{array}$

$\begin{array}{lll}3.2 .4 & \text { Ministeries } & 15\end{array}$

$\begin{array}{lll}3.2 .5 & \text { Overig } & 15\end{array}$

$4 \quad$ Uitgebreide resultaten Programmeringsstudie Duurzame Noordzee 17

\begin{tabular}{ll}
4.1 & Inleiding \\
\hline
\end{tabular}

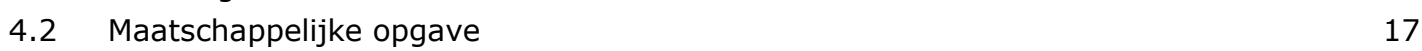

\begin{tabular}{ll}
4.3 & Lopend onderzoek \\
\hline
\end{tabular}

$\begin{array}{ll}4.4 \text { Witte vlekken } & 18\end{array}$

4.4.1 Mind-map kennis- en innovatievragen 18

4.4.2 Witte vlekken analyse kennis - en innovatievragen (excl. visserij) 19

4.5 Kennis- en innovatiethema's en prioritaire onderwerpen 24

$\begin{array}{lll}4.6 & \text { Financiering kennis- en innovatieopgaven } & 25\end{array}$

$5 \quad$ Uitgebreide resultaten Programmeringsstudie Visserij $\quad 27$

$\begin{array}{lll}5.1 & \text { Inleiding } & 27\end{array}$

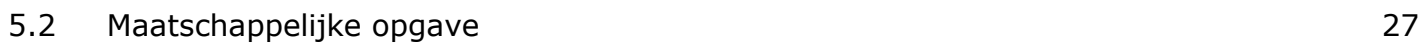

\begin{tabular}{ll}
5.3 & Lopend onderzoek \\
\hline
\end{tabular}

$\begin{array}{lll}5.4 & \text { Witte vlekken } & 28\end{array}$

5.4.1 Mind-map kennis- en innovatievragen 28

5.4.2 Witte vlekken analyse kennis - en innovatievragen $\quad 29$

5.5 Kennis- en innovatiethema's en prioritaire onderwerpen 33

$\begin{array}{lll}5.6 & \text { Financiering kennis- en innovatieopgaven } & 34\end{array}$ 
Literatuur

Verantwoording

Bijlage 1 Interviewvragen

Bijlage 2 Enquêtevragen

Bijlage 3 Verslag workshop beleid en onderzoek 23 april 2019

Bijlage 4 Verslag stakeholder workshop 14 mei 2019

72

Bijlage 5 Financieringsmogelijkheden

90

Bijlage 6 Kennis- en innovatievragen Noordzee: Wind op Zee in relatie tot Ecosysteem, Natuur en Meervoudig Ruimtegebruik

Bijlage 7 Kennis- en innovatievragen Energie (anders dan wind) in relatie tot Ecosysteem, Natuur en Meervoudig Ruimtegebruik

Bijlage 8 Kennis- en innovatievragen Maricultuur

Bijlage 9 Kennis- en innovatieopgaven geschikt voor topsectorfinanciering

Bijlage 10 Kennis- en innovatieopgaven geschikt voor publieke financiering

Bijlage 11 Kennis- en innovatievragen Visserij

Bijlage 12 MMIP Duurzame en veilige Noordzee 


\section{Samenvatting}

Deze Achtergrondrapportage Programmeringsstudies Landbouw, Water en Voedsel: Noordzee en Visserij hoort bij twee andere, afzonderlijke programmeringsstudies: Duurzame Noordzee (Steins et al., 2019) en Visserij (Smith et al., 2019). Deze programmeringsstudies schetsen een beeld van de onderzoeks- en innovatieopgaven die nodig zijn om de ambities van het ministerie van Landbouw, Natuur en Voedselkwaliteit (LNV) ten aanzien van duurzame visserij en duurzaam meervoudig gebruik van de Noordzee waar te maken. Het belang en de potenties van de Noordzee zijn groot, zowel voor natuur, voedselvoorziening (visserij en in de toekomst maricultuur), transport over water, delfstoffenwinning, kustverdediging, energievoorziening en recreatie. De exploitatie van de hulpbronnen die de Noordzee biedt zijn echter aan grenzen gebonden. Dit geldt niet alleen voor de traditionele bronnen zoals visbestanden en delfstoffenwinning, maar ook voor nieuwe hulpbronnen, zoals de geplande uitrol van (wind)energiewinning op zee. Tegen deze achtergrond heeft het ministerie van LNV de volgende missie vastgesteld als onderdeel van de kennis- en Innovatieagenda LNV (2019-2030):

"Missie E. Duurzame en veilige Noordzee, oceanen en binnenwateren: Voor de mariene wateren is er in 2030 en voor rivieren, meren en estuaria in 2050 een balans tussen enerzijds ecologische draagkracht en waterbeheer (waterveiligheid, zoetwatervoorziening en waterkwaliteit) en anderzijds de opgaven voor hernieuwbare energie, voedsel, visserij en andere economische activiteiten." (Ministerie van LNV, 201, p.28).

Binnen deze missie zijn aparte subthema's met ambities en innovatieopgaven opgenomen voor de Noordzee en Visserij. In dit achtergrondrapport wordt gerapporteerd hoe kennis- en innovatievragen voor Noordzee en Visserij, die in de respectievelijke programmeringsstudies zijn uitgewerkt (Steins et al., 2019; Smith et al., 2019) verzameld zijn. Verder bevatten de bijlagen uitgebreide lijsten met kennis- en innovatievragen, die in de hoofdrapporten in samengevatte vorm gepresenteerd zijn.

\section{Duurzame Noordzee}

Bij de opstelling van kennis- en innovatievragen rondom de Noordzee, is gebruik gemaakt van verschillende secundaire bronnen, waarvan de belangrijkste de Kennisagenda Noordzee 2030 (Ministeries van IenW en van LNV, 2018) en het Ontwerp van het Klimaatakkoord (Klimaatberaad, 2018) zijn. Voor de programmeringsstudie Noordzee is ook gebruik gemaakt van primaire bronnen zoals twee stakeholder workshops, afstemming met de Topsectoren Energie en Maritiem en overig divers overleg met stakeholders.

$\mathrm{Na}$ de inventarisatie van de vragen is op basis van clustering een analyse uitgevoerd waarbij de kennis- en innovatievragen zijn uitgewerkt in een Excel spreadsheet; ze zijn eerst gecategoriseerd door een breed scala aan onderwerpen en vragen in te vullen, en daarna gesorteerd door gebruik van draaitabellen. Hierna is een mind-map gemaakt, waarin de vragen en de onderwerpen van de vragen in relatie tot elkaar zijn gebracht en gevisualiseerd. Op deze manier is te zien over welke onderwerpen de verschillende vragen gaan en welke termen vaak met elkaar in verband worden gebracht. Omdat de focus ligt op het identificeren van kennis- en innovatievraagstukken die nog niet opgepakt worden onder bestaande programma's of projecten, de zogenaamde witte vlekken, is in de vervolg analyse alleen verder gekeken naar die kennis- en innovatievragen die volledig, dan wel als gedeeltelijke, witte vlek zijn geïdentificeerd. Dit resulteerde in witte vlekken rond de thema's energie, voedsel (visserij en maricultuur), overig gebruik en ecosysteem/natuur. Vervolgens zijn tien vragen als prioriteit geïdentificeerd en voorgelegd in workshops met vertegenwoordigers van overheid, industrie, Ngo's en onderzoek. Tijdens deze twee dagen zijn ook discussies gevoerd over welke initiatieven geïnitieerd moeten worden om prioritaire thema's aan te pakken en hoe deze gefinancierd zouden kunnen worden. 
De uitgebreide resultaten voor de Programmeringsstudie Duurzame Noordzee (exclusief visserij) met een overzicht van de resultaten van de witte vlekken analyse staan uitgebreid beschreven in hoofdstuk 4.

Op basis van de analyse van de witte vlekken worden drie centrale thema's onderscheiden:

- Monitoring, modellering, data- en informatiemanagement en afwegingskaders voor menselijk medegebruik binnen de draagkracht van het Noordzee ecosysteem;

- Natuurvriendelijke aanleg van grootschalige bouwwerken voor energieproductie en stimulering van natuur hierbinnen;

- Meervoudig ruimtegebruik door combinaties van energie infrastructuur met voedselproductie (visserij en maricultuur).

Daarnaast is er een vierde thema dat binnen de ambities van de vastgestelde missie rond Duurzame Noordzee, Oceanen en Binnenwateren valt, maar dat in de inventarisatie van de kennis- en innovatievragen weinig prominent was: Vermindering van afval in zee. Dit thema werd echter wel in de prioriteringssessies met stakeholders benoemd als een prioritair onderwerp. Om deze redenen wordt dit thema als vierde centrale thema toegevoegd.

Voor ieder van de kennisvragen is ook in kaart gebracht of het een kennis- of innovatieopgave of beide is, of er lopende monitoring of basisgegevens beschikbaar zijn (en binnen welk programma), of er lopende onderzoeksprogramma's zijn en of er (voor zover bekend) onderzoeksvoorstellen zijn ingediend. Tevens is ook aangegeven of de vraag zich zou lenen voor topsectorfinanciering. In de Bijlagen zijn hiervan uitgebreide overzichten te vinden. Deze kunnen als referentie dienen bij het vormgeven van concrete onderzoeksvragen.

De analyses van de kennis- en innovatievragen inclusief de input tijdens de workshops zijn gebruikt om de concept-Meerjarige Missiegedreven Innovatieprogramma's (MMIPs) op te stellen voor Duurzame en Veilige Noordzee (Missie E).

\section{Maricultuur}

In relatie tot de Noordzee is het belangrijk te vermelden dat er een overlap bestaat met Missie B, Klimaatneutrale landbouw en voedselproductie. Binnen deze missie is het onderwerp Biogrondstoffen opgenomen, inclusief grootschalige productie van zeewier uit de Noordzee. $\mathrm{Er}$ is een aparte Prgrammeringsstudie Biogrondstoffen (Elbersen et al., 2019). De inventarisatie en analyse van kennisvragen rond zeewier is in nauwe samenwerking tussen de projectteams voor Duurzame Noordzee, Visserij en Biogrondstoffen (zeewier) uitgevoerd. Maricultuur (zeewier) is opgenomen in de Excel spreadsheet en ook onderdeel geweest van de workshops. De resultaten zijn gebruikt voor het opstellen van het concept-MMIP Zeewierproductie en de Programmeringsstudie Biogrondstoffen (Elbersen et al., 2019).

\section{Visserij}

Voor het onderdeel Visserij is ongeveer dezelfde werkwijze gevolgd als voor het onderdeel Duurzame Noordzee. Kennis- en innovatievragen afkomstig uit het Noordzee 2030 proces zijn aangevuld met vragen uit een online-enquête, interviews en twee workshops. De vragen zijn net als bij 'Duurzame Noordzee' gecategoriseerd en geclusterd. Voor visserij zijn hiervoor subthema's uit de missie voor Visserij van LNV gebruikt: Minder emissies, Betere arbeidsomstandigheden, Dierenwelzijn, Minder bodemberoering, Selectiever vissen, aangevuld met twee extra subthema's die tijdens de workshops naar voren kwamen: Sterker beheer en Systeemveranderingen. Een derde subthema 'Circulaire visserij' is vanuit de TKI Blue Growth toegevoegd, maar deze wordt hier niet behandeld. De kennis- en innovatievragen zijn net als bij Duurzame Noordzee op een aantal manieren gecategoriseerd en geprioriteerd, waarna een programmeringsadvies is opgesteld (in Smith et al. 2019) en een conceptMeerjarige Missiegedreven Innovatieprogramma (MMIP) voor Visserij. In de Bijlagen van dit rapport staan verder uitgebreide lijsten met kennis- en innovatievragen, die handig zullen zijn wanneer nagedacht wordt over concrete onderzoeksvragen. 


\section{Inleiding}

Dit rapport dient als achtergrondrapport bij de programmeringsstudies Duurzame Noordzee (Steins et al., 2019), Duurzame Visserij (Smith et al., 2019) en de Programmeringsstudie Biogrondstoffen, onderdeel Zeewier (Elbersen et al., 2019). Dit achtergrondrapport bevat een uitgebreide beschrijving van de gebruikte methodiek en van de resultaten, waarvoor in de hoofdrapporten geen ruimte was. De studies hebben een uitgebreide lijst met kennis- en innovatievragen opgeleverd, die in dit achtergrondrapport zijn opgenomen. In de hoofdrapporten worden alleen de belangrijkste kennis- en innovatievragen weergeven.

\subsection{Achtergrond}

Nederland staat voor een aantal grote maatschappelijke opgaven rond voedselproductie, klimaatverandering en duurzaam gebruik en beheer van grote wateren. Binnen het thema Landbouw, Water, Voedsel (LWV) heeft het Ministerie van Landbouw, Natuur en Voedselkwaliteit (LNV) zes missies gedefinieerd om de maatschappelijke opgaven aan te pakken en ook kansen te kunnen bieden voor het versterken van de concurrentiekracht van het Nederlandse bedrijfsleven. De missies zijn in april 2019 vastgesteld door het kabinet. De missies moeten prikkelen tot ambitieus onderzoek in een gezamenlijke publiek-private aanpak (via de topsectoren), waarbij een puur publieke inzet niet bij voorbaat wordt uitgesloten. Er zijn al diverse programma's, projecten en bijbehorende financieringsinstrumenten die zich richten op het realiseren van de missies en de daarbij horende kennisvragen. Een goed overzicht hiervan ontbreekt echter in sommige gevallen.

Programmeringsstudies zijn gericht op het krijgen van een goed beeld van wat er loopt op een bepaald gebied, welke partijen daarmee bezig zijn en welke initiatieven er specifiek vanuit de topsectoren zouden moeten worden geïnitieerd. Op deze wijze kan LNV meer focus aanbrengen bij het uitzetten van onderzoek en de beoordeling van de projecten van de topsectoren Agro \& Food en Tuinbouw \& Uitgangsmaterialen.

\subsubsection{Missies}

De zes missies zijn thematisch ingedeeld:

1. A: Kringlooplandbouw

2. B: Klimaatneutrale landbouw en voedselproductie

3. C: Klimaatbestending landelijk en stedelijk gebied

4. D: Gewaardeerd, gezond en veilig voedsel

5. E: Duurzame en veilige Noordzee, oceanen en binnenwateren

6. F: Nederland is de best beschermde en leefbare delta ter wereld

De programmeringsstudies Duurzame Noordzee (Steins et al., 2019) en Duurzame Visserij (Smith et al., 2019) vallen onder Missie E: Duurzame en veilige Noordzee, Oceanen en Binnenwateren. De missie is voor het LWV-gedeelte als volgt omschreven: "Voor de mariene wateren is er in 2030 en voor rivieren, meren en estuaria in 2050 een balans tussen enerzijds ecologische draagkracht en waterbeheer (waterveiligheid, zoetwatervoorziening en waterkwaliteit) en anderzijds de opgaven voor hernieuwbare energie, voedsel, visserij en andere economische activiteiten." (Ministerie van LNV, 2019). Binnen deze missies zijn aparte subthema's met ambities en innovatieopgaven opgenomen voor de Noordzee (Tabel 3) en de Visserij (Tabel 13). 


\subsection{Vraagstelling}

Het Ministerie van LNV heeft Wageningen Research gevraagd voor de Missies A t/m E (Ministerie van LNV, 2019) programmeringsstudies uit te voeren.

Een programmeringsstudie bevat de volgende onderdelen:

1. Maatschappelijke opgave: Beschrijving van de maatschappelijk opgave/missie met de context. Welke grote kennis- en innovatie vragen vloeien hieruit voor? Wat kunnen deze bijdragen aan het dichterbij brengen van de oplossing van de opgave?

2. Lopend onderzoek: Beschrijving van het onderzoek dat bij Wageningen Research en elders al loopt, ook afgezet tegen de verwachte resultaten (fundamenteel/toegepast) en in de tijd (lange/korte termijn beschikbaar).

3. Witte vlekken: Welke (onderdelen van) kennis- en innovatievragen worden nog niet of onvoldoende opgepakt? (Expert-oordeel). Aanscherping van deze opgaven.

4. Mogelijke consortia en financiering: Perspectief om deze via een publiek-private aanpak wel of juist niet op te pakken. In beeld brengen potentiële private partijen, bereidheid tot private financiering en mogelijk te vormen consortia (incl. mogelijke kennisinstellingen).

5. Programmeringsadvies: Advies programmering kennis- en innovatieprojecten voor de korte termijn (1-2 jaar) en de iets langere termijn ( 5 jaar).

Als onderdeel van de programmeringsstudies hebben de topsectoren Agro \& Food en Tuinbouw \& Uitgangsmaterialen gevraagd om teksten voor de zogenaamde Meerjarige Missiegedreven Innovatieprogramma's (MMIPs) aan te leveren. Deze MMIPs zijn in juni 2019 aan de topsectoren opgeleverd en opgenomen in de bijlagen bij dit rapport (Bijlagen 12, 13 en 14).

\subsubsection{Programmeringsstudies Duurzame Noordzee en Visserij}

De programmeringsstudies Duurzame Noordzee en Visserij bouwen grotendeels voort op lopende activiteiten (zie Hoofdstuk 2, Methoden) en verbinden deze met elkaar. Gezien de duidelijke overlap tussen de programmeringsstudies voor de Noordzee (Steins et al., 2019) en voor de Visserij (Smith et al., 2019) is in beide programmeringsstudies nauw samengewerkt. Op verzoek van de opdrachtgever is de Programmeringsstudie Noordzee in samenwerking met Deltares uitgevoerd. De beide programmeringsstudies bevatten een beschrijving van de resultaten en methodiek op hoofdlijnen. De uitgebreide methodiek en resultaten voor beide programmeringsstudies staan beschreven in dit achtergrondrapport. Ook is tijdens de uitvoering van de projecten samengewerkt met de programmeringsstudie Biogrondstoffen, onderdeel Zeewierteelt (Elbersen et al., 2019) uit Missie B Klimaatneutrale Landbouw en voedselproductie (Ministerie van LNV, 2019). De drie Programmeringsstudies Noordzee (deze rapportage), Visserij (deze rapportage) en Biogrondstoffen (deel blauwe ruimte) (Elbersen et al., 2019) en de hieruit voortvloeiende MMIPs kunnen niet los van elkaar worden gezien. Vanuit de TKI Blue Growth is na overleg over overlap tussen de verschillende studies het thema 'circulaire visserij' aan de programmeringsstudie Visserij toegevoegd. In deze achtergrondstudie wordt aan het thema 'circulaire visserij' verder geen tekst gewijd, omdat dit buiten de programmeringsstudie Visserij om uitgewerkt is.

\subsubsection{Leeswijzer}

Het volgende Hoofdstuk 2 bespreekt de aanpak voor de inventarisatie en analyse van de kennis- en innovatievragen voor de Programmeringsstudies Noordzee (Steins et al., 2019), Visserij (Smith et al., 2019) en het onderdeel Zeewierteelt uit de Programmeringsstudie Biogrondstoffen (Elbersen et al., 2019). Hoofdstuk 3 geeft de resultaten van de inventarisatie van de bestaande financieringsmogelijkheden weer. Hoofdstuk 4 bevat de uitgebreide analyse van de kennis- en innovatievragen. De prioritaire thema's uit deze analyse zijn uitgewerkt in de Programmeringsstudie Duurzame Noordzee. Hoofdstuk 5 geeft diezelfde analyse voor het onderwerp Visserij. Ook hier zijn de prioritaire onderwerpen nader uitgewerkt in de programmeringsstudie Visserij (Smith et al., 2019). Tenslotte bevatten de bijlagen o.a. de verslagen van de stakeholderworkshops en uitgebreide overzichten met kennis- en innovatievragen. 


\section{Methoden}

\subsection{Gezamenlijke aanpak}

Gezien de overlap tussen de thema's Noordzee, Visserij en Biogrondstoffen (uit de blauwe ruimte) hebben de teams van de programmeringsstudies nauw samengewerkt in de gegevensverzameling en analyses. Het voorliggende hoofdstuk beschrijft de gezamenlijke methodiek.

\subsection{Kennis- en innovatievragen}

Vanuit het Noordzee 2030-programma is door de Ministeries van LNV en Infrastructuur en Waterstaat (IenW) het initiatief genomen om een Kennisagenda op te stellen, waarin de vragen die de verschillende belanghebbenden hebben gesteld tijdens het consultatieproces rond Noordzee 2030, zijn samengevat (Ministeries van IenW en van LNV, 2018). Aan deze vragen is ook een prioritering gegeven met behulp van input van de Wageningen Universiteit \& Research (Wageningen Universiteit, Wageningen Marine Research, Wageningen Economic Research), TU Delft en Deltares. Daarnaast is vanuit de Noordzee 2030 Tafel Kennis onder leiding van het Ministerie van IenW een overzicht gemaakt van de (onderzoeks)programma's die zich met vraagstukken rond het beheer van de Noordzee bezighouden. Wat echter nog niet is gebeurd, is een analyse van vraag en aanbod, met andere woorden: welke kennisvragen zijn afgedekt binnen lopende programma's en welke nog niet. Ook vanuit de kennisinstituten loopt sinds medio januari 2019 een eigen initiatief om de kennisvragen rond Noordzee 2030 in kaart te brengen (hierna: initiatief kennisinstituten), inclusief de vraag waar de gaten liggen.

\subsubsection{Verzamelen vragen}

Voor het verzamelen van de kennis- en innovatievragen is gebruik gemaakt van secundaire bronnen (documenten) en van primaire bronnen (interviews, survey, workshops en overleg).

\subsubsection{Secundaire bronnen}

$\mathrm{Er}$ is al veel kennis over de Noordzee beschikbaar, maar vele onderwerpen vragen om verder onderzoek. Bij de opstelling van kennis- en innovatievragen rondom de Noordzee, is gebruik gemaakt van verschillende secundaire bronnen, waarvan de belangrijkste de Kennisagenda Noordzee 2030 ( Ministeries van IenW en van LNV, 2018) en het Ontwerp van het Klimaatakkoord (Klimaatberaad, 2018) zijn.

Een groot deel van de vragen komt uit de Kennisagenda Noordzee 2030 (Bijlage van de Strategische Agenda en het Uitvoeringsprogramma Noordzee 2030) (Ministerie van LNV \& IenW, 2018). De vragen in deze kennisagenda komen voort uit een intensief overlegproces met overheid, stakeholders en kennisinstellingen. Ook is daarbij gebruik gemaakt van vele Noordzee-documenten met kennisvragen, zijn vragen opgenomen die bij het schrijven van de teksten voor de Noordzee 2030 nota naar voren kwamen en zijn de kennisvragen uit de studie 'De toekomst van de Noordzee' (Matthijsen et al., 2018) meegenomen.

Naast de Kennisagenda Noordzee 2030 is ook gebruik gemaakt van het Ontwerp van het Klimaatakkoord (Klimaatberaad, 2018) om kennis- en innovatievragen te verzamelen.

\subsubsection{Primaire bronnen}

Voor de programmeringsstudies is gebruik gemaakt van de volgende primaire bronnen:

1. Interviews (alleen voor visserij);

2. Online enquête (grotendeels alleen voor visserij);

3. Twee stakeholder workshops;

4. Afstemming met de Topsectoren Energie en Maritiem. 


\section{Interviews}

In tegenstelling tot de Noordzee is er voor de Visserij nog geen kennisagenda beschikbaar. Om inzicht te krijgen in de vraagstukken die belanghebbenden hebben omtrent een duurzame kust- en zeevisserij op de Noordzee zijn kennis- en innovatievragen verzameld middels het uitvoeren van interviews met de visserijsector, enkele Ngo's en het beleid. In totaal hebben er 10 interviews plaatsgevonden (zie bijlage 1 voor de interviewvragen).

\section{Enquête}

Aanvullend op de interviews is een online enquête uitgezet via social media om zoveel mogelijk stakeholders te bereiken en hen de mogelijkheid te bieden om de kennis- en innovatievragen die zij hebben aan te leveren (zie bijlage 2 voor de enquêtevragen). Zowel in de interviews als in de enquête is ervoor gekozen te werken met de subthema's zoals deze door het Ministerie van LNV zijn gedefinieerd in het missiedocument over kringloop landbouw (Ministerie van LNV, 2019): minder emissies, betere arbeidsomstandigheden, dierenwelzijn, minder bodemberoering, selectiever vissen en het verdienen van een goede boterham. Ook zijn er 2 vragen opgenomen over de Noordzee. De enquête is o.a. verspreid onder vrijwilligers, studenten, vissers en visserijgemeenschappen, Ngo's en onderzoekers. De enquête is 81 keer ingevuld.

Respondenten bestond grotendeels uit vissers, onderzoekers, Ngo's, consultants, duikers/vrijwilligers, personen werkzaam bij de overheid en studenten. De categorieën waren niet wederzijds exclusief, dat wil zeggen dat een respondent meerdere opties (vb. visser én vrijwilliger) kon selecteren. Van de 81 respondenten was meer dan de helft betrokken bij de visserij (42 respondenten; visser, ex-visser, vishandelaar, visserijorganisatie). Ongeveer een kwart was een onderzoeker (19 respondenten), hetzij als medewerker van Wageningen University \& Research, hetzij afkomstig van een ander instituut. Andere respondentengroepen waren Ngo's / consultants (13 respondenten), studenten ( 7 respondenten), overheid medewerkers (7 respondenten), duikers, vrijwilligers en burgers (10 respondenten).

De enquête leidde tot een groot aantal kennis- en innovatievragen, die, indien sprake was van soortgelijke vragen, vervolgens zijn geclusterd.

De verschillende bronnen (literatuur, enquête, interviews) hebben geleid tot een overzicht van meer dan 240 kennis- en innovatievragen voor de studies Noordzee, Visserij en Biogrondstoffen (uit de blauwe ruimte) die samengevoegd zijn in een spreadsheet. In deze spreadsheet kan per kennis- en innovatievraag bekeken worden hoe de vraag gerelateerd is aan specifieke onderwerpen (o.a. ecosysteem, wind op zee, maricultuur, etc.); thema's uit de Kennisagenda Noordzee 2030 (Blauwe economie, duurzame voedselvoorziening, energietransitie en robuuste natuur) en lopende activiteiten. Daarnaast wordt per kennis- en innovatievraag aangegeven of de betreffende vraag onderdeel is van lopend of afgerond onderzoek, of de vraag een witte vlek (volledig of gedeeltelijk) betreft en welke financieringsmogelijkheden voor het invullen van de witte vlekken in aanmerking zouden kunnen komen. Voor elk van de verkregen vragen is de spreadsheet ingevuld en door middel van clustering (bijv. naar thema, witte vlek, etc.) is er een analyse op uitgevoerd (zie paragraaf 2.2.2). De spreadsheet is beschikbaar gesteld aan de opdrachtgever. Een overzicht van kennisvragen staat achterin dit rapport (Bijlage $6 \mathrm{t} / \mathrm{m}$ Bijlage 11).

\section{Workshops}

Naast de interviews en enquête is input verzameld via twee workshops. De eerste workshop werd gehouden op 23 april 2019 met (op verzoek van de opdrachtgever) deelnemers uit overheid en kennisinstellingen met een relatie tot Noordzee, Visserij en (blauwe) Biogrondstoffen (met een focus op zeewier). De tweede workshop was gericht op de bredere gemeenschap van belanghebbenden rond deze thema's en vond plaats op 14 mei 2019 tijdens de reguliere bijeenkomst van de 'Community of Practice Multi-Use Noordzee' van het Ministerie van LNV en de Rijksdienst voor Ondernemend Nederland (RVO). De workshops richtten zich beide op het terugkoppelen van de tussentijdse resultaten, het identificeren van ontbrekende vragen en het aanbrengen van prioriteiten. In de tweede workshop werd ook gewerkt aan een aantal kennis- en innovatiecasussen als input voor onderdelen 4 (mogelijke consortia) en 5 (programmeringsadvies) van de programmeringsstudies. De verslagen van de workshops zijn te vinden in respectievelijk Bijlagen 3 en 4. 
Overleg met topsectoren buiten het LWV-domein

Het thema Duurzame en veilige Noordzee is ook onderdeel van de onderzoeksprogrammering van andere ministeries, topsectoren en NWO (in het bijzonder de Nationale wetenschapsagenda). Daarom is gedurende het project diverse malen contact geweest met het Ministerie van IenW en Rijkswaterstaat en met de TKI Wind op Zee en de Topsector Maritiem.

\subsubsection{Aanpak analyse vragen}

Op basis van clustering van de kennis- en innovatievragen, zijn verschillende analyses uitgevoerd. De kennis- en innovatievragen zijn daarvoor uitgewerkt in de Excel spreadsheet door een breed scala aan onderwerpen en vragen in te vullen. Hierbij is de indeling gevolgd zoals in de LNV-beschrijving van de programmeringsstudies. De thema's en subthema's komen uit de Kennisagenda Noordzee 2030. In de Excel spreadsheet is daardoor per kennis/innovatievraag informatie beschikbaar over het onderwerp (heeft vraag relatie met: visserij (en zo ja per type visserij); natuurherstel/ecologie; wind op zee; aquacultuur; klimaat; economische (rentabiliteit); governance), het geografisch gebied, bij welke kennisinstelling hierover kennis aanwezig is, welke financieringsmiddelen er zijn voor toekomstig onderzoek, etc. De uitgewerkte kennis- en innovatievragen zijn met behulp van draaitabellen in Excel zodanig gesorteerd dat antwoord is gegeven op onderstaande analysevragen.

Naast de analyse via de spreadsheet is een 'mind-map' gemaakt, waarin de vragen en de onderwerpen van de vragen in relatie tot elkaar zijn gebracht en gevisualiseerd in het programma VENSIM. Een vraag als 'Wat is het effect van windparken op de visserijsector' is in de 'mind-map' weergegeven met de termen 'windparken' en 'visserijsector' met een pijl die de relatie aangeeft. Op deze manier is te zien over welke onderwerpen de verschillende vragen gaan en welke termen vaak met elkaar in verband worden gebracht.

Omdat de focus ligt op het identificeren van kennis- en innovatievraagstukken die nog niet opgepakt worden onder bestaande programma's of projecten, de zogenaamde witte vlekken, is in de analyse alleen verder gekeken naar die kennis- en innovatievragen die volledig dan wel als gedeeltelijke witte vlek zijn geïdentificeerd. Voor de Noordzee en Visserij gerelateerde kennis- en innovatievragen is daarom gekeken naar:

- $\quad$ het aantal witte vlekken, dan wel volledig of gedeeltelijk (voor Noordzee, inclusief maricultuur, en voor Visserij);

- $\quad$ het clusteren van de kennis- en innovatievragen per subthema (alleen voor Visserij);

- $\quad$ het bepalen of het een kennis-, of een innovatieopgave is of beide (Noordzee en Visserij);

- $\quad$ het bepalen welke financieringsmogelijkheden mogelijk zouden kunnen zijn (Noordzee en Visserij);

- $\quad$ het bepalen van welke vragen een geheel of gedeeltelijk technisch karakter hebben en daarmee niet binnen de LWV-gerichte topsectoren vallen (Noordzee en Visserij). Deze laatste vragen zijn doorgegeven aan de Topsector Energie en de Topsector Maritiem voor respectievelijk de MMIPs Wind op Zee en Blue Growth.

\subsection{Prioritering kennis- en innovatievragen}

\subsubsection{Workshop 23 april 2019: prioritering en aanpak witte vlekken}

De witte vlekken komen voort uit een uitgebreide inventarisatie van kennis- en innovatievragen rond de thema's energie, voedsel (visserij en maricultuur), overig gebruik en ecosysteem/natuur. Op basis van deze inventarisatie en 'expert judgement' zijn een tiental vragen per studie als prioriteit geïdentificeerd. Vervolgens zijn deze prioriteiten voorgelegd aan de workshop met vertegenwoordigers van overheid en onderzoek op 23 april 2019. Tijdens deze dag zijn ook discussies gevoerd over welke initiatieven geïnitieerd moeten worden om prioritaire thema's aan te pakken en hoe deze gefinancierd zouden kunnen worden. Het verslag van deze workshop is terug te vinden in Bijlage 3. 
Voor de programmeringsstudie Biogrondstoffen zijn tijdens deze workshop geen kennis- of innovatievragen geprioriteerd, maar zijn kennisleegtes opgevuld met het bedenken van nieuwe vragen. Een uitgebreide beschrijving van deze programmeringsstudie is te vinden in de rapportage Programmeringsstudie Biogrondstoffen.

\subsubsection{MMIPs}

De analyses van de kennis- en innovatievragen inclusief de input tijdens de workshop op 23 mei 2019 zijn gebruikt om concept-MMIPs (Meerjarige Missiegedreven Innovatieprogramma's) op te stellen voor Duurzame Noordzee (Missie E), Visserij (Missie E) en Zeewier (Missie B).

Het MMIP Duurzame Noordzee richt zich op het realiseren van duurzaam sociaaleconomisch gebruik van de Noordzee, tegelijkertijd met versterking en waarborging van de ecologische veerkracht van het Noordzee ecosysteem. Daarbij wordt meer inzicht verkregen over de ecologische veerkracht en de ecosysteemrandvoorwaarden die de grenzen van de veerkracht, omslagpunten en de sociaaleconomische gebruiksruimte van de Noordzee bepalen. De focus ligt daarbij op medegebruik van hernieuwbare energie, infrastructuur voor natuur en voedselproductie.

Het MMIP Visserij richt zich op het ontwikkelen van een ecologisch én socio-economisch duurzame kust- en zeevisserij op de Noordzee ter bevordering van een dynamische visserijsector, een goede levensstandaard voor visserijgemeenschappen en een goede status van de visbestanden en het mariene milieu.

Het MMIP Biogrondstoffen richt zich op het innovatietraject dat nodig is voor een grootschalige, rendabele én duurzame zeewierteelt op de Noordzee vanaf 2030 in combinatie met windmolenparken.

De MMIPs Duurzame Noordzee, Visserij en Biogrondstoffen uit de Blauwe Ruimte vormen een samenhangend geheel.

De concept-MMIPs zijn op 1 mei 2019 naar het Ministerie van LNV en de topsector Agri \& Food gestuurd. Hierop is geen feedback ontvangen. De concept-MMIPs zijn vervolgens voorgelegd aan een tweede workshop op 14 mei (zie volgende paragraaf). De bewuste concept-MMIPs (met gestickerde prioritering uit de workshop) zijn te vinden in het verslag van deze workshop in Bijlage 4. De input op de concept-MMIPs uit deze workshop is verwerkt in het eindconcept die 1 juni 2019 opgeleverd zijn aan de Topsector Agri \& Food. Deze eindconcepten, die te vinden zijn in Bijlagen 12, 13 en 14, zijn opgenomen in de 95\%-versie van de Kennis- en Innovatie Agenda LWV (LNV, 2019) en door de topsector opengesteld voor publieke consultatie (https://topsectoragrifood.nl/nieuws/95-versiekennis-en-innovatieagenda-landbouw-water-voedsel-beschikbaar/).

\subsubsection{Workshop 14 mei 2019: Inhoud geven aan kennis- en innovatie}

De tweede workshop met een bredere groep belanghebbenden op 14 mei 2019 richtte zich op het krijgen van verder input voor de Programmeringsstudies en de MMIPs. De input van de stakeholders werd gezocht via 3 opdrachten:
1. burengesprek;
2. stickeren van prioriteiten op de concept-MMIPs;
3. werksessies rond innovatiecasussen.

In het burengesprek kregen de deelnemers de opdracht om in 5 minuten de volgende vraag te beantwoorden: "Als jullie een subsidie van 2 miljoen euro zouden krijgen voor het beantwoorden van één kennisvraag of voor het uitvoeren van één innovatieproject op de Noordzee, waar zouden jullie dat geld dan aan uitgeven?". Het burengesprek was bedoeld om kennis- en innovatievragen die nog niet in het overzicht in de spreadsheet waren opgenomen, te identificeren. Dit leidde tot 6 aanvullende vragen.

Gedurende de dag werd de mogelijkheid geboden om prioriteiten aan te geven op posters op de thema's zoals die op dat moment in de concept-MMIPs (zie paragraaf 2.3.2) voor Noordzee (exclusief 
visserij en maricultuur), Visserij en Biogrondstoffen (onderdeel zeewier) waren opgenomen. De resultaten zijn weergegeven in het verslag van deze bijeenkomst in Bijlage 4.

In de middag werd er in twee rondes in groepen gewerkt aan een kennis- of innovatiecase. De bedoeling was om inzicht te krijgen wat de deelnemers dachten nodig te hebben om iedere casus te realiseren en welke rol zij zelf hierin kunnen spelen. Na een twee minuten pitch van vier cases die allemaal een relatie met de concept-MMIPs hadden, konden de deelnemers zelf kiezen met welke van de volgende cases ze aan de slag wilden.

1. Kennisproject: draagkracht Noordzee;

2. Kennis-/ innovatieproject: ontwikkeling nieuwe onderwatermonitoring technieken voor natuur in een windpark

3. Innovatieproject: natuurherstel en maricultuur in een windpark;

4. Innovatieproject: de zero impact viskotter.

Het verslag van de bijeenkomst is te vinden in Bijlage 4. De input is gebruikt in de uitwerking van de programmeringsstudies en de definitieve MMIPs.

\subsubsection{Afstemming topsectoren buiten het LWV-domein}

Vanuit de Programmeringsstudies Duurzame Noordzee, Visserij en Biogrondstoffen (onderdeel blauwe ruimte) is input geleverd op de concept-MMIPs Wind op Zee (TKI Wind op Zee) en Blue Growth (topsector Maritiem) via deelname aan de consultatiebijeenkomsten. De concept-MMIPs Duurzame Noordzee, Visserij en Zeewier zijn voorgelegd aan de TKI Wind op Zee en Maritiem en input hierop is verwerkt in de voorliggende rapportage en de definitieve MMIPs. Alle kennis- en innovatievragen rond Noordzee, Visserij en Biogrondstoffen (blauwe ruimte) die een puur technisch karakter hebben, zijn doorgeven aan de relevante topsectoren.

Het team Programmeringsstudie Noordzee heeft aan TKI Wind op Zee voorgesteld om een bijeenkomst te organiseren waarin de concept-MMIPs van de LWV-topsectoren rond de thema's Duurzame Noordzee, Visserij, Biogrondstoffen uit de Blauwe Ruimte en de concept-MMIPs van de topsectoren buiten het LWV-domein Blue Growth (inclusief veilige Noordzee), Wind op Zee en Deltatechnologie naast elkaar worden gelegd. Het doel is om doublures of tegenstrijdigheden te voorkomen en te kijken hoe de verschillende MMIPs en financieringsprogramma's elkaar kunnen versterken. Dit initiatief wordt verder opgepakt door de TKI Wind op Zee.

Eind juni is na overleg met het thema Blue Growth is thema 'circulaire visserij' aan de programmeringsstudie Visserij toegevoegd. In deze achtergrondstudie wordt aan het thema 'circulaire visserij' verder geen tekst gewijd, omdat dit buiten de programmeringsstudie Visserij om uitgewerkt is.

\subsection{Beschikbare financieringsmogelijkheden}

Bij het opstellen van deze Programmeringsstudies hoort ook een overzicht van mogelijke financieringsmogelijkheden voor te verrichten onderzoek. Hiervoor zijn verschillende bronnen gebruikt. Ten eerste is gebruik gemaakt van expertise van de acquisiteurs binnen WUR en Deltares. Daarnaast is de bijlage van de Noordzeestrategie 2030 (Noordzee 2030) geraadpleegd (Ministeries van IenW en van LNV, 2018). Deze is geschreven door Henk Merkus (22 oktober 2018) en beschrijft een aantal relevante financieringstrajecten. Als laatste is de website van Rijksdienst voor Ondernemend Nederland (RVO) geconsulteerd (RVO, 2019). Deze bronnen zijn gebruikt om een overzicht te creëren van mogelijke financieringsbronnen voor de kennis- en innovatievragen die een (gedeeltelijke) witte vlek omvatten. De financieringsmogelijkheden zijn beknopt weergegeven in Hoofdstuk 3 Financieringsmogelijkheden. Voor een uitgebreid overzicht, zie de PowerPoint presentatie in Bijlage 5. 


\section{Financieringsmogelijkheden}

\subsection{Algemeen}

Er zijn verschillende soorten mogelijkheden voor het financieren van de witte vlekken. Belangrijk daarbij is dat in het achterhoofd gehouden wordt voor welk soort instituut de financiering is. Er is namelijk een wezenlijk verschil tussen TO2- en NWO-instituten. De Toegepast Onderzoek Organisaties (TO2)-instituten (Wageningen Research, Deltares, Marin, TNO) hebben geen vaste financieringsstroom (eerste geldstroom) waarmee de gebouwen en personele kosten gedekt zijn. Vanuit de Ministeries van Landbouw, Natuur en Voedselkwaliteit (LNV) en Infrastructuur en Waterstaat (IenW) is er voor de TO2-instituten een kennisontwikkelingsfinanciering (opbouwen van kennis) en vanuit het Ministerie van LNV is er een programmeringsfinanciering (uitvoeren van beleidsondersteunend onderzoek). De NWO-instituten (universiteiten) ontvangen een basisfinanciering vanuit NWO en daarmee wordt al een deel van de gemaakte kosten gedekt.

\subsection{Subsidies}

In deze rapportage zijn de subsidies opgedeeld in vijf categorieën:

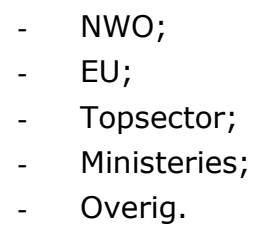

Onder deze categorieën is een aantal relevante subsidies uitgelicht. De toegang voor de verschillende kennisinstellingen (academisch, TO2) verschilt per regeling, evenals het gedekte percentage van de tarieven van de TO2-instiuten. Tabel 1 geeft een kort overzicht. Een uitgebreid overzicht van de financieringsmogelijkheden in de vorm van een PowerPoint is te vinden in Bijlage 5. De digitale PowerPoint is ter beschikking gesteld aan de opdrachtgever.

\subsubsection{NWO}

In principe betaalt NWO alleen aan universiteiten en kennisinstellingen met een eerste geldstroom (bijv. NIOZ). Het is gericht op het financieren van met name promovendi en postdocs. Voor TO2instellingen is NWO-subsidie meestal ongunstig. De regel is dat TO2-instituten niet rechtstreeks aanvrager kunnen zijn. Ze kunnen dus enkel als onderaannemer bijdragen. Kosten van bestaand personeel worden doorgaans niet vergoed. Binnen NWO zijn zeer uiteenlopende programma's en onderwerpen met verschillende financieringsmogelijkheden en -voorwaarden. Daar waar ministeries specifieke programma's financieren en via NWO uitzetten, zijn over het algemeen de voorwaarden voor TO2 instituten iets gunstiger, maar bij lange na nog niet kostendekkend.

\subsubsection{EU}

Binnen de EU zijn verschillende onderzoeksprogramma's, raamcontracten en tenders met elk hun eigenlijk voorwaarden. Het kunnen uiteenlopende programma's en onderwerpen zijn. Hier kunnen TO2-instituten ook aan deelnemen, al zijn niet alle programma's even gunstig als het gaat om de dekking van de kosten. 


\subsubsection{Topsectoren}

De topsectoren betreffen Publiek-Private Samenwerkingsverbanden (PPS-en) waarbij zowel het bedrijfsleven als de publieke sector betrokken is. Dit is interessant voor TO2-instituten. De topsectoren LWV zijn met name relevant voor Wageningen Research omdat $50 \%$ van de financiering van de projecten door de overheid wordt verleend in de vorm van capaciteit van Wageningen Research. Er is een bedrag geserveerd voor financiering van andere TO2-instituten en academische kennisinstellingen, indien hun deelname noodzakelijk is voor het project.

\subsubsection{Ministeries}

De Ministeries van LNV en IenW hebben eigen middelen die ze kunnen inzetten voor onderzoek naar de Noordzee. Dit is een belangrijke financieringsbron voor de TO2-instituten Wageningen Marine Research en Deltares.

\subsubsection{Overig}

Onder 'Overig' vallen subsidies zoals het Waddenfonds en charitatieve fondsen. De voorwaarden kunnen erg uiteenlopen.

Tabel 1. Samenvattend overzicht belangrijkste subsidieregelingen voor Noordzee en Visserij, inclusief toegang voor de verschillende soorten kennisinstellingen en dekking van de tarieven van TO2-instituten. *) bruto salariskosten inclusief werkgeverslasten; IKS = Interne Kostprijs.

\begin{tabular}{|c|c|c|}
\hline Regeling & Toegestaan tarief & $\begin{array}{l}\text { Gedekt percentage van } \\
\text { IKS }\end{array}$ \\
\hline NWO Visserij innovatie fonds & Via NWO, waarschijnlijk HOT tarief 2017 & Nog onbekend \\
\hline NWO NWA & HOT tarief 2017 & $60-70 \%$ \\
\hline NWO Cross-over & Niet toegankelijk voor TO2's & n.v.t. \\
\hline NWA-ORC & HOT tarief 2017 & $60-70 \%$ \\
\hline NWO Groen III & TO2 niet als hoofdaanvrager & n.v.t. \\
\hline EU Eurostars2 & Salariskosten*) $+7 \%$ indirect (?) & Ca. $40 \%$ \\
\hline EU EFRO & RvO IKS & $100 \%$ \\
\hline EU EFMZV & $\begin{array}{l}\text { Regelingen Innovatie in de visserij en } \\
\text { Rendementsverbetering: alleen mogelijk als } \\
\text { onderaannemer, standaardtarief (100\%) } \\
\text { Partnerschapsproject: als consortiumdeelnemer, } \\
\text { IKS-tarief }\end{array}$ & $100 \%$ \\
\hline EU INTERREG & Salariskosten*) $+15 \%$ indirect & $40-50 \%$ \\
\hline EU BANOS & Via NWO & onbekend \\
\hline EU H2020 + EUROPE & Salariskosten $*)+25 \%$ indirect & Ca. $50 \%$ \\
\hline EU LIFE & Salariskosten $*)+7 \%$ indirect & $\begin{array}{l}\text { Ca. } 40 \% \text { ( } 55-70 \% \\
\text { subsidieprogramma } \\
\text { afhankelijk) }\end{array}$ \\
\hline EU tenders + framework contract & Afhankelijk van bieding & Afhankelijk van bieding \\
\hline EU COST & n.v.t. & n.v.t. \\
\hline Topsectoren + NWO & RvO IKS afgetopt tot $125,00 /$ uur & Gemiddeld ca. $70 \%$ \\
\hline Topsectoren TKI & RvO topsectoren tarief (LNV-tarief $+20 \%$ opslag) & $100 \%$ \\
\hline Ministeries missie programma & Onbekend & Onbekend \\
\hline Ministeries WOZEP & RvO IKS & $100 \%$ \\
\hline Ministeries KPP & RvO IKS+ & $100 \%$ \\
\hline Ministeries FDW & Salariskosten $*)+50 \%$ indirect & $50-60 \%$ \\
\hline Waddenfonds & Salariskosten $*)+20 \%$ indirect & Ca. $45 \%$ \\
\hline
\end{tabular}




\section{$4 \quad$ Uitgebreide resultaten Programmeringsstudie Duurzame Noordzee}

\subsection{Inleiding}

Dit hoofdstuk bevat de uitgebreide resultaten van de analyse voor de Programmeringsstudie Duurzame Noordzee (exclusief visserij). De Programmeringsstudie Noordzee (Steins et al., 2019) richt zich op de maatschappelijke opgave van een Duurzame Noordzee. Het thema 'veiligheid', dat ook onderdeel uitmaakt van de missie die door het kabinet voor de Noordzee is vastgesteld, maakt daarmee geen deel uit van deze Programmeringsstudie. De belangrijke gebruiksfunctie, visserij, is niet meegenomen, maar wordt behandeld in de Programmeringsstudie Visserij (Smith et al., 2019). De andere gebruiksfunctie rond voedsel in de vorm van maricultuur (bijv. zeewier- en schelpdierkweek) is voor een deel ook meegenomen de Programmeringsstudie Biogrondstoffen en in het betreffende aparte rapport opgenomen (Elbersen et al., 2019). Daar waar het gaat om meervoudig ruimtegebruik van bijvoorbeeld windenergie en visserij en/of maricultures is dit opgenomen in de Programmeringsstudie Duurzame Noordzee (Steins et al. 2019).

\subsection{Maatschappelijke opgave}

De maatschappelijke opgave staat uitgebreid beschreven in de Programmeringsstudie Duurzame Noordzee (Steins et al., 2019). Omwille van de duidelijkheid worden de missie (Tabel 2) en ambities (Tabel 3) van het ministerie van LNV voor de Noordzee hieronder herhaald.

Tabel 2. Kennis en Innovatie Agenda LNV (2019-2030), missie Noordzee Missie E. Duurzame Landbouw en veilige Noordzee, oceanen en binnenwateren

Voor de mariene wateren is er in 2030 en voor rivieren, meren en estuaria in 2050 een balans tussen enerzijds ecologische draagkracht en waterbeheer (waterveiligheid, zoetwatervoorziening en waterkwaliteit) en anderzijds de opgaven voor hernieuwbare energie, voedsel, visserij en andere economische activiteiten.

Bron: Ministerie van LNV (2019).

Tabel 3. Ambities en innovatieopgaven voor een Duurzame Noordzee

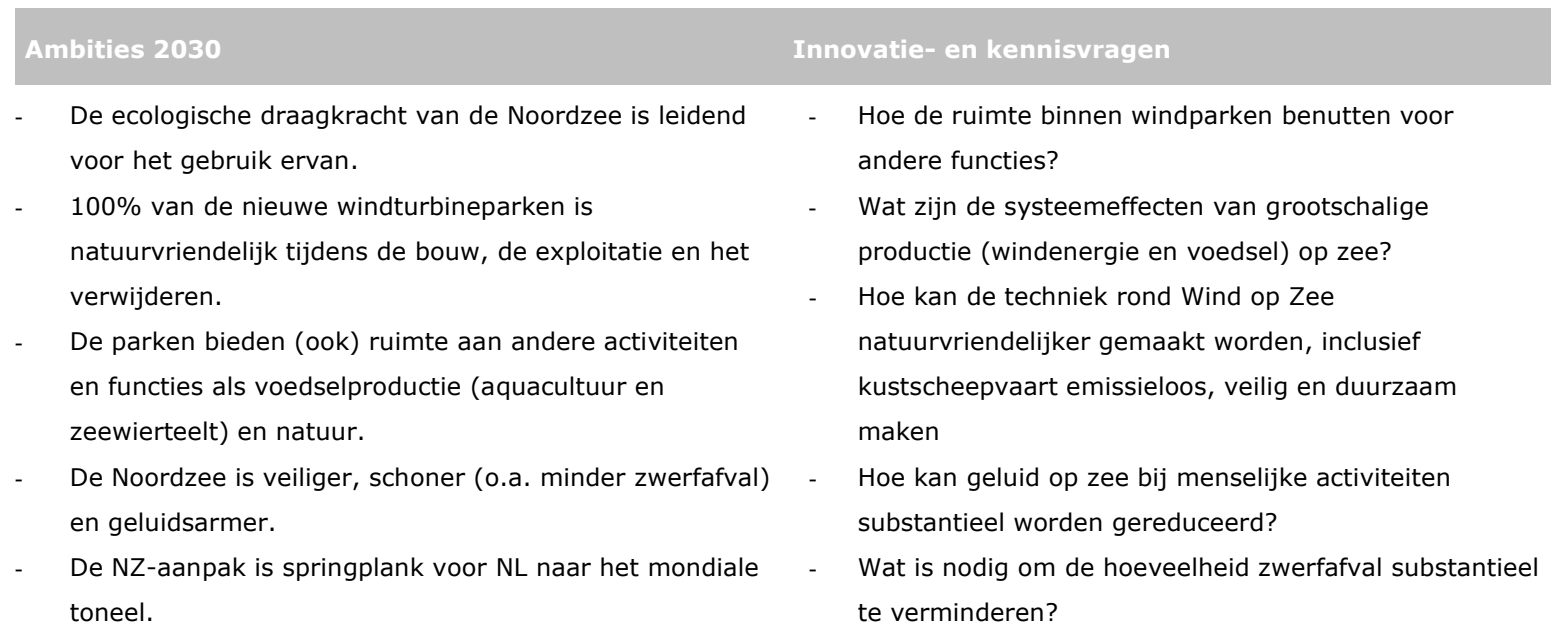


Hoe kan een volwaardige zeewierketen tot stand worden gebracht die zichzelf economisch in stand houdt?

Het ontwikkelen van slimme systemen voor monitoring van de ecologische toestand en het waterbeheer? Welke alternatieve vormen van energie zijn mogelijk op zee mocht wind op zee vastlopen door een cumulatie van effecten op de ecologie of ruimtegebrek?

Bron: Ministerie van LNV (2019)

\subsection{Lopend onderzoek}

Een beschrijving van het lopende Noordzee onderzoek is te vinden in de Programmeringsstudie Duurzame Noordzee (Steins et al., 2019).

\subsection{Witte vlekken}

\subsubsection{Mind-map kennis- en innovatievragen}

\section{Noordzee}

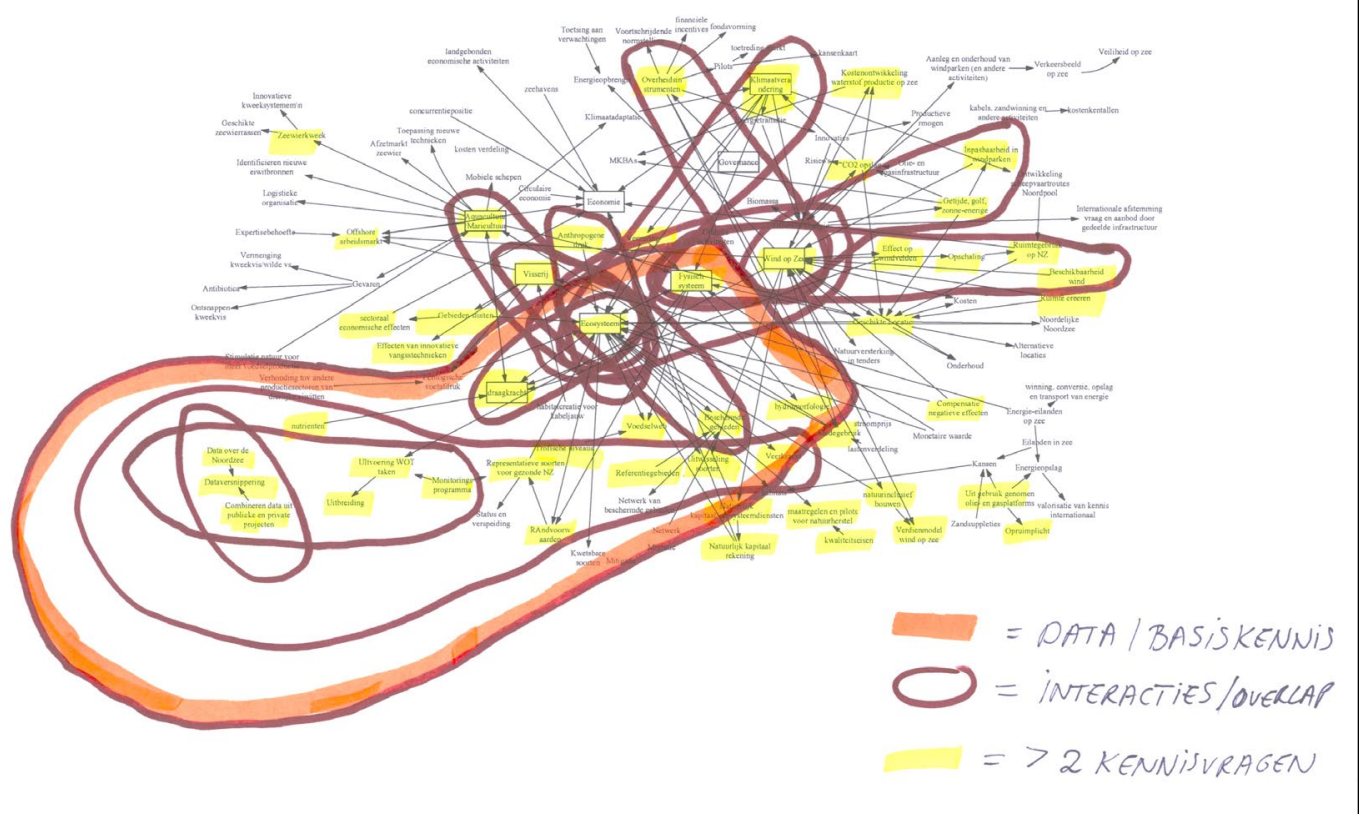

Figuur 1. 'Mind-map' Noordzee (exclusief visserij).

Op basis van de primaire en secundaire bronnen zoals beschreven in Hoofdstuk 2 zijn in totaal meer dan 120 Noordzee-gerelateerde kennis- en innovatievragen geïdentificeerd. Deze zijn gecategoriseerd rond een aantal onderwerpen. In alfabetische volgorde zijn dit: economie, ecosysteem, energie (anders dan wind op zee), governance, klimaat, maricultuur, meervoudig ruimtegebruik, natuur (bescherming, herstel en ontwikkeling), waterveiligheid (kustbescherming, zandwinning) en wind op zee. De vragen zijn geclusterd over deze onderwerpen en vervolgens is een mind-map gemaakt, die de onderlinge relaties tussen de onderwerpen in de vragen laat zien. Vervolgens is gekeken welke vragen meer dan twee keer voorkwamen en zijn de onderlinge relaties of interacties ingetekend; ook 
is aangegeven wanneer clusters basisdata/monitoring betreffen. De mind-map is weergegeven in Figuur 1 . Het is duidelijk dat er sprake is van een grote complexiteit en overlap.

In de witte vlekken analyse zijn vervolgens de meest 'centrale' onderwerpen uit de 'mind-map' verder uitgewerkt: Wind op Zee in relatie tot Ecosysteem, Natuur en Meervoudig Ruimtegebruik; Energie (anders dan wind op zee) in relatie tot Ecosysteem, Natuur en Meervoudig Ruimtegebruik; en het onderwerp Maricultuur.

\subsubsection{Witte vlekken analyse kennis - en innovatievragen (excl. visserij)}

Van de 122 Noordzee-gerelateerde kennis- en innovatievragen zijn 116 vragen een witte vlek en van 3 vragen is het onbekend. Dit betekent dat de resterende 3 kennis- en innovatievragen blinde vlekken betreft. Dit betekent dat deze vragen al wel zijn onderzocht, maar dat de betreffende stakeholders niet bekend zijn met de uitkomsten van het onderzoek. De als witte vlekken geïdentificeerde vragen zijn op te delen in 76 volledige witte vlekken en 40 gedeeltelijk witte vlekken (Figuur 2).

WITTE VLEKKEN KENNIS- EN INNOVATIEVRAGEN NOORDZEE (EX. VISSERIJ)

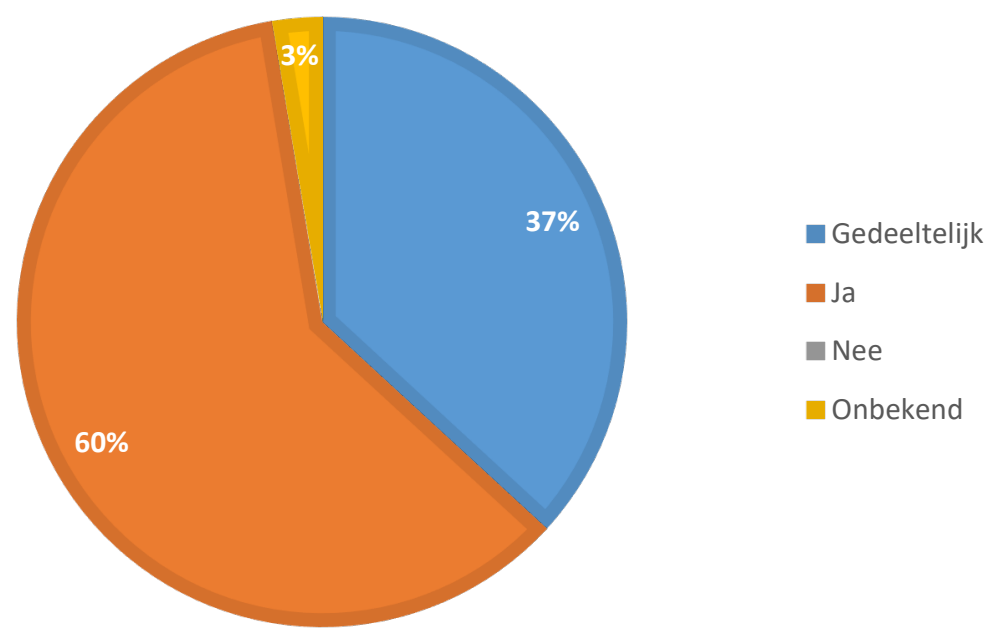

Figuur 2. Status kennis- en innovatievragen (excl. visserij). Totaal: 116.

De 116 witte vlekken zijn onder te verdelen in 93 kennisopgaves en 15 innovatieopgaves. Negen zijn een gecombineerde kennis- en innovatieopgave. De 2 resterende vragen hebben het label Onbekend gekregen omdat zij in een andere categorie vielen (bijv. een beleidsvraag).

In het ingediende Nationale Wetenschapsagenda voorstel 'North Sea in Transition' (NWA-NSiT) werden 69 van de 116 witte vlekken geadresseerd. Met de gunning van het voorstel zou binnen een periode van 4 tot 5 jaar een groot deel van de kennislacunes in relatie tot de effecten van de uitbouw van grootschalige wind op zee zijn ingevuld. Gezien het belang van dit onderzoek hadden diverse ministeries de benodigde cofinanciering toegezegd. Op 3 juni 2019 werd de consortiumleider geïnformeerd dat het voorstel niet is gehonoreerd.

De witte vlekken kunnen worden verdeeld over verschillende onderwerpen. In alfabetische volgorde zijn dit: economie, ecosysteem, energie (anders dan wind op zee), governance, klimaat, maricultuur, meervoudig ruimtegebruik, natuur (bescherming, herstel en ontwikkeling), waterveiligheid (kustbescherming, zandwinning) en wind op zee. Tabel 4 geeft een overzicht van het aantal witte vlekken (geheel, gedeeltelijk, geen witte vlek, onbekend). Voor de witte vlekken is aangegeven of het een kennis- of innovatieopgave is of een combinatie ervan (5). 
Tabel 4. Overzicht witte vlekken rond Noordzee-onderwerpen. Getallen geven het aantal kennis/innovatievragen aan per type witte vlek (geheel, gedeeltelijk, geen witte vlek, onbekend).

\begin{tabular}{|c|c|c|c|c|}
\hline Onderwerp & Geheel & Gedeeltelijk & Geen & Onbekend \\
\hline Economie & 32 & 7 & 0 & 2 \\
\hline Energie & 21 & 6 & 1 & 3 \\
\hline Ecosysteem & 36 & 21 & 3 & 1 \\
\hline Governance & 26 & 9 & 1 & 1 \\
\hline Klimaat & 10 & 4 & 0 & 0 \\
\hline Maricultuur & 23 & 13 & 3 & 2 \\
\hline Meervoudig ruimtegebruik & 22 & 15 & 3 & 0 \\
\hline Natuur & 30 & 21 & 3 & 0 \\
\hline Waterveiligheid & 5 & 1 & 1 & 0 \\
\hline Wind op Zee & 24 & 13 & 3 & 2 \\
\hline
\end{tabular}

Tabel 5. Aantal kennisvragen met een witte vlek per subthema met een onderverdeling tussen een Kennisopgave, een Innovatie opgave of beiden.

\begin{tabular}{|c|c|c|c|c|}
\hline Onderwerp & Kennisopgave & $\begin{array}{c}\text { Innovatie- } \\
\text { opgave }\end{array}$ & $\begin{array}{c}\text { Kennis- en } \\
\text { innovatie- } \\
\text { opgave }\end{array}$ & Onbekend \\
\hline Economie & 33 & 2 & 4 & 0 \\
\hline Energie & 21 & 4 & 1 & 1 \\
\hline Ecosysteem & 56 & 1 & 0 & 0 \\
\hline Governance & 28 & 3 & 3 & 1 \\
\hline Klimaat & 14 & 0 & 0 & 0 \\
\hline Maricultuur & 23 & 6 & 7 & 0 \\
\hline Meervoudig ruimtegebruik & 29 & 4 & 3 & 1 \\
\hline Natuur & 48 & 0 & 3 & 0 \\
\hline Waterveiligheid & 6 & 0 & 0 & 0 \\
\hline Wind op Zee & 31 & 5 & 0 & 1 \\
\hline
\end{tabular}

De witte vlekken onderwerpen "(Eco)systeemeffecten van grootschalige productie (wind en voedsel) op zee" en "Hoe de ruimte binnen windparken te benutten voor andere functies) waren ook de 2 belangrijkste kennisvragen in de prioriteitenlijst voor de Noordzee in de online enquête.

Respectievelijk 32 en 18 keer werden onderwerpen benoemd door de 54 respondenten die deze vraag invulden. De minst belangrijke kennisvragen volgens deze respondenten waren: "Hoe kan een zeewierketen tot stand worden gebracht die zichzelf economisch in stand houdt"(25x) en "Welke alternatieve vormen van energie zijn mogelijk op zee mocht het wind op zee project vastlopen door een cumulatie van effecten op de ecologie of ruimtegebrek? (19x).

4.4.2.1 Witte vlekken: Wind op zee

Uit de analyse van de onderwerpen met witte vlekken blijkt dat de energietransitie een grote focus kent. Onderstaande tabellen geven een overzicht van de onderwerpen Wind op Zee en Energie, anders dan wind. Hierbij is voor beide onderwerpen de relatie in kaart gebracht voor ieder van de onderwerpen Ecosysteem, Natuur, Klimaat en Meervoudig Ruimtegebruik.

Er zijn in totaal 37 kennisvragen exclusief visserij over het onderwerp Wind op Zee waarvan er:

- 14 een relatie met het onderwerp Economie hebben ( 3 een gedeeltelijke en 11 een volledige witte vlek);

- 15 een relatie met het onderwerp Energie, anders dan Wind op Zee hebben (5 een gedeeltelijke en 10 een volledige witte vlek);

- 20 een relatie met het onderwerp Ecosysteem hebben ( 8 een gedeeltelijke en 12 een volledige witte vlek);

- 14 een relatie met het onderwerp Governance hebben ( 3 een gedeeltelijke en 11 een volledige witte vlek);

- 3 een relatie met het onderwerp Klimaat hebben (alle 3 een volledige witte vlek);

- 3 een relatie met het onderwerp Maricultuur hebben (alle 3 een volledige witte vlek);

- 24 een relatie met het onderwerp Meervoudig Ruimtegebruik hebben (11 een gedeeltelijke en 13 een volledige witte vlek); 
- 20 een relatie met het onderwerp Natuur hebben ( 8 een gedeeltelijke en 12 een volledige witte vlek);

- 3 een relatie met het onderwerp Waterveiligheid hebben (alle 3 een volledige witte vlek).

Voor het thema Wind op Zee in relatie met de onderwerpen Ecosysteem, Natuur en Meervoudig Ruimtegebruik geven onderstaande tabellen een nadere uitwerking. De onderwerpen Ecosysteem en Natuur zijn daarbij in een aantal subcategorieën uitgewerkt.

\section{Wind op Zee in relatie tot Ecosysteem}

Er zijn in totaal 37 kennisvragen exclusief visserij over het onderwerp Wind op Zee waarvan er 20 een relatie met het onderwerp Ecosysteem hebben (Tabel 6). Hiervan hebben er 8 een gedeeltelijke witte vlek en 12 een volledige witte vlek. Alle kennisvragen over de onderwerpen wind op zee en ecosysteem zijn kennisopgaven. Van deze vragen waren er 18 opgenomen in het afgewezen NWANSiT voorstel.

Tabel 6. Aantal kennisvragen exclusief visserij over het onderwerp wind op zee en de relatie met het onderwerp ecosysteem. De laatste kolom geeft weer hoeveel vragen binnen de subcategorie in het NWA-NSiT voorstel waren opgenomen.

\begin{tabular}{|c|c|c|c|c|c|c|}
\hline Witte vlek? & $\begin{array}{l}\text { Subthema } \\
\text { ecosysteem }\end{array}$ & $\begin{array}{l}\text { Innovatie } \\
\text {-opgave }\end{array}$ & $\begin{array}{l}\text { Kennis- } \\
\text { opgave }\end{array}$ & $\begin{array}{c}\text { Onbeken } \\
\text { d }\end{array}$ & $\begin{array}{l}\text { Eind- } \\
\text { totaal }\end{array}$ & $\begin{array}{l}\text { NWA- } \\
\text { NSIT }\end{array}$ \\
\hline Gedeeltelijk & $\begin{array}{l}\text { Ecologische } \\
\text { (randvoor)waarden }\end{array}$ & 0 & 4 & 0 & 4 & 4 \\
\hline Gedeeltelijk & Effect/impact/risico & 0 & 1 & 0 & 1 & 1 \\
\hline Gedeeltelijk & Natuurherstel & 0 & 2 & 0 & 2 & 1 \\
\hline Gedeeltelijk & Ja (algemeen) & 0 & 1 & 0 & 1 & 0 \\
\hline $\mathrm{Ja}$ & Ecosysteemdiensten & 0 & 1 & 0 & 1 & 1 \\
\hline $\mathrm{Ja}$ & Effect/impact/risico & 0 & 4 & 0 & 4 & 4 \\
\hline $\mathrm{Ja}$ & Natuurherstel & 0 & 4 & 0 & 4 & 4 \\
\hline \multirow[t]{2}{*}{$\mathrm{Ja}$} & Ja (algemeen) & 0 & 0 & 0 & 0 & 0 \\
\hline & Eindtotaal & $\mathbf{0}$ & 20 & $\mathbf{0}$ & 20 & 18 \\
\hline
\end{tabular}

Bijlage 6 geeft een overzicht van de verschillende kennis- en innovatievragen over het onderwerp Wind op Zee en de relatie met het onderwerp Ecosysteem. Een onderverdeling wordt gemaakt tussen gedeeltelijke en volledige witte vlekken. Per kennisvraag wordt aangegeven of het een kennis-, een innovatieopgave of beiden is.

Wind op Zee in relatie tot Natuur

Er zijn in totaal 37 kennisvragen exclusief visserij over het onderwerp Wind op Zee waarvan er 20 een relatie met het onderwerp natuur hebben (Tabel 7). Van de kennisvragen exclusief visserij over het onderwerp wind op zee en een relatie met het onderwerp natuur hebben er 8 een gedeeltelijke witte vlek en 12 een volledige witte vlek. Alle kennisvragen over de onderwerpen Wind op Zee en Natuur zijn kennisopgaven. Van deze vragen waren er 17 opgenomen in het afgewezen NWA-NSiT voorstel.

Tabel 7. Aantal kennisvragen exclusief visserij over het onderwerp wind op zee en het onderwerp natuur. De laatste kolom geeft weer hoeveel vragen binnen de subcategorie in het NWA-NSiT voorstel waren opgenomen.

\begin{tabular}{|c|c|c|c|c|c|c|}
\hline $\begin{array}{l}\text { Witte } \\
\text { vlek? }\end{array}$ & Natuur? & $\begin{array}{c}\text { Innovatie- } \\
\text { opgave }\end{array}$ & $\begin{array}{l}\text { Kennis- } \\
\text { opgave }\end{array}$ & Onbekend & Eindtotaal & NWA-NSIT \\
\hline Gedeeltelijk & $\mathrm{Ja}$ & 0 & 8 & 0 & 8 & 5 \\
\hline \multirow[t]{2}{*}{$\mathrm{Ja}$} & $\mathrm{Ja}$ & 0 & 12 & 0 & 12 & 12 \\
\hline & Eindtotaal & $\mathbf{0}$ & 20 & 0 & 20 & 17 \\
\hline
\end{tabular}

Bijlage 6 geeft een overzicht van de verschillende kennis- en innovatievragen over het onderwerp Wind op Zee en de relatie met het onderwerp Natuur. Een onderverdeling wordt gemaakt tussen gedeeltelijke en volledige witte vlekken. Per kennisvraag wordt aangegeven of het een kennis-, een innovatieopgave of beiden is. 
Wind op Zee in relatie tot Meervoudig Ruimtegebruik

Er zijn in totaal 37 kennisvragen exclusief visserij over het onderwerp Wind op Zee, waarvan er 27 een relatie met het onderwerp Meervoudig Ruimtegebruik hebben (Tabel 8). Hiervan hebben er 11 een gedeeltelijke witte vlek en 13 een volledige witte vlek. De meeste kennisvragen over de onderwerpen wind op zee en medegebruik zijn kennisopgaven ( 22 vragen, waarvan 19 met een (gedeeltelijke) witte vlek). Er zijn 4 innovatieopgaven en voor 1 kennisvraag is het onbekend of het om innovatie- en/of kennisopgaven gaat. Van deze witte vlekken vragen waren er 19 opgenomen in het afgewezen NWANSiT voorstel.

Tabel 8. Aantal kennisvragen exclusief visserij over het onderwerp wind op zee en de relatie met het onderwerp meervoudig ruimtegebruik. De laatste kolom geeft weer hoeveel vragen binnen de subcategorie in het NWA-NSiT voorstel waren opgenomen.

\begin{tabular}{|c|c|c|c|c|c|c|}
\hline $\begin{array}{l}\text { Witte } \\
\text { vlek? }\end{array}$ & $\begin{array}{l}\text { Mede- } \\
\text { gebruik? }\end{array}$ & $\begin{array}{c}\text { Innovatie- } \\
\text { opgave }\end{array}$ & $\begin{array}{l}\text { Kennis- } \\
\text { opgave }\end{array}$ & Onbekend & Eindtotaal & NWA-NSIT \\
\hline Gedeeltelijk & Ja & 0 & 10 & 1 & 11 & 8 \\
\hline \multirow[t]{2}{*}{ Nee } & $\mathrm{Ja}$ & 0 & 3 & 0 & 3 & 2 \\
\hline & Eindtotaal & 4 & 22 & 1 & 27 & 21 \\
\hline
\end{tabular}

Bijlage 6 geeft een overzicht van de verschillende kennis- en innovatievragen over het onderwerp Wind op Zee en de relatie met het onderwerp Meervoudig Ruimtegebruik. Een onderverdeling wordt gemaakt tussen gedeeltelijke en volledige witte vlekken. Per kennisvraag wordt aangegeven of het een kennis-, een innovatieopgave of beiden is.

4.4.2.2 Witte vlekken: Energie, anders dan wind op zee Er zijn in totaal 31 kennisvragen exclusief visserij over het onderwerp Energie, anders dan Wind op Zee waarvan er:

- 13 een relatie met het onderwerp Economie hebben ( 1 een gedeeltelijke en 10 een volledige witte vlek);

- 11 een relatie met het onderwerp Ecosysteem hebben ( 3 een gedeeltelijke en 6 een volledige witte vlek);

- 8 een relatie met het onderwerp Governance hebben ( 1 een gedeeltelijke en 6 een volledige witte vlek);

- 2 een relatie met het onderwerp Klimaat hebben (beiden een volledige witte vlek);

- 3 een relatie met het onderwerp Maricultuur hebben ( 0 een gedeeltelijke en 2 een volledige witte vlek);

- 20 een relatie met het onderwerp Meervoudig Ruimtegebruik hebben (5 een gedeeltelijke en 14 een volledige witte vlek);

- 6 een relatie met het onderwerp Natuur hebben ( 1 een gedeeltelijke en 4 een volledige witte vlek);

- 0 een relatie met het onderwerp Waterveiligheid hebben;

- 18 een relatie met het onderwerp Wind op Zee hebben ( 5 een gedeeltelijke en 10 een volledige witte vlek).

Voor het thema Energie, anders dan Wind op Zee in relatie met de onderwerpen Ecosysteem, Natuur en Meervoudig Ruimtegebruik geven onderstaande tabellen een nadere uitwerking. De onderwerpen Ecosysteem en Natuur zijn daarbij in een aantal subcategorieën uitgewerkt.

\section{Energie (anders dan wind) en Ecosysteem}

Er zijn in totaal 31 kennisvragen exclusief visserij over het onderwerp Energie (anders dan wind) waarvan er 11 een relatie met het onderwerp Ecosysteem hebben (Tabel 9). Hiervan hebben er 3 een gedeeltelijke witte vlek en 6 een volledige witte vlek. Alle kennisvragen over de onderwerpen energie (anders dan wind) en ecosysteem zijn kennisopgaven. Van deze witte vlekken vragen waren er 7 opgenomen in het afgewezen NWA-NSiT voorstel. 
Tabel 9. Aantal kennisvragen exclusief visserij over het onderwerp energie (anders dan wind) en de relatie met het onderwerp ecosysteem. De laatste kolom geeft weer hoeveel vragen binnen de subcategorie in het NWA-NSiT voorstel waren opgenomen

\begin{tabular}{|c|c|c|c|c|c|c|}
\hline Witte vlek? & $\begin{array}{l}\text { Subthema } \\
\text { ecosysteem }\end{array}$ & $\begin{array}{l}\text { Innovatie } \\
\text { opgave }\end{array}$ & $\begin{array}{l}\text { Kennis } \\
\text { opgave }\end{array}$ & Onbekend & $\begin{array}{l}\text { Eind- } \\
\text { totaal }\end{array}$ & NWA-NSIT \\
\hline Gedeeltelijk & $\begin{array}{l}\text { Ecologische } \\
\text { (randvoor)waarden }\end{array}$ & 0 & 0 & 0 & 0 & 0 \\
\hline Gedeeltelijk & Effect/impact/risico & 0 & 2 & 0 & 2 & 2 \\
\hline Gedeeltelijk & Natuurherstel & 0 & 1 & 0 & 1 & 1 \\
\hline $\mathrm{Ja}$ & $\begin{array}{l}\text { Ecologische } \\
\text { (randvoor)waarden }\end{array}$ & 0 & 0 & 0 & 0 & 0 \\
\hline $\mathrm{Ja}$ & Effect/impact/risico & 0 & 5 & 0 & 5 & 3 \\
\hline $\mathrm{Ja}$ & Natuurherstel & 0 & 1 & 0 & 1 & 1 \\
\hline Nee & Natuurherstel & 0 & 1 & 0 & 1 & 1 \\
\hline \multirow[t]{2}{*}{ Onbekend } & Ecosysteemdiensten & 0 & 1 & 0 & 1 & 0 \\
\hline & Eindtotaal & $\mathbf{0}$ & 11 & $\mathbf{0}$ & 11 & 8 \\
\hline
\end{tabular}

Bijlage 7 geeft een overzicht van de verschillende kennis- en innovatievragen over het onderwerp Energie (anders dan wind) en de relatie met het onderwerp Ecosysteem. Een onderverdeling wordt gemaakt tussen gedeeltelijke en volledige witte vlekken. Per kennisvraag wordt aangegeven of het een kennis-, een innovatieopgave of beiden is.

\section{Energie (anders dan wind) en Natuur}

Er zijn in totaal 31 kennisvragen exclusief visserij over het onderwerp Energie (anders dan wind) waarvan er 6 een relatie met het onderwerp Natuur hebben (Tabel 10). Hiervan heeft er 1 een gedeeltelijke witte vlek en 4 een volledige witte vlek. Alle kennisvragen met een (gedeeltelijke) witte vlek over de onderwerpen Energie (anders dan wind) en Natuur zijn kennisopgaven. Van deze witte vlekken vragen waren er 3 opgenomen in het afgewezen NWA-NSiT voorstel.

Tabel 10. Aantal kennisvragen exclusief visserij over het onderwerp energie (anders dan wind) en de relatie met het onderwerp natuur. De laatste kolom geeft weer hoeveel vragen binnen de subcategorie in het NWA-NSiT voorstel waren opgenomen.

\begin{tabular}{|c|c|c|c|c|c|c|}
\hline Witte vlek? & Natuur? & $\begin{array}{c}\text { Innovatie } \\
\text { opgave }\end{array}$ & $\begin{array}{l}\text { Kennis } \\
\text { opgave }\end{array}$ & Onbekend & Eindtotaal & NWA-NSIT \\
\hline Gedeeltelijk & $\mathrm{Ja}$ & 0 & 1 & 0 & 1 & 1 \\
\hline $\mathrm{Ja}$ & $\mathrm{Ja}$ & 0 & 4 & 0 & 4 & 2 \\
\hline \multirow[t]{2}{*}{ Nee } & $\mathrm{Ja}$ & 0 & 1 & 0 & 1 & \\
\hline & Eindtotaal & 0 & 6 & 0 & 6 & 3 \\
\hline
\end{tabular}

Bijlage 7 geeft een overzicht van de verschillende kennis- en innovatievragen over het onderwerp Energie (anders dan wind) en de relatie met het onderwerp Natuur. Een onderverdeling wordt gemaakt tussen gedeeltelijke en volledige witte vlekken. Per kennisvraag wordt aangegeven of het een kennis-, een innovatieopgave of beiden is.

\section{Energie (anders dan wind) en Meervoudig Ruimtegebruik}

Er zijn in totaal 31 kennisvragen exclusief visserij over het onderwerp Energie (anders dan wind), waarvan er 20 een relatie met het onderwerp Meervoudig Ruimtegebruik hebben (Tabel 11). Hiervan hebben er 5 een gedeeltelijke witte vlek en 10 een volledige witte vlek. De meeste kennisvragen met een (gedeeltelijke) witte vlek over de onderwerpen Energie (anders dan wind) en Meervoudig Ruimtegebruik zijn kennisopgaven (14 vragen). Er zijn 3 innovatieopgaven en voor 1 kennisvraag is het onbekend of het om innovatie- en/of kennisopgaven gaat. Van deze witte vlekken vragen waren er 15 opgenomen in het afgewezen NWA-NSiT voorstel. 
Tabel 11. Aantal kennisvragen exclusief visserij over het onderwerp energie (anders dan wind) en de relatie met het onderwerp medegebruik. De laatste kolom geeft weer hoeveel vragen binnen de subcategorie in het NWA-NSiT voorstel waren opgenomen.

\begin{tabular}{|c|c|c|c|c|c|c|c|}
\hline Witte vlek? & $\begin{array}{l}\text { Mede- } \\
\text { gebruik? }\end{array}$ & $\begin{array}{c}\text { Innovatie- } \\
\text { opgave }\end{array}$ & $\begin{array}{l}\text { Kennis } \\
\text { opgave }\end{array}$ & $\begin{array}{c}\text { Kennis- } \\
\text { en } \\
\text { innovatie } \\
\text {-opgave }\end{array}$ & Onbekend & $\begin{array}{l}\text { Eind- } \\
\text { totaal }\end{array}$ & $\begin{array}{l}\text { NWA- } \\
\text { NSIT }\end{array}$ \\
\hline Gedeeltelijk & $\mathrm{Ja}$ & 0 & 4 & 0 & 1 & 5 & 5 \\
\hline $\mathrm{Ja}$ & $\mathrm{Ja}$ & 3 & 10 & 1 & 0 & 14 & 10 \\
\hline Nee & $\mathrm{Ja}$ & 0 & 1 & 0 & 0 & 1 & 1 \\
\hline
\end{tabular}

Bijlage 7 geeft een overzicht van de verschillende kennis- en innovatievragen over het onderwerp Energie (anders dan wind) en de relatie met het onderwerp Meervoudig Ruimtegebruik. Een onderverdeling wordt gemaakt tussen gedeeltelijke en volledige witte vlekken. Per kennisvraag wordt aangegeven of het een kennis-, een innovatieopgave of beiden is.

\subsubsection{Witte vlekken: Maricultuur}

Zowel vanuit het Noordzee 2030 proces als het klimaatakkoord ziet men veel potentieel voor de ontwikkeling van maricultuur. Om die reden wordt dit thema kort uitgelicht. Er zijn in totaal 38 kennisvragen exclusief visserij over het onderwerp Maricultuur. Hiervan hebben er 14 een gedeeltelijke witte vlek en 23 een volledige witte vlek (Tabel 12). De meeste kennisvragen met een (gedeeltelijke) witte vlek over de onderwerpen wind op zee en medegebruik zijn kennisopgaven (23 vragen). Er zijn 7 innovatieopgaven en voor 7 kennisvragen gaat het om zowel innovatie- als kennisopgaven. Van de witte vlekken vragen waren er 12 opgenomen in het afgewezen NWA-NSiT voorstel.

Tabel 12. Aantal kennisvragen exclusief visserij over het onderwerp Maricultuur. De laatste kolom geeft weer hoeveel vragen binnen de subcategorie in het NWA-NSiT voorstel waren opgenomen

\begin{tabular}{|c|c|c|c|c|c|c|}
\hline Witte vlek? & $\begin{array}{c}\text { Innovatie } \\
\text { opgave }\end{array}$ & $\begin{array}{l}\text { Kennis } \\
\text { opgave }\end{array}$ & $\begin{array}{c}\text { Kennis- en } \\
\text { innovatie- } \\
\text { opgave }\end{array}$ & Onbekend & Eindtotaal & NWA-NSIT \\
\hline Gedeeltelijk & 4 & 7 & 3 & 0 & 14 & 4 \\
\hline $\mathrm{Ja}$ & 3 & 16 & 4 & 0 & 23 & 8 \\
\hline Onbekend & 0 & 1 & 0 & 0 & 1 & 0 \\
\hline
\end{tabular}

Bijlage 8 geeft een overzicht van de verschillende kennis- en innovatievragen over het onderwerp Maricultuur. Een onderverdeling wordt gemaakt tussen gedeeltelijke en volledige witte vlekken. Per kennisvraag wordt aangegeven of het een kennis-, een innovatieopgave of beiden is.

\subsection{Kennis- en innovatiethema's en prioritaire onderwerpen}

Op basis van de analyse van de witte vlekken rond de kennis- en innovatiethema's voor de Noordzee exclusief visserij kunnen drie centrale thema's worden onderscheiden:

1. Monitoring, modellering, data- en informatiemanagement en afwegingskaders voor menselijk medegebruik binnen de draagkracht van het Noordzee ecosysteem;

2. Natuurvriendelijke aanleg van grootschalige bouwwerken voor energieproductie en stimulering van natuur hierbinnen;

3. Meervoudig ruimtegebruik door combinaties van energie infrastructuur met voedselproductie (visserij en maricultuur).

Daarnaast is er een vierde thema dat binnen de ambities van de vastgestelde missie rond Duurzame Noordzee, Oceanen en Binnenwateren valt, maar dat in de inventarisatie van de kennis- en innovatievragen weinig prominent was: Vermindering van afval in zee. Dit thema werd echter wel in de 
prioriteringssessies met stakeholders benoemd als een prioritair onderwerp. Om deze redenen wordt dit thema als vierde centrale thema toegevoegd.

Op basis van de stakeholder workshops en de online enquête liggen binnen de bovengenoemde deelprogramma's de prioriteiten bij:

- $\quad$ kennisontwikkeling over de omvang van zogenaamde 'zog-effecten' van wind op zee en stratificatie-effecten en hoe deze doorwerken op het ecosysteem ${ }^{1}$;

- $\quad$ versterken van de kennisbasis over de gevolgen van klimaatverandering voor de zeespiegelstijging in 2100 (inzet Noordzee hulpbronnen voor kustverdediging) en het ecosysteem en gebruiksfuncties;

- fundamentele en toegepaste kennisontwikkeling over inzet van innovatieve (remote), praktisch uitvoerbare monitoringstechnieken;

- $\quad$ ontwikkeling van risicobeoordeling van cumulatieve effecten van menselijk gebruik; (e) ontwikkeling van een integraal afwegingskader voor inpassing van menselijke ingrepen en activiteiten binnen de grenzen van de draagkracht van het Noordzee ecosysteem,

- $\quad$ stimuleren van natuurontwikkeling bij aanleg offshore installaties;

- $\quad$ pilots rond meervoudig ruimtegebruik; en

- $\quad$ kennisontwikkeling over de technische en ecologische kosten en baten van waterstofopslag. Voor de meeste van deze prioriteiten zijn geen lopende onderzoeksprojecten en zullen nieuwe programma's moeten worden opgezet.

De bovengenoemde thema's zijn verder uitgewerkt in deelprogramma's in de Programmeringsstudie Duurzame Noordzee (Steins et al., 2019).

In het Ontwerp voor het Klimaatakkoord (Klimaatberaad, 2018) is voor de Noordzee een opgave voor het reserveren van $14.000 \mathrm{~km} 2$ voor zeewier en natuurontwikkeling opgenomen. De kennis- en innovatie opgave voor zeewier wordt uitgewerkt binnen de Programmeringsstudie Biogrondstoffen (Elbersen et al., 2019). Dit geldt ook voor het thema 'Beheer ecologische systemen in schelpdierproductie in Waddenzee en Zeeuwse wateren met winning biomassa'.

\subsection{Financiering kennis- en innovatieopgaven}

Voor ieder van de kennisvragen is in de onderliggende spreadsheet in kaart gebracht of het een kennis- of innovatieopgave of beide is, of er lopende monitoring of basisgegevens beschikbaar zijn (en binnen welk programma), of er lopende onderzoeksprogramma's zijn en of er (voor zover bekend) onderzoeksvoorstellen zijn ingediend. In de spreadsheet is ook aangegeven of de vraag zich zou lenen voor topsectorfinanciering.

Het lopende onderzoek en bestaande programma's worden in de Programmeringsstudie Duurzame Noordzee (Steins et al., 2019) beschreven.

Van de 116 witte vlekken in de kennis- en innovatievragen voor de Noordzee (exclusief visserij) zijn voor 39 vragen basisgegevens (veelal via lopende monitoringprogramma's) geheel of gedeeltelijk voorhanden. Rond 39 vragen loopt er onderzoek dat de vraag geheel of gedeeltelijk kan beantwoorden, terwijl 51 en 64 vragen niet worden opgepakt binnen lopende onderzoek- en monitoringprogramma's, respectievelijk. Van de witte vlekken lenen 20 zich voor topsectorinitiatief en zijn er 23 misschien geschikt als topsectorinitiatief. Van 3 witte vlekvragen is aangegeven dat deze geschikt zijn voor topsectorfinanciering. Bijlage 9 geeft het overzicht van de vragen die (mogelijk) geschikt) zouden zijn voor topsectorinitiatief/financiering. Het karakter van 3 vragen maakt dat zij onder publieke financiering (ministeries) zouden moeten vallen. Deze zijn weergegeven in Bijlage 10.

\footnotetext{
${ }^{1} \mathrm{Bij}$ een te grote uitbreiding van windparken op zee kan de wind een beperkende factor worden, wat niet alleen economische effecten heeft voor de windenergiebedrijven. Een opschaling van windparken op zee kan ook fysische effecten geven zoals het verminderen van enerzijds de gemiddelde windsnelheden en daarmee ook golfhoogtes. Anderzijds veroorzaakt de aanwezigheid van de palen van turbines veel menging van de waterkolom. Beide processen hebben invloed op opwerveling van slib en dus op doorzicht en dit soort fysische effecten kunnen in theorie grote gevolgen hebben voor de stratificatie van de waterkolom en uiteindelijk de ecologie van de Noordzee.
} 
Voor de overige 40 vragen zijn meerdere vormen van financiering (privaat (inclusief charitatief), publiek-privaat, publiek) denkbaar.

Voor alle witte vlekken is in de overzichtsspreadsheet opgenomen of de vraag een meer fundamenteel, toegepast, praktijkgericht onderzoekskarakter heeft of een consultancyvraag betreft.

Waar bekend zijn voor 73 van de 116 witte vlekvragen onderzoeksvoorstellen ingediend, bijvoorbeeld bij de topsector call Agri \& Food 2019 of bij NWA. Van deze witte vlekken vragen waren er 69 opgenomen in het afgewezen NWA-NSiT voorstel.

De centrale kennis- en innovatiethema's uit Hoofdstuk 4.3 zijn uitgewerkt in deelprogramma's in het hoofdrapport, de Programmeringsstudie Duurzame Noordzee (Steins et al., 2019). Voor ieder van de deelprogramma's en onderliggende kennis- en innovatieopgaves is hierbij aangegeven of er de opgave zich leent voor publieke of private financiering of combinaties daarvan.

Ook mogelijke consortia en financiering staan beschreven in dit hoofdrapport (Steins et al., 2019). In dit achtergrondrapport is daarover geen extra informatie verzameld. 


\section{$5 \quad$ Uitgebreide resultaten Programmeringsstudie Visserij}

\subsection{Inleiding}

Dit hoofdstuk bevat de uitgebreide resultaten voor de Programmeringsstudie Visserij. Na een korte samenvatting van de maatschappelijke opgave en de missie, wordt een kort overzicht gegeven van lopend onderzoek. Daarna worden de resultaten van de witte vlekken analyse beschreven en wordt aangeven welke mogelijke consortia en financieringsmogelijkheden er zijn. Tenslotte wordt een programmeringsadvies gegeven.

De Programmeringsstudie Visserij richt zich op de maatschappelijke opgave van een duurzame kusten zeevisserij. Duurzame viskweek is geen onderdeel van deze programmeringsstudie. De andere gebruiksfunctie rond voedsel uit zee, maricultures (bijv. zeewier- en schelpdierkweek), is onderdeel van de Programmeringsstudie Biogrondstoffen en is in het betreffende aparte rapport opgenomen (Elbersen et al., 2019). Daar waar het gaat om meervoudig ruimtegebruik van bijvoorbeeld windenergie en visserij en/of maricultures is dit opgenomen in de Programmeringsstudie Duurzame Noordzee (Hoofdstuk 4 van dit rapport). De drie Programmeringsstudies Duurzame Noordzee (Hoofdstuk 4), Visserij (dit hoofdstuk) en Biogrondstoffen (aparte rapportage, (Elbersen et al., 2019)) kunnen los van elkaar gelezen worden, maar zullen in de beleidsmatige uitwerking van het programmeringsadvies één geheel moeten vormen. Vanuit de TKI Blue Growth is na overleg over overlap tussen studies het thema 'circulaire visserij' aan de programmeringsstudie Visserij toegevoegd. In deze achtergrondstudie wordt aan het thema 'circulaire visserij' verder geen tekst gewijd, omdat dit buiten de programmeringsstudie Visserij om uitgewerkt is.

\subsection{Maatschappelijke opgave}

De maatschappelijke opgave staat uitgebreid beschreven in de Programmeringsstudie Visserij (Smith et al., 2019). Tegen de achtergrond van de maatschappelijke opgave heeft het Ministerie van LNV ambities en innovatie- en kennisvragen omschreven voor Duurzame visserij (Tabel 1), die ook omschreven staat in de Programmeringsstudie, maar hier herhaald wordt omwille van de duidelijkheid:

Tabel 13. Ambities en innovatieopgaven voor een Duurzame Visserij. Bron: LNV (2019). De kennis- en innovatievragen rondom viskweek maken geen deel uit van de programmeringsstudie Visserij, wel van het MMIP Blue Growth.

\begin{tabular}{|c|c|}
\hline Ambities 2030 & Innovatie- en kennisvragen \\
\hline $\begin{array}{l}\text { De visserij heeft verdiencapaciteit zonder negatieve } \\
\text { effecten op het ecosysteem en opvarenden, en maakt } \\
\text { optimaal gebruik van diversificatie in te vangen soorten } \\
\text { en voorkomt daarmee verspilling. }\end{array}$ & $\begin{array}{l}\text { - Hoe te komen tot visserij met minder emissie, } \\
\text { betere arbeidsomstandigheden, } \\
\text { diervriendelijker, met minder bodemberoering } \\
\text { en selectiever, terwijl toch een goede } \\
\text { boterham verdiend wordt? } \\
\text { Ontwikkelen betere en nieuwe methoden voor } \\
\text { viskweek. }\end{array}$ \\
\hline
\end{tabular}




\subsection{Lopend onderzoek}

Het lopende onderzoek staat beschreven in de programmeringsstudie Visserij (Smith et al., 2019).

\subsection{Witte vlekken}

De belangrijkste witte vlekken staan beschreven in het hoofdrapport (Smith et al., 2019). Hieronder wordt in meer detail ingegaan op hoe witte vlekken geïdentificeerd zijn. In Bijlage 11 staat een uitgebreide lijst met bijbehorende kennis- en innovatievragen.

\subsubsection{Mind-map kennis- en innovatievragen}

Op basis van de interviews, de enquête en de Noordzee Kennisagenda zijn in totaal meer dan 130 visserij-gerelateerde kennis- en innovatievragen geïdentificeerd (Bijlage 11). Deze kennisvragen zijn tot stand gekomen door het combineren van op elkaar lijkende vragen (clusteren) uit de verschillende bronnen. Het absolute aantal is daarom niet relevant, het gaat om de orde van grootte. De vragen zijn gecategoriseerd rondom de zes subthema's Minder emissies, Betere arbeidsomstandigheden, Dierenwelzijn, Minder bodemberoering, Selectiever vissen en Overig. Figuur 3 geeft de 'mind-map' voor Visserij weer.

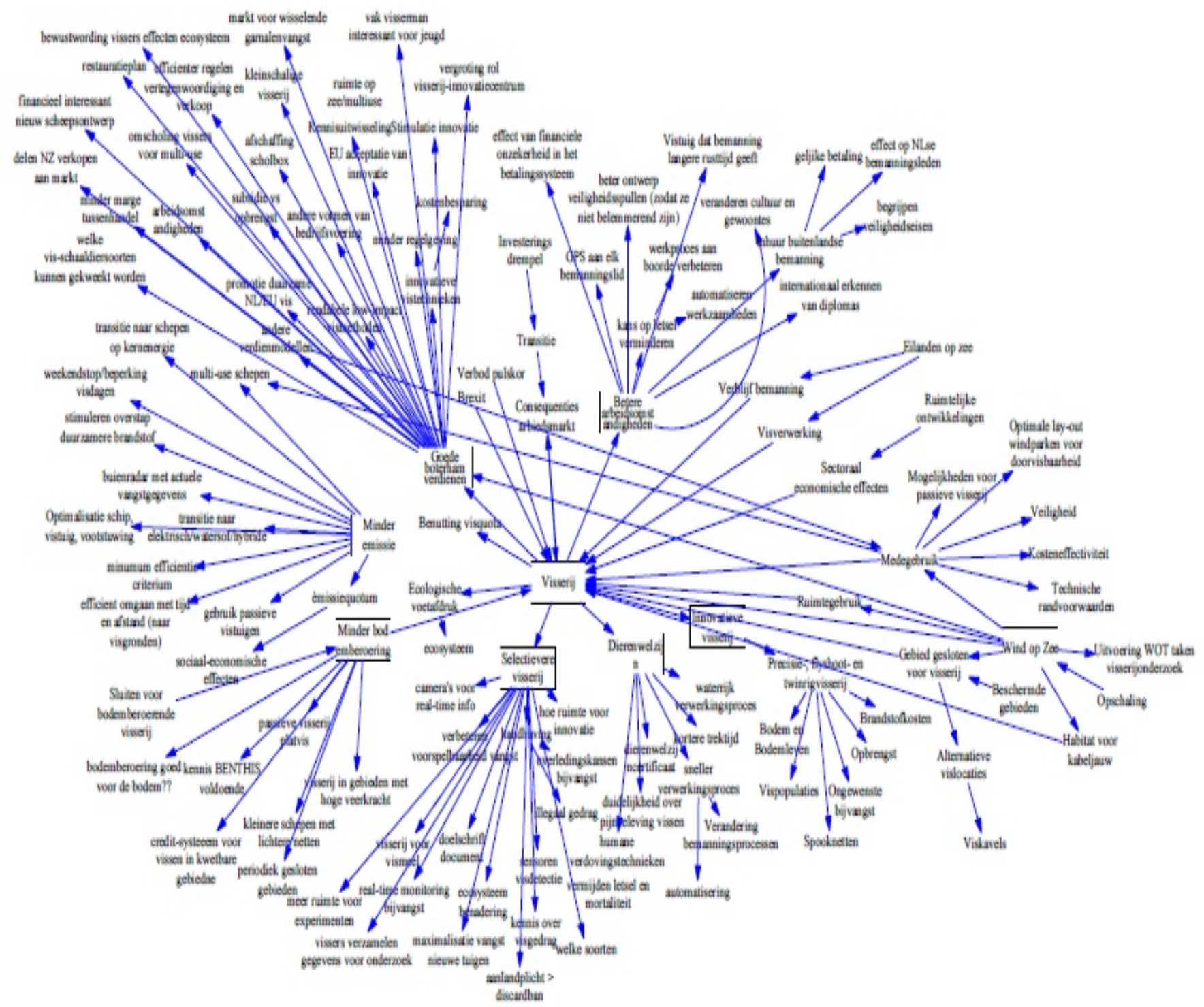

Figuur 3. 'Mind-map' Visserij. 


\subsubsection{Witte vlekken analyse kennis - en innovatievragen}

Van de 132 Visserij-gerelateerde vragen zijn 128 gecategoriseerd als 'witte vlek' (via expertoordeel), ofwel vragen waaraan nog niet wordt gewerkt. Dit betekent dat de andere 4 kennis- en innovatievragen blinde vlekken betreft. Deze vragen zijn al wel onderzocht echter de uitkomsten van het onderzoek zijn niet terecht gekomen bij de betreffende stakeholder. De als witte vlekken geïdentificeerde vragen zijn op te delen in 91 volledige witte vlekken en 37 gedeeltelijk witte vlekken (Tabel 14).

Tabel 14. Totaal aantal kennis- en innovatievragen en of ze een volledige, gedeeltelijke of geen witte vlek zijn.

\begin{tabular}{ll} 
Witte vlek? & Aantal kennisvragen \\
Gedeeltelijk & 37 \\
\hline Ja & 91 \\
\hline Nee & 4 \\
\hline Totaal & 132 \\
\hline
\end{tabular}

De witte vlekken zijn opgesplitst per subthema; minder emissies (ME), betere arbeidsomstandigheden (BA), dierenwelzijn (DW), minder bodemberoering (MB), selectiever vissen (SV) en het verdienen van een goede boterham (GB). Waar een vraag niet specifiek van toepassing was op één van deze subthema's is de vraag opgenomen onder Overig (O). Voor de subthema's zijn respectievelijk 11, 8, 8, 12, 19 en 47 vragen geïdentificeerd. Daarnaast vielen 23 vragen onder het subthema Overig (Tabel 5). Het overgrote deel van de witte vlekken betreft een Kennisopgave (105), 18 vragen betreffen primair een Innovatieopgave, terwijl 5 kennisvragen zowel een Kennis- als een Innovatieopgave betreffen (Tabel 16).

Tabel 15. Aantal kennis- en innovatievragen per subthema. ME - minder emissies, BA - Betere arbeidsomstandigheden, DW - Dierenwelzijn, MB - Minder bodemberoering, SV - Selectiever vissen en $\mathrm{O}$ - Overig.

\begin{tabular}{|c|c|c|c|c|c|c|c|c|}
\hline Witte vlek? & ME & BA & DW & MB & SV & GB & 0 & Totaal \\
\hline Gedeeltelijk & 5 & 2 & 5 & 7 & 2 & 10 & 6 & 37 \\
\hline $\mathrm{Ja}$ & 6 & 6 & 3 & 5 & 17 & 37 & 17 & 91 \\
\hline Nee & & 1 & 1 & & & 1 & 1 & 4 \\
\hline Eind totaal & 11 & 9 & 9 & 12 & 19 & 48 & 24 & 132 \\
\hline Witte vlek totaal & 11 & 8 & 8 & 12 & 19 & 47 & 23 & 128 \\
\hline
\end{tabular}

NB. Het aantal vragen per subthema is niet geheel indicatief voor de mate van kennishiaten per subthema. Dit komt doordat vóór de analyse soortgelijke vragen zijn geclusterd.

Tabel 16. Aantal kennisvragen per subthema met een onderverdeling tussen een Kennisopgave, een Innovatie opgave of beiden. ME - minder emissies, BA - Betere arbeidsomstandigheden, DW - Dierenwelzijn, MB - Minder bodemberoering, SV - Selectiever vissen en O - Overig.

\begin{tabular}{lcccccccc} 
Soort vraag? & ME & BA & DW & MB & SV & GB & To \\
Kennisvraag & 6 & 6 & 5 & 11 & 16 & 45 & 16 & 105 \\
\hline Innovatie vraag & 5 & 1 & 2 & 1 & 3 & 0 & 2 \\
\hline Beiden & 0 & 1 & 1 & 0 & 0 & 2 & 5 & 5 \\
\hline Eindtotaal & $\mathbf{1 1}$ & $\mathbf{8}$ & $\mathbf{8}$ & $\mathbf{1 2}$ & $\mathbf{1 9}$ & $\mathbf{4 7}$ & $\mathbf{2 3}$ & $\mathbf{1 2 8}$ \\
\hline
\end{tabular}

Bijlage 11 geeft een overzicht van de verschillende kennis- en innovatievragen per subthema. Een onderverdeling wordt gemaakt tussen gedeeltelijke en volledige witte vlekken. Per kennisvraag wordt aangegeven of het een kennis-, een innovatieopgave of beide is.

\subsubsection{Prioriteiten}

Er liggen nog veel kennis- en innovatievragen omtrent een duurzame kust- en zeevisserij op de Noordzee. Om inzicht te krijgen in welke vraagstukken als eerste opgepakt dienen te worden is tijdens de interviews (vraag 2 en 11) en in de enquête (vragen 14 t/m 19 en 21) aan deelnemers gevraagd aan te geven wat volgens hen prioriteit heeft. Daarnaast is als onderdeel van de workshops op 23 april en 14 mei 2019 aan deelnemers gevraagd een prioritering aan te geven. 
Uit de enquête is gebleken dat minstens $65 \%$ van de respondenten aangeven dat emissies, bodemberoering, selectiviteit en rendabiliteit belangrijk of zeer belangrijk zijn voor een duurzame kust- en zeevisserij op de Noordzee. Bij de interpretatie van deze en de volgende gepresenteerde getallen dient in het achterhoofd te worden gehouden dat de respondenten, zoals beschreven in paragraaf 2.2.1.2, voor ca $50 \%$ uit mensen bestond die met de visserij verbonden zijn, voor ca een kwart uit onderzoekers en voor de rest uit andere stakeholders. Voor betere arbeidsomstandigheden geeft de grootste groep (40\%) aan dat ze niet wist hoe belangrijk de verbetering van de arbeidsomstandigheden voor bemanningsleden is voor een duurzame Noordzeevisserij. Op de vraag welke prioriteit er ligt omtrent een diervriendelijker visserij is een gemengde reactie gegeven (zie Figuur 4 en Figuur 5).
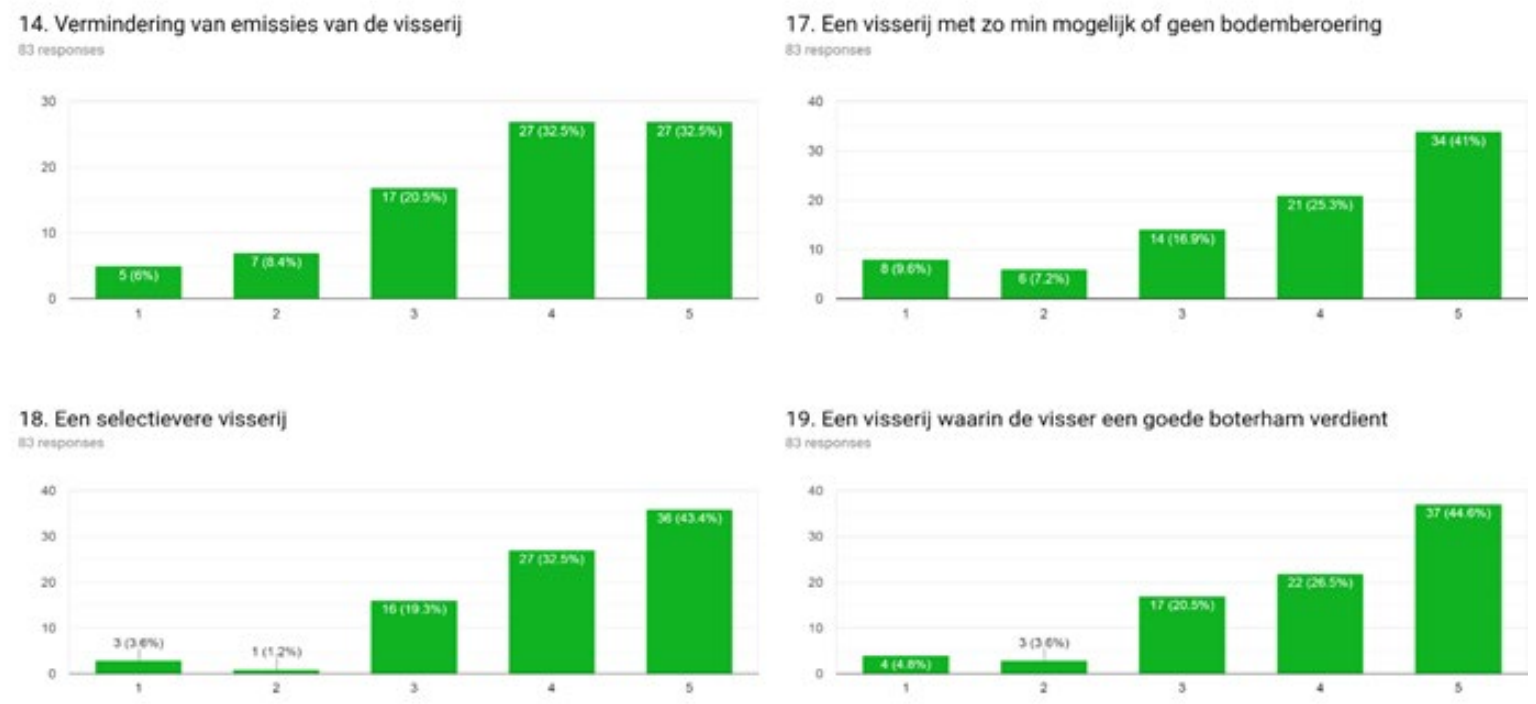

Figuur 4. Prioritering van de subthema's Minder emissies, Minder bodemberoering, Selectievere visserij en Een goede boterham verdienen (1=laag, 5= hoog) door respondenten van de online enquête.

\section{Verbetering van de arbeidsomstandigheden voor bemanningsleden} 83 responses

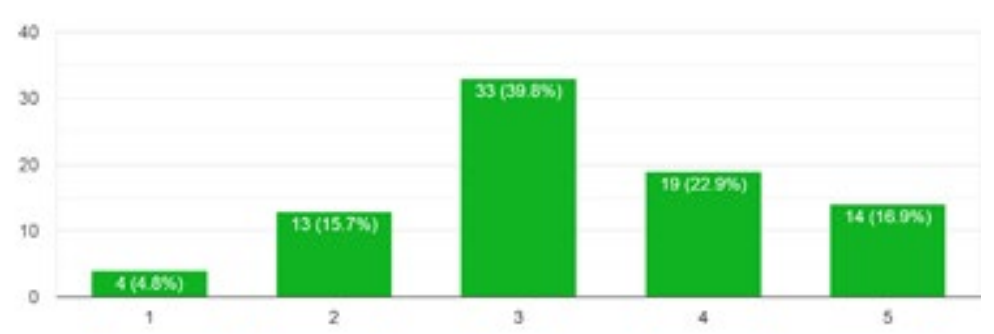

16. Een diervriendelijker visserij 23 responses

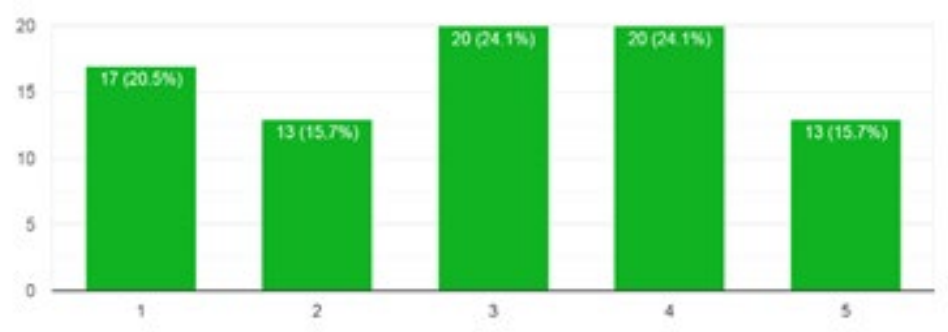

Figuur 5. Prioritering van de subthema's Betere arbeidsomstandigheden en Dierenwelzijn (1=laag, 5= hoog) door respondenten van de online enquête. 
Deze prioritering komt overeen met de antwoorden van de deelnemers op de vraag 'Als $u$ een subsidie van $€ 2$ miljoen euro zou krijgen om aan de slag te gaan voor een duurzame visserij op de Noordzee en kustwateren, welke van de genoemde kennis- en innovatievragen zou u dan als eerste aanpakken?'. De enquête-deelnemers gaven als prioriteit een selectievere visserij (30\%), een rendabel visserijsector (25\%), minder bodemberoering (19\%) en minder emissies (9\%) aan (Figuur 6 ). De respondenten bestonden voor ca $50 \%$ uit mensen verbonden aan de visserij, $25 \%$ onderzoekers en 25 overig (voor details zie 2.2.1.1).

\section{Als u een subsidie van $€ 2$ miljoen euro zou krijgen om aan de slag te gaan voor een duurzame visserij op d...en zou u dan als eerste aanpakken?}
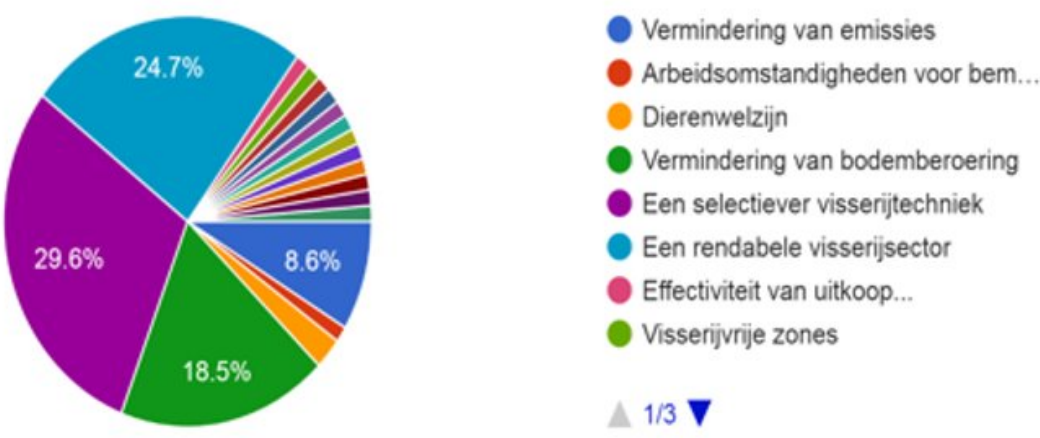

Figuur 6. Uitkomsten op de vraag 21 van de enquête.

De geïnterviewden zijn net als de geënquêteerden ook gevraagd waar volgens hen de prioriteiten liggen in de Visserij-gerelateerde kennis- en innovatievragen. Vaak genoemd als prioriteit waren selectiever en met minder bodemberoering vissen door in te zetten op technische innovaties o.a. ter bescherming van natuurwaarden. Door op deze twee subthema's te focussen zou ook gelijk bijgedragen kunnen worden aan andere subthema's zoals Minder emissies en Dierenwelzijn (via minder bijvangst). Sociale vraagstukken (gedragsverandering, creëren van draagvlak, aantrekkelijkheid van het vissersvak, inpasbaarheid van visserij tussen wind- en natuurparken) en economische vraagstukken (alternatieve verdienmodellen, kostenbesparing) werden tijdens de interviews ook genoemd als belangrijke prioriteiten.

De workshop op 23 april 2019 (zie verslag in Bijlage 3) was bedoeld om te peilen hoe beleidsmakers en wetenschappers zelf over de gepresenteerde witte vlekken dachten, en om de vele kennis- en innovatievragen te bundelen (zie 2.3.1). Gedurende de workshop op 23 april 2019 zijn door de deelnemers binnen de verschillende visserij per subthema's prioriteiten aangegeven aan de vragen die volgens hen belangrijk zijn (17). Deelnemers werden gevraagd om op basis van een set kaarten met kennis- en innovatiehiaten prioritering te geven aan de onderwerpen binnen het subthema. Het verslag van deze workshop is terug te vinden in Bijlage 3. Tabel 17 geeft een overzicht van de prioriteiten zoals ze genoemd zijn tijdens de workshop op 23 april 2019. 
Tabel 17. Prioriteiten per subthema zoals benoemd tijdens de workshop van 23 april 2019.

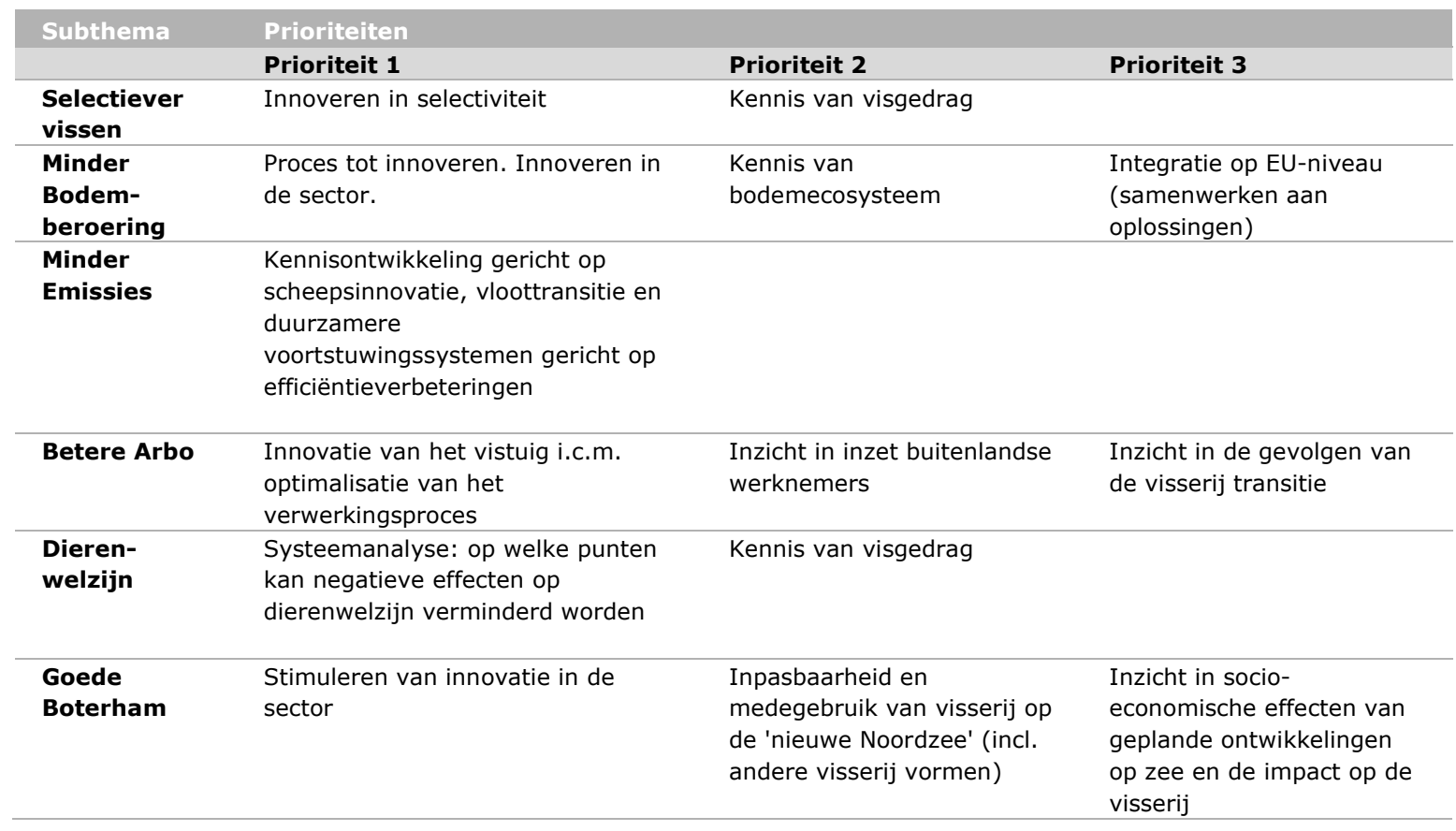

Na de workshop op 23 april 2019 zijn twee subthema's toegevoegd aan de 6 subthema's die door het ministerie van LNV zijn geïdentificeerd. Allereerst is het subthema Versterken van beheer toegevoegd. Gedegen kennis van de visbestanden in de Noordzee is van groot belang om te kunnen bepalen welke vormen van duurzame kust- en zeevisserij plaats kunnen vinden op de Noordzee. Ten twee is het subthema Systeemveranderingen toegevoegd, omdat naast optimalisatie en innovatie op verschillende aspecten van de visserij, ook gekeken moet worden naar het visserij-systeem als geheel. Om te komen tot een toekomstig-bestendig, veerkrachtig en duurzame visserij zou onderzocht moeten worden of de huidige organisatie van de visserij op de Noordzee niet geheel anders opgezet kan worden.

Tijdens de workshop op 14 mei 2019 konden de deelnemers, bestaande uit diverse stakeholders op het gebied van Multi-use (visserij, offshore wind, baggeraars, etc.) door te stickeren, op het concept MMIP Visserij aangeven wat volgens hen prioriteiten waren m.b.t. visserij-gerelateerde kennis- en innovatievragen. In Bijlage 4 is te zien hoe op die dag gestickerd is. Tabel 18 geeft een overzicht van de prioriteiten zoals ze genoemd zijn tijdens de workshop op 14 mei 2019.

Tabel 18. Prioriteiten per subthema zoals benoemd tijdens de workshop op 14 mei 2019.

\begin{tabular}{ll} 
Subthema & Prioriteiten (aantal stickers) \\
Sterker Beheer & $\begin{array}{l}\text { Fundamenteel onderzoek naar de effecten van de aanlandplicht (1); Welke financiering en } \\
\text { aanpalende maatregelen zijn nodig om succesvolle nieuwe visstand-onderzoektechnieken } \\
\text { standaard onderdeel te maken van het visserijonderzoek (1) }\end{array}$ \\
\hline Selectiever vissen & $\begin{array}{l}\text { Hoe kan ruimte (financieel, regelgeving) gegeven worden aan visserijondernemers om te } \\
\text { kunnen innoveren (3); Inzicht in verspreiding van commerciële en niet-commerciële soorten } \\
(1) ; \text { Vaststellen socio-economische effecten van nieuw ontwikkelde vistechnieken (1); } \\
\text { Visserij innovatie Centrum als spil voor innovatie pilots (1). }\end{array}$ \\
\hline Vermindering & $\begin{array}{l}\text { Welke controle \& handhaving maatregelen kunnen toegepast worden (3); Vaststellen van } \\
\text { socio-economische effecten van nieuw ontwikkelde vistechnieken (2); Realiseren van EU } \\
\text { draagvlak bij het toepassen van input-systemen om minder in kwetsbare gebieden te vissen } \\
\text { i.v.m. jurisdictie (2); Hoe kan ruimte (financieel, regelgeving) gegeven worden aan } \\
\text { visserijondernemers om te kunnen innoveren (1). }\end{array}$ \\
\hline Minder emissies & $\begin{array}{l}\text { Fundamenteel en toegepast onderzoek gericht op scheepsinnovatie en duurzamere } \\
\text { voorstuwingssystemen gericht op efficiëntieverbetering (2); Hoe kunnen } \\
\text { visserijondernemers gestimuleerd worden over te stappen naar duurzamere brandstoffen } \\
(1) .\end{array}$ \\
\hline Geen stickers. & $\begin{array}{l}\text { Ontwikkelen van (radicale) innovatieve vistechnieken en netten gericht op het vangen van } \\
\text { doelsoorten alleen (1); Kan een nieuw certificaat ontwikkeld worden met oog op } \\
\text { dierenwelzijn (1). }\end{array}$ \\
\hline Dierenwelzijn &
\end{tabular}


Subthema

Goede Boterham
Hoe kunnen duurzaamheid, ecologie en anticiperen op de ontwikkelingen in de sector goed ingebed worden in het visserijonderwijs (5); Fundamenteel en toegepast onderzoek naar multi-use schepen (2); Toegepast onderzoek naar het inzetten van high tech oplossingen t.b.v. kostenbesparing en opbrengstverhoging in de visserij (2); Fundamenteel en toegepast onderzoek gericht op inpasbaarheid en medegebruik van de visserij op de Noordzee, inzicht in de kansen voor de visserij op de 'nieuwe' Noordzee (1); Versterken inzicht in socio-economische effecten van de ontwikkelingen op de Noordzee (1); Toegepaste kennis m.b.t. alternatieve en nieuwe verdienmodellen visserij (1); Toegepaste kennisontwikkeling in de benodigde toekomstige vaardigheden van vissers om te kunnen blijven vissen in de toekomstige Noordzee (1); Vaststellen van ecologische effecten van nieuw ontwikkelde vistechnieken (1); Uitvoeren van pilots alternatieve vistechnieken in windparken (1); Hoe kunnen visserijondernemers gestimuleerd worden om te innoveren en te anticiperen op de toekomst (1).

Systeem-

veranderingen

\subsection{Kennis- en innovatiethema's en prioritaire onderwerpen}

Het MMIP Visserij bestaat uit het deelprogramma 'Verduurzaming van de zee- en kustvisserij op de Noordzee' opgesplitst in acht deelthema's (zes afkomstig van LNV en twee geïdentificeerd door Wageningen Research). Op basis van de stakeholder workshops liggen voor elk deelthema de prioriteiten bij:

1. Versterken van het beheer van de visbestanden: Kennisontwikkeling van (gegevensarme) visbestanden en hun verspreiding, onderzoek naar de effecten van de aanlandplicht en financiering en aanpalende maatregelen om succesvolle nieuwe visstand-onderzoektechnieken standaard onderdeel te maken van het visserijonderzoek.

2. Verbeteren van selectiviteit: Kennisontwikkeling van visgedrag (in relatie tot vistuig alsook verspreiding) en innoveren in selectiviteit. Gebruik maken van het Visserij Innovatie Centrum als spil voor innovatie pilots en de socio-economische effecten van nieuw ontwikkelde vistechnieken vaststellen.

3. Verminderen van bodemberoering: Kennisontwikkeling van het bodemecosysteem en (ruimte om te) innoveren t.b.v. minder bodemberoering. Integratie op EU-niveau om te komen tot oplossingen. Ruimte voor visserijondernemers om te kunnen innoveren. Inzicht in toe te passen controle $\&$ handhaving maatregelen. Vaststellen van de socio-economische effecten van nieuw ontwikkelde vistechnieken vaststellen.

4. Verminderen van emissies: Onderzoek gericht op scheepsinnovatie, vloottransitie en duurzamere voortstuwingssystemen gericht op efficiëntieverbetering en hoe visserijondernemers gestimuleerd kunnen worden over te stappen naar duurzamere brandstoffen.

5. Verbeteren van arbeidsomstandigheden: Optimaliseren van de vistechniek en het verwerkingsproces aan boord en inzicht in inzet buitenlandse werknemers.

6. Verbeteren van dierenwelzijn: Systeemanalyse van het vis- en verwerkingsproces t.b.v dierenwelzijn en gedragsverandering bij vissers. Het ontwikkelen van (radicale) innovatieve vistechnieken en netten gericht op het vangen van doelsoorten alleen en de mogelijkheden om een nieuw certificaat te ontwikkelen met oog op dierenwelzijn.

7. Verbeteren van economisch perspectief: Visserijondernemers stimuleren om te innoveren, maar ook inzicht krijgen in hoe duurzaamheid, ecologie en anticiperen op de ontwikkelingen in de sector in te bedden in het visserijonderwijs. Inzicht in de inpasbaarheid en medegebruik van de visserij en nieuwe kansen voor visserij op de 'nieuwe' Noordzee. Fundamenteel en toegepast onderzoek naar multi-use schepen en het inzetten van high tech oplossingen. Versterken inzicht in socio-economische effecten van de ontwikkelingen op de Noordzee. Het realiseren van pilots m.b.t. alternatieve vistechnieken in windparken, maar ook inzicht in de ecologische effecten van nieuw ontwikkelde vistechnieken. Toegepaste kennis m.b.t. alternatieve en nieuwe verdienmodellen visserij en kennisontwikkeling in de benodigde toekomstige vaardigheden van vissers.

8. Systeemveranderingen: Kennisontwikkeling naar multi-use schepen en hightech oplossingen. 


\subsection{Financiering kennis- en innovatieopgaven}

Voor ieder van de kennisvragen is in de spreadsheet in kaart gebracht of het een kennis- of innovatieopgave of beide is, of er lopende monitoring of basisgegevens beschikbaar zijn (en binnen welk programma), of er lopende onderzoeksprogramma's zijn en of er (voor zover bekend) onderzoeksvoorstellen zijn ingediend. In de spreadsheet is ook aangegeven of de vraag zich zou lenen voor topsectorfinanciering.

Het lopende onderzoek en bestaande programma's worden in de Programmeringsstudie Visserij (Smith et al., 2019) beschreven.

Van de 128 witte vlekken in de kennis- en innovatievragen voor Visserij zijn voor 30 vragen basisgegevens (veelal via lopende monitoringprogramma's) geheel of gedeeltelijk voorhanden. Rond 32 vragen loopt er onderzoek dat de vraag geheel of gedeeltelijk kan beantwoorden, terwijl 77 vragen niet worden opgepakt binnen lopende programma's. Van de witte vlekken lenen 4 zich voor topsectorinitiatief en zijn er 29 misschien geschikt voor topsectorinitiatief. Bijlage 9 geeft het overzicht van de vragen die (mogelijk) geschikt zouden zijn voor topsectorinitiatief. Het karakter van 5 vragen maakt dat zij onder publieke financiering (ministeries) zouden moeten vallen. Deze zijn weergegeven in Bijlage 10. Voor de overige 28 vragen zijn meerdere vormen van financiering (privaat (inclusief charitatief), publiekprivaat, publiek) denkbaar.

Voor zover bekend zijn voor 24 van de witte vlekken vragen onderzoeksvoorstellen ingediend. Van deze vragen waren er 23 opgenomen in het afgewezen NWA North Sea in Transition voorstel. De ene overgebleven witte vlek is opgenomen binnen VIBEG.

De centrale kennis- en innovatiethema's uit Hoofdstuk 5.3 zijn uitgewerkt in deelprogramma's in het hoofdrapport, de Programmeringsstudie Visserij (Smith et al., 2019). Voor ieder van de deelprogramma's en onderliggende kennis- en innovatieopgaves is hierbij aangegeven of er de opgave zich leent voor publieke of private financiering of combinaties daarvan.

Ook mogelijke consortia en financiering staan beschreven in dit hoofdrapport (Smith et al., 2019). In dit achtergrondrapport is daarover geen extra informatie verzameld. 


\section{Kwaliteitsborging}

Wageningen Marine Research beschikt over een ISO 9001:2015 gecertificeerd kwaliteitsmanagementsysteem. Dit certificaat is geldig tot 15 december 2021. De organisatie is gecertificeerd sinds 27 februari 2001. De certificering is uitgevoerd door DNV GL.

Indien sprake is van onbeheerste kwaliteit worden passende maatregelen genomen. 


\section{Literatuur}

Elbersen, B., Ammerlaan, I., Klein Lankhorst, R., Matser, A., Trindade, L., Lesschen, J.P, Spijker, J., Meer, van der, I., Broese, J., Nabuurs, G.J., Wichers, H., Krimpen, van M., Arets, E., N., Jansen, H., Loo, van R., Veldkamp. T., 2019. Biogrondstoffen. Programmeringsstudie Landbouw, Water en Voedsel.

Klimaatberaad, 2018. Ontwerp van het Klimaatakkoord. Sociaal-Economische Raad, Den Haag (https://www.klimaatakkoord.nl/documenten/publicaties/2018/12/21/ontwerp-klimaatakkoord ).

Matthijsen, J., Dammers, E., Elzenga, H., 2018. De toekomst van de Noordzee. De Noordzee in 2030 en 2050: een scenariostudie, Den Haag: Planbureau voor de Leefomgeving.

Ministerie van LNV, 2019. Nederland als koploper in kringlooplandbouw vraagt om kennis en innovatie met impact: Kennis en innovatieagenda (2019-2030). Ambtelijk werkdocument, Ministerie van Landbouw, Natuur en Voedselkwaliteit, Den Haag.

Ministeries van IenW en van LNV, 2018. Kennisagenda Noordzee 2030. Bijlage van de Strategische Agenda en het Uitvoeringsprogramma Noordzee 2030, Den Haag.

RVO, 2019. Subsidies en financiering. Geraadpleegd op 5 juni 2019 van https://www.rvo.nl/subsidiesregelingen.

Smith S., Bos O.G., van Rijn, J., Schadeberg, A., Tamis J., Steins, N.A., Zaalmink, W., 2019. Programmeringsstudie Landbouw, Water en Voedsel: Visserij. IJmuiden: Wageningen Marine Research No. 1928089.

Steins N.A., Van den Bogaard L., Maarse M., Smith M., Tamis J., Tatman, S., 2019. Duurzame Noordzee. Programmeringsstudies Landbouw, Water en Voedsel. Wageningen Marine Research; Deltares. IJmuiden: Wageningen Marine Research No. 1928089.

Van Duren, L., Poelman, M., Jansen, H., Timmermans, K., 2019. Een realistische kijk op zeewierproductie in de Noordzee. Gezamenlijke notitie van Wageningen Marine Research, NIOZ en Deltares, als onderdeel van Beleidsondersteunend Onderzoek Natuurinclusieve energie (BO-43023.03-005). Yerseke: Wageningen Marine Research No. 1930336-MP-LvdB-Ics.

van Oostenbrugge, J.A.E., Steins, N.A., Mol, A., Smith, S.R., Turenhout, M.N.J., 2018. Mosseltransitie en natuurherstel: sociaaleconomische draagkracht en ontwikkelingen Nederlandse mosselsector, 2008-2017. Den Haag: Wageningen Economic Research No. 2018-040. 


\section{Verantwoording}

Rapport C075.19

Projectnummer: 4316100183

Dit rapport is met grote zorgvuldigheid tot stand gekomen. De wetenschappelijke kwaliteit is intern getoetst door een collega-onderzoeker en het verantwoordelijk lid van het managementteam van Wageningen Marine Research

Akkoord:

ing. M. Poelman

Onderzoeker

Handtekening:

Datum:

01-08-2019

Akkoord:

Drs. J. Asjes

MT lid Integratie

Handtekening

Datum:

01-08-2019 


\section{Bijlage 1 Interviewvragen}

\section{Aanleiding}

Het Ministerie van Landbouw, Natuur en Voedselkwaliteit (LNV) en de Topsector Agri \& Food hebben Wageningen Research (WR) gevraagd een inventarisatie uit te voeren van bestaande kennis- en innovatievragen in relatie tot zeevisserij op de Noordzee. Deze inventarisatie draagt bij aan de gezamenlijke Kennis- \& Innovatie Agenda 2019 - 2030 (Ministerie van LNV, 2019).

\section{Achtergrond}

Vanuit het regeerakkoord en de EU zal ingezet worden op een missie gedreven innovatiebeleid. Het Ministerie van LNV heeft 6 missies geïdentificeerd binnen het thema Landbouw, Water, Voedsel. De missies baseren zich op bestaande beleidsnota's, lopende beleidsprogramma's en topsectoragenda's. Eén van de missies (Missie E.) richt zich op "duurzame en veilige Noordzee, oceanen en binnenwateren", bestaande uit 5 subthema's: Noordzee; Cariben; Rivieren, meren en intergetijdengebieden; Overige oceanen en zeeën; en Visserij.

Voor het subthema Visserij ligt er de volgende ambitie voor 2030:

"De visserij heeft verdiencapaciteit zonder negatieve effecten op het ecosysteem en opvarenden, en maakt optimaal gebruik van diversificatie in te vangen soorten en voorkomt daarmee verspilling."

Focus ligt hierbij om te komen tot:

"Een visserij met minder emissies, betere arbeidsomstandigheden, diervriendelijker, met minder bodemberoering en selectiever, terwijl toch een goede boterham verdiend wordt."

Via onderstaande vragen horen wij graag van de geïnterviewde welke uitdagingen, maar vooral welke kennis- en innovatievragen er liggen met betrekking tot bovenstaande genoemde 5 aspecten (minder emissies, arbeidsomstandigheden, dierwelzijn, minder bodemberoering en selectiviteit en een goede boterham verdienen rekening houdend met voorgaande aspecten) van een toekomstige visserij. Na de inventarisatie van bestaande kennis- en innovatie vragen zal gekeken worden welke van deze vragen al via lopende onderzoeksprojecten en programma's beantwoord (kunnen) worden en worden de witte vlekken geïdentificeerd.

\section{Hoe past de programmeringsstudie Visserij naast andere sporen?}

Strategie Agenda Noordzee $\mathbf{2 0 3 0}$ (betrokken beleidspersonen o.a. Ton IJlstra en Wim van Urk): een strategisch plan om de Klimaatakkoord doelstellingen (NL: 49\% minder uitstoot van broeikasgassen t.o.v. 1990; voor 2030 te behalen). De Strategie Agenda Noordzee 2030 kent 3 strategische opgaven:

- $\quad$ Bereiken van een gezonde zee met een duurzaam en verantwoord gebruik;

- In balans realiseren van de energietransitie, natuurherstel en voedselvoorziening, in samenhang met de ontwikkeling van andere sectoren en kustregio's;

- Bevorderen van een innovatieve en concurrerende Blauwe Economie.

Overlegorgaan Fysieke Leefomgeving (Wallage-traject): 'Verkenning Noordzeestrategie 2030' t.b.v. advisering over hoe een duurzame samenwerking tot stand is te brengen tussen het Rijk en de stakeholders rondom de gezamenlijke strategische keuzes voor het Noordzeebeleid en beheer; i.h.k.v. de totstandkoming van de Strategisch Agenda Noordzee 2030.

Kennisagenda Noordzee 2030: Bij de opstelling van de Strategie Agenda Noordzee 2030 (NZS2030) zijn veel kennisvragen gesteld door overheid, stakeholders en kennisinstellingen. Er is al veel kennis over de Noordzee beschikbaar, maar ook vele onderwerpen vragen om verder onderzoek. Hiertoe is de NZS2030 Kennisagenda opgesteld. De Kennisagenda Noordzee 2030 gaat in op de kennisleemten die gerelateerd zijn aan de tweede en derde opgave van de Strategie Agenda Noordzee 2030. 
De programmeringsstudie Visserij focust zich op het inventariseren van bestaande kennis- en innovatievragen rondom zeevisserij op de Noordzee, een overzicht van in hoeverre deze kennisen innovatievragen al opgepakt worden in bestaande onderzoeksprogramma's en het identificeren van de witte vlekken. Vervolgens wordt gekeken hoe, en met welke partijen en welke financieringsmogelijkheden deze witte vlekken opgepakt kunnen worden.

\section{Aandachtspunt}

- Toestemming vragen aan geïnterviewde of gesprek opgenomen mag worden.

- Aangeven dat antwoorden van geïnterviewde volledig anoniem behandeld worden en niet gedeeld met andere partijen. Als in het onderzoeksrapport over resultaten uit het interview wordt geschreven, is dit niet te herleiden tot individuele personen.

- Indien de geïnterviewde een vraag wil overslaan dan is dat uiteraard toegestaan.

\section{Vragen}

1. Kunt u kort aangeven wie u bent en wat uw achtergrond is?

2. Als we moeten komen tot een duurzame visserij in 2030 , wat zijn volgens u de 3 kernfactoren waar het beleid op moet focussen?

a. Welke kennis-\& innovatievragen liggen hiervoor?

b. Welke belemmeringen ziet u om dat doel te verwezenlijken op dit moment?

Interviewer vertelt kort over de LNV-missies en de ambitie 2030 voor Visserij, waarbij focus ligt op minder emissie, betere arbeidsomstandigheden, dierwelzijn, minder bodemberoering en selectiviteit, goede boterham verdienen rekening houdend met voorgaande aspecten (zie achtergrond).

3. LNV streeft naar een reductie van emissie (brandstof) van de visserij. Wat is daarvoor volgens u nodig?

a. En wat moet volgens u worden onderzocht of ontwikkeld?

b. Welke belemmeringen ziet $u$ om dit doel te bereiken?

4. Een deel van de missie van LNV is om de arbeidsomstandigheden van de bemanning te verbeteren. Wat is daarvoor volgens u nodig?

a. En wat moet volgens u worden onderzocht of ontwikkeld?

b. Welke belemmeringen ziet $u$ om dit doel te bereiken?

5. LNV streeft naar een diervriendelijker visserij. Wat is daarvoor volgens u nodig?

a. En wat moet volgens u worden onderzocht of ontwikkeld?

b. Welke belemmeringen ziet $\mathrm{u}$ om dit doel te bereiken?

6. Uiteindelijk streeft LNV naar een visserij met zo min mogelijk bodemberoering. Hoe zou dit kunnen worden gedaan volgens $u$ ?

a. En wat moet daarvoor worden ontwikkeld of onderzocht?

b. Welke belemmeringen ziet u om dit doel te bereiken?

7. In 2030 ligt de ambitie om een selectievere visserij te hebben. Wat is volgens u een oplossing?

a. Wat moet daarvoor worden ontwikkeld of onderzocht?

b. Welke belemmeringen ziet $\mathrm{u}$ om dit doel te bereiken?

8. Rekening houdend met bovengenoemde ambities wat moet er volgens u gebeuren binnen de visserij om een goede boterham te verdienen?

a. Wat moet daarvoor worden ontwikkeld of onderzocht?

b. Welke belemmeringen ziet u om dit doel te bereiken?

9. Welke rol kan uw organisatie (of achtergrond) spelen in het realiseren van antwoorden op de vragen? 
a. Welke andere instanties zouden volgens u hierbij kunnen helpen?

10. Kunt $\mathrm{u}$ bestaande financieringsmogelijkheden/subsidieregelingen noemen die inzet kunnen worden om de ambitie van LNV te realiseren?

11. Als u 2 miljoen euro zou krijgen welk van de genoemde kennis- en innovatievragen zou u dan als eerste tackelen?

12. Stel u bent een visser, het is 2030 , uw bedrijf is rendabel én duurzaam - wat heeft u gedaan om het zo te krijgen?

13. Terugkoppeling - in het begin van ons gesprek gaf u 3 kernfactoren aan waarop het beleid haar aandacht zou moeten vestigen als het gaat om een duurzame visserij in 2030 . $\mathrm{Nu} u$ de prioriteiten van LNV kent, wat is hierop uw reactie?

Dank u wel voor uw tijd! 


\section{Bijlage 2 Enquêtevragen}

Kennis- en Innovatievragen voor een Duurzame Visserij op de Noordzee en Kustwateren Het Ministerie van Landbouw, Natuur en Voedselkwaliteit (LNV) en de Topsectoren Agri \& Food en Tuinbouw \& Uitgangsmaterialen hebben Wageningen Research (WR) gevraagd een inventarisatie uit te voeren van kennis- en innovatievragen in relatie tot zeevisserij op de Noordzee. Deze inventarisatie draagt bij aan de gezamenlijke Kennis \& Innovatie Agenda van het ministerie en de topsectoren. Via deze enquête hopen we kennis- en innovatievragen op te halen die in de huidige onderzoeksprogrammering nog niet worden gedekt ('blinde vlekken'), maar die wel belangrijk zijn voor het verder realiseren van een duurzame visserij.

Wij vragen u om deze enquête zo volledig mogelijk en vanuit uw eigen perspectief in te vullen. Een deel van de enquête bestaat uit open vragen en een deel uit gesloten vragen, waar gevraagd wordt een keuze(s) te maken. Uw ingevulde formulier wordt volledig anoniem behandeld en wordt niet gedeeld met andere partijen. Als in het onderzoeksrapport over resultaten uit de enquête wordt geschreven, is dit niet te herleiden tot individuele personen. Het invullen van de enquête kost ongeveer 15 minuten. Wij vragen u om deze enquête zo volledig mogelijk en vanuit uw eigen perspectief in te vullen. Een deel van de enquête bestaat uit open vragen en een deel uit gesloten vragen, waar gevraagd wordt een keuze(s) te maken. Uw ingevulde formulier wordt volledig anoniem behandeld en wordt niet gedeeld met andere partijen. Als in het onderzoeksrapport over resultaten uit de enquête wordt geschreven, is dit niet te herleiden tot individuele personen.

Mocht u vragen hebben, dan kunt u contact opnemen met Sarah Smith, tel. 0317-487218, of Oscar Bos, tel. 0317-487071.

Hartelijk dank voor uw medewerking!

$*$ Required

\section{Wie bent $u$ ? (U kunt meer dan 1 optie kiezen) *}

Tick all that apply.

- Visser - bemanningslid

- Visser - schipper

- Visser - scheepseigenaar

- Ex-visser

- Werkzaam bij een NGO

- Werkzaam bij de overheid

- Onderzoeker (Wageningen)

- Onderzoeker (ander instituut)

- Consultant/adviseur

- Duiker (scuba)

- Student

- Natuurbetrokken vrijwilliger

- Burger kustgemeente

- Andere burger

o Other:

\section{De visie van LNV voor een duurzame Noordzee}

Vanuit het regeerakkoord en de EU wordt ingezet op een missie-gedreven innovatiebeleid. Het Ministerie van LNV heeft zes missies geïdentificeerd binnen het thema Landbouw, Water, en Voedsel. De missies baseren zich op bestaande beleidsnota's, lopende beleidsprogramma's en topsectoragenda's. Eén van de missies richt zich op "Duurzame en veilige Noordzee, oceanen en binnenwateren".

Voor het subthema Visserij ligt er de volgende ambitie voor 2030:

"De visserij heeft verdiencapaciteit zonder negatieve effecten op het ecosysteem en opvarenden, en maakt optimaal gebruik van diversificatie in te vangen soorten en voorkomt daarmee verspilling." De focus ligt hierbij op de vraag: 
"Hoe te komen tot een visserij met minder emissie, betere arbeidsomstandigheden, diervriendelijker, met minder bodemberoering en selectiever, terwijl toch een goede boterham verdiend wordt?"

Via het beantwoorden van de volgende vragen horen wij graag welke uitdagingen, maar vooral ook welke kennis- en innovatievragen er volgens $u$ liggen met betrekking tot bovenstaande vraag.

2. De emissie (brandstof) van de visserij moet verder worden verminderd. Wat is daarvoor volgens u nodig? U kunt meer dan 1 optie kiezen. Gebruik vooral "anders/other" om toe te voegen wat volgens u ontbreekt. *

Tick all that apply.

- Technologie - elektrische schepen

Technologie - LPG schepen

Technologie - LNG schepen

Technologie - waterstof schepen

Technologie - hybride schepen

Technologie - aanpassingen in de voortstuwing t.b.v. minder gasolieverbruik

Technologie - passend infrastructuur aan wal (elektrisch, LNG, LPG, etc.)

Beheer - geen gebruik van slepende/zware vistuigen (b.v. boomkor)

Beheer - geen gebruik van verafgelegen visgronden

Beheer - meer kleinschalig vissen

Beheer - minder visdagen

Other:

3. Wat moet volgens u worden onderzocht of ontwikkeld om een vermindering van emissies te realiseren? $*$

4. Een deel van de missie is om de arbeidsomstandigheden van de bemanning te verbeteren.

Wat is volgens u daarvoor nodig? $U$ kunt meer dan 1 optie kiezen. Gebruik vooral "anders/other" om toe te voegen wat volgens u ontbreekt. *

Tick all that apply.

- Gezondheid - beter slaapritme en meer rusttijd

Gezondheid - betere voeding aan boord

Gezondheid - minder blootstelling aan schadelijke dampen

Gezondheid - gehoorbescherming

Veiligheid - strengere regels voor gebruik van reddingsvesten

Veiligheid - verplichting helm dragen

Veiligheid - verplichting PLB (personal life beacons)

Veiligheid - betere opleiding met betrekking tot zwaar tillen

Veiligheid - betere naleving bestaande regels

Financiële zekerheid - gegarandeerd minimumloon

Financiële zekerheid - betere arbeidsovereenkomsten

Financiële zekerheid - voorrang voor Nederlandse bemanningsleden

Opleiding - trainingen voor buitenlandse bemanningsleden (Nederlandse taal, arbo en veiligheid)

○ Opleiding - meer Safety at Sea trainingen

o Other:

5. Wat moet er volgens u worden onderzocht of ontwikkeld om tot betere arbeidsomstandigheden te komen? *

6. Dierenwelzijn is een van de ambities voor 2030. Hoe kan de visserij diervriendelijker worden en wat is daarvoor volgens u nodig? $U$ kunt meer dan 1 optie kiezen. Gebruik vooral "anders/other" om toe te voegen wat volgens u ontbreekt. *

- Tick all that apply.

- Verwerking aan boord - snellere verwerking (minder stress voor de vis van het water tot het koelruim)

- Verwerking aan boord - handmatig verdoven en doden van de vis (voor het strippen)

- Verwerking aan boord - automatisch verdoven en doden met mes of spijker (voor het strippen) 


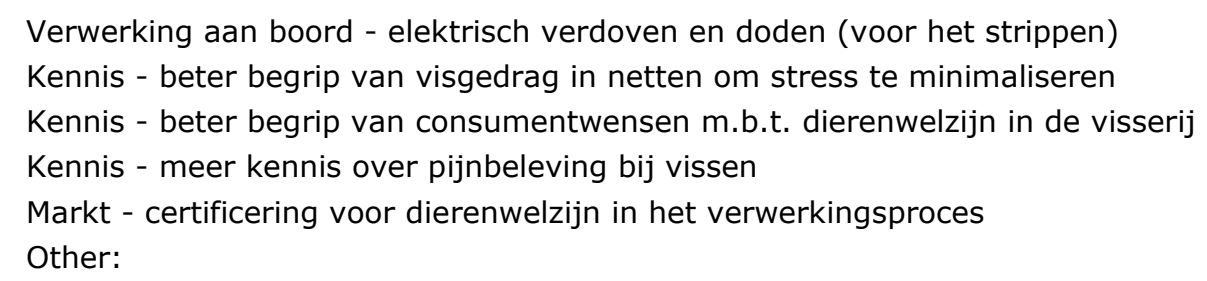

7. Welke kennis moet volgens u worden ontwikkeld, of wat zou moeten worden onderzocht om dierenwelzijn in de visserij te bevorderen? *

8. De overheid streeft naar een visserij met zo min mogelijk of geen bodemberoering. Hoe zou dit volgens u gerealiseerd kunnen worden? $U$ kunt meer dan 1 optie kiezen. Gebruik vooral "anders/other" om toe te voegen wat volgens u ontbreekt. *

Tick all that apply.

- Vangstmethode - overstappen van actieve (sleepnetten) naar passieve vistuigen

- (staandwantnetten, fuiken, handlijnen, etc.)

- Vangstmethode - innovatie van een actief vistuig zonder bodemberoering

- Vangstmethode - gebruik van waterstralen om vissen in het net te leiden

- Vangstmethode - gebruik van luchtdruk om vissen in het net te leiden

- Beheer - stimuleren van het vissen in minder kwetsbare gebieden

- Beheer - beperking instellen voor het vissen in kwetsbare gebieden

- Beheer - meer gesloten gebieden

- Beheer - meer controle en handhaving van visbeperkingen

- Gebiedskennis - meer kennis ontwikkelen over kwetsbare habitats

- Other:

9. Wat moet volgens u ontwikkeld of onderzocht worden om een visserij met zo min mogelijk bodemberoering te realiseren? *

10. Volgens de ambitie van het ministerie zou in $\mathbf{2 0 3 0}$ de visserij selectiever moeten zijn. Wat zijn volgens u mogelijkheden om dit te bereiken? $U$ kunt meer dan 1 optie kiezen. Gebruik vooral "anders/other" om toe te voegen wat volgens u ontbreekt. *

Tick all that apply.

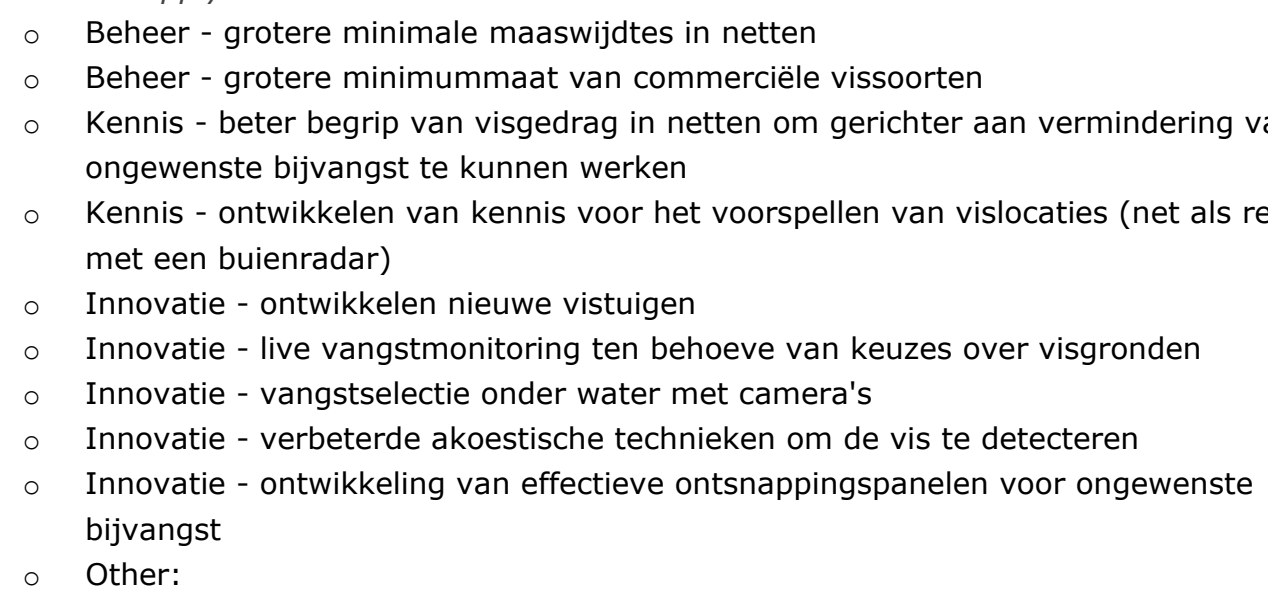

11. Wat moet volgens u ontwikkeld of onderzocht worden om een selectievere visserij te realiseren? *

12. Wat moet er gebeuren binnen de visserij om een goede boterham te verdienen, rekening houdend met bovengenoemde ambities (verbetering in emissies, arbeidsomstandigheden, dierenwelzijn, bodemberoering en selectiviteit)? U kunt meer dan 1 optie kiezen. Gebruik vooral "anders/other" om toe te voegen wat volgens u ontbreekt. *

Tick all that apply.

- Beheer - alternatieve werkzaamheden (bv. monitoring, windparkonderhoud, aquacultuur)

- Beheer - minder regels en beperkingen zodat vissers makkelijker aan innovaties kunnen werken 
- Beheer - meer regels en beperkingen om duurzaamheid aan te moedigen

- Beheer - garantstelling voor risicovolle investeringen

- Subsidie - subsidies om duurzaamheid in de visserij te ondersteunen

- Subsidie - subsidies voor omschakeling naar andere vormen van voedselproductie op zee

- Subsidie - nationale investeringen in medegebruik-mogelijkheden voor de visserij (bv. Andere voedselproductie op zee, offshore-diensten)

- Subsidie - meer ondersteuning voor een visserij-innovatiecentrum (via samenwerking visserij en onderzoek)

- Opleiding - meer aandacht voor hedendaagse maatschappelijke eisen in het visserijonderwijs

- Samenwerking - verbeteren samenwerking tussen de sector, wetenschap en maatschappij

- Other:

13. Wat moet volgens u worden ontwikkeld of onderzocht om de visser een goede boterham te laten blijven verdienen? $*$

\section{Prioriteiten}

Hoe belangrijk vindt u elk van de eerdergenoemde thema's?

( 1 = niet belangrijk tot $5=$ heel belangrijk)

\section{Vermindering van emissies van de visserij *}

Mark only one oval.

12345

$1=$ Niet belangrijk, $5=$ Heel belangrijk

15. Verbetering van de arbeidsomstandigheden voor bemanningsleden *

Mark only one oval.

12345

$1=$ Niet belangrijk, $5=$ Heel belangrijk

\section{Een diervriendelijker visserij *}

Mark only one oval.

12345

$1=$ Niet belangrijk, $5=$ Heel belangrijk

\section{Een visserij met zo min mogelijk of geen bodemberoering *}

Mark only one oval.

12345

$1=$ Niet belangrijk, $5=$ Heel belangrijk

\section{Een selectievere visserij *}

Mark only one oval.

12345

$1=$ Niet belangrijk, $5=$ Heel belangrijk

19. Een visserij waarin de visser een goede boterham verdient $*$

Mark only one oval.

12345

$1=$ Niet belangrijk, $5=$ Heel belangrijk

20. Als u een of meer thema's als heel belangrijk heeft benoemd, kunt u toelichten waarom? *

21. Als u een subsidie van $\mathbf{C 2}$ miljoen euro zou krijgen om aan de slag te gaan voor een duurzame visserij op de Noordzee en kustwateren, welke van de genoemde kennis- en innovatievragen zou u dan als eerste aanpakken? $*$ 


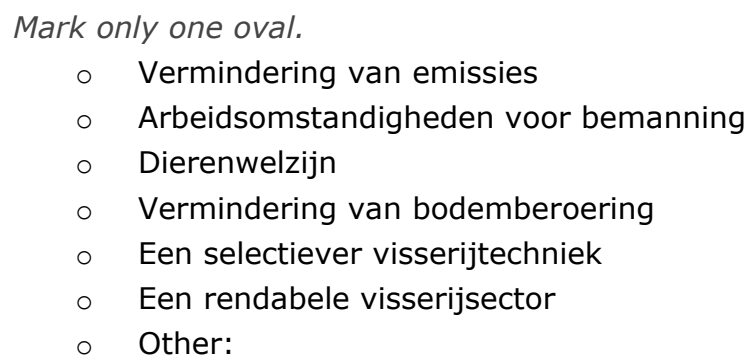

Uw bijdrage aan een duurzamere visserij op de Noordzee en kustwateren

22. Welke rol kunt u of uw organisatie spelen in het helpen beantwoorden van deze kennisen innovatievragen? *

23. Welke andere instanties zouden volgens u hierbij kunnen helpen? *

24. Zou u geïnteresseerd zijn om in contact te blijven over deze bijdrage? Zo ja, laat dan uw emailadres achter en we kunnen contact opnemen over kennis- en innovatiemogelijkheden (niet verplicht).

25. Kunt u bestaande financieringsmogelijkheden of subsidieregelingen noemen waarmee de kennis- en innovatievragen rondom een duurzamere zeevisserij op de Noordzee en kustwateren aangepakt kunnen worden? *

26. Heeft u nog opmerkingen, of ontbreken er volgens u nog zaken in de missie van LNV, als het gaat om een duurzamere visserij op de Noordzee en kustwateren?

\section{Windenergie op de Noordzee}

In een parallel project worden kennis- en innovatievragen geïnventariseerd voor de Noordzee en de grootschalige uitbreiding van windenergie op zee. Wij willen u hierover nog enkele vragen stellen. Het doel van het Noordzee 2030 project is om deze uitbreiding van windenergie zoveel mogelijk in balans te houden met de doelstellingen voor natuur en voedselproductie.

\section{Bent u bekend met de kennisagenda Noordzee 2030 die afgelopen jaar uit de} stakeholderbijeenkomsten naar voren is gekomen? $*$

Mark only one oval.

- Ja (beantwoord a.u.b. de volgende 2 vragen)

- Ik heb er iets van gehoord maar ik weet niet zeker wat het is (sla de volgende 2 vragen over)

- Nee (u bent klaar met deze enquête. Scroll naar beneden en klik Verzenden/Submit)

28. Van de hieronder genoemde kennis- en innovatievragen, welke 2 zijn volgens $u$ het BELANGRIJKSTE voor de komende 10 jaar?

Tick all that apply.

- Hoe de ruimte binnen windparken te kunnen benutten voor andere functies?

- Wat zijn de systeemeffecten van grootschalige productie (windenergie en voedsel) op zee?

- Hoe kan de techniek rond Wind op Zee natuurvriendelijker gemaakt worden, inclusief

- Kustscheepvaart emissieloos, veilig en duurzaam maken?

- Hoe kan geluid op zee door menselijke activiteiten substantieel worden gereduceerd?

- Wat is nodig om de hoeveelheid zwerfafval substantieel te verminderen?

- Hoe kan een volwaardige zeewierketen tot stand worden gebracht die zichzelf economisch in stand houdt?

- Het ontwikkelen van slimme systemen voor monitoring van de ecologische toestand en het waterbeheer

- Welke alternatieve vormen van energie zijn mogelijk op zee mocht het wind op zee project vastlopen door een cumulatie van effecten op de ecologie of ruimtegebrek? 
29. Van de hieronder kennis- en innovatievragen, welke 2 zijn volgens u het MINST BELANGRIJKSTE voor de komende 10 jaar?

Tick all that apply.

- Hoe de ruimte binnen windparken te kunnen benutten voor andere functies?

- Wat zijn de systeemeffecten van grootschalige productie (windenergie en voedsel) op zee?

- Hoe kan de techniek rond Wind op Zee natuurvriendelijker gemaakt worden, inclusief kustscheepvaart emissieloos, veilig en duurzaam maken?

- Hoe kan geluid op zee door menselijke activiteiten substantieel worden gereduceerd?

- Wat is nodig om de hoeveelheid zwerfafval substantieel te verminderen?

- Hoe kan een volwaardige zeewierketen tot stand worden gebracht die zichzelf economisch in stand houdt?

- Het ontwikkelen van slimme systemen voor monitoring van de ecologische toestand en het waterbeheer

- Welke alternatieve vormen van energie zijn mogelijk op zee mocht wind op zee project vastlopen door een cumulatie van effecten op de ecologie of ruimtegebrek?

Dat was de laatste vraag - nogmaals dank! Uw bijdrage helpt ons de huidige onderzoeksprogrammering te verbeteren voor het verder realiseren van een duurzame visserij. 


\title{
Bijlage 3 Verslag workshop beleid en onderzoek 23 april 2019
}

\begin{abstract}
Aanleiding
Nederland staat voor een aantal grote maatschappelijke uitdagingen op het terrein van voedselproductie, gebruik van grondstoffen, klimaatverandering, waterkwaliteit en duurzaam gebruik en beheer van grote wateren. Binnen het thema Landbouw, Water, Voedsel heeft het Ministerie van Landbouw, Natuur en Voedselkwaliteit (LNV) zes missies gedefinieerd om deze maatschappelijke opgaven aan te pakken en ook kansen kunnen bieden voor het versterken van de concurrentiekracht van het Nederlandse bedrijfsleven. De missies vormen ambities voor kennis en innovatie; zij moeten prikkelen tot ambitieus onderzoek en de toepassing ervan in de praktijk. De missies voor Landbouw, Water, Voedsel zijn opgesteld in het kader van het missiegedreven topsectorenbeleid en uitgangspunt voor de topsectoren Agri \& Food, Tuinbouw \& Uitgangsmaterialen, en Water.
\end{abstract}

Het ministerie van LNV en de topsectoren Agri \& Food, Tuinbouw \& Uitgangsmaterialen en Water werken op dit moment aan een gezamenlijke Kennis \& Innovatie Agenda (2020-2024) om te komen tot een samenhangende integrale aanpak die zowel bijdraagt aan het oplossen van maatschappelijke uitdagingen als ook aan het verdienvermogen. Vooruitlopend op de uitwerking van de nieuwe Kennisen Innovatie Agenda loopt er nu al de call van 2019 van de topsectoren Agri \& Food en Tuinbouw \& Uitgangsmaterialen.

De complexiteit van de opgaven vraagt om een gezamenlijke aanpak. Het uitgangspunt voor de gezamenlijke aanpak vormt publiek-private samenwerking bij het vinden en implementeren van oplossingen. Daar waar publiek-private samenwerking alleen niet de oplossing kan vormen om de missiedoelen te bereiken, kan een puur publieke inzet helpen.

Het ministerie van LNV en de topsectoren Agri \& Food en Tuinbouw \& Uitgangsmaterialen hebben Wageningen Research gevraagd om zogenaamde programmeringsstudies uit te voeren en, daaraan gekoppeld, input te leveren voor de Meerjarige Maatschappelijke Innovatie Programma's. Doel van de programmeringsstudies is om een goed beeld te krijgen van de kennis- en innovatievragen voor de verschillende missies, te inventariseren welk onderzoek er al loopt, waar nog lacunes (witte vlekken) zitten, en hoe deze witte vlekken via PPS (topsectoren) of andere programma's kunnen worden opgepakt. Ook de blauwe ruimte is onderdeel van deze programmeringsstudies. Wageningen Research werkt binnen dit thema aan drie aan elkaar gerelateerde programmeringsstudies: (1) Noordzee (i.s.m. Deltares), (2) Visserij en (3) Biogrondstoffen (waaronder biogrondstoffen uit de blauwe ruimte, bijv. via maricultuur).

\section{Aanpak en tussentijdse resultaten}

Deze eerste werksessie was op verzoek van de opdrachtgever gericht op deelnemers uit het beleid (betrokken ministeries bij Noordzee 2030) en onderzoek. Op 14 mei volgt een stakeholder workshop.

Voor de aanpak en tussentijdse resultaten van de programmeringsstudies Noordzee, Visserij en Biogrondstoffen, zie de PowerPointpresentatie van de werksessie (23 april 2019) in bijlage D.

\section{Deelsessie Noordzee}

De aanwezigen werden verdeeld in vier groepen die allen 20 dezelfde kennis- en innovatievragen voorgelegd kregen (zie Bijlage B, voor overzicht van de vragen). Doel van de 'pressure cooker' was om de vragen op volgorde van prioriteit te leggen. Tevens was er één leeg kaartje waarop eventueel nog een ontbrekende kennisvraag ingevuld kon worden. In de plenaire terugkoppeling werd daarna gepresenteerd wat voor elke groep de drie belangrijkste kennisvragen waren, of de 'wildcard' is ingezet en wat de belangrijkste discussiepunten waren. De verslagen van de discussies rondom de prioritering van de witte vlekken zijn per groep terug te vinden in Bijlage A: discussies werksessie. Hieronder wordt een kort overzicht gegeven van de belangrijkste terugkoppelingen. 


\section{Plenaire terugkoppeling}

\section{Groep 1}

Top 3 prioritaire vragen:

1. Basiskennis ecosysteem: welke aanpassingen zijn nodig zodat de huidige monitoringsprogramma's de vragen van de toekomst (o.a. draagkracht van het systeem) kunnen beantwoorden?

2. Grootschalige bouwwerken op zee (windparken, energie(eilanden)): Hoe brengen we de basiskennis van het fysisch, chemisch en ecosysteem op orde om effecten van ingrepen/bouwwerken te kunnen beoordelen en afwegingen te kunnen maken?

3. Mede gebruik windparken op zee: wat zijn de technische mogelijkheden en kosten-baten van voedselproductie visserij en maricultures)?

Wildcard: geen.

Is er wel voldoende wind voor alle geplande windparken? Tot 2030 wordt niet verwacht dat dit een probleem kan worden. CO2-fixatie door zeewier, gaat dit betekenis krijgen? Daar wordt aan getwijfeld, vanwege het kort-cyclisch karakter (hoewel dit volgens de definities dan wel weer als CO2-neutraal wordt gezien).

Discussie:

Discussie over grootschalige zeewierteelt op de Noordzee: hoe de "valley of death" (onrendabele top) te slechten? Zeewierteelt tot nationale doelstelling benoemen (staat inmiddels al in het klimaatakkoord). Subsidieregelingen zijn nodig voor investeerders (vergelijkbaar met regelingen voor windmolens en zonnepanelen). Financiering via PPS-en? Startende bedrijven hebben onvoldoende cashflow om in cash te kunnen bijdragen.

\section{Groep 2}

Top 3 kennisvragen:

1. Natuurversterking

Basiskennis ecosysteem ( $1 \mathrm{a}$ en $1 \mathrm{~b}$ zijn allebei basiskennis die nodig is voor begrip over balans tussen ecologie en economie)

2. Grootschalige bouwwerken - arbeidsmarkt van de toekomst?

3. Grootschalige bouwwerken - basiskennis fysisch, chemisch en ecosysteem Medegebruik windparken op zee

Wildcard: geluid.

Discussie:

De kennisvragen zijn niet gesorteerd op inhoud maar meer op balans tussen ecosysteem en economie en de basiskennis op orde krijgen. Wat is dan heel belangrijk? De details voor de balans zijn niet zo heel belangrijk. Klimaatverandering speelt op de achtergrond, waterstofopslag ook. Die zakten naar achteren in de prioritering. Waar is de groep op uitgekomen:

- Waar moet de natuur heen, wanneer is het goed en wat moet je dan gaan meten? Eerst kijken wat de plannen zijn en dan een plan maken.

- Wat willen we als maatschappij in de toekomst en wat zijn de mogelijkheden? Hoe ziet de arbeidsmarkt van de toekomst eruit? Pas als je dat op een rij hebt staan, kun je de volgende stap maken.

- Grootschalige bouwwerken op zee, daarvoor heb je basiskennis nodig van het chemisch/fysisch ecosysteem nodig.

$\mathrm{Er}$ is geen wildcard ingezet, maar onderwatergeluid is wel een belangrijk onderwerp. 


\section{Groep 3}

Top 3 kennisvragen:

1. Weerbaarheid van het ecosysteem (wildcard).

2. Grootschalige bouwwerken op zee (windparken, (energie)eilanden): hoe brengen we de basiskennis van het fysisch, chemisch en ecosysteem op orde om effecten van ingrepen/bouwwerken te kunnen beoordelen en afwegingen te kunnen maken?

3. Wind op zee: welke compenserende maatregelen kun je nemen bij het optreden van negatieve effecten op de natuur?

Wildcard: weerbaarheid van het ecosysteem.

\section{Discussie:}

De discussie was gericht op gebruik en ecosysteem als twee thema's. Als we willen begrijpen wat al die activiteiten doen met het milieu, moeten we de weerbaarheid weten van het systeem. Bijv. zeewierkweek. Dat is de wildcard geworden. We hebben indicatoren nodig om te kijken of ons systeem nog in balans is.

\section{Groep 4}

Top 3 kennisvragen:

1a. Basiskennis ecosysteem: Welke aanpassingen zijn nodig zodat de huidige monitoringsprogramma's de vragen van de toekomst (o.a. draagkracht van het systeem) kunnen beantwoorden.

Bij deze vraag focust de groep met name op basiskennis van 'de draagkracht van het systeem' - en niet zozeer hoe de huidige monitoringsprogramma's aangepast dienen te worden.

1b: Wind op zee: Is er voldoende wind om de huidige ambitie van Nederland en die van andere Noordzeelanden te kunnen realiseren (o.a. zog-effect = letterlijk elkaars wind afvangen?)

1c: Medegebruik windparken op zee: Wat zijn de technische mogelijkheden en kosten-baten van voedselproductie (visserij en maricultures)? Gekoppeld aan grootschalige inrichting op zee (2).

Wildcard: Grootschalige inrichting op zee. (Aanpassing op de kaart Grootschalige bouwwerken op zee).

\section{Discussie:}

De discussie ging vooral over dat de bovenstaande 3 onderwerpen niet los van elkaar gezien kunnen worden en als het ware een 3 -eenheid vormen dat als eerste aangepakt moet worden. Kennis is nodig over het fysisch, chemisch en biologisch systeem om wat te kunnen zeggen over het verder medegebruik van grootschalige inrichtingen op zee (niet alleen windparken op zee). Discussie blijft of Basiskennis op $1 \mathrm{~A}$ moet staan of Wind op Zee (voldoende wind) op 1A moet staan. Belangrijk is een integrale aanpak.

\section{Financieringsmogelijkheden}

De groepen gingen vervolgens aan de slag met de vraag: Hoe gaan we jullie top 3 prioriteiten financieren? Wat is jullie advies? De verslagen van de discussies rondom de financieringsmogelijkheden van de witte vlekken zijn per groep terug te vinden in Bijlage A: discussies werksessie.

\section{Plenaire terugkoppeling}

\section{Groep 1}

Er worden drie "bottle necks" gedefinieerd:

1. Fundamenteel en toegepast onderzoek (beide zijn gelijktijdig nodig, ketenaanpak organiseren).

2. Ontschotten van kennisdisciplines: ecologen moeten gaan samenwerken met technologen en vice versa.

3. Ontschotten bestuurlijke aansturing van fundamenteel en toegepast onderzoek over disciplines: ontschotting is te kunnen realiseren.

Punt 1 en 2 kunnen we organiseren, punt 3 waarschijnlijk niet: hier moeten we in eerste instantie op een slimme manier mee gaan dealen. Op langere termijn: werken aan nieuw governance model, ook qua financieringsinstrumenten onderzoek.

Ad 1 Fundamenteel en toegepast onderzoek o.a. richten op modernisering monitoringssystemen (beter, sneller). Hier kan Nederland het verschil maken. Coördinatie op verschillende niveaus nodig. 
Groep 2

Er zijn duidelijke barrières:

- Het is moeilijk om als TO2 instituut met een universiteit samen te werken. Als partner is dat vaak lastig omdat het financieel niet altijd gunstig is. Als onderaannemer is het aantrekkelijker vanuit de financiële randvoorwaarden bekeken, maar dan kun je niet meebeslissen over de organisatie en inhoud van het project.

- De ministeries hebben te maken met aanbestedingsregels en andere beperkingen waardoor het niet altijd mogelijk is om TO2 instituten en andere organisaties individueel of gezamenlijk te financieren waardoor integraal onderzoek wordt belemmerd.

Opgesplitst in 2 soorten onderzoek:

Medegebruik: publiek/privaat

Monitoring, basiskennis natuur: overheid en Ngo's. Combineren voor meer efficiëntie.

Veel mensen willen wel samenwerken. Een soort transitiefonds zou goed zijn. Dat je met een plan kunt komen en dat er een overkoepelende groep is die dat beoordeelt.

\section{Groep 3}

Internationaal kijken naar problematiek is een belangrijk onderwerp. Alle landen rondom de Noordzee moeten samenwerken om internationaal goede projecten uit te kunnen voeren.

Ook de koppeling tussen fundamenteel en toegepast onderzoek is heel belangrijk. Je kunt niet alleen fundamenteel of alleen toegepast onderzoek uitvoeren. De pilots die uitgevoerd worden (toegepast onderzoek), zijn weer input voor fundamenteel onderzoek.

Daarbij is nog een belangrijk punt: alle onderzoeken die worden uitgevoerd moeten in beeld gebracht worden. Wat is er al gebeurd, welke resultaten zijn eruit gekomen, hoe vergelijken we dit met internationaal onderzoek en wat kunnen we ermee doen? Dat zou door de ministeries uitgevoerd kunnen worden. Dan is er een overzicht van wat er allemaal speelt.

In eerste instantie lijkt PPS minder interessant, maar het is wel relevant waar innovaties worden onderzocht. Bij technologieën voor windmolenparken bijvoorbeeld. Daar zit kans voor PPS.

Voor de integratie van projecten zou een soort platform wenselijk zijn. Hierbij moet oog zijn voor integraliteit en moet versnippering tegengaan. We zouden wel weer een nieuw collectief fonds op kunnen richten, maar dat heeft gebleken niet te werken. We moeten in plaats daarvan goed gebruik maken van de huidige financiële mogelijkheden.

\section{Groep 4}

Basiskennis van het ecosysteem en het Wind op zee vraagstuk zijn fundamentele vraagstukken. Echter of er voldoende wind is om te oogsten (Wind op Zee) is de windpark exploitanten ook aangelegen. Medegebruik van windparken op zee betreft toegepast onderzoek. De NWA-call lijkt geschikt voor het Basiskennis ecosysteem onderzoek; aandachtspunten zijn daarbij de benodigde interne financiering van kennisinstituten om tegen tarieven aan te zetten en dat het lastig is om faciliteiten in gebruik te namen omdat deze kosten (meestal) niet vergoed worden. BANOS (opvolger van BONUS) zou geschikt kunnen zijn voor het Wind op Zee vraagstuk.

Voor technische, toegepaste onderzoeken zou een PPS in theorie wel kunnen. Vanuit de industrie (vooral wind) moet er dan wel wat inzitten voor hen. Bijvoorbeeld via verplichtingen in kavelbesluiten om bij te dragen aan fundamentele onderzoeksvragen, beschikbaar stellen van eigen data en/of verplichting om meerdere disciplines te betrekken.

Internationale samenwerking is nodig met andere Noordzeelanden. Wederom is een integrale aanpak heel belangrijk.

Overig advies omtrent financieringsmogelijkheden betrof:

- faciliteer integrale financiering over verschillende sectoren heen - om samenwerking tussen verschillenden sectoren makkelijker te maken binnen onderzoeksprojecten. 
- Inzet van innovatiefonds/transitiefonds $(15 \mathrm{mln})$ voor het mitigeren van effecten van windparken op zee - nu lijkt de focus alleen te liggen bij visserij en natuur - trek het breder.

- Bij aanbesteding van windparken - eisen dat een $x \%$ onderzoek gedaan wordt aan fundamenteel onderzoek om basiskennis vragen te kunnen beantwoorden.

- Het kunnen combineren van verschillende TKI programma's - cross-over programma's waarin sector en kennisinstituten makkelijker samen kunnen werken.

\section{Deelsessie Voedsel \& Biogrondstoffen}

De aanpak van de prioritering volgt dezelfde lijn als de sessie Noordzee. De verslagen van de discussies rondom de prioritering van de witte vlekken zijn per groep terug te vinden in bijlage A: discussies werksessie. De kennis- en innovatievragen die aan de groepjes werden voorgelegd zijn te vinden in bijlage $\mathrm{C}$.

Plenaire terugkoppeling

Groep 1 (Biogrondstoffen)

Tijdens de discussie zijn de hoofdonderwerpen van Biogrondstoffen (zeewierkweek) op volgorde doorlopen.

- Wet- en regelgeving (inrichting windparken): tot aan 2023 wordt het lastig om in de tenders die nu al uit zijn, zeewierkweek opnemen. Pas bij volgend kabelbesluit kan er rekening gehouden worden met de in-field kabels.

- Ecosysteem (draagkracht): $14.000 \mathrm{~km}^{2}$ heel groot getal. Eerder 100 à $200 \mathrm{~km}^{2}$. Ongeveer 25\% beschikbaar van het windpark. INTA belangrijk.

- WUR-zaken (teelt, veredeling): al veel ingevuld door WUR.

- Economische onderdelen (business case): één van de onderwerpen is hoe je door de 'valley of death' komt. Opschaling van zeewierkweek.

Wildcard: niet ingezet.

\section{Groep 1 (Visserij)}

De input voor prioriteiten is:

- Proces tot innovatie: efficiency. Innoveren in de sector.

- $\mathrm{Er}$ is kennis nodig van het bodemecosysteem om bodemberoering te verminderen. Bijv. belangrijke gebieden: hek er omheen en sluiten voor visserij.

- Bij pulsvisserij werd het te veel een Nederlands verhaal. Er is meer interactie nodig met Europese landen. Meer integratie binnen Europa, samenwerken met andere landen zodat we samen aan oplossingen denken.

Wildcard: niet ingezet.

\section{Groep 2 (Visserij)}

Top 3 kennisvragen

Goede boterham:

1. Innovatie in de sector stimuleren - om levensvatbaarheid van de sector te ondersteunen.

2. Inpasbaarheid en medegebruik van de visserij in geplande ontwikkelingen op zee (incl. andere visserij vormen)

3. Inzicht in socio-economisch effecten van geplande ontwikkelingen op zee en de impact op de visserij (incl. uitkoopregeling)

Wildcard: geen wildcard ingezet.

Discussie: binnen de sector moet geïnnoveerd worden om te kunnen anticiperen op de toekomst. Het is daarom van belang dat innovatie ook plaatsvindt en gestimuleerd wordt. De vraag is echter welke kant moet er geïnnoveerd worden? Hoe de visserij in te passen tussen de andere ontwikkelingen op zee is van belang om een toekomst te hebben op de Noordzee - hierbij moet niet alleen gekeken worden naar bestaande visserijmethoden maar ook naar nieuwe visserijtechnieken en welke kansen er liggen op de nieuwe Noordzee. Als er dan een keuze is gemaakt in welke richting de visserijsector zich wil gaan 
ontwikkelen zal gekeken moeten worden wat daarvan de socio-economische gevolgen van zijn. Bovenstaande vragen zijn belangrijk om helder te hebben t.b.v. een lange termijn visie van de sector.

\section{Top 3 kennisvragen}

Verbeterde arbeidsomstandigheden:

1. Innovatie vistuig i.c.m. Optimaliseren verwerkingsproces

2. Inzicht inzet buitenlandse werknemers

3. Inzicht in de gevolgen van de visserij transitie

Wildcard: geen wildcard ingezet.

Discussie: innovatie van het vistuig i.c.m. optimalisatie van het verwerkingsproces worden gezien als de topprioriteiten als het gaat om verbeterde arbeidsomstandigheden - hierbij kan gelijk gekeken worden naar dierwelzijn en mogelijke andere aspecten. Inzicht inzet buitenlandse werknemers vindt de groep belangrijk om te komen tot een gelijk "level-playing field" - maar ook voor de veiligheid van de werknemers. Omdat het ook veiligheid betreft wordt deze kaart als tweede prioriteit bestempeld boven prioriteit 3. Inzicht in de gevolgen van de visserij transitie op de arbeidsmarkt en de benodigde toekomstige vaardigheden die vissers nodig zullen hebben om te kunnen blijven vissen/werken in de toekomstige Noordzee wordt als belangrijk gezien door de groep.

Groep 3 (Visserij)

Top 3:

1. Selectiviteit: vangen van de vissen die je wil vangen en niet de andere vissen.

2. Kennis van visgedrag: wat doen de vissen in het vistuig, voor het vistuig, als het schip aankomt, etc. Hoe kun je op basis daarvan de juiste vissen vinden? Maar ook visgedrag als in migraties. Ten tweede, wat kun je met deze kennis? Daarmee kun je motivatie initiëren bij de visserij om innovatief te kunnen werken. Dat moet echter wel kunnen, zowel financieel als volgens regelgeving. En als laatste, als je een innovatie hebt, dan zou je deze ook moeten kunnen implementeren.

3. Dierenwelzijn: kwaliteit van leven zoals het dier het zelf ervaart. Belangrijk om te onderscheiden. Balans tussen positieve en negatieve balans. Bij visserij bereiken we die balans niet, maar we kunnen wel de negatieve effecten verminderen. Hoe het systeem precies in elkaar zit, weten we nog niet. Dat moeten we eerst weten: systeemanalyse. Gedragsverandering is hierbij ook wel erg belangrijk.

\section{Financieringsmogelijkheden}

Vervolgens worden de groepen gevraagd antwoord te geven op de volgende vraag: Welke van de prioriteiten lenen zich voor publiek-private samenwerking (PPS)? En welke partijen zijn dit dan?

De verslagen van de discussies rondom de financieringsmogelijkheden van de witte vlekken zijn per groep terug te vinden in Bijlage A: discussies werksessie.

\section{Plenaire terugkoppeling}

Groep 1 (Biogrondstoffen)

PPS zal lastig zijn. Kleine bedrijven zijn vaak wel geïnteresseerd maar hebben de middelen niet. Grote bedrijven nog niet geïnteresseerd. In het begin zal er overheidsgeld nodig zijn.

Nationale doelstelling om een bepaalde hoeveelheid te halen zou wel helpen.

\section{Groep 1 (Visserij)}

-Emissie: waterstofopslag

-Bodemberoering:

Pre-traject (ontwikkeling tuig) wordt vaak door overheid gesubsidieerd. Andere opties:

- Investeringsfonds oprichten. Bedrijven zoeken die erin willen investeren.

- Patent aanvragen op innovaties. Dan kan iedereen erbij maar wel tegen betaling.

- Groep vissers abonnement nemen op data en daaraan toevoegen en daar ook vanaf halen. 


\section{Groep 2 (Visserij)}

Inzicht in de inzet van buitenlandse werknemers, de socio-economische effecten van ontwikkelingen op zee op de visserijsector en de arbeidsmarkt zijn kennisvragen die niet geschikt zijn als PPS en zullen dus publiek gefinancierd moeten worden.

PPS zouden mogelijk kunnen zijn omtrent optimaliseren van het vistuig en het verwerkingsproces aangezien dat meerdere doeleinden kan hebben vb. dierwelzijn, arbo. Optimalisatie van het verwerkingsproces ( $\mathrm{vb}$. Camera detectie) kan ook bijdragen aan het monitoren van visbestanden. Waardoor het zowel voor de sector als de maatschappij van belang is. Hierdoor zou het juist geschikt zijn voor een PPS (zowel privaat maar ook publiek). PPS omtrent het stimuleren van innovatie en inpasbaarheid in de toekomstige Noordzee is een mogelijkheid maar dan moet het een economisch voordeel brengen voor ondernemers.

Belemmeringen van PPS voor visserij: In topsector call moet de visserijsector $50 \%$ bijleggen, dit is niet aantrekkelijk voor visserijondernemers. Daarnaast is het vele papierwerk/administratieve last dat bij (Europese) regelingen komt kijken vaak een belemmering voor vissers om er gebruik van te maken.

\section{Groep 3 (Visserij)}

Selectiviteit: PPS niet zo geschikt. Misschien als je naar visgedrag kijkt in relatie tot vistuig (innovatie), dan zouden vissers en PPS misschien wel willen bijdragen.

Vismigratie bijv. meer publieksgeld.

Voor radicale herziening zal er publiek-privaat nodig zijn. Eén visserman zal hier niet alleen aan bijdragen. Een idee voor de private bijdrage is, is dat het collectief zou kunnen.

Verbeteringen in bedrijfsvoering, proces efficiënter te laten verlopen.

Bij gedragsverandering meer te zoeken in opleiding.

\section{Afsluiting}

Vervolgtraject:

- Verslag wordt naar alle deelnemers gestuurd.

- Werksessie Community of Practice (CoP) meervoudig ruimtegebruik Noordzee (14 mei).

- 30 juni zullen de eindrapportages van de programmeringsstudies aan LNV opgeleverd worden.

\section{Opmerkingen/hartenkreten}

- De vragen moeten eerst geclusterd worden. Denk goed na over het organiseren van de kennisvragen. Onderscheid alvast of ze meer fundamenteel of toegepast zijn.

- We hebben het nu over de zee gehad, maar niet over rivieren en oceanen. De andere twee zitten er wel degelijk in maar voeren veel minder de boventoon. Zou fijn zijn om daar ook een soort aanbeveling voor te hebben. Valt echter buiten de scope van deze programmeringsstudies.

- Veel gehad over voedsel en energie op zee. Het is ook goed om na te denken over transport op zee. Scheepsvaart/luchtvaart en hoe dat in relatie staat tot wat we vandaag besproken hebben.

- Hoger niveau bekijken dan alleen Nederland, meer internationaal gaan oppakken. De vraagstukken zijn immers internationaal.

- Het is een verschil of er helemaal geen kennis is of dat er wel wat kennis van is om er alvast iets mee te kunnen doen. Bijvoorbeeld van ecosysteem ontbreekt veel kennis, maar wat weten we wel al. Het zou handig zijn om het iets meer uit elkaar te trekken.

\section{Bijlage A: Discussies werksessies}

\section{Noordzee: witte vlekken}

\section{Groep 1}

Deze groep begon met een discussie over de samenhang tussen de verschillende vragen. Als methode hebben we de onbelangrijke vragen gesplitst van de belangrijke, waarna deze zijn geprioriteerd, uitgaande van een toekomstvisie 'goede balans ecologie-economie'. Fundamentele vragen, zoals 'goede monitoring' en het 'begrijpen van het systeem' werden gezien als een belangrijke basis. Er was discussie over of je eerst zou moeten definiëren waar het systeem heen moet (wensbeeld), voordat je probeert de monitoring te verbeteren, of dat je het andersom zou moeten doen (kip-ei). De meer praktische 
vragen over inpasbaarheid van grote structuren, kregen minder prioriteit. Een ander belangrijke vraag is hoe de arbeidsmarkt er in de toekomst uit zal komen te zien. Samengevat: Als eerste is belangrijk wat je visie is: waar moet de natuur heen. Wat voor een metingen heb je nodig. Als tweede is belangrijk: hoe ziet de arbeidsmarkt eruit. Als derde moet je kijken hoe je de grootschalige bouwwerken kunt inpassen. Minder belangrijk voor de missie: effecten van klimaatverandering en het verkeersbeeld.

\section{Groep 2}

Tijdens het prioriteren is besloten om iedereen één vraag uit te laten kiezen die voor hem/haar prioriteit heeft. Zodoende kwamen er al 8 vragen naar voren die prioriteit hebben. Vervolgens zijn deze 8 getracht op volgorde te leggen. Hierin zaten echter wat subvragen waardoor er wat grotere categorieën ontstonden.

Er was al snel een algemeen beeld dat het verkeersbeeld wel belangrijk is, maar geen prioriteit heeft. Het zou ook deels door MARIN opgepakt worden. Ook natuurversterking wordt al snel naar onderen geschoven. Het ligt wel ten grondslag aan veel andere vragen, maar wordt niet gezien als de belangrijkste.

Al snel kwam het idee voor de wildcard: de weerbaarheid van het systeem. Is het geheel nog in balans of staat het op het punt van omvallen? Wat kunnen we wél en niet doen met de Noordzee? Zijn we het aan het overbelasten, waar ligt de grens? Draagkracht! Dat is een fundamentele vraag. Dit is ook los te zien van klimaatverandering.

Het blijkt zeker niet eenvoudig om de 8 belangrijkste kaartjes op volgorde te leggen. Uiteindelijk komen we min of meer tot 2 soorten vragen. Namelijk vragen gericht op:

1. Ecosysteem/evenwicht: basiskennis van het ecosysteem. Idee hierbij is dat de toekomstige activiteiten samen zullen moeten gaan met een evenwichtige natuur.

2. "Economie": gebruik op zee, o.a. medegebruik wind op zee, grootschalige bouw. De vraag hierbij is óf en hoe grootschalige bouwprojecten gaan plaatsvinden. Wat gaat er gebeuren en wat zijn de gevolgen hiervan?

$\mathrm{Er}$ is duidelijk verdeeldheid in de groep. Basiskennis het belangrijkste volgens sommigen, volgens anderen is dat geen prioriteit maar is het medegebruik en grootschalige bouwwerken op zee prioriteit (hieronder werd ook waterstofopslag genoemd, waar TKI mee bezig zou zijn). Uiteindelijk wordt besloten om te stemmen. 4 stemmen voor basiskennis als belangrijkste thema en 3 stemmen voor medegebruik.

Uiteindelijk ligt er een top 7 waar (vrijwel) iedereen zich in kan vinden. De overige vragen liggen iets minder op volgorde maar zijn meer als clusters geplaatst.

\section{Groep 3}

Geen verslag.

\section{Groep 4}

Groep 4 begon met het doorlezen van de verschillende kennisvragen. De discussie begon met het uitlichten van één van de kennisvragen wat volgens één deelnemer een prioriteit moest zijn. Het betrof de kennisvraag of er wel voldoende wind is om te oogsten om de huidige ambitie van Nederland en van andere Noordzeelanden te kunnen realiseren. Meerdere deelnemers van de groep konden zich hierin vinden, echter aangegeven werd dat twee andere vragen hier sterk aan gekoppeld waren, nl. de kennisvraag Basiskennis van het ecosysteem (fysisch, chemisch, biologisch) en de kennisvraag Medegebruik windparken op zee. Er volgde een discussie over welke van deze drie vragen de prioriteit 1,2 en 3 kregen. Uiteindelijk werd besloten dat deze 3 onderwerpen niet los van elkaar bekeken kunnen worden, en als het ware een 3-eenheid vormen dat als eerste opgepakt moeten worden. Kennis is nodig over het fysisch, chemisch en biologisch systeem om wat te kunnen zeggen over het verder medegebruik van grootschalige inrichtingen op zee (niet alleen windparken op zee). Er bleef onenigheid over de vraag of Basiskennis of Wind op Zee (voldoende wind) op $1 \mathrm{~A}$ moest staan. Ingeschat werd dat mocht men nu starten met het onderzoek naar Basiskennis Ecosysteem de resultaten over ongeveer 5 jaar beschikbaar zouden zijn. 
Om op korte termijn datgene dat moet gebeuren in goede banen te leiden werd geopperd dat dan ingezet moet worden op het verminderen van emissies van de vloot onderhoudsschepen van windturbines, aangezien die vloot mogelijk aanzienlijk kan worden. Hier werd tegenover geplaatst dat juist onderzoek naar grootschalige bouwwerken op zee (windparken, (energie) eilanden) (hoe brengen we de basiskennis van het fysisch, chemisch en ecosysteem op orde om effecten van ingrepen/bouwwerken te kunnen beoordelen en afwegingen te kunnen maken?) een hogere prioriteit heeft omdat dat bepaald hoeveel activiteit op zee kan plaatsvinden en dus ook hoe groot de onderhoudsvloot is. Het gaat daarbij niet alleen om grootschalige bouwwerken, maar om grootschalige inrichtingen op zee ( $\mathrm{vb}$. Voedselproductie op zee zoals zeewier). De kennisvraag over hoe de effecten van ingrepen en bouwwerken te kunnen beoordelen en afwegingen te kunnen maken werd als prioriteit 2 bestempeld.

De opmerking werd geplaatst dat de effecten van Klimaatverandering nu niet als een prioriteit werd genoemd, terwijl het wel van belang is om duidelijk te hebben hoe klimaatverandering effect zal hebben op het ecosysteem van de Noordzee en de vispopulaties, maar ook de mogelijkheden in de Noordzee i.r.t. Wind op Zee. Aangegeven werd dat dit onderzoek al opgepakt werd door Wageningen Economic Research.

Door de tijdslimiet werden de andere kennisvragen niet geprioriteerd.

\section{Noordzee: financieringsmogelijkheden}

\section{Groep 1}

De groep benoemde als grote barrière dat er geen partnerschappen mogelijk zijn tussen onderzoeksinstituten (TO2) en universiteiten, vanwege verschillende financieringsregels. Bij NWO-calls kun je bv. geen TO2 mensen inhuren, terwijl NWO wel dat soort ervaren mensen zoekt voor bepaalde programma's. En ook partnerschappen tussen universiteit en bedrijfsleven zijn lastig. Vanuit opdrachtgeverschap (overheid/RWS) loop je aan tegen de complexiteit van aanbestedingsregels, waardoor gebundelde vragen bv. niet uitgezet kunnen worden als een geheel (i.v.m. raamcontracten, goedkoopste bieder, etc.). Een ander probleem is dat het nu lastig om kleine bedrijfjes in te zetten (bijv. .specialisten op gebied van Artificial Intelligence). TU Delft pleit voor het opzetten van onderzoeksprogramma's, voordat financiering in beeld komt, daar hebben ze goede ervaringen mee. Als je met inspirerende (radicale) vragen komt, die veel belangstelling trekken, dan krijg je vanzelf de grote bedrijven achter je. Voorbeeld is een project waarbij het bedrijfsleven in de rij stond om mee te financieren.

$\mathrm{Na}$ het benoemen van de barrières ging de discussie verder over wie welk onderzoek zou moeten betalen. De groep was het erover eens dat de basiskennis (abiotiek, biotiek) door de overheid gefinancierd zou moeten worden. Tegelijk wordt in de private sector (bv offshore wind) veel informatie verzameld die niet openbaar gebruikt kan worden. Er werd gepleit voor een systeem waarbij private partners verplicht bepaalde gegevens zouden moeten delen. De overheid zou dat kunnen eisen. Over financiering van onderzoek naar de arbeidsmarkt was de groep verdeeld. Als compromis werd besloten dat zowel overheid als bedrijfsleven zouden moeten bijdragen. Daarbij is de vraag, vanwege private financiering, of je wel het juiste antwoord krijgt op de juiste vraag. Een transitiefonds kan ingericht worden waarin de offshore windmolenboeren geld kunnen inleggen, om zo gemeenschappelijke projecten te financieren.

\section{Groep 2}

Doel van deze sessie was het bediscussiëren van de financieringsmogelijkheden van de top 3 kennisvragen.

Al snel wordt gezet dat de stap naar financieringsmogelijkheden toe een snelle stap is. Slaan we de tussenstap niet over? Het is belangrijk te weten welke samenwerkingsverbanden er zouden kunnen zijn. Als je eerst kijkt naar de financiering, zou je misschien versnippering krijgen. Financiering kun je daarna ook nog op een innovatieve manier verwerven. Bijvoorbeeld door het afdragen van $€ 0,01$ per $\mathrm{km}$ gevaren op Noordzee die vervolgens in een pot verzameld wordt. 
Iedereen is het erover eens: we zoeken integratie voor de Noordzee. Maar we kunnen niet weer een nieuwe methode bedenken. Dat is al vaker geprobeerd maar loopt altijd weer uit op losse initiatieven. Integraliteit is heel belangrijk. Genoemd wordt dat de ministeries hierin een belangrijke rol zouden moeten/kunnen spelen. Zij zouden geld kunnen beheren dat met andere financieringsmogelijkheden wordt uitgezet. Op dit moment komen maatschappelijke problemen naar voren, iedereen wil er in investeren. Waar echter niemand in investeert, is dat er een soort platform komt, die integratie. En dat is nou juist zo belangrijk. Een platform wordt als voorbeeld genoemd. Dat zou eigenlijk een onderwerp op zich zijn. Belangrijk dat hier wel aandacht aan wordt besteed zodat het niet alsnog versnippert.

Over het soort onderzoek is ook niet een eenduidig antwoord te vinden. Er is namelijk een wisselwerking nodig tussen fundamenteel en toegepast onderzoek. Je ziet dingen in de pilots die worden uitgevoerd, waar dan weer fundamenteel onderzoek uit voortkomt. Je leert vanuit pilots en daar koppel je dan een fundamentele vraag aan: Community of Practice.

Ander belangrijk punt dat naar voren komt is de internationale samenwerking van Noordzeelanden. Voornamelijk ook bij windparken, waar ook in andere Noordzeelanden veel aandacht voor is. Al deze ecosysteemvragen moeten op Noordzeeschaal worden toegepast. Subsidie als BANOS zou hiervoor interessant kunnen zijn om met meerdere landen samen te werken. Dan heb je alleen volgend jaar geen antwoord. Ook Horizon Europe is hiervoor een goed voorbeeld.

Rondom Wind op Zee lopen al verschillende onderzoeken. Soort programma is WOZEP. Vanuit één plek ontsloten. Je zou hierbij ook meer fundamenteel onderzoek bij willen doen. Hieronder vallen verschillende onderzoeken die onder verschillende financieringen kunnen vallen. Je kunt hier járen aan werken. Je moet deze ook op grote schaal bekijken, dus meerdere windparken samen.

Ministeries bij uitstek hebben belang bij dit onderzoek. Hiervoor zouden zij een goede financieringsbron zijn, mits zij daarbij ook belang hebben. Als ze ook bekijken wat er al aan onderzoek gedaan is en wat er nog zou kunnen gedaan worden, dan kunnen er concrete vraagstukken aan het licht gebracht worden. Concrete innovatieprogramma's kunnen sneller PPS'en tot stand laten komen. Dat kan bij deze top 3 vragen minder. Bedrijven en Industries hebben hier zelf waarschijnlijk weinig baat bij.

De timing is ook heel belangrijk. Om mee te liften moet je goed weten wanneer er wat op het pad komt. Dat je op tijd kunt beginnen met je project. Dat je dus als projectteam samen een voorstel indient. Langjarige projecten zouden beter zijn als je tussentijds resultaten zou moeten laten zien, maar niet telkens opnieuw een voorstel in moet dienen. Dus bijv. 15-jarig programma en dat je elke 3 jaar de resultaten terugkoppelt maar daarna wel meteen weer door kunt met het programma. En niet weer opnieuw een voorstel in moet dienen in de hoop op verlenging.

\section{Groep 3}

De groep werd gevraagd om aan te geven in hoeverre de prioriteit kennisvragen fundamenteel of toegepast onderzoek betrof en in hoeverre de vraag zich leende voor een PPS-constructie.

De groep was het overeen dat de kennisvragen over Basiskennis ecosysteem fundamenteel onderzoek betrof. Deze vraag zou opgepakt kunnen worden als een NWA-voorstel. Aandachtspunten hiervoor waren wel dat interne financiering van kennisinstituten nodig is om tegen uurtarieven aan te zetten. Daarnaast werd opgemerkt dat het lastig is om faciliteiten in gebruik te nemen voor onderzoek omdat deze kosten meestal niet vergoed worden.

De kennisvraag of er voldoende wind is om te oogsten om te komen tot de ambities van Nederland en andere Noordzeelanden werd ook beoordeeld als een fundamentele kennisvraag, maar één waarvan de resultaten ook van groot belang zijn voor de exploitanten.

Medegebruik van windparken op zee betreft toegepast onderzoek. Het programma BANOS (Baltic and North Sea Coordination and Support Action; opvolger van BONUS) werd aangegeven als een financieringsmogelijkheid. TO2 instituten zouden hier gebruik van kunnen maken criteria moeten nog voor het BANOS-programma worden nog nader uitgewerkt. 
De groep noemde het volgende aanvullend advies omtrent financieringsmogelijkheden:

- Faciliteer integrale financiering over verschillende sectoren heen - om samenwerking tussen verschillenden sectoren makkelijker te maken binnen onderzoeksprojecten.

- Inzet van innovatiefonds/transitiefonds $(15 \mathrm{mln})$ voor het mitigeren van effecten van windparken op zee. Nu lijkt de focus alleen te liggen bij visserij en natuur, trek het breder.

- $\quad$ Bij aanbesteding van windparken eisen dat een $x \%$ onderzoek gedaan wordt aan fundamenteel onderzoek om basiskennis vragen te kunnen beantwoorden.

- Het kunnen combineren van verschillende TKI-programma's. Realiseren van cross-over programma's waarin sector en kennisinstituten makkelijker samen kunnen werken.

- Hoe bedrijven verleiden mee te betalen?

- Via kavelverplichtingen - verplichtingen opnemen zoals onderzoekvragen oppakken en/of beschikbaar stellen van verzamelde data verzameld. Opnemen als selectiecriteria voor de tenders.

- Verplichting om meerdere disciplines te betrekken en mee in gesprek te gaan (uit je eigen bubbel stappen).

\section{Visserij: witte vlekken}

\section{Groep 1}

Er lag een groot aantal vragen op tafel, verdeeld over 'minder emissies', 'minder bodemberoering', en nog een viertal 'overige vragen'. Ook hier werden de vragen eerst gegroepeerd, daarna geprioriteerd. De groep discussieerde allereerst over de inpassing van de visie en de vragen onder het Gemeenschappelijk Visserijbeleid (GVB): zonder andere landen kun je niks. De puls is een voorbeeld waarbij een illegaal vistuig is ontwikkeld, dat niet werd omarmd door de overige landen. Je moet zorgen dat datgene wat ontwikkeld wordt, ook gebruikt kan worden. LNV stelt dat we op het gebied van landbouw een voortrekkersrol hebben. Dat zou bij visserij ook kunnen. Je moet je vanaf het begin bezinnen hoe je het inbouwt en geaccepteerd krijgt.

Veel vragen op tafel gingen over deelaspecten, maar de groep was het erover eens dat een belangrijk gemeenschappelijke deler was: zorgen voor een hogere efficiëntie. Efficiency kan dienen als politiek wapen (stok achter de deur). De efficiëntie gaat over alle aspecten: uitstoot (uitstoot/kg vis), bodemberoering (per kg vis), bijvangst, selectiviteit, etc. En dat betekent dat bv. commerciële vispopulaties niet op basis van Maximum Sustainable Yield (MSY) worden geoogst, maar op basis van meerdere criteria. Dit kan betekenen dat de populatiegrootte veel hoger moet zijn (i.p.v. MSY).

Samengevat waren de belangrijkste thema's:

1. GVB \& efficiency

2. habitatstudies rondom kwetsbaarheid.

3. inpassing in de politiek

\section{Groep 2}

De groep werd gevraagd kennisvragen omtrent Arbeidsomstandigheden en het kunnen blijven verdienen van een Goede boterham rekening houdend met de andere 5 aspecten van een duurzame visserij. De groep begon met de kennisvragen omtrent 'Goede boterham'. Deze kaarten werden 1 voor 1 voorgelezen waarna de groep besloot of de kennisvraag een lage, midden of hoge prioriteit had.

- Inzetten op hightech visserij - groep is er overeen dat deze vraag in het midden valt.

- Optimalisatie van de organisatie van de visserijsector op NL niveau - discussie wordt gehouden dat deze verantwoordelijkheid bij de sector zelf ligt. Echter in de huidige situatie zijn er verschillende PO's en verschillende metiers met andere belangen. Heeft de overheid hierbij een rol? Zo organiseren dat de sector in kan zetten op keteninnovatie. Betere organisatie zou kunnen leiden tot een sterkere sector. Deze kennisvraag wordt geparkeerd.

- Inzicht kostenbesparing mogelijkheden voor visserij - komt overeen met de levensvatbaarheid van de sector zonder subsidie (Innovatie in de sector stimuleren). Vraag hierboven betreft een organiseren vraag en deze kaart betreft een proces vraag. Wat zijn de kosten? Hoe stimuleer kostenbesparing? Dit betreft een kennisvraag. 
- Inzicht ecologische effecten van geplande ontwikkelingen op zee en de impact op de visserij Hiervoor moet je eerst weten wat de ontwikkelingsweg is voor de visserij. Wordt beoordeeld als niet de hoogste prioriteit (midden).

- Inpasbaarheid en medegebruik van de visserij in geplande ontwikkelingen op zee (inclusief andere visserij vormen), de groep is het overeen dat dit erg belangrijk om helder te hebben, om ervoor te zorgen dat de visserijsector nog goed kan verdienen.

- Hoe kan de opleiding/omscholing van vissers bijdragen aan de inpasbaarheid van de visserij op de Noordzee? - De opmerking wordt geplaatst dat men niet kan verwachten dat vissers zich om laten scholen tot boer op zee, daarnaast kun scholing pas geregeld worden wanneer duidelijk is waar de visserij naar toe gaat (lange termijn visie). Binnen het vak visserij kun je echter ook denken aan leren over anticiperen op de ontwikkelingen in de sector en in de maatschappij. Deze vraag wordt niet als een prioriteit gezien.

- Socio-economische en ecologische uitkomsten van consolidatie in de vloot. De groep noemt de potentiele ontwikkeling van 300 familiebedrijven naar 5 à 6 grotere bedrijven - hoe zou samenwerking tussen sector en overheid er dan uitzien? Belangrijk is om inzicht te hebben in wat men wil met de visserijsector? Afhankelijk daarvan weet men wat er nodig is aan sociaaleconomisch beleid. De groep is overeen dat een dergelijke socio-economische vraag aangestuurd dient te worden vanuit de overheid.

- Inzicht socio-economische effecten van de geplande ontwikkelingen op zee en de impact op de visserij - (inclusief uitkoop). De socio-economische effecten scoren hoger als kennisvraag in de groep dan de ecologische effecten wanneer het gaat om een goede boterham verdienen.

- Afwegingen ecologische duurzaamheid en economisch belang van kleinschalige visserij? - wordt niet als topprioriteit gezien.

- Mogelijkheden om de innovatiekosten door te berekenen naar de consument door een hogere prijs voor duurzame vis - Ja - deze kaart scoort hoog omdat het niet alleen helpt de visser te innoveren en gecompenseerd te worden voor hun inzet maar het draagt ook bij aan de ecologie. Hoe kan men verwachten dat de visser gaat innoveren, als zij niet de (financiële) ruimte hiervoor krijgen?

- Wildcard 1 discussie - bediscussieerd wordt of een wildcard ingezet moet worden m.b.t. het stimuleren van de productie van wilde vis bijvoorbeeld door het ontwikkelen van habitat voor kabeljauw in windparken bijvoorbeeld- om de productie van kabeljauw te verhogen zodat er meer op gevist kan worden. Geconcludeerd wordt dat deze optie kan vallen onder de kaart Inpasbaarheid en medegebruik van de visserij in geplande ontwikkelingen op zee.

- Wildcard 2 discussie - bediscussieerd wordt of de optie van een uitkoopregeling niet toegevoegd moet worden. De vraag is dan wel hoeveel van de vloot moet dan uitgekocht worden? Wat zijn dan de socio-economische gevolgen voor de visserij? Geconcludeerd wordt dat de optie Uitkoopregeling onderdeel is bij de socio-economische effecten van de ontwikkelingen op zee.

- Innovatie in de sector stimuleren - wordt door de groep gezien als belangrijk.

Conclusie - Goede boterham:

1. Innovatie in de sector stimuleren - om levensvatbaarheid van de sector te ondersteunen.

2. Inpasbaarheid en medegebruik van de visserij in geplande ontwikkelingen op zee (incl. andere visserij vormen)

3. Inzicht in socio-economisch effecten van geplande ontwikkelingen op zee en de impact op de visserij (incl. uitkoopregeling)

De kennisvragen omtrent Arbeidsomstandigheden zijn minder in aantal dan de kennisvragen Goede boterham. In verband met de tijdslimiet beoordeeld de groep de kaarten door de kaarten eerst zelf door te lezen en vervolgens te bediscussiëren welke kennisvragen volgens hen prioriteit hebben.

Innovatie van het vistuig i.c.m. optimalisatie van het verwerkingsproces worden gezien als de topprioriteiten als het gaat om verbeterde arbeidsomstandigheden - hierbij kan gelijk gekeken worden naar dierwelzijn en mogelijke andere aspecten. Inzicht inzet buitenlandse werknemers vindt de groep belangrijk om te komen tot een gelijk "level-playing field" - maar ook voor de veiligheid van de werknemers. Omdat het ook veiligheid betreft wordt deze kaart als tweede prioriteit bestempeld boven Inzicht in de gevolgen van de visserij transitie voor de arbeidsomstandigheden. Inzicht in de gevolgen van de visserij transitie op de arbeidsmarkt en de benodigde toekomstige vaardigheden die vissers nodig 
zullen hebben om te kunnen blijven vissen/werken in de toekomstige Noordzee wordt als belangrijk gezien door de groep.

Conclusie - Arbeidsomstandigheden

1. Innovatie vistuig i.c.m. Optimaliseren verwerkingsproces

2. Inzicht inzet buitenlandse werknemers

3. Inzicht in de gevolgen van de visserij transitie

\section{Groep 3}

Dierenwelzijn

Definiëring van dierenwelzijn door Hans van der Vis (expert op dit gebied bij WUR):

Kwaliteit van leven zoals het dier het zelf ervaart.

- Dierenwelzijn en visserij zijn vreemde combinatie: een schip kan gezien worden als een slachthuis (dodingsmethodes zijn vaak onverdoofd) > doel in dit verband is beperken van de scherpe randjes, dus het minimaliseren van eventuele pijn en stress bij vissen.

- Dierenwelzijnsmogelijkheden in kweekvis zijn wellicht groter. Echter hier het probleem dat wilde vis gevangen moet worden om de kweekvis te voeren. Bovendien ook vragen over de onder andere de beschikbare ruimte in de kooi.

- Wat is een witte vlek en heeft prioriteit?

- Verminderen van bijvangst is een belangrijk begin. Wanneer je ze niet vangt heb je ook geen zorgen over het dierenwelzijn

- Andere aanvulling: niet zo zeer bijvangst maar juist letsel voorkomen (ook van bijvangst). Hierdoor ook grotere overlevingskans van bijvangst.

- Ook belang van onderzoeken diervriendelijke verdovingstechniek

- Veel discussie over het leed van vissen die levend worden geslacht. Wordt door deelnemers aangewezen als een van de prioriteiten.

- $\quad$ Ekofish Group is een van de enige bedrijven die nadenkt over verdoven

- Certificaten van dierenwelzijn voor kweekvis bestaan reeds, maar niet voor wilde vis. Dierenwelzijnscertificaat is pas nodig/nuttig wanneer er bewustzijn is onder de consumenten

- Bewustzijn onder consumenten wordt genoemd als mogelijke wildcard

- $\mathrm{Nu}$ dus belangrijker dat bijvangst wordt verminderd en diervriendelijker verwerkingsproces

- Opnieuw discussie over certificaten:

- Er bestaan reeds certificaten over duurzaam vangen. Geen nieuw label introduceren, maar eerder uitbreiden van bestaande certificaten is de conclusie van de deelnemers.

- Discussie over pijn bij vissen: ze hebben een vorm van bewustzijn, maar lastig pijn te onderzoeken door onder meer de andere hersenstructuur. Het is daarom veel beter om eerst gewoon minder bijvangst te krijgen en een beter verwerkingsproces te ontwikkelen dat minder pijnlijk is i.p.v. jaren te verspillen aan onderzoeken naar pijngrens en bewustzijn van vissen (en gedurende deze tijd de huidige dodingsmethodes niet aan te passen).

- Juist een systeemanalyse doen van dierenwelzijn in vangst en verwerking.

- Wederom discussie over stress bij vissen en bijvangst en overlevingskansen. Twee biologen leggen uit dat dit soort afhankelijk is en dus heel erg complex.

- De wildcard gebruiken met als focus een mogelijk alternatief voor visvangst. Kweekvis wordt genoemd door een van de deelnemers: echter deskundigen wijzen op het feit dat je hiervoor wel vis moet vangen om de kweekvis te voeren.

- Conclusie

- Top 3

- 1 : Systeemanalyse dierenwelzijn in het vangst en verwerkingsproces

- Belangrijkste want dit is het geheel

- 2: Vermindering van letsel en mortaliteit bijvangst

- 3: Gedragsverandering bij vissers

- Leidt tot meer bewustzijn en nadenken onder de vissers 
- Veel discussie over dit punt: twijfel over de conservatieve houding van de vissers en bereidheid om aan te passen. Deelnemer suggereert dat het makkelijker is om iedereen met pension te sturen

- Overige punten:

- $\quad$ Pijnbeleving en stress is niet hetzelfde (maar wel beide belangrijk), dus deze vraag is te beperkt

\section{Selectiviteit}

- Bespreking van het begrip selectiviteit: moet gezien worden in het kader van het voorkomen van bijvangst en juist specifiek vangen van een bepaalde soort die je ook wil vangen.

- Methodes die bekend zijn voor duurzame methodes laten omarmen door vissers en maatschappij

- Problemen met duurzame methodes: innovatie moet meer gestimuleerd: vooral beleidsmatige problemen > dus er moet ruimte komen voor innovatie

- Momenteel veel vergunningen nodig en uiterst beperkte testgebieden

- Te kort aan financiële middelen

- $\quad$ Om selectiviteit in de visserij te bereiken en bevorderen heb je meer onderzoek nodig naar visgedrag:

- We moeten weten welke soorten wat doen om ze te kunnen vangen. Als je dit weet kun je nadenken over innovatie om op die manier de methodes te ontwerpen om toch te vangen wat je wil

- Het kaartje m.b.t. het voorspellen van locatie van visbestand valt grotendeels onder de kop onderzoek naar visgedrag

- Beter handhaven op illegaal gedrag is geen belangrijke vraag, maar wel een randvoorwaarden. Hetzelfde geldt voor werkbaar maken van de aanlandplicht

- Efficiënter maken van huidige vismethodes is concreet:

- Echter kan ook leiden tot meer bijvangst. Volgens andere deelnemers ligt dit aan je definiëring van efficiënt, het kan namelijk ook efficiënter zijn op het gebied van selectief vissen (daarbij juist minder bijvangst)

- $\quad$ Punt wordt ingebracht dat er wel degelijk kennis is over visgedrag, is niet per se een zwart wit discussie van totaal geen info tegen alle kennis hebben. Momenteel is de situatie dat er kennis is, maar dit kan altijd meer en beter. De vraag is echter of we op basis van de huidige kennis niet al sommige vragen kunnen beantwoorden.

- Conclusie:

- Top 3:

- 1: Onderzoek naar visgedrag

- 2: Ruimte voor innovatie creëren

- 3: Radicale herziening/innovatie van vistuigen

- Duurzaamheidsevaluatie van de vangstmethodes per vissoort komt als laatste

- Nog een laatste input vanuit deelnemer:

- Meer kennis ontwikkelen, maar ook focussen op implementatie en pilots, want juist hier kom je tot nieuwe inzichten

\section{Break-out sessie overig}

Heel kort behandeld door tijdsgebrek

- In bedden duurzaamheid en ecologie in het visserijonderwijs: er is momenteel weinig aandacht voor ecologie op visserijscholen en dit is nodig voor gedragsverandering

- Maar bovenaan komt inzicht kosten en baten van transities:

- Je moet weten hoe zit het in de praktijk en dit wil je vertalen naar het onderwijs

- Effecten van transities op voedsel web is fundamentele kennis en hoort daarom op plaats twee volgens een deelnemer

\section{Visserij: financieringsmogelijkheden}

\section{Groep 1}

Innovaties in bodemberoering, emissies en selectiviteit zouden moeten leiden tot een 'MSC+', waar de vissers belang bij hebben. De groep was het erover eens dat de pre-ontwikkelingskosten van innovatie 
door de overheid gedragen moeten worden, dat is niet ongebruikelijk. Het risico 'dat het niks wordt' kun je niet op de sector laten drukken. Wat je vaak ziet is dat investeringen niet gedaan worden omdat ze zich pas later terugbetalen. Voor veelbelovende technologie zouden licentierechten een optie kunnen zijn, waardoor investering zich terugverdient. Grote voordeel daarvan is openheid: een patent is voor de hele wereld beschikbaar, als je maar betaalt. Een andere optie is een investeringsfonds: je moet partijen vinden die willen investeren in iets wat in de toekomst geld opbrengt, zoals dat bij veel techbedrijven gaat. Er was in de groep discussie over of innovaties in 1 keer gerealiseerd moeten worden, of met kleine stapjes: slimmer vissen, andere locaties. Daarna ging de discussie over het delen van gegevens, en de voordelen daarvan. Kun je artificiële intelligentie inzetten voor de gemeenschap: voorspellen waar vis voorkomt, gerichter oogsten. Met zoiets is vorig jaar al begonnen (vis-hackaton). Je kunt beginnen met een individueel abonnement, die je kunt uitbreiden naar groepsabonnementen waarbij je meer informatie krijgt en een groter voordeel hebt. Of open source data. Bij mosselvissers is zoiets gedaan, waarbij bleek dat iedereen bij de buurman ging vissen. Je zou de verschillende opties door economen moeten laten uitwerken. Samengevat, het thema gaat over bodemberoering, en over emissies. Voor financiering stelt de groep drie mogelijkheden voor:

1. investeringsfonds

2. licenties/patent

3. data delen/abonnement (collectiviteit)

Daarna was er nog een kleine vervolgdiscussie over de technische aspecten van emissies. Scheepsbouwers zouden daarvoor een mogelijke investeerder kunnen zijn. Als we naar een 'zeroemission' schip willen, kan dat op waterstof en stroom? Is voor vissersschepen iets ingewikkelder dan voor vrachtschepen i.v.m. wisselende snelheid. Deze technische haken en ogen werden toelicht door MARIN.

\section{Groep 2}

De groep verdeeld de topprioriteit kennisvragen onder Publiek te financieren en mogelijk interessant voor Publiek private financiering:

Publiek:

- Inzicht inzet buitenlandse werknemers - onderdeel van Europese datacollectie verordening vanuit de sector is er wel belang voor deze vraag, maar is niet geschikt als een publiek private samenwerking.

- Inzicht in socio-economisch effecten van geplande ontwikkelingen op zee

- Inzicht in de gevolgen van de visserij transitie

Potentieel PPS

- Innovatie in de sector stimuleren

- Inpasbaarheid en medegebruik van de visserij

- Innovatie vistuig i.c.m. Optimaliseren verwerkingsproces

Optimaliseren van het verwerkingsproces kan meerdere doeleinden hebben vb. dierwelzijn, arbo, bijdragen aan het monitoren van visbestanden (bijv. camera detectie) want juist onderbouwt dat het voor zowel de sector als de maatschappij van belang is, waardoor het juist geschikt zou zijn voor een PPS (zowel privaat maar ook publiek).

Innovatie van het vistuig, het stimuleren van innovatie en inpasbaarheid in de toekomstige Noordzee is van belang voor visserijondernemers (automatisering kan leiden tot kostenbesparing, maar automatisering kan ook bijdragen aan verbeterde arbeidsomstandigheden (meer rusttijd). PPS is een mogelijkheid maar dan moet het een economisch voordeel brengen voor ondernemers.

Belemmeringen van PPS voor visserij die genoemd worden: In topsector call moet de visserijsector $50 \%$ bijleggen, dit is niet aantrekkelijk voor visserijondernemers. Daarnaast is het vele papierwerk/administratieve last dat bij (Europese) regelingen komt kijken vaak een belemmering voor vissers om er gebruik van te maken. 


\section{Groep 3}

Dierenwelzijn

- Publiek private financieringsopties voor:

- Systeemanalyse dierenwelzijn in het vangst en verwerkingsproces

- Wellicht deelname van dierenbeschermingsorganisaties, maar verwachting onder deelnemers is geen financiering, maar eerder beschikbaar stellen van manuren

- Vermindering letsel en mortaliteit

- Gedragsverandering vissers

- Bijv. publiekscampagne door NGO

- Overheid kan dit eventueel ook financieren

- Bedrijven willen best meefinancieren als ze er in hun bedrijfsvoering baat bij hebben bijv.: minder mensen nodig aan boord van een schip of verbeterde kwaliteit/houdbaarheid van de vangst

- Conclusie:

- Medefinanciering moet gekoppeld worden aan een commerciële verbetering en dus leiden tot meer inkomsten voor vissers anders geen mogelijkheden voor private gelden.

- Wellicht nog wel mogelijkheden door uitbreiden van bestaand label/certificaat zoals MSC met het thema dierenwelzijn. Verschillende deelnemers zien hier wel potentie in.

Selectiviteit

- Radicale herziening/innovatie van vistuigen

- Private samenwerking tussen bedrijf, visser en deels subsidie

- Ruimte voor innovatie creëren

- Voornamelijk politiek, maar ook financieel. Want eerste wat gebeurt is lagere inkomsten wanneer een visser een nieuwe techniek probeert. Dit wordt veroorzaakt door lagere visvangst wanneer een nieuw vistuig getest wordt. Deze terugval in inkomsten moet overbrugd worden.

- Europese component zit hier ook nog in dus niet alleen focussen op nationale budgetten

- Een van de deelnemers geeft nog aan dat er via de topsectoren al wel geld is gebruikt voor dit onderdeel.

- Onderzoek naar visgedrag

- WMR

- Visser zou het ook zelf kunnen onderzoeken, maar weinig fiducie dat ze mee willen werken.

- Deelnemer vraagt naar de mogelijkheden van het wellicht uitrusten van schepen met sensoren? Echter vissen boten alleen op specifieke plekken en focussen uitsluitend op volwassen vissen. Hierdoor kan je dus niks zeggen over paaigronden en dergelijken.

- Internationale partners: wellicht ICES

- Vissers vragen naar info over samenstelling van de vangsten en bijvangst zou ook bruikbare info kunnen opleveren. Echter zorgen over bereidheid van vissers om dit te delen i.v.m. concurrentiegevoeligheid.

- Conclusie:

- Vissers willen wel bijdragen. Argument van individuele vissers die technieken gaan testen is dat hele sector gaat profiteren, maar de individuele visser de lasten heeft. Hij kan de investering niet alleen betalen wanneer hij ook nog eens lagere vangsten heef. Oplossing is dat soms een hele visorganisatie mee financiert, want iedereen profiteert (collectieve financiering).

- Op Europees niveau wordt al gekeken naar financiering van testen en het tegemoetkomen van vissers door bijv.: huren van het schip voor een testperiode etc. 


\section{Biogrondstoffen: witte vlekken}

\section{Groep 1}

Doel om de witte vlekken per onderdeel van het innovatietraject van offshore zeewierkweek (prominent onderdeel van MMIP) in kaart te brengen.

De onderdelen teelt en veredeling zijn al redelijk goed in kaart gebracht (WUR grote bijdrage).

-IMTA en nutriënten: circulair maken van kweek, gebruikmaken van afvalstromen van verschillende trofische niveaus. Nutriënten circulair gebruiken is een belangrijk aspect. De nutriënten die we wegvangen met kweek, heeft namelijk ook effecten. Nutriënten die we wegvangen, heeft ook effect op aangrenzende landen. Daar zullen nutriënten worden afgenomen. Je neemt dit mee in de regelgeving. Hoe organiseer je dit? De EU kan wel richtlijnen geven.

Van de helft van de nutriënten kan je eigenlijk maar gebruik maken, de andere helft wordt hergebruikt door de Noordzee. Wat er van de overige helft ontrekbaar is, is afhankelijk van wat je maximaal zou willen. Als we uitgaan van $5 \%$ onttrekking uitgaan van de nutriënten, zouden we dat acceptabel vinden? Wat vinden wij acceptabel om te onttrekken? Daarover moet een beslissing genomen worden. Voorzichtig omgaan met die percentages.

-Medegebruik: gebieden die nu beschikbaar worden gesteld voor windparken, dat gaan we proberen slim te combineren met kweek. Parken die nu al gebouwd zijn of tot 2023 gepland zijn, zit medegebruik niet in de tender. Dus bij toekomstige parken zal dit erbij opgenomen moeten worden. Integrale aanpak. Daarin kunnen 'verplichtingen' opgenomen worden. In huidige parken liggen de kabels bijvoorbeeld niet goed.

-Multicropping is een belangrijk aspect voor dit thema. Bij één soort is er sneller kans op ziekten, etc. Welke soort wier je gaat kweken is afhankelijk van wat je wil. Saccharine heeft weinig eiwitten, veel suikers. Zeesla kun je niet goed offshore kweken.

-Gewasbescherming: biologische gewasbescherming voor teelt van gewassen (voorbeeld van tomatenplant, waarbij een zeewiersoort als biologische gewasbeschermer gebruikt wordt). Interessant voor biologische bestrijdingsmiddelen voor de markt? Wat is hier de potentiële markt voor?

-Andere landen: in Azië wordt veel zeewierteelt gedaan maar dat is vrijwel allemaal handmatig, geen offshore daar. We kunnen er misschien wel wat van leren. In België en andere Europese landen wordt ook aan zeewierkweek gedaan.

-Ook belangrijk om bedrijfsleven te betrekken. John van Leeuwen heeft hier kennis over. Er zit weinig/geen flow in om kennis te delen. Kleine bedrijven zijn vaak ook afhankelijk van subsidies. Samenwerking wordt nu soms belemmerd door financiering. Binnen de kweek zijn het vaak kleine bedrijfjes die geen geld in kunnen brengen om mee te doen aan een project. Er zit weinig cashflow. Er zijn veel bedrijven die nieuw zijn en die het nog niet heel erg in de vingers hebben, daarom lastig om financiering uit te krijgen. Voor financiering zou ook gedacht kunnen worden aan multifunctionele vissers. Vissersboot gebruiken voor de zeewierteelt. Vaste kosten heeft hij al gemaakt. Oogsten zou goedkoper kunnen worden als we hiervoor vissers aanspreken.

\section{Biogrondstoffen: financieringsmogelijkheden}

\section{Groep 1}

Wat leent zich voor publiek-private financiering? En welke partijen specifiek?

MMIP's richten zich op 2050. We moeten eerst de agenda hebben, dan moet je daar financiering voor vinden. Niet iets wat je 10 jaar vast moet houden en wat niet gewijzigd kan worden ook al blijkt het niet helemaal te werken.

PPS'en van de grond tillen is lastig. Het heeft dan wel wat met zeewier te maken maar misschien niet wat je precies zou willen. Je zit dan meer met wat het bedrijfsleven wil. Toeleveranciers zou je dan misschien kunnen proberen; offshore business. Maar de grote bedrijven willen eerst weten of er 
toekomst in zit. Het bedrijfsleven dat geïnteresseerd is, heeft eigenlijk geen geld. En de bedrijven die het wel zouden kunnen, zijn nog niet geïnteresseerd. Zij wachten op een beter businessmodel (ze willen zeker weten dat het geld oplevert en rendabel is). In eerste instantie om het van de grond te krijgen, zal het daarom door overheid gesubsidieerd moeten worden. Voor zeewier zou er ook een doelstelling moeten komen. Zeewier alleen als voedsel voor mensen zal het niet gaan halen. Er zullen ook andere doelen voor moeten zijn. Als het als doelstelling wordt opgenomen, dan zou het realiseerbaar zijn vanuit overheid. Bv. 10\% van biologische bestrijding moet uit zeewier komen/ CO2 reductie door vastleggen $\mathrm{CO}_{2} /$ eiwit transitie. Erg belangrijk dus: een duidelijke doelstelling opzetten. 
Waarom bedrijven zeewier geïnteresseerd zouden zijn in zeewier:

-Grondstof flexibiliteit

-Sourcing in toekomst zekerstellen

Er moet een noodzaak zijn om zeewierkweek te willen. Overheid heeft daarbij aan de voorkant een belangrijke rol. Als de mogelijkheden er zijn, dan zal de industrie later ook aansluiten. Er zullen dus randvoorwaarden gecreëerd moeten worden. En daar speelt de overheid een belangrijke rol.

Note: Bij NWO is er de $10 \%, 30 \%, 50 \%$ regeling van cofi, afhankelijk van type onderzoek. Hoe meer er zelf betaald wordt, hoe meer er besloten mag worden. Bij 10\% mag je alleen maar meekijken en niets beslissen. Binnen PPS 50/50.

\section{Bijlage B Kennisvragen Noordzee}

Wildcard:

Klimaatverandering: hoe snel gaat de zeespiegel stijgen richting 2100 ?

Klimaatverandering: wat zijn de effecten van grootschalige zandwinning t.b.v. kustverdediging in relatie tot zeespiegelstijging?

Klimaatverandering: wat zijn de effecten op het Noordzee ecosysteem en vispopulaties?

Medegebruik windparken op zee: wat zijn de kosten-baten van waterstofopslag?

Medegebruik windparken op zee: wat zijn de technische mogelijkheden en kosten-baten van voedselproductie (visserij en maricultures)

Medegebruik windparken op zee: wat zijn de technische mogelijkheden van zandwinning in windparken t.b.v. zandbehoefte voor kustverdediging in de toekomst?

Basiskennis ecosysteem: welke aanpassingen zijn nodig zodat de huidige monitoringsprogramma's de vragen van de toekomst (o.a. draagkracht van het systeem) kunnen beantwoorden?

Basiskennis ecosysteem: hoe en waar kunnen geschikte referentiegebieden worden ingericht?

Natuurversterking: aan welke kwaliteitseisen moet nieuwe natuur voldoen?

Natuurversterking: kosten-baten analyse natuurversterkende maatregelen/natuur inclusief bouwen.

Waardering ecosysteem: kunnen natuurlijk kapitaalrekeningen een rol spelen bij monetarisering van ecosysteemdiensten en -goederen?

Verkeersbeeld: hoe ziet het verkeersbeeld in de Noordzee er in de toekomst uit?

Grootschalige bouwwerken op zee (windparken, (energie)eilanden): hoe brengen we de basiskennis van het fysisch, chemisch en ecosysteem op orde om effecten van ingrepen/bouwwerken te kunnen beoordelen en afwegingen te kunnen maken?

Grootschalige bouwwerken op zee (windparken, (energie)eilanden): hoe kan de infrastructuur op een efficiënte manier worden aangelegd en samen worden gebruikt?

Grootschalige bouwwerken op zee (windparken, (energie)eilanden): hoe ziet de arbeidsmarkt van de toekomst er uit?

Wind op zee: is er voldoende wind om de huidige ambitie van Nederland en die van andere Noordzeelanden te kunnen realiseren (o.a. zog-effect = letterlijk elkaars wind afvangen)? 
Wind op zee: welke compenserende maatregelen kun je nemen bij het optreden van negatieve effecten op de natuur?

\section{Bijlage C Kennisvragen Visserij}

\section{Dierwelzijn}

Kennis: waterrijk verwerkingsproces vis aan boord (technisch haalbaar, effectief)

Kennis: versnellen verwerkingsproces vis aan boord (automatisering, verandering

bemanningsprocessen, analyse verwerkingsketen)

Beheer: dierwelzijnscertificaat (is er een markt? Welke instantie?)

Kennis: onderzoek pijnbeleving bij vissen (en doorwerking van deze kennis in visserij)

Kennis: diervriendelijkste verdovingstechniek

Tech: vermindering letsel en mortaliteit bijvangst (bodemdieren, vis, vogels en zeezoogdieren)

Kennis: systeemanalyse dierwelzijn in het vangst- en verwerkingsproces (verbetering in het proces)

Kennis: gedragsverandering vissers

Wildcard

\section{Emissies}

Tech: efficiënter in plannen van visroutes (software)

Tech: innovatie vistuigen dat weerstand verminderd

Tech: innovatieve voortstuwingssystemen en bijbehorende infrastructuur (elektrisch, etc.)

Systeeminnovatie: totale vernieuwing van de visserijvloot (minder maar grotere schepen met meer capaciteit)

Systeeminnovatie: totale vernieuwing van de visserijvloot (meer kleinere passieve visserijschepen met minder capaciteit)

Beheer: Efficiëntie criterium voor schepen / Emissie quota voor schepen

Beheer: Weekendstop / Reductie aantal visdagen

Kennis: voorspelbaarheid (real time) locatie visbestanden voor efficiënter gebruik brandstof

Wildcard

\section{Selectiviteit}

Kennis: voorspelbaarheid locatie commerciële en niet-commerciële visbestanden om selectief te vissen en bijvangst te verminderen (real time)

Kennis: duurzaamheidsevaluatie van de vangstmethodes per vissoort

Kennis: hoe kunnen efficiënte en duurzame methodes omarmd door visser en maatschappij

Kennis: gebruik ecosysteembenadering bij de totstandkoming van quota/TACs (wat brengt ecosysteem op, rekening houdend met leeftijdsevenwicht in bestanden, doorwerking in het voedselweb, enz.)

Innovatie: radicale herziening/innovatie van vistuigen (selectief adv detectie en of sortering onderwater met camera's en sensoren, incl. de nodige governance)

Innovatie: efficiënter maken van huidige vismethodes

Beheer: ruimte voor innovatie creëren (in regelgeving/financieel)

Beheer: beter handhaven op illegaal gedrag aan boord van legale vissersschepen

Kennis: onderzoek naar visgedrag (in relatie tot het vistuig/migratie)

Beheer: werkbaar maken van de aanlandplicht

Kennis: Innovatie stimuleren in de sector

Wildcard

\section{Bodemberoering}

Beheer: inzet van efficiëntie criteria (eenheid bodemberoering per $\mathrm{kg}$ vis of $\mathrm{kg}$ eiwit) voor vis licentie (controle \& handhaving)

Beheer: inzet credit systeem gebruikt worden voor ontzien gevoelige habitat types? (hoe gevoeliger de habitat, hoe meer 'strafpunten') - (keus, gedrag)

Kennis: gebiedstoewijzing op basis van hoge veerkracht van gebieden (al onderhevig aan hoge bodemdynamiek)

Vloottransitie: haalbaarheid transitie actieve visserij (sleepnetten) naar passief (kooien, staand want, etc.) 
Bodemberoering - Vloottransitie: haalbaarheid transitie visserij naar kleiner \& lichter (kleinere schepen, lichtere netten)

Kennis: combineren van gesloten gebieden en windparken t.b.v. natuurwinst

Beheer: periodiek gesloten i.p.v. permanent gesloten gebieden (hoe lang is de hersteltijd bodem)

Kennis: inzicht in effect bodemberoering van verschillende ingrepen op de

Noordzee (visserij, najaarsstorm, zandwinning, windparken, mijnbouw, pijpen/kabels in graven etc.)

Kennis: zijn er naarEU-maatstaven (KRM, Natura 2000, OSPAR) voldoende voor

bodemberoering gesloten gebieden of ontbreken er nog gebieden?

Tech: Inzetten op alternatieve en/of innovatieve vistuigen met minder bodemberoering incl. De

nodige governance/betrekken van stakeholder (alternatief voor de puls).

Kennis: wat zijn de effecten van nieuwe vistuigen op het mariene ecosysteem?

(vispopulaties, bodemleven, doorwerking naar voedselweb)

Wildcard

\section{Goede boterham}

Kennis: Innovatie in de sector stimuleren (levensvatbaarheid van verduurzaamde Noordzee zonder subsidie)

Kennis: Inzicht socio-economische effecten van geplande ontwikkelingen op zee en de impact op de visserij (impact cumulatieve drukfactoren: beschikbaar quota, klimaatverandering, WOZ, Brexit, Puls, gebiedssluiting, aanlandplicht, contractvissen).

Kennis: Inzicht ecologische effecten van geplande ontwikkelingen op zee en de impact op de visserij (impact cumulatieve drukfactoren: beschikbaar quota, klimaatverandering, WOZ, Brexit, Puls, gebiedssluiting, aanlandplicht, contractvissen).

Kennis: Inzicht in kostenbesparing mogelijkheden voor visserij (vislocaties, vismethoden, zuinigere voorstuwingstuigen)

Kennis: Afwegingen ecologische duurzaamheid en economische belang van kleinschalige visserij

Tech: Inpasbaarheid en medegebruik van de visserij in geplande ontwikkelingen op zee

(WOZ/Energie-eilanden, aquacultuur, onderhoud van OWFs)

Markt: Mogelijkheden om de innovatiekosten door te berekenen naar de consument door een hogere prijs voor duurzamere vis (certificering, marketing, valorisatie bijvangsten)

Systeeminnovatie: Optimalisatie van de organisatie van de visserij sector op NL niveau (PO, visafslag, restauratieplan)

Systeeminnovatie: Socio-economische en ecologische uitkomsten van consolidatie in de vloot naar grote rederijen in plaats van familiebedrijven (bedrijfsvoering)

Systeemtransitie: Hoe kan de opleiding/omscholing van vissers bijdragen aan de inpasbaarheid van de visserij op de Noordzee

Tech: Inzetten op een high tech visserij (gebruik van nieuwste technische ontwikkelingen Wildcard

\section{Arbo}

Kennis: Inzicht in de effecten van de visserijtransitie (wat zijn effecten op arbeidsmarkt, welke vaardigheden hebben toekomstige vissers nodig)

Kennis: Gedragsverandering t.b.v. veiligheid: hoe te bereiken (handhaving aan boord, onderwijs, cultuuromslag)

Kennis: Inzicht inzet buitenlandse werknemers (gelijke betaling/veiligheidseisen/gevolgen NL werknemers)

Tech: Innovatie \& optimalisatie veiligheidsmateriaal (draagbaarheid reddingsvesten, helmen, man over boord \& GPS, etc.)

Tech: Innovatie vistuig (minder gevaarlijke handelingen, automatisering sortering, langere rustperiodes)

Tech: Optimaliseren van het visverwerkingsproces (automatische sortering, camera detectie)

Tech: Ontwikkelen van Werkeilanden, Moederschepen of aanpassen windparken (t.b.v. overnachting, verwerking).

Beheer: Internationale afspraken (erkenning van diploma's van bemanning tussen landen; inzet internationale bemanning aan wal - werkvergunning)

Arbo - Beheer: Alternatief model betalingssysteem bemanningsleden (financiële zekerheid, minder prikkels tot gevaarlijk gedrag) 


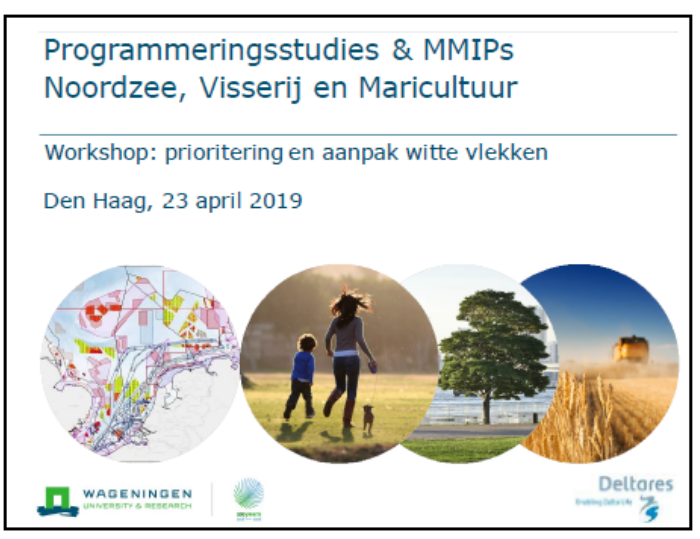

Context: KIA Landbouw, Water \& Voedsel

- Topsectoren 2.0

- Missiegedreven innovatiebeleid

- Missies opstellen door departementen

- Kennis- \& Innovatieagenda (KIA) door topsectoren A\&F, T\&U en water

- Daarnaast klimaatakkoord (incl. Noordzee OFL-traject)

- Programmeringsstudies door Wageningen Research

- Input voor KIA-Landbouw Voedsel Water

- Koppeling aan Meerjarig Missiegedreven Innovatie Programma (MMIP)

D. WAGENINGEN Deltares
Aanpak programmeringsstudies

- Samenwerking tussen de 3 programmeringsstudies Noordzee, Visserij en (blauwe deel) Biogrondstoffen

- Analyse: wat weten we wel, niet of gedeeltelijk?

- Kennisagenda Noordzee2030

- Interviews \& online enquête (focus visserij, extra vraag Noordzee)

- Klimaatakkoord

- Overzicht beschikbare financieringsinstrumenten

- Workshop 23 april: prioritering en aanpak witte vlekken

- COP 14 mei: consultatie \& match-making stakeholders

1. WAGENINGen
Tussentijdse resultaten:

financieringsmogelijkheden

- Ruim 30 verschillende mogelijkheden

- Publiek, charitatief, publiek-privaat

- Verscheidenheid aan subsidiabele kosten

- Toegankelijkheid voor kennisinstellingen verschilt

- Veel financiering vooral vanuit LNV gedreven

- Weinig integrale aanpak

D. WAGENINGEN

LWV: 6 missies
- A: Kringlooplandbouw
"B: Klimaatneutrale landbouw en voedselproductie
- C: Klimaatbestending landelijk en stedelijk gebied
- D: Gewaardeerd, gezond en veilig voedsel
"E: Duurzame en veilige Noordzee, oceanen en
binnenwateren
- F: NL best beschermde en leefbare delta ter wereld
D. WAaENINGEN

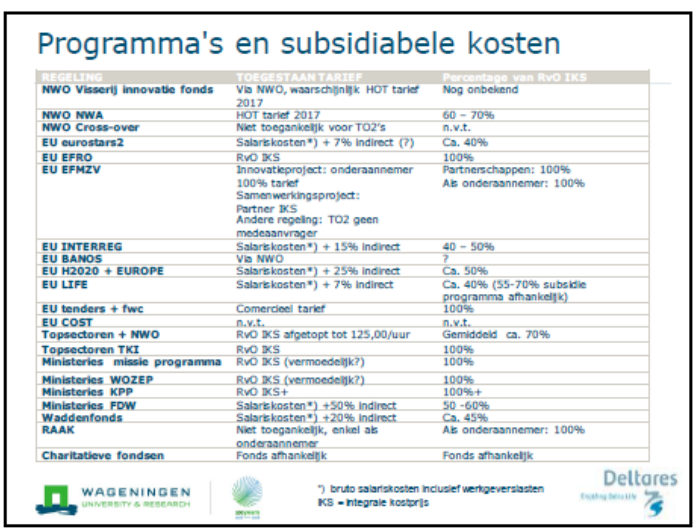


Tussentijdse resultaten (Noordzee, Visserij en blauwe deel Biogrondstoffen)

- >230 kennis- en innovatievragen

- Deels gericht op 'techniek en infrastructuur'

- Volledig witte vlekken: 148

- NWA-voorstel North Sea in Transition pakt 68 witte vlekken aan (kanttekening: reken jezelf niet rijk)

D. WAGENINGEN

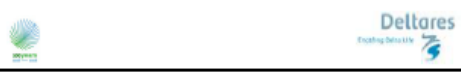

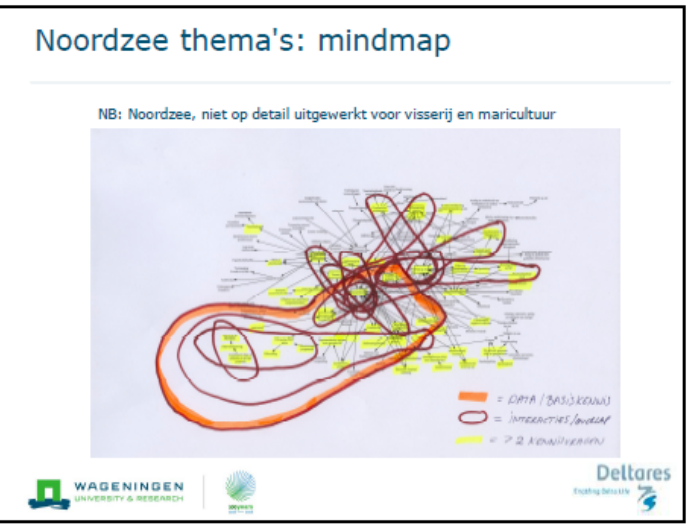

Noordzee thema's: witte vlekken (alfabetisch, excl. visserij en maricultuur)

- Basiskennis ecosysteem

- Grootschalig bouwen

- Klimaatverandering:

- Medegebruik

- Natuurversterking

- Verkeersbeeld

- Waardering ecosysteem

- Wind op zee

D. WAGENINGEN
Visserij thema's: witte vlekken

Interviews (10) \& online survey (83)

Focus: minder emissies, dierwelzijn, goede

arbeidsomstandigheden,

minder bodemberoering,

selectiviteit, goede

boterham.

Resultaat: +/- 120 witte vlekken

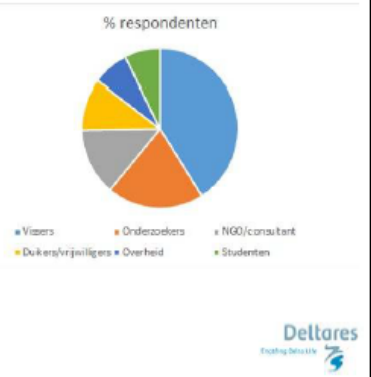

D. WAGENINGEN
Prioritering op basis van de survey

21. Als u een subsidie van $\mathfrak{\epsilon} 2$ miljoen euro zou krijgen om aan de slag te gaan voor een duurzame visserij op d...en zou u dan als eerste aanpakken?

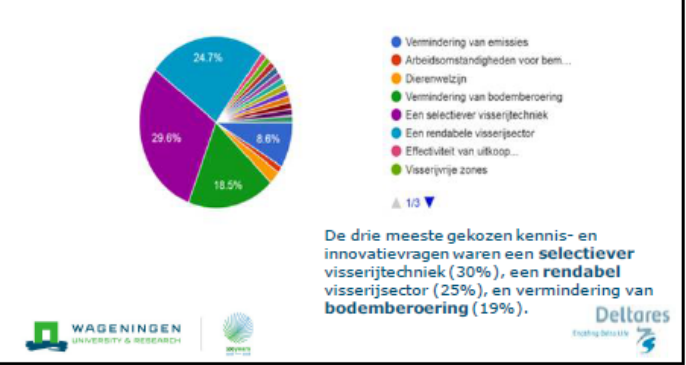

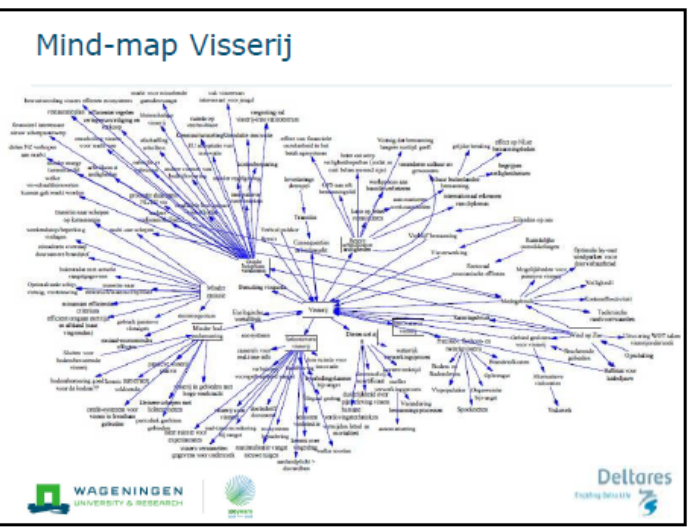




\section{Visserij thema's: witte vlekken}

- Basiskennis: visgedrag, verspreiding commerciële en nietcommerciële visbestanden, ecosysteembenadering.

- Innoveren: vistechnieken, netinnovaties, high tech/real-time monitoring, voortstuwingssystemen, verwerkingsproces, werkeilanden, materiaal, ruimte.

- Gedrag: stimuleren van innovatie, overstap duurzame brandstof, veiligheid, dierwelzijn.

- Effecten: transities, mogelijke maatregelen, handhaving, labels, nieuwe vistuigen op ecosysteem.

- Markt: nieuwe verdienmodellen, toekomstige vaardigheden, kostenverlaging/opbrengstverhoging.

D. WAGENINGEN

\section{e}

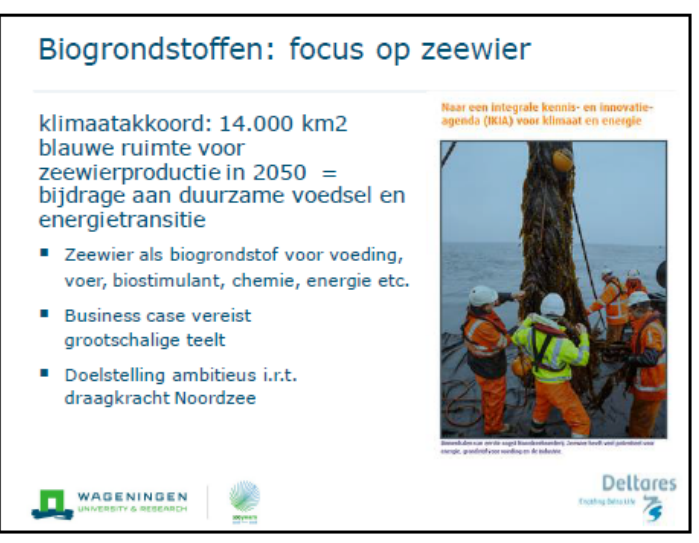

Grootschalige aanpak, grote vraagstukken

- Zeewier als bulkgrondstof: grootschalige productie

- Grootschalige, gemechaniseerde teeltsystemen (geschikte locaties?, geschikte hardware?)

- Verwerking : integreren met andere activiteiten op NZ

- Productie : diepere kennis over genetica, fysiologie, morfologie Genetische diversiteit (biobank/genenbank)

- Afzet/markt : ontwikkeling business cases

- Ketenaanpak: slimme combi's

- Risico's: monitoringsprogramma's ecosysteemeffecten

- Wet-en regelgeving, aansprakelijkheid

Innovatietraject (MMIP is eerste aanzet)

Ontwikkeling Ketenaanpak

- Opzetten fundamentele onderzoeksprogramma's (NWO, TO2financiering, TKI-middelen)

- Implementatietrajecten / demo-programma's (ism telers, andere partijen op Noordzee, monitoring door KI's)

Samenwerking:

- Overheden (I\&W, LNV, EZK, BZK,...)

- Bedriifsleven en Topsectoren (TKI-WoZ, TKI-A\&F, ...) $^{2}$

- Kennisinstellingen (TO2-instellingen, universiteiten,....)

- .....

D. WAGENINGEN

\section{Werksessie: 2 opdrachten}

1. Pressure cooker: prioritering witte vlekken?

2. Brainstorm: hoe gaan we deze aanpakken?

1. WAGENINGEN
Opdracht 1: pressure cooker prioritering

- Maximaal 25 minuten

- Wijs iemand aan die plenaire terugkoppeling doet

- Leg samen de kaartjes op volgorde van prioriteit (nummer ze als je klaar bent)

- 1 'wildcard' voor maximaal 1 eigen kennis- of innovatievraag (mag, hoeft niet)

- Plenaire terugkoppeling (3 minuten!):

- Presenteer jullie top 3 prioriteiten

- Wildcard ingezet?

- Over welke volgorde had jullie de meeste discussie? 


\section{Opdracht 2: aanpak prioriteiten}

- Zelfde groepen

- Wijs iemand aan die plenaire terugkoppeling doet

- Noordzee: Geef voor minimaal jullie top 3 prioriteiten jullie financiële advies

- Visserij en maricultuur: Welke vragen lenen zich voor publiek-private financiering? En welke partijen zijn dit dan?

- Plenaire terugkoppeling (3 minuten!)

- Presenteer het advies voor jullie top 3 prioriteiten

- Waarover hadden jullie de meeste discussie?

WAGENINGEN

Deltares

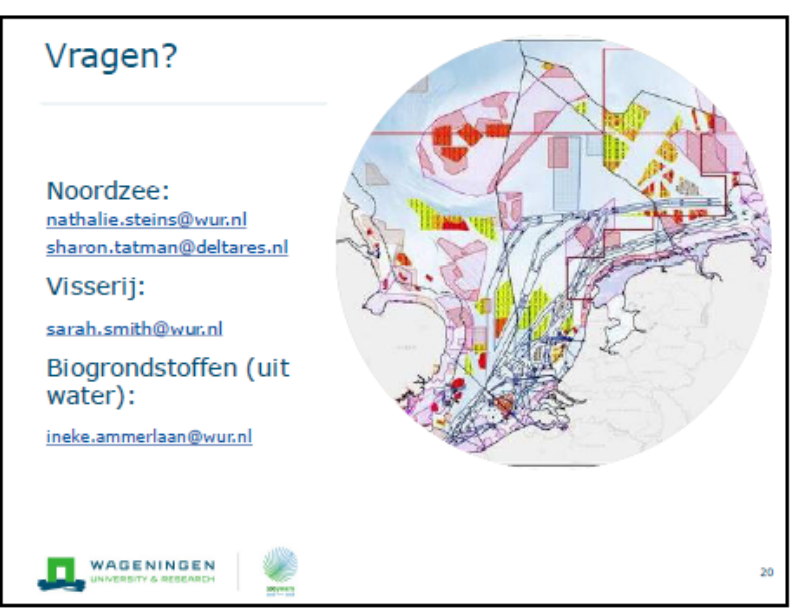




\title{
Bijlage 4 Verslag stakeholder workshop 14 mei 2019
}

\begin{abstract}
Aanleiding
Nederland staat voor een aantal grote maatschappelijke uitdagingen op het terrein van voedselproductie, gebruik van grondstoffen, klimaatverandering, waterkwaliteit en duurzaam gebruik en beheer van grote wateren. Binnen het thema Landbouw, Water, Voedsel heeft het Ministerie van Landbouw, Natuur en Voedselkwaliteit (LNV) zes missies gedefinieerd om deze maatschappelijke opgaven aan te pakken en ook kansen kunnen bieden voor het versterken van de concurrentiekracht van het Nederlandse bedrijfsleven. De missies vormen ambities voor kennis en innovatie; zij moeten prikkelen tot ambitieus onderzoek en de toepassing ervan in de praktijk. De missies voor Landbouw, Water, Voedsel zijn opgesteld in het kader van het missiegedreven topsectorenbeleid en uitgangspunt voor de topsectoren Agri \& Food, Tuinbouw \& Uitgangsmaterialen, en Water.
\end{abstract}

Het ministerie van LNV en de topsectoren Agri \& Food, Tuinbouw \& Uitgangsmaterialen en Water werken op dit moment aan een gezamenlijke Kennis \& Innovatie Agenda (2020-2024) om te komen tot een samenhangende integrale aanpak die zowel bijdraagt aan het oplossen van maatschappelijke uitdagingen als ook aan het verdienvermogen. Vooruitlopend op de uitwerking van de nieuwe Kennisen Innovatie Agenda loopt er nu al de call van 2019 van de topsectoren Agri \& Food en Tuinbouw \& Uitgangsmaterialen.

De complexiteit van de opgaven vraagt om een gezamenlijke aanpak. Het uitgangspunt voor de gezamenlijke aanpak vormt publiek-private samenwerking bij het vinden en implementeren van oplossingen. Daar waar publiek-private samenwerking alleen niet de oplossing kan vormen om de missiedoelen te bereiken, kan een puur publieke inzet helpen.

Het ministerie van LNV en de topsectoren Agri \& Food en Tuinbouw \& Uitgangsmaterialen hebben Wageningen Research gevraagd om zogenaamde programmeringsstudies uit te voeren en, daaraan gekoppeld, input te leveren voor de Meerjarige Maatschappelijke Innovatie Programma's. Doel van de programmeringsstudies is om een goed beeld te krijgen van de kennis- en innovatievragen voor de verschillende missies, te inventariseren welk onderzoek er al loopt, waar nog lacunes (witte vlekken) zitten, en hoe deze witte vlekken via PPS (topsectoren) of andere programma's kunnen worden opgepakt. Ook de blauwe ruimte is onderdeel van deze programmeringsstudies. Wageningen Research werkt binnen dit thema aan drie aan elkaar gerelateerde programmeringsstudies: (1) Noordzee (i.s.m. Deltares), (2) Visserij en (3) Biogrondstoffen (waaronder biogrondstoffen uit de blauwe ruimte, bijv. via maricultuur).

\section{Aanpak en tussentijdse resultaten}

Op 23 april 2019 is er een eerste werksessie gehouden. Deze was op verzoek van de opdrachtgever gericht op deelnemers uit het beleid (betrokken ministeries bij Noordzee 2030) en onderzoek. De stakeholder workshop op 14 mei 2019, waar dit verslag betrekking op heeft, had twee doelen: (1) het krijgen van input op de tussentijdse resultaten en in het bijzonder de concepten van de Meerjarige Missiegedreven Innovatieprogramma's (MMIPs) voor Noordzee, Visserij en Biogrondstoffen uit de Blauwe Ruimte, en (2) het uitwerken van een aantal kennis- en innovatiecasussen als input voor de programmeringsstudies. De stakeholderworkshop werd gekoppeld aan een bijeenkomst van de Community of Practice Multi-use Noordzee (COP), een initiatief van het Ministerie van LNV en de Rijksdienst voor Ondernemend Nederland (RVO). De COP-bijeenkomst werd door ongeveer 80 deelnemers uit belangenorganisaties (o.a. energie, visserij), maatschappelijke organisaties, overheid, consultants en onderzoek, bezocht.

De tussentijdse resultaten van de programmeringsstudies Noordzee, Visserij en Biogrondstoffen werden gepresenteerd, zie de PowerPointpresentatie van de werksessie (14 mei 2019) in Bijlage I. 
De input van de stakeholders werd gezocht via 3 opdrachten:

1. burengesprek;

2. stickeren van prioriteiten op de concept-MMIPs;

3. werksessies rond innovatiecasussen.

Deze worden hieronder opeenvolgend verder uitgewerkt.

\section{Burengesprek}

Tijdens de presentatie in het plenaire gedeelte kregen de deelnemers de opdracht om in de vorm van een burengesprek in 5 minuten de volgende vraag te beantwoorden:

"Als jullie een subsidie van $2 \mathrm{mln}$ euro zouden krijgen voor het beantwoorden van één kennisvraag of voor het uitvoeren van één innovatieproject op de Noordzee, waar zouden jullie dat geld dan aan uitgeven?"

De antwoorden werden op een kaartje geschreven en ingeleverd. De resultaten staan in onderstaande tabel.

\begin{tabular}{|c|c|c|}
\hline Antwoord & MMIP thema & Type vraag \\
\hline $\begin{array}{l}\text {-Economische haalbaarheid medegebruik } \\
\text {-Praktisch voorbeeld: pilot project voor economisch } \\
\text { én ecologische haalbaarheid medegebruik = } \\
\text { verdienmodel natuurontwikkeling in rendabel model. }\end{array}$ & Combinatie & Innovatievraag \\
\hline $\begin{array}{l}\text { Ontwikkelen oester hatchery voor herstelprojecten, } \\
\text { anders geen oesters. Geldt ook voor zeewier. }\end{array}$ & Combinatie & Innovatievraag \\
\hline $\begin{array}{l}\text { Ruimtelijke inpassing van alle activiteiten samen. } \\
\text { Waar ga je wat doen? }\end{array}$ & Combinatie & Kennisvraag \\
\hline $\begin{array}{l}\text { Samenwerking met Greenport om zeewierteelt + } \\
\text { rendement te optimaliseren (kennis + expertise). }\end{array}$ & Zeewier & Combinatie \\
\hline $\begin{array}{l}\text { Hergebruik olie en gas infrastructuur voor } \\
\text { energieopslag. }\end{array}$ & Noordzee & Innovatievraag \\
\hline $\begin{array}{l}\text { Technische en economische haalbaarheid van } \\
\text { projecten. Inzicht in potentieel, timing en of } \\
\text { opschalen realistisch is voor nieuwe energie en } \\
\text { voedsel technieken (bijv. kweektechnieken, } \\
\text { energievliegers, golfenergie) }\end{array}$ & Noordzee & Innovatievraag \\
\hline $\begin{array}{l}\text { Integrale gebiedsontwikkeling windpark op zee } \\
\text { (bijv. Hollands Kust Zuid/West). Dus direct samen } \\
\text { met wind, zeewier, vis, natuur. }\end{array}$ & Noordzee & Innovatievraag \\
\hline $\begin{array}{l}\text { Praktijkcasussen: } \\
\text {-Kan zeewier } \\
\text {-Kan golfslaggenerator }\end{array}$ & Combinatie & Kennisvraag \\
\hline
\end{tabular}




\begin{tabular}{|c|c|c|}
\hline Antwoord & MMIP thema & Type vraag \\
\hline $\begin{array}{l}\text { Samenwerking tussen de topsectoren om tot een } \\
\text { MMIP medegebruik binnen en buiten de windparken } \\
\text { te schrijven + realiseren. }\end{array}$ & Noordzee & Combinatie \\
\hline $\begin{array}{l}1 \text { soort zeewier op } 5 \text { locaties met } 5 \text { verschillende } \\
\text { kweeksystemen. }\end{array}$ & Zeewier & Innovatievraag \\
\hline Leren door te doen op pilotbasis. & Combinatie & Innovatievraag \\
\hline Kans op schade is groter zonder juiste kennis. & Combinatie & Kennisvraag \\
\hline $\begin{array}{l}\text { Wat zijn de cumulatieve effecten van alles wat we } \\
\text { doen en extra gaan doen op zee? }\end{array}$ & Combinatie & Kennisvraag \\
\hline $\begin{array}{l}\text { Hydrodynamische modellering van grote flexibele } \\
\text { constructies op zee en hun interacties. }\end{array}$ & Combinatie & Kennisvraag \\
\hline $\begin{array}{l}\text { Ontwikkelen middenschaalpilot zeewier in windpark } \\
\text { m.n. verankering en scour protection als ecologisch } \\
\text { 3D Netwerk. }\end{array}$ & Zeewier & Innovatievraag \\
\hline $\begin{array}{l}\text { Productierif: tussen de palen van een OWF } \\
\text { rifstructuren aanleggen die biodiversiteit en } \\
\text { biomassa stimuleren + krabben en kreeften } \\
\text { stimuleren (en andere commerciële soorten). }\end{array}$ & Noordzee & Innovatievraag \\
\hline $\begin{array}{l}\text { In praktijk uitvoering. Dit scherpt nader aan welke } \\
\text { kennis/ervaring mist. }\end{array}$ & Combinatie & Innovatievraag \\
\hline $\begin{array}{l}\text { Businesscase: platte oesterkweek op de Noordzee. } \\
\text { Wat kan er en wat is rendabel? }\end{array}$ & Noordzee & Combinatie \\
\hline pilot met zeewier: 5 hectare met 6 soorten. & Zeewier & Innovatievraag \\
\hline $\begin{array}{l}\text { Onderzoek naar mogelijkheden voor oesterkweken } \\
\text { (broedjes) in vijvers vóór uitzetten in de } \\
\text { windmolenparken. }\end{array}$ & Noordzee & Innovatievraag \\
\hline $\begin{array}{l}\text { Onderzoek naar haalbaarheid informatiesysteem + } \\
\text { verspreiding van (Noordzee)kennis. }\end{array}$ & Noordzee & Innovatievraag \\
\hline $\begin{array}{l}\text { Onderzoek naar cumulatieve effecten van } \\
\text { medegebruik in windparken op zee. }\end{array}$ & Noordzee & Kennisvraag \\
\hline $\begin{array}{l}\text { In hoeverre is doorvaart/medegebruik } \\
\text { verzekerbaar? }\end{array}$ & Noordzee & Kennisvraag \\
\hline $\begin{array}{l}\text { Wat is de invloed van windparken op } \\
\text { bodemgesteldheid/ecologie? }\end{array}$ & Noordzee & Kennisvraag \\
\hline $\begin{array}{l}\text { Ondernemersperspectief voor vissers ontwikkelen } \\
\text { (diversificatie). }\end{array}$ & Visserij & Innovatievraag \\
\hline $\begin{array}{l}\text { Bijdragen aan haalbaarheidsstudie voor Floating } \\
\text { Airport d.m.v. onderzoeksstation met snelle } \\
\text { dataverbinding. }\end{array}$ & Noordzee & Innovatievraag \\
\hline
\end{tabular}




\begin{tabular}{|l|l|l|}
\hline Antwoord & MMIP thema & Type vraag \\
\hline $\begin{array}{l}\text { Zet in voor het vervolg op pilotstudies voor passieve } \\
\text { visserij. Dus selecteer één van die projecten en } \\
\text { maak de vervolgstap mogelijk. }\end{array}$ & Visserij & Innovatievraag \\
\hline $\begin{array}{l}\text { Reeds beschikbaar, het volledig circulair kweken van } \\
\text { soorten vis- en schaaldieren om de natuurlijke } \\
\text { populatie te versterken. }\end{array}$ & Noordzee & Innovatievraag \\
\hline $\begin{array}{l}\text { De integratie van aquacultuur met visserij, } \\
\text { voedselvoorziening en verrijken van de biodiversiteit } \\
\text { (ecologisch herstel). Onder het motto: "Een vis op } \\
\text { je bord, een vis in zee". }\end{array}$ & Visserij & Innovatievraag \\
\hline $\begin{array}{l}\text { Drijvende luchthaven c.q. H2 productie ook voor } \\
\text { kustvaart: } \\
\text {-Zeewierverwerking } \\
\text {-Vissershaven }\end{array}$ & Noordzee \\
\hline $\begin{array}{l}\text { MMIP publiceren over 'Samenwerken natuur + } \\
\text { voedselvoorziening'. Samenwerking is } \\
\text { tweerichtingsverkeer. }\end{array}$ & Noordzee & Innovatievraag \\
\hline
\end{tabular}

\section{Prioritaire onderwerpen concept-MMIPs}

Gedurende de dag mochten alle deelnemers maximaal 3 stickers plakken op de onderwerpen in de concept MMIPs die volgens hen prioriteit hadden. Dit leverde de onderstaande resultaten op.

\section{Prioritering stakeholders concept-MMIP Duurzame Noordzee}

(loopt door naar volgende pagina)

MMIP - MISSIE DUURZAME NOORDZEE (NB: Noordzee-onderdelen Visserij en Maricultures in aparte MMIPs uitgewerkt)

\begin{tabular}{|c|c|c|c|c|}
\hline Deelprogramma & Onderzoeksfase & Ontwikkelfase & Demonstratiefase & Implementatiefase \\
\hline \multicolumn{5}{|c|}{ Monitoring, modellering, data- en informatiemanagement en afwegingskaders voor menselijk medegebruik binnen de draagkracht van het Noordzee ecosysteem } \\
\hline $\begin{array}{l}\text { Robuuste } \\
\text { basiskennis rysisch, } \\
\text { chemisch en } \\
\text { ecologisch systeem } \\
\text { Noordzee. }\end{array}$ & 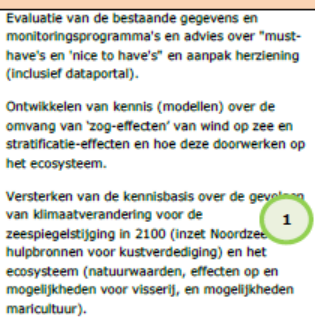 & $\begin{array}{l}\text { Ontwikkeling van een integraal monitoring-programma } \\
\text { en data portal. }\end{array}$ & $\begin{array}{l}\text { Uitvoeren van een aantal proeven waarblis } \\
\text { verzameling van gegevens ult verschillende } \\
\text { programma's binnen eén monitoringsactiviteit } \\
\text { wordt uitgeveerd. }\end{array}$ & $\begin{array}{l}\text { Hoe organiseren we een integrale inrichting en } \\
\text { coorddinatie van lopende en nieuwe } \\
\text { monitioringsprogramma's vanult de verschillende } \\
\text { betrokken ministeries en kennisinstellingen? } \\
\text { Hoe en waar kunnen geschilkte referentiegebieden } \\
\text { worden ingericht? }\end{array}$ \\
\hline $\begin{array}{l}\text { Monitorings- en } \\
\text { data science } \\
\text { technieken van de } \\
\text { toekomst. }\end{array}$ & $\begin{array}{l}\text { Ontwikkelen van fundamentele en toegepaste } \\
\text { kennis over inzet van innovartie (remote) } \\
\text { monitoringstechnieken en hun praktische } \\
\text { toepasbaarheid in de condities op en in de } \\
\text { Noordzee (bilv. DNA-technieken, akoestiek, } \\
\text { cameratechnieken, drones). }\end{array}$ & $\begin{array}{l}\text { Ontwikkelen van nieuwe monitoringstechnieken voor } \\
\text { verzamelen van basisgegevens over rysisch, chemisch } \\
\text { en ecologisch ecosysteem. } \\
\text { Ontwikkelen van nieuwe data-opslag, -verspreiding } \\
\text { technieken (data science) voloens Europese kennis- en } \\
\text { datatstandarden (bijv. EMODNET). } \\
\text { Ontwikkelen van nieuwe technieken voor } \\
\text { effectmetingen van menselijke ingrepen. }\end{array}$ & $\begin{array}{l}\text { Praktijkk klaar maken van nieuwe monitorings- en } \\
\text { data science technieken. }\end{array}$ & $\begin{array}{l}\text { Hoe brengen we succesvolle nieuwe } \\
\text { monitoringtechnieken binnen bestaande } \\
\text { monitoringsprogramma's (ffnanciering, } \\
\text { ondertreksing langjarige (jjdsreeksen)? }\end{array}$ \\
\hline $\begin{array}{l}\text { Afwegingskaders } \\
\text { duurzaam gebruik } \\
\text { Noordzee. }\end{array}$ & 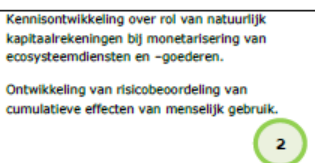 & $\begin{array}{l}\text { Ontwikkelen van een integraal afwegingskader } \\
\text { inpassing van menselijke ingrepen en activiteiten } \\
\text { binnen de grenzen van de draagkracht van het } \\
\text { Noordzze ecosysteem. }\end{array}$ & & 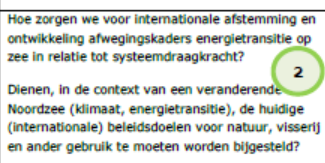 \\
\hline \multicolumn{5}{|c|}{ Natuurvriendelijke aanleg van grootschalige bouwwerken voor energieproductie en stimulering van natuur hierbinnen } \\
\hline $\begin{array}{l}\text { Natururinclusief } \\
\text { bouwen. }\end{array}$ & 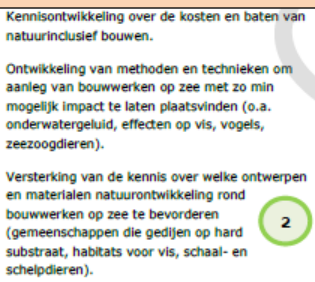 & 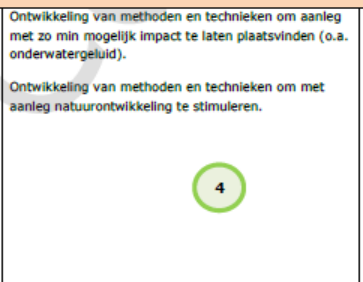 & Uitvoeren van pilots. & 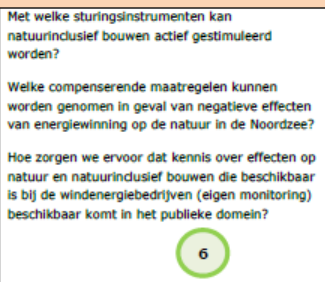 \\
\hline
\end{tabular}


(vervolg)

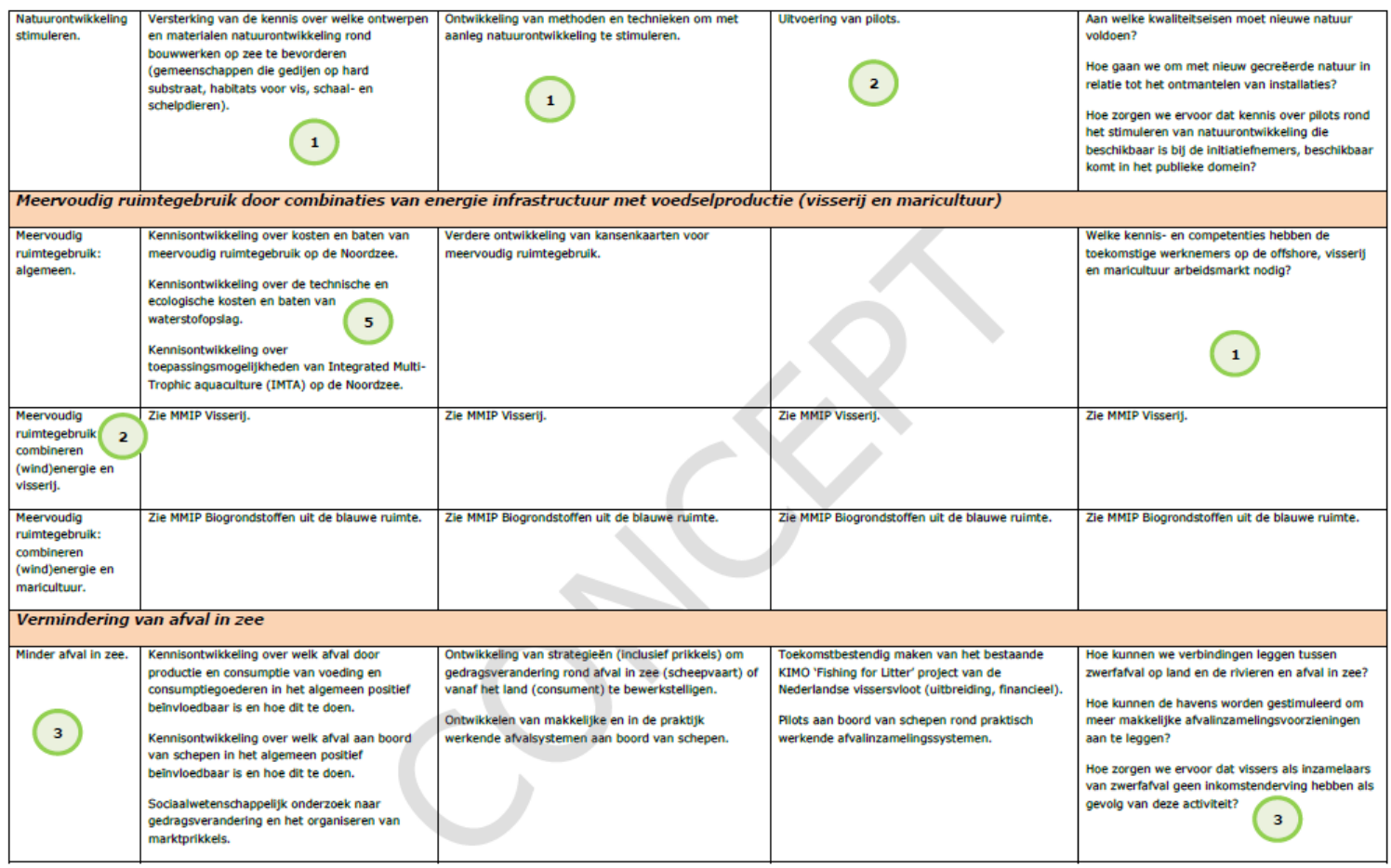

Prioritering stakeholders concept-MMIP Zeewier

Deelprogramma's en fasering innovatietraject MMIP Zeewier

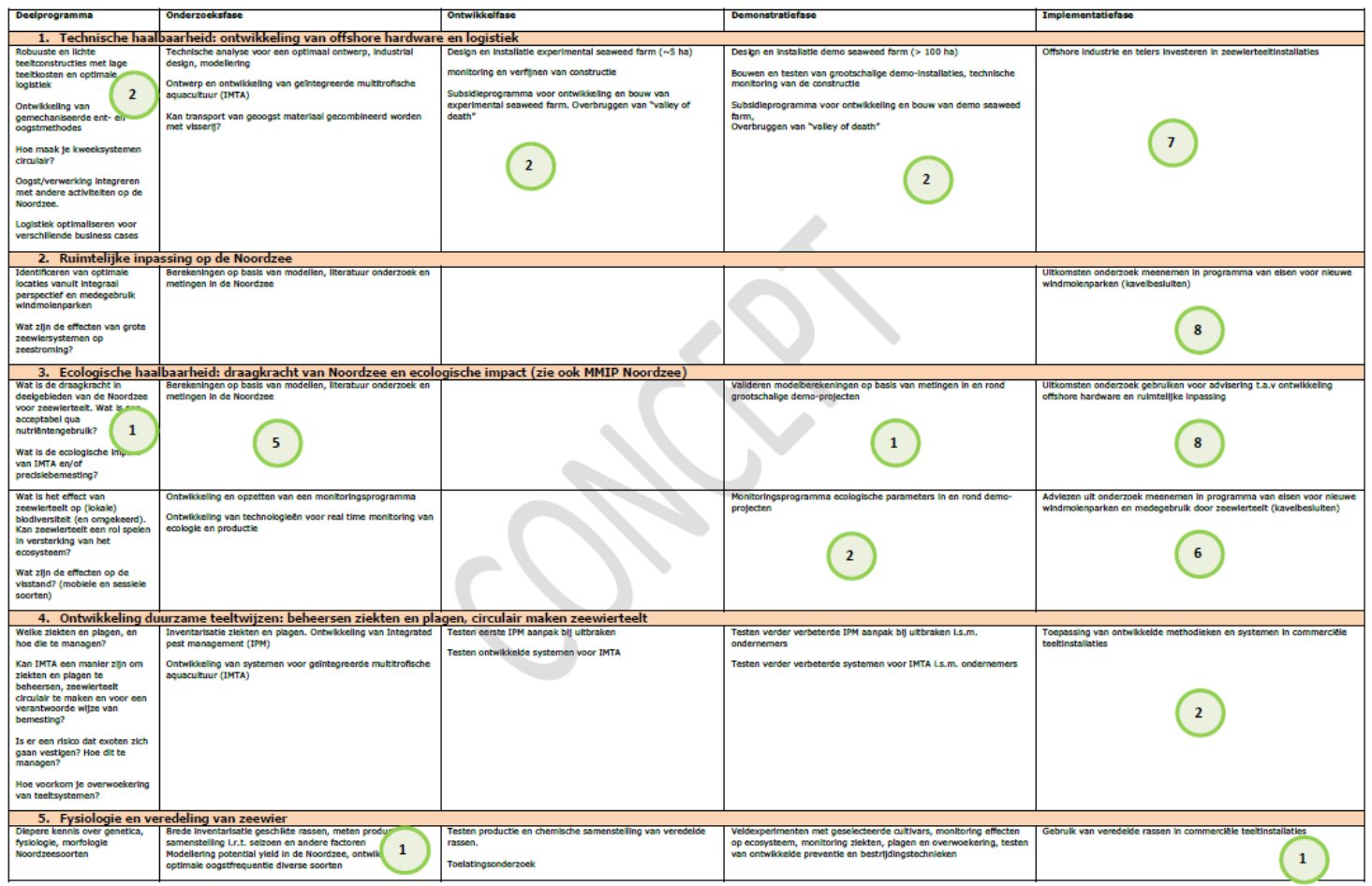

(loopt door op volgende pagina) 
(vervolg vorige pagina)

\begin{tabular}{|c|c|c|c|c|}
\hline 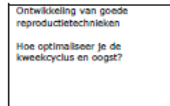 & 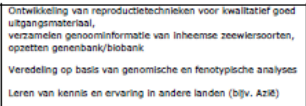 & & & \\
\hline 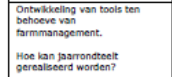 & 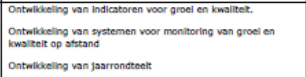 & 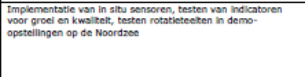 & 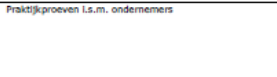 & 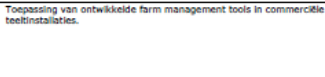 \\
\hline 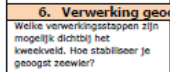 & 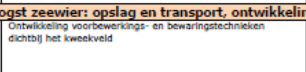 & 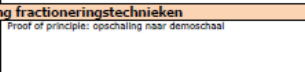 & 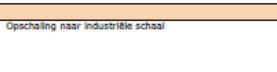 & \\
\hline 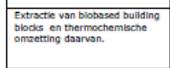 & 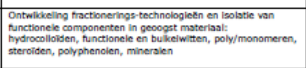 & 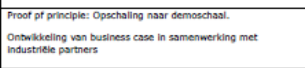 & 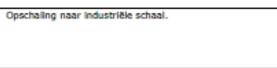 & 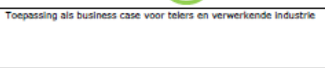 \\
\hline 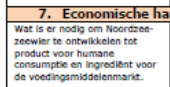 & 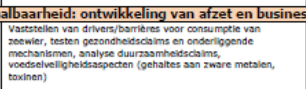 & 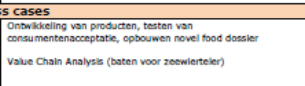 & 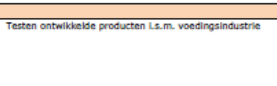 & 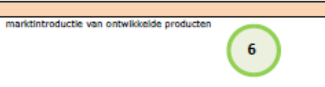 \\
\hline 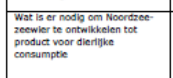 & 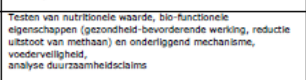 & 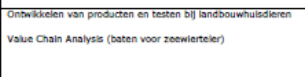 & 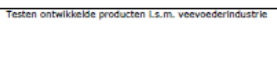 & markitintroductere van ontw \\
\hline 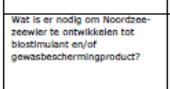 & 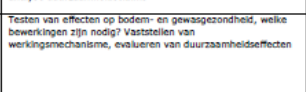 & 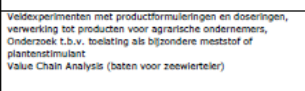 & 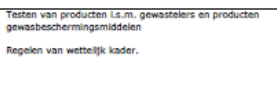 & 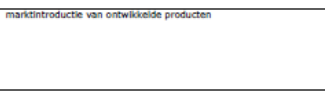 \\
\hline 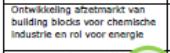 & 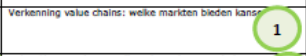 & 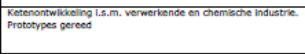 & 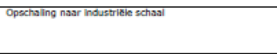 & \\
\hline 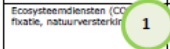 & 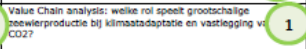 & & & \\
\hline 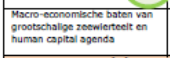 & 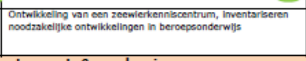 & & & \\
\hline 8. Bestuurlijke aspe & ecten, wet- \& regelgeving & & & \\
\hline 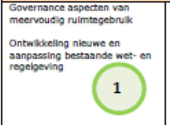 & 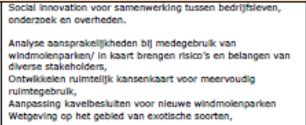 & 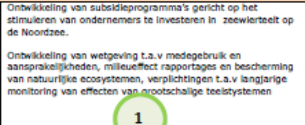 & & \\
\hline
\end{tabular}


Prioritering stakeholders concept-MMIP Verduurzaming zee- en kustvisserij Noordzee (loopt door op volgende pagina)

\begin{tabular}{|c|c|c|c|}
\hline Onderzoeksfase & Ontwikkelfase & Demonstratiefase & Implementatiefase \\
\hline \multicolumn{4}{|c|}{ Missie: Verduurzaming van de zee- en kustvisserij op de Noordzee } \\
\hline $\begin{array}{l}\text {-Verbeteren van de toegepaste kennisbasis voor het beheer } \\
\text { van gegevensarme bestanden (veelal commerciële } \\
\text { bijvangstsoorten) } \\
\text { - Ontwikkelen van fundamentele kennis over de verspreiding } \\
\text { van visbestanden (en de gevolgen voor maximaal duurzame } \\
\text { oogst mogelijkheden) als gevolg van klimaatverandering } \\
\text { - versterking van (gedragseconomische) kennis over } \\
\text { visserijgedrag om zo de effecten van "verplaatsingsgedrag" } \\
\text { (displacement) op bestanden, ecosysteem en rentabiliteit als } \\
\text { geval van gebiedssluitingen (natuur, windparken) beter } \\
\text { vooraf te kunnen voorspellen. } \\
\text { - Ontwikkelen van fundamentele kennis in het toepassen van } \\
\text { een ecosysteembenadering in het bepalen van TACs en } \\
\text { quota } \\
\text { - Fundamenteel onderzoek naar de effecten van de } \\
\text { aanlandplicht }\end{array}$ & \begin{tabular}{|l}
-Ontwikkelen van innovatieve \\
bemonsterings- en monitoringsmethodes \\
voor gegevensarme bestanden (DNA- \\
technieken, cameradetectie met \\
automatische beeldherkenning)*. \\
\\
\end{tabular} & \begin{tabular}{|l|}
-Uitvoeren van proefprojecten in nauwe \\
samenwerking tussen de visserijsector en \\
onderzoekers, waarbij directe verbinding met ICES \\
essentieel is. \\
- Uitvoeren van scenariomodellen m.b.t. \\
verandering in visserijgedrag en de effecten op \\
bestanden, ecosysteem en rentabiliteit.
\end{tabular} & $\begin{array}{l}\text {-Welke financiering en aanpalende } \\
\text { maatregelen zijn nodig om succesvolle } \\
\text { nieuwe visstand-onderzoektechnieken } \\
\text { standaard onderdeel te maken van het } \\
\text { visserijonderzoek. }\end{array}$ \\
\hline \multicolumn{4}{|l|}{ Verbetering selectiviteit } \\
\hline $\begin{array}{l}\text { - Versterken fundamentele kennis van visgedrag in het } \\
\text { algemeen (visgedrag voor het vistuig, wanneer het schip } \\
\text { aankomt, in het net) } \\
\text { - Inzicht in (mogelijk veranderende) verspreiding van } \\
\text { commercièle en niet-commerciêle soorten }\end{array}$ & $\begin{array}{l}\text { - Ontwikkelen van (radicale) innovatieve } \\
\text { vistechnieken en netten op basis van } \\
\text { visgedrag gericht op het vangen van } \\
\text { doelsoorten alleen*. } \\
\text { - Ontwikkelen van precisie visserij } \\
\text { technieken (camera detectie, sonar } \\
\text { detectie, etc.)*. } \\
\text { - Ontwikkelen hightech oplossingen die real } \\
\text { time informatie over visserij en vangsten } \\
\text { leveren en voorspelbaarheid van locatie } \\
\text { van visbestanden kan verbeteren*. } \\
\text { - Vaststellen van ecologische effecten van } \\
\text { nieuw ontwikkelde vistechnieken } \\
\text { - Vaststellen van socio-economische } \\
\text { effecten van nieuw ontwikkelde } \\
\text { vistechnieken } \\
\text { - Benutting en versterking van het visserij } \\
\text { Innovatiecentrum en de samenwerking met } \\
\text { visserijcoöperaties en toeleveranciers }\end{array}$ & \begin{tabular}{|l|} 
- Uitvoeren van pilots van nieuwe vistechnieken \\
om inzicht te krijgen in praktische haalbaarheid en \\
rentabiliteit, warbij zorg wordt gedragen voor \\
nationaal én internationaal draagvlak \\
-Uitbouw Visserij Innovatie Centrum als spil voor \\
innovatie pilots \\
\end{tabular} & $\begin{array}{l}\text { - Hoe kan ruimte (financieel, regelgeving) } \\
\text { gegeven worden aan visserijondernemers } \\
\text { om te kunnen innoveren }\end{array}$ \\
\hline \multicolumn{4}{|l|}{ Vermindering bodemberoering } \\
\hline $\begin{array}{l}\text { - Versterken fundamentele kennisontwikkeling van het } \\
\text { bodemecosysteem en identificatie van de kwetsbare } \\
\text { gebieden op de Noordzee } \\
\text { - versterken toegepast kennisontwikkeling in input-systemen } \\
\text { (credits, quota) om minder in kwetsbare gebieden te vissen. } \\
\text { - in hoeverre zijn gebieden met een hoge bodemdynamiek } \\
\text { interessant voor de visserij (vangst, doelsoorten, } \\
\text { bereikbaarheid) } \\
\text { - Fundamenteel en toegepast onderzoek gericht op } \\
\text { vloottransitie dat bijdraagt aan vermindering van } \\
\text { bodemberoering. } \\
\text {-Fundamenteel en toegepast onderzoek naar vissen op basis } \\
\text { van 'efficiëntie', (niet alleen MSY) zoals hoeveelheid } \\
\text { bodemberoering/kg vis, cO2 per kg/vis, etc. } \\
\text { - versterken kennis over hersteltijden per bodemtype } \\
\text { (dynamisch/niet dynamisch) na bevissing met } \\
\text { bodemberoerende vistuig } \\
\text { - versterken fundamenteel inzicht in het effect van } \\
\text { bodemberoering van verschillende ingrepen (visserij, } \\
\text { zandwinning etc) op de Noordzee }\end{array}$ & $\begin{array}{l}\text { - Ontwikkelen van innovatieve } \\
\text { vistechnieken met minder } \\
\text { bodemberoering*. } \\
\text { - Vaststellen van ecologische effecten van } \\
\text { nieuw ontwikkelde vistechnieken*. } \\
\text { - Vaststellen van socio-economische } \\
\text { effecten van nieuw ontwikkelde } \\
\text { vistechnieken. }\end{array}$ & \begin{tabular}{|l|} 
- Uitvoeren van pilots van nieuwe vistechnieken \\
om inzicht te krijgen in praktische haalbaarheid en \\
rentabiliteit, waarbij zorg wordt gedragen voor \\
nationaal én internationaal draagvlak \\
- Realiseren van Europees commitment \& \\
draagvlak bij het toepassen van input-systemen \\
om minder in kwetsbare gebieden te vissen i.v.m. \\
jurisdictie.
\end{tabular} & $\begin{array}{l}\text { - Hoe kan ruimte (financieel, regelgeving) } \\
\text { gegeven worden aan visserijondernemers } \\
\text { om te kunnen innoveren } \\
\text { - Welke controle \& handhaving } \\
\text { maatregelen kunnen toegepast worden } \\
\end{array}$ \\
\hline \multicolumn{4}{|l|}{ Vermindering emissies } \\
\hline
\end{tabular}


(vervolg van vorige pagina)

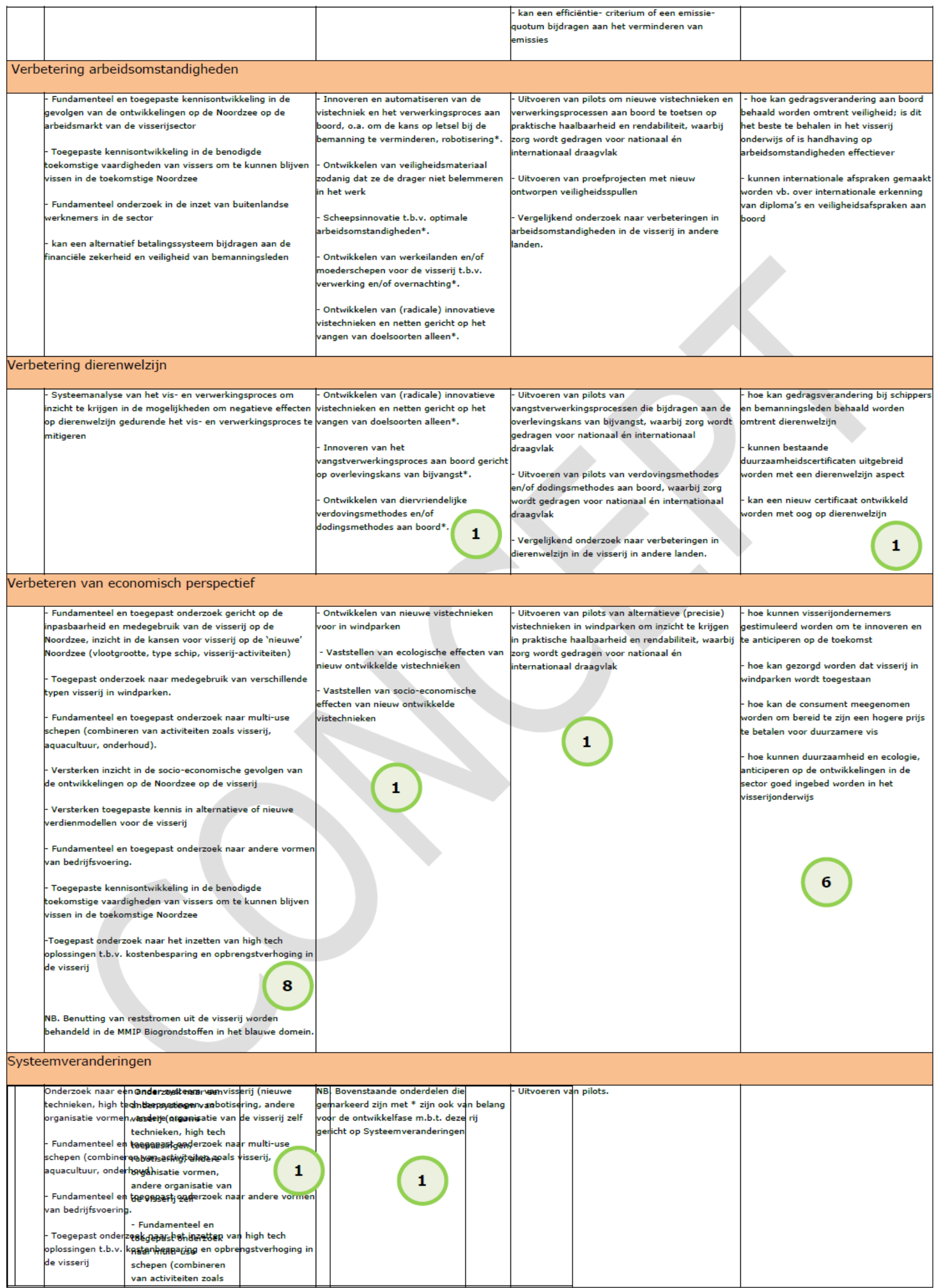

(einde)

\section{Werksessies kennis en innovatiecases}

In de middag werd er in twee rondes in groepen gewerkt aan een kennis- of innovatiecase. De bedoeling was om inzicht te krijgen wat de deelnemers dachten nodig te hebben om iedere casus te realiseren en welke rol zij zelf hierin kunnen spelen. Na een twee minuten pitch van vier cases die 
allemaal een relatie met de concept-MMIPs hadden, konden de deelnemers konden zelf kiezen met welke casus ze aan de slag wilden.

De volgende casussen werden ingebracht

1. Kennisproject: draagkracht Noordzee, door Sharon Tatman, Deltares, i.s.m. Nathalie Steins (WMR, Wageningen Marine Research).

2. Kennis-/ innovatieproject: ontwikkeling nieuwe onderwatermonitoring technieken voor natuur in een windpark (Bram Couperus, WMR)

3. Innovatieproject: natuurherstel en maricultuur in een windpark (Oscar Bos, WMR, Ineke Ammerlaan, WUR)

4. Innovatieproject: de zero impact viskotter (Pieke Molenaar, WMR, i.s.m. Klaas Visser TU Delft (niet aanwezig)

Hieronder worden de resultaten van de deelsessies besproken. De namen en organisaties van de deelnemers zijn genoteerd, maar de verslaglegging is anoniem gebeurd.

\section{Sessie 1: Draagkracht Noordzee}

Sharon Tatman (Deltares) en Nathalie Steins (Wageningen Marine Research) leiden deze sessie. Zij willen een voorstel uitwerken voor een onderzoeksproject rond de draagkracht van de Noordzee. Er ligt een grote ambitie voor de uitrol van wind op zee tot 2030 maar ook daarna. Maar is er wel genoeg wind voor al die windmolens? Bij een te grote uitbreiding van windparken op zee kan de wind een beperkende factor worden, wat niet alleen economische effecten heeft voor de windenergiebedrijven. Een opschaling van windparken op zee kan ook fysische effecten geven zoals het verminderen van enerzijds de gemiddelde windsnelheden en daarmee ook golfhoogtes. Anderzijds veroorzaakt de aanwezigheid van de palen van turbines veel menging van de waterkolom. Beide processen hebben invloed op opwerveling van slib en dus op doorzicht en dit soort fysische effecten kunnen in theorie grote gevolgen hebben voor de stratificatie van de waterkolom en uiteindelijk de ecologie van de Noordzee. De stevige ambities van Nederland rond de winning van wind op zee brengen dus risico's voor het ecosysteem met zich mee. Hetzelfde geldt voor de ambities rond het vergroten van de voedselproductie uit zee via maricultures, zoals zeewier.

\section{Ronde 1}

\section{Deelnemers}

Amber Koertshuis - TKI wind op zee; Rob vd Veer - Rijkswaterstaat WVL, is o.a. betrokken bij OSPAR economie; Pim Vugteveen - PBL; Nathalie Scheidegger - LNV, voor een deel aanwezig); Nathalie Steins - WMR; Sharon Tatman - Deltares.

Zijn er kennisleemtes die op de MMIP Noordzee niet zijn aangegeven of kennis- en innovatievragen die prioriteit verdienen?

- Natuurlijk kapitaal: In recente studie is een inventarisatie gedaan naar beschikbaarheid van basisgegevens voor KRM-indicatoren. Is er een goed (genoeg) dekkend beeld van de indicatoren en relevante parameters van de Noordzee? KRM-indicatoren worden nu niet geografisch Noordzeedekkend gemeten maar puntsgewijs zonder echt plan daarvoor. Dus er moet minder alles overal meten maar slimmer meten, oftewel beter ruimtelijk gedifferentieerd.

- Kosten-baten: Wat zijn de KB van de maatregelen die we in de nabije toekomst gaan treffen? Bv. als we de Oestergronden en Front sluiten voor bodemberoerende visserij, wat gebeurt er dan met de ecologie en economie. Er is niet genoeg kwantitatieve kennis over de kosten-baten van wat precies te verwachten van maatregelen.

- Conflicterende / andere dynamische proces tussen kennisontwikkeling en de snelheid beleidsambities en de uitrol ervan. Hoe kunnen we betere uitspraken doen over de richting van beleid en ervoor zorgen dat op tijd de kennisvragen worden beantwoord? Hoe voorkomen we dat we niet op tijd de juiste antwoorden hebben. Meer doen met risico's inschatting i.p.v. alleen effectbeoordelingen die we niet altijd kunnen beantwoorden? De KRM-aanpak is altijd geweest: 'hand op de knop', oftewel KRM-maatregelen uitvoeren en laten gebeuren en ingrijpen zodra nodig is.

- Voor systeemkennis en betere kwantificering van informatie, zijn meer modellen nodig. Dit in combinatie met klimaatverandering modellen: hydrodynamica, wind, etc. 
- Meer aandacht voor ecosysteemdiensten.

- Meer aandacht voor cumulatieve effecten voor WOZ. Wat wordt impacts op plankton?

- Gebrek aan natuurlijke referentie gebieden.

- Gebrek aan streefdoelen zoals bv. de Goede Kwaliteit van KRM (omdat we de oorspronkelijke "goede kwaliteit" de Noordzee uit het verleden niet weten en niet tot die staat kunnen terugkeren). Dus i.p.v. richten op onrealistische streefdoelen, meer richten op het oplossen/ omkeren van negatieve effecten. Als je doel niet weet, kun je wel richting aangeven.

- Passen de huidige doelstellingen bij nu? KRM wil bepaalde ecologische kwaliteit stimuleren. Past dat bij huidige beleidsambities? Welk soort natuur wil je hebben? In combinatie met nieuwe infrastructuur.

Zien de deelnemers rollen voor zichzelf / hun organisatie in een nieuw integraal project over Noordzee Draagkracht?

- $\quad$ Rijkswaterstaat: betrekken vanuit rol in OSPAR als klankbord.

- TKI: is bezig met integratie in MMIPs. Zit aan vraagstellingskant. Vooral betrekken als gaat over lange termijn effecten windmolens.

- PBL: wil aftappen van wat uit onderzoek komt. Bv. effecten van maatregelen en beleidsrelevantie.

\section{Financiering}

- $\quad$ Monitoring is vereist vanuit vergunningverlening. I.p.v. verplichten van monitoring heel lokaal bv. binnen het windpark, verplicht het financieren van bijdrage in een fonds dat besteedt kan worden aan het ontwikkelen van een integraal monitoringsplan. Daarmee monitoren in gebieden buiten de windpark.

\section{Nabrander}

Shell heeft veel data van boorplatforms.

\section{Ronde 2}

\section{Deelnemers}

Bert Fokkema - Shell (decomissioning olie en gas); Linda van Bets - Wing (vanuit opdracht voor PBL rond wat het betekent als grote wateren opnieuw worden opgenomen in de natuurbalans); Han Lindeboom - emeritus hoogleraar WUR/zelfstandig adviseur; Klaas Jan Wardenaar - Smartland. (ecoloog en ontwerper, o.a. van Markerwadden); Gerd de Kruijff -secretaris overleg Noordzeeakkoord; Nathalie Steins - WMR.

Zijn er kennisleemtes die op de MMIP Noordzee niet zijn aangegeven of kennis- en innovatievragen die prioriteit verdienen?

- Bijdrage van man-made structuren aan ecologie en economie en dit gebruiken bij plannen en denken over wind.

- Op Noordzee intelligenter gaan nadenken over gebruik met ecologische ontwikkelingen daar achter als ecoloog.

- Wat is de baseline? Waar zitten we nu? Is er een baseline?

- Passen de huidige doelstellingen voor natuur, etc. nog ?

- $\quad$ De Noordzee bestaat uit verschillende gebieden en activiteiten hebben dus verschillende impacts. Hoe verdisconteer je dat?

- Heel veel gaat over productie van $14.000 \mathrm{~km} 2$ zeewier. Maar als je dat wil dan moeten ze in Duitsland stoppen met de zuivering van het rivierwater. Gaat het om productiedoelstelling met natuurherstel of gaat het om natuurdoelstellingen met menselijk medegebruik?

- Spanning tussen kennis en de beleidsontwikkelingen. Andere manier van effectbeoordeling?

- We meten al 130 jaar. We weten al veel wel. Strakke baseline bestaat eigenlijk niet. We hebben veel wensen en o.b.v. die wensen kun je plaatjes en scenario's maken. De vraag die je zou moeten meenemen daarin is: welke rol speelt de mens per $\mathrm{km} 2$ in het systeem?

- Kun je Goede milieutoestand gebruiken? Dat is schieten op een bewegend doel.

- Noodzaak voor referentiegebieden. In 1995 is hier al een publicatie over geweest; ook is er een plan van aanpak.

- We maken in Nederland natuur, o.a. Markerwadden. Veel goede verhalen. Maar is dat in de Noordzee ook zo? Maken we een mooier gebied? De natuur in de Noordzee is misschien wel saai 
van zand, nu breng je hard substraat in en dat is nep. Er zit wel degelijk herstelpotentieel o.a. voor oesters in de Noordzee. Ook vondst sabellariariffen in Bruine Bank. Hypothese is dat als je maar lang genoeg niet vist, dan treedt herstel op.

- Het Markermeer onnatuurlijk systeem. Er is gekeken naar ander wetland als referentie en daar is Markerwadden op gebaseerd. Heb je zo'n referentie voor de Noordzee? Noordzee is unieke zee; we begrijpen de processen een beetje. Terugblikken naar verleden geen zin. We moeten vooruitblikken.

- $\quad$ Als het lukt om oesters te herstellen naar het niveau van eind $19^{\mathrm{e}}$ eeuw, dan zal de Noordzee er anders uitzien (helderder water door filtratiecapaciteit). Het credo is nu 'alles wat natuur helpt is goed', maar ook dat soort processen zullen optreden. De vraag is of iedereen daar achter staat? Accepteer dat de mens ook een positief effect kan hebben en waardeer antropocene natuur.

- Laat afgeschreven platformen staan, maar onder voorwaarde dat er voortdurende monitoring is.

- Debat over visserij in windparken wordt beheerst door kabels. Kun je niet veel meer precisievissen? Meer technologie inzetten.

- Offshore service eiland als toevoeging aan het systeem.

Als onderdeel van de discussie wordt gevraagd hoe het MMIP Noordzee linkt aan het ingediende NWA voorstel North Sea In Transition. Han Lindeboom geeft een korte toelichting. Het voorstel richt zich op energie, draagkracht, voedsel en 'enabling change' (governance). In totaal doen 83 partners verdeeld over 22 instituties mee. Begin juni weten we of het doorgaat. Als het niet doorgaat, hebben we nu alvast een nieuw preproposal ingediend getiteld: Future North Sea: is the sky the limit? Nathalie Steins vult aan dat van de 148 witte vlekken in de kennis- en innovatievragen voor de Noordzee, er 68 worden aangepakt binnen het North Sea In Transition project.

Zien de deelnemers rollen voor zichzelf / hun organisatie in een nieuw integraal project over Noordzee Draagkracht?

- Shell: potentieel om platformen te laten staan en te monitoren. De data van al onze monitoring is er en die wordt niet voldoende gebruikt. Oorzaken zijn: juridisch, waan van de dag die gericht is op operationele zaken. Zet geld in als smeermiddel om data te genereren, bijvoorbeeld via het Noordzeefonds. Installaties verplichten om data te delen/publiek te maken.

- Wing: ziet geen rol voor zichzelf maar adviseert om samenwerking met windparken en olieplatforms op rond dataverzameling.

- Han Lindeboom: wil gezamenlijk projectvoorstel met vissers en overheid willen indienen en gezamenlijk de kennisvraag ontwikkeling (o.a. leren van hoe het niet goed gegaan is bij het voorstel van het project Wadden mozaïek). Het idee van visser Dirk Kraak over combinatie van sleepnetvissen in een windpark met natuur, zoals aan het overleg Noordzeeakkoord is gepresenteerd, zou een aanknopingspunt kunnen zijn.

- Han Lindeboom adviseert om gebruik te maken van sociale wetenschappen als je dit soort ontwikkelingen op de Noordzee wilt. Bijv. Enabling change in North Sea In Transition voorstel.

- Smartland: Bijdragen aan communicatie multifunctionalitiet. Maatschappelijke acceptatie helpt ook in politieke proces.

- $\quad$ OFL: Je moet echt goed naar de governance gaan kijken als je dit allemaal echt zo belangrijk vindt. Dat is iets wat OFL meeneemt. Monitoring is belangrijk.

\section{Sessie 2: Nieuwe onderwatermonitoring technieken voor natuur in een windpark}

Bram Couperus (Wageningen Marine Research, WMR) wil werken aan een projectvoorstel over de aanleg van een snelle dataverbinding naar een of meer permanente op afstand bedienbare meetstations in de windparken. Hier kunnen permanent allerlei verschillende soorten data gelogd worden welke door verschillende partijen gebruikt kunnen worden. Het grote voordeel van dit model zou zijn dat er geen er geen geld en (scheeps)tijd hoeft te worden besteed aan het tijdelijk inzetten van meetinstrumenten, waarvan op het moment van de metingen ook niet te zien is of alles goed werkt en of er instellingen zouden moeten worden aangepast.

\section{Deelnemers}

Sessie 1: David Geurts -Deltares (student, onderzoekt netwerk stakeholders Noordzee); Hein Sas zelfstandige (Mariene Natuurverbetering, Waddenzee, Noordzee; trekker platte oesterconsortium); 
Antoinette Charnier - RVO (betrokken bij CoP); Yves Verschueren - Boskalis (innovatie manager); Bram Couperus, WMR

Sessie 2: Bob Meijer -TKI Wind op Zee directeur (beheert 150mln onderzoeksgeld); Marnix Poelman WMR (blauwe groei, nieuwe kennisontwikkeling); Michael Laterveer - Blue Linked (viskweker; m.n. haaien en roggen); Ronald Rense - RWS, WVL, BOA Noordzee;

Samenvatting van de bevindingen (beide sessies)

- $\quad$ Op zich ziet men wel een datavraag: bijvoorbeeld monitoring van activiteit van tweekleppigen (Hein sas), biochemische metingen, visuele metingen van wat er leeft op het substraat en aangroeisel (dit gebeurt nu met een ROV vanaf een onderhoudsboot).

- Bestaande glasvezel is heel specifiek voor onderhoudsdoeleinden, beperkte capaciteit en niet te gebruiken voor de voorgestelde doeleinden. Aanleg van een glasvezelkabel is erg duur. Niet realistisch. Er wordt gesuggereerd om een straalverbinding aan te leggen. Is veel goedkoper maar heeft een beperkte bandbreedte. Aan de andere kant worden er op termijn info- en trafostations geïnstalleerd welke ook mogelijkheden bieden voor dataoverdracht.

- Aan de andere kant: data zijn duur. En als de bedrijven de zekerheid hebben dat data worden afgenomen, dan is er veel mogelijk.

- Advies is om een matrix te maken waarin je invult welke partijen wat willen, wat de kosten zijn en wat er nodig is. Daarnaast zou men eens moeten praten met de innovatie managers van de windpark eigenaren: Siemens, Nuon, Wattenval, (Eneco is minder geschikt).

- Het is belangrijk om je te realiseren dat er al een meetpaal heeft gestaan waarin 7 miljoen werd geïnvesteerd. Bij gebrek aan vraag naar data en geld is deze nu weggehaald. Deze meetpaal verzamelde overigens alleen gegevens boven water.

- Het idee is dat er wel behoefte is aan data en dat deze waardevoller worden doordat ze simultaan met andere data worden verzameld. Het probleem is dat niemand van te voren wil investeren, omdat het niet zeker of het zich terugbetaald en vooral in hoeverre het zich terugbetaald voor de betreffende investeerder. De kunst is om de behoeften in kaart te brengen en duidelijk te maken wie er aan wat voor data behoefte heeft en wie daarvoor zou willen betalen, zonder dat er op dit moment concrete vragen liggen.

- $\quad$ Een belangrijk issue is dat er op dit moment toch al boten voor onderhoud varen. Dit blijft noodzakelijk. De beschikbaarheid van deze onderhoudsboten maakt investering in directe dataverbindingen onaantrekkelijk.

Lijst van mogelijke sensoren en data:

- $\quad$ Meten activiteit van tweekleppigen (bijv. in oesterkwekerij)

- E-DNA

- ROV voor onderhoud en camera opnamen in de buurt van het station

- Ontvangststation gezenderde vissen

- Basisgegevens: zoutgehalte, temperatuur, chlorofyl, nutriënten, golfhoogte, ...

- $\quad$ Lidar (onder meer voor windsnelheid)

- ADCP: stroming

- $\quad$ Echolood en Sonar: biomassa en gedrag van vis en plankton

- Drone vanuit basisstation: deze zou transecten kunnen varen met diverse sensors

- Vogelradar

- $\quad$ Detectie stations voor (gezenderde) vleermuizen

\section{Sessie 3: Zeewier en natuurherstel}

Het doel van deze sessie is het aanscherpen van het MMIP Zeewier, met als nieuw element natuurherstel. Ook andere vormen van medegebruik (multiuse) zijn bediscussieerd.

Ronde 1

Deelnemers: In een uitgebreid voorstelrondje hebben aanwezigen hun expertise naar voren gebracht die in dit verband nuttig was. In het kort: 
- Noordzeeboerderij: platform voor 90 organisaties, wil in de nabije toekomst $500 \mathrm{~km} 2$ zeewier kweken. Zij zien een combinatie met oesterherstel zitten. Hebben een testlocatie offshore buiten Scheveningen te bieden waar pilots getest kunnen worden.

- Seaweed kwekerij: kweekt al zeewier in de Oosterschelde, verbinding met WUR aanwezig. Wil 100.000 ha zeewier, kosten 800 miljoen. Grootschalige pilots ook over zaai- en oogsttechnieken.

- CoP: organisator van de bijeenkomst.

- $\quad$ RVO: kent de weg naar de regelingen en EU-subsidies (o.a. innovatiefonds Aquacultuur). Overzicht staat op posters.

- Van Oord (student TU Twente): doet onderzoek naar multi-use (kosten/baten ecosysteem), resultaat is na de zomer beschikbaar.

- Wageningen Marine Research (project Win-Wind): onderzoekt mogelijkheden voor vissen op kreeften en krabben in windparken. Combi met zeewier en oesters?

- Blue Linked: Circulaire viskwekerij. Kan elke soort vis kweken (niet alleen roggen en haaien) voor natuurherstel (pootvis, bijv. kabeljauw). Zoekt naar low-profile onderzoeksplatform (Noordzeescheepje waarvan meerdere organisaties gebruik kunnen maken). Wil idee van "scharrelvis" wegzetten. Moeilijkheid: nu moet per soort een vergunning aangevraagd worden voor terugzetting, ook al komt bronmateriaal (eieren) uit zee.

- $\quad$ Min EZK:

- MARIN: Kan drijvende dingen (bijv. zeewierkweekfaciliteiten) testen op schaal in relatie tot weer/golven/etc.

- WNF: wil een rendabiliteit testen van een verdienmodel op een proeflocatie met 100 ha oesterbanken, eventueel in combinatie met zeewier. Heeft al contact met zeewier stakeholders. Project gaat over kweek bronmateriaal, ruimte, financiering, etc. Vraag is waar we elkaar kunnen vinden in ecosysteemdiensten.

- SeaGoingGreen: bedrijfje in Amsterdam dat een extra laag in scheepvaartnavigatiekaarten wil maken met ecologische informatie t.b.v. scheepvaart.

\section{Kennisvragen:}

- Wat is het omslagpunt waarbij een oesterbank zichzelf in stand houdt? (Hoe groot (ha) moet je ze bouwen).

- Versterken oesterbanken en zeewier elkaar?

- Zijn er businessmodellen voor zeewierkweek en natuurherstel?

- Welke functiecombinaties van ecologie en economie zijn haalbaar?

- Kunnen windparken vanaf de tekentafel integraal ontworpen worden, rekening houdend met ander gebruik (bv kabels moeten diep genoeg liggen i.v.m. bodemvisserij; kabels moeten parallel liggen i.v.m. aansluiting zonne/golfenergie (vermijden crossing)).

- $\quad$ Is er een effect van golfdemping door zeewierkweek op windturbinepalen, of van windturbinepalen op zeewierkweek, en welke voordelen heeft dit (vergroting aantal werkbare dagen, verlengde levensduur turbinepalen).

- Check Belgische studies, die zijn al een stuk verder : EDULIS (http://www.aqua.ugent.be/edulis), BELWIND ((Universiteit Gent).

- Checken of MMIP duidelijke tekst bevat over belang fundamenteel onderzoek.

- Mosselkweek: is er een oogstmethode denkbaar waarbij mosselen aan boord gekookt worden, om de lege schelpen direct weer uit te kunnen strooien als settlement-substraat?

- $\quad$ Kan er wetgeving gemaakt worden voor het terugzetten van kweeksoorten (kweek uit natuurlijke bronnen, zoals roggen uit aangespoelde roggeneieren)

- Wat zijn de effecten van de omgeving (golven, stroming) op de combinatie van zonneenergiepanelen, windmolenpalen en zeewierkweek (d.m.v. schaalmodeltesten door MARIN)? (in elkaars beschutting?)

\section{Ronde 2}

Deelnemers

- Van Oord: betrokken bij alle windparken die gebouwd worden. Volop bezig met platte oester. Luchterduinen, Borssele 3, 4. Kavelbesluit met inspanningsverplichting: platte oester herstel. Afstudeerder die kijkt naar alle medegebruik mogelijkheden (wet - en regelgeving).

- $\quad$ TKI Wind op Zee: meerjarenplan nodig (routekaarten) en gemeenschappelijk programma. 
- VisNed: Heeft belangstelling voor de nieuwe vormen van gebruik (maar voor vissers moet er ook plek zijn).

- $\quad$ RVO: Is het MKB bankje van de overheid. Voorlichting over innovatie fondsen. Let op: overheid financiert nooit alleen. 'samen staan we sterker' $1+1=3$

- SLOW MILL (http://www.slowmill.nl/): Maakt golfenergie. Constructies zitten vast aan 50 ton betonnen anker (voor kust Texel), 4-5 km uit de kust. In 2020 een anker van 300 ton.

Mogelijkheden: gebied rondom anker kan gebruikt worden als proeflocatie. In luwte van park zou je zeewier kunnen kweken.

- Noordzeeboerderij (https://www.noordzeeboerderij.nl/): toekomstbeeld: 2030: 500 km2 zeewier.

\section{Kennisvragen:}

- Wat is economische haalbaarheid van een combinatie zeewierkweek-oesterherstel?

- Wat is effect van zeewierkweek- en oesterherstel op het ecosysteem? (voedselbron of voedselconcurrent voor vissen), en hoe toon je dit aan?

- $\quad$ Input voor MMIP: maak missie voor zeewier duidelijker (i.p.v. 14000 km2)

- Moet de missie voor zeewier perse binnen windparken gevonden worden?

- $\quad$ Hoe kunnen de verzekeringskosten omlaag voor activiteiten die nabij windparken plaatsvinden? (als visser nu in de buurt van een windpark komt, en een turbinepaal blijkt beschadigd, kan een visser een claim verwachten, ook al heeft hij de paal niet geraakt)

- Zou de overheid verzekeringskosten niet kunnen financieren?

- Zorgt schelpdierproductie lokaal voor extra nutriënten productie?

- Hoe wordt zeewier gewaardeerd? (welke grondstoffen)

- Kunnen toekomstige Wind-op-Zee gebieden vooraf ontwikkelen, in plaats van achteraf? (net als op land).

- Kun je een pachtconstructie bedenken voor zeewier-boeren?

- Kan 'oesterstroom' als premium product verkocht worden?

- Kan er een Routekaart Oesterbanken gemaakt worden?

- Kan er een Routekaart Zeewierkweek gemaakt worden?

- Is omscholing van traditionele vissers naar multi-use vissers mogelijk?

\section{Sessie 4: Innovatiecasus 'Zero emission and minimal impact kotter'}

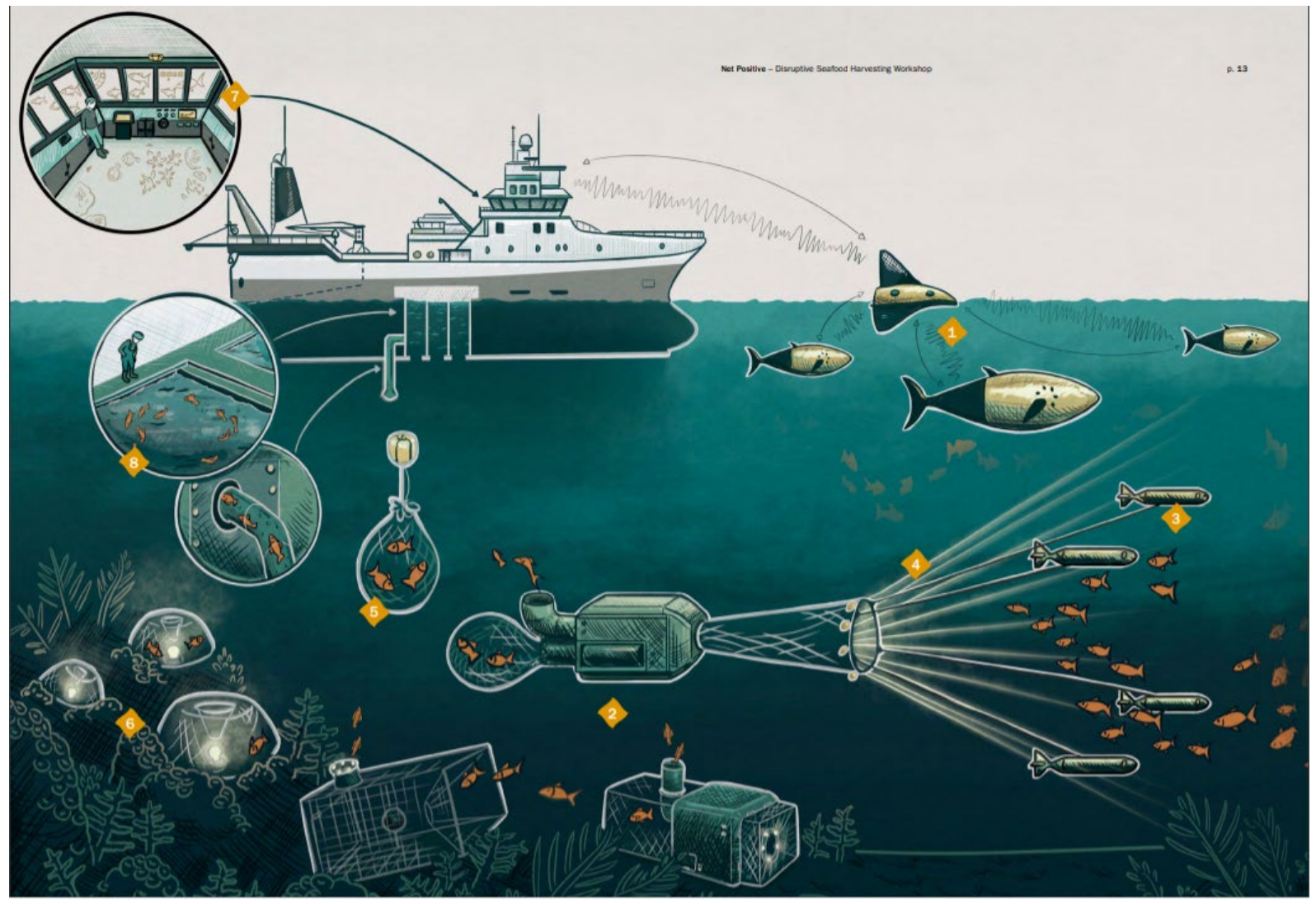


De inleiding van de sessie werd gedaan aan de hand van de bovenstaande tekening waarin ideeën voor toekomstige visserij (technieken en methoden) geschetst zijn. Een uitgebreide beschrijving van de genummerde onderdelen is terug te vinden op:

https://www.seafish.org/media/publications/NetPositiveReport_2508_v2.pdf

\section{Sessie 1}

De deelnemers werden gekenmerkt door een brede verscheidenheid, van subsidie adviseurs tot beleidsmedewerkers RVO/LNV. Geen deelnemers met technische achtergrond of visserij achtergrond.

\section{Bevindingen}

\section{Brandstoftransitie \& koeling}

De deelnemers waren overtuigd dat ingezet moet worden op een kotter waarbij alle processen aangedreven worden door waterstof. Hierdoor dient een $\mathrm{H} 2$ motor en veilige opslag van $\mathrm{H} 2$ aan boord ontwikkeld te worden en het ombouwen van kotters dient gestimuleerd te worden. In Lauwersoog heeft de visserijsector de ambitie om de eerste waterstof kottervloot te worden, hier zou aansluiting bij gezocht kunnen worden. Voor het ontwerp en engineering van opslag aan boord en in de haven en distributie zou "FLUOR" een kandidaat zijn, leverancier van waterstof gegenereerd door windmolens op zee zou aan NUON gedacht kunnen worden.

\section{Stopcontact op zee}

Elektrisch varen zou eventueel een andere optie zijn, hierbij wordt aangegeven dat er meegekeken moet worden bij de huidige ontwikkelingen in de vliegtuigindustrie om deze technologieën ook in de visserij te passen. De elektriciteit wordt verkregen in een windmolenpark, waar de kotter op zee kan opladen na een periode ( 1 of 2 dagen) van vissen.

\section{Optimaliseren energiebalans}

Met het optimaliseren van de energiebalans wordt er gekeken hoe verschillende aspecten die nu alleen in een kotter gebundeld zitten om voor elk proces de energiebalans te optimaliseren. Het lokaliseren en detecteren van de vis wordt door autonome afstand bestuurbare onderzeeërs gedaan, een kotter kan op zee blijven en zich toespitsen op vissen vangen, gevangen vis wordt verwerkt en gekoeld op een speciaal aan een windmolenpark gekoppeld platvorm, transport van gevangen vis en crew wordt door gespecialiseerde schepen gedaan.

\section{Multi-use schepen}

Crew schepen voor onderhoudswerkzaamheden van windmolenparken liggen momenteel een deel van de dag te wachten tot de terugreis aanvaart wordt. Geopperd wordt om deze schepen te koppelen aan visserijactiviteiten met kooien en korven in windparken. Hierbij kan het schip nadat de crew afgezet is zich richten op het leeghalen van de viskooien en verwerken van de vis.

\section{Ronde 2}

De deelnemers door een brede verscheidenheid, van subsidie adviseurs tot beleidsmedewerkers RVO/LNV. Geen deelnemers met een visserij achtergrond.

\section{Bevindingen}

\section{Brandstofbesparing}

Waterstof is de komende jaren geen haalbare technologie, wel kan het 'Dual flex fuel - RCCI technologie' ingezet worden aldus een onderzoeker van TNO. Deze technologie heeft nu nog ongeveer 5 jaar ontwikkelingstermijn voordat het geschikt is voor commerciële toepassing. Hiermee kan een $10 \%$ reductie van brandstofverbruik gehaald worden. Opgemerkt wordt dat pulstechniek $50 \%$ van brandstofverbruik verminderd. De oude techniek (boomkor) weer oppakken en dan met veel techniek $10 \%$ brandstof besparen wordt als water naar de zee dragen ervaren.

\section{Benutten reststromen}

Energie reststromen van de hoofdmotor van een schip hergebruiken om vis te koelen, zit zou indien toegepast $20 \%$ kunnen besparen en energiegebruik koeling van een schip. 


\section{Visherkenning}

Voor visherkenning moet ingezet worden op licht en camera technologie voor soortherkenning en detectie. Ook moet er gekeken worden naar sonar en laser (flits) (LIDAR) technologische ontwikkeling. Koppelen ontwikkelingen aan laser gestuurde zalm fileer technologie (Marine Harvest) waarbij er met een laser naar visdikte, lengte ect gekeken wordt om een efficiënte fileersnede te maken.

\section{Vistechniek}

De toekomstige visserijtechniek moet zich richten op het aantrekken van vissen met bijvoorbeeld een lokvis, of aantrekken naar vistuig door gebruik te maken van feromonen / aas lokstoffen. Echter dient er veel ontwikkeling te moeten gebeuren op geurverspreiding door waterstroming of de effectiviteit van deze methode te verhogen. Een ander idee is om met gebruik geluidsgolven uit twee autonoom gestuurde submariene vis richting het pad van de kotter te jagen. Opgemerkt wordt dat de kotter zelf dan wel geluidsarm moet zijn.

\section{Multi-use schepen}

Vissen met een onderzeeër die zichzelf oplaadt op een oplaadpunt in een windpark. Vangst, vis en scheepsgegevens worden overdragen via wifi van het windpark.

\section{Boodschappen aan het OFL-traject Noordzee akkoord}

De deelnemers aan de COP-bijeenkomst werden uitgenodigd om boodschappen mee te geven aan het Overlegorgaan Fysieke Leefomgeving dat, onder leiding van de heer Wallage, op dit moment met alle betrokken partijen bezig is met het formuleren van een Noordzee Akkoord.

Vanuit de kenniswerksessies werden de volgende centrale boodschappen geformuleerd:

Sessie draagkracht, ronde 1: De beleidsontwikkelingen gaan nu zo snel dat ze "out of synch" zijn met de kennisbasis c.q. ontwikkeling van kennis, modellen en risicobeoordelingen die nodig zijn om de effecten van grootschalige ingrepen op het systeem te kunnen duiden c.q. goede afwegingen te kunnen maken voor medegebruik binnen de grenzen van het Noordzeesysteem.

Sessie draagkracht, ronde 2: Verbetering basisgegevens en ontsluiting: (a) verplichting om eigen gegevens uit monitoring van de offshore industrie publiek beschikbaar te maken, (b) samenwerking offshore industrie en kennisinstellingen rond monitoring; (c) Noordzeefonds inzetten voor monitoring.

De innovatiewerksessies hebben geen boodschap geformuleerd.

\section{Bijlage I: PowerPointpresentatie}
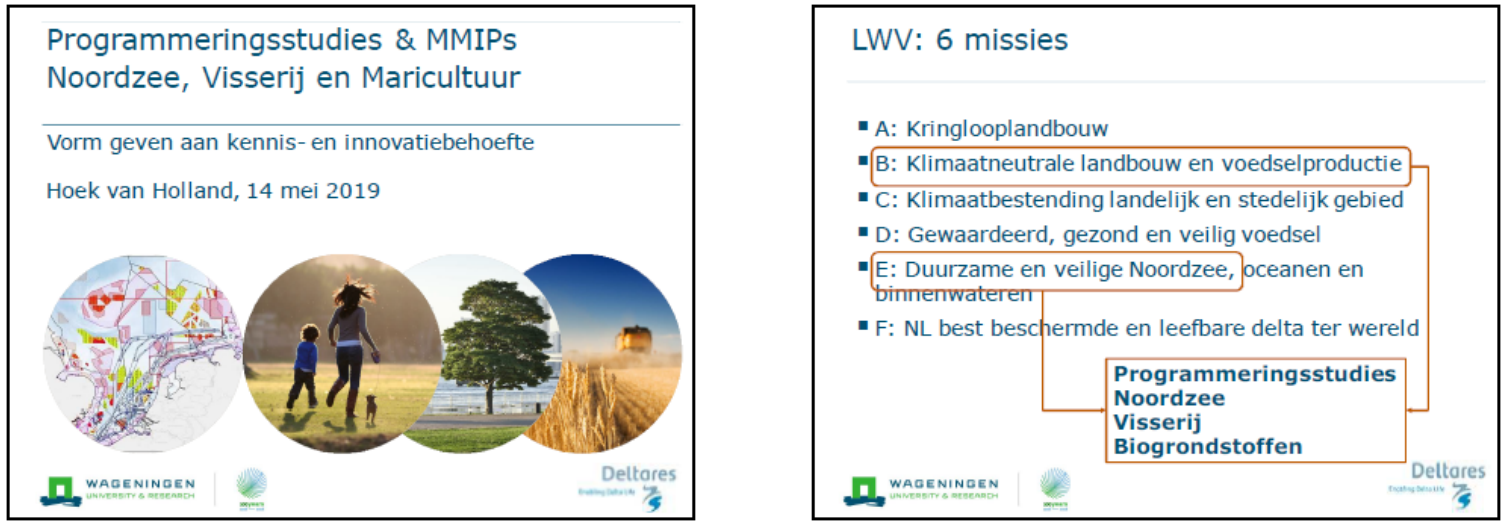


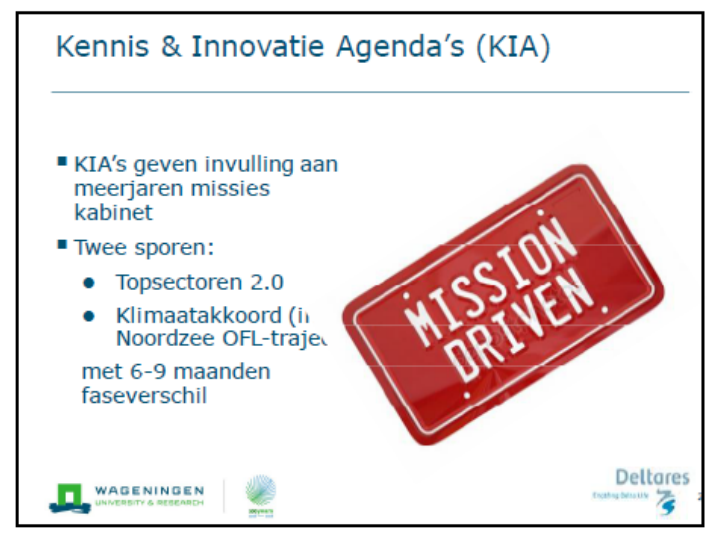

Aanpak programmeringsstudies \& MMIPs rond Noordzee, Visserij \& Biogrondstoffen

- Samenwerking 3 studies

- Analyse: Wat weten we wel, niet of gedeeltelijk?

- Workshop beleid en onderzoek

- Concept MMIPS opgeleverd

- Vandaag jullie input

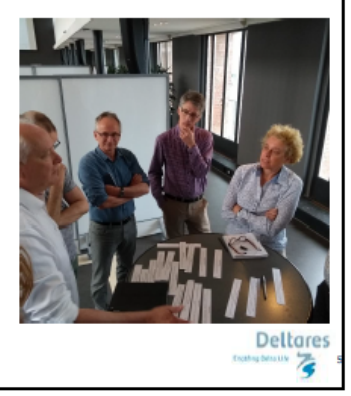

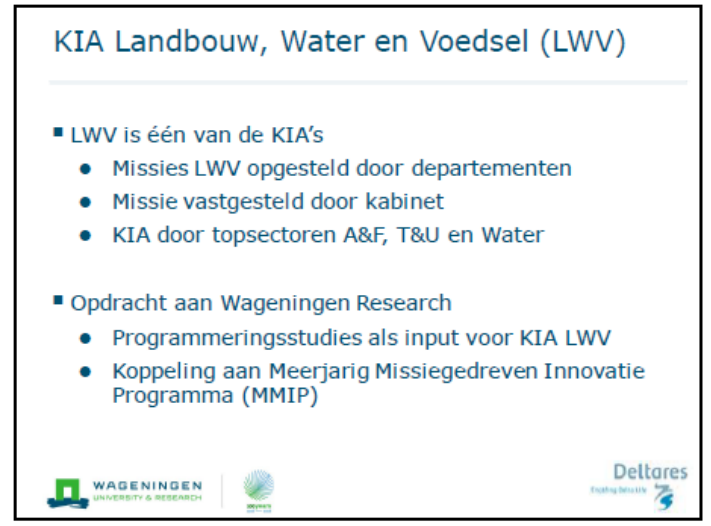

KIA prioriteiten* thema Noordzee**

${ }^{*}$ in willekeurige volgorde, ${ }^{* *}$ excl. visserij en maricultuur

- Monitoring, modellering, data- en informatiemanagement en afwegingskaders voor menselijk medegebruik binnen draagkracht ecosysteem

- Natuurvriendelijke aanleg grootschalige bouwwerken voor energieproductie en stimulering van natuur hierbinnen

- Meervoudig ruimtegebruik door combinaties van energie infrastructuur met voedselproductie

- Vermindering van afval in zee

D. WAGENINGEN Deltares

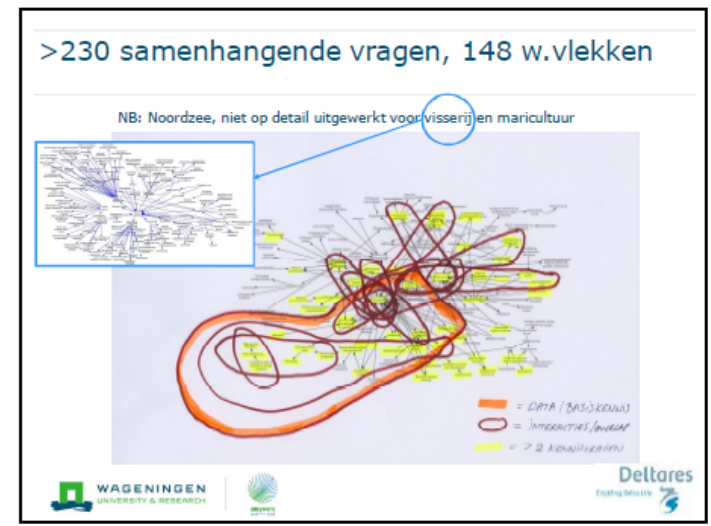

Aanbeveling uitvoering KIA

De versnipperde aansturing, programmering en financiering van de TO2-instellingen belemmert de samenwerking op de grote thema's die we nu juist gezamenlijk en integraal moeten gaan oppakken.

Oplossing = één gezamenlijke TO2-

kennisagenda voor de belangrijkste thema's uit de KIA LWV (en de andere KIA's met relatie tot Noordzee).

D. WAgEningen 2 Deltares

\begin{tabular}{l} 
KIA prioriteiten* thema Visserij \\
* in willekeurige volgorde \\
\hline - Versterken beheer visbestanden \\
- Verbetering selectiviteit \\
- Vermindering bodemberoering \\
- Vermindering emissies \\
- Verbetering arbeidsomstandigheden \\
- Verbetering dierenwelzijn \\
- Verbeteren van economisch perspectief \\
- Systeemveranderingen \\
D. WAaENINaEN
\end{tabular}

Jullie input gevraagd!
3. Samen werken aan
concrete kennis- of
innovatie casus
2. Concept-MmiPs: jullie
prioriteiten stickeren
1. Burengesprek
Maar eerst: zijn er
brandende vragen?




\begin{tabular}{|c|c|c|}
\hline \multicolumn{3}{|c|}{$\begin{array}{l}\text { KIA prioriteiten* thema Zeewier } \\
* \text { in willekeurige volgorde }\end{array}$} \\
\hline $\begin{array}{l}\text { - Technische h } \\
\text { - Ruimtelijke ir } \\
\text { - Ecologische h } \\
\text { - Ontw. duurza } \\
\text { circulair mak } \\
\text { - Fysiologie en } \\
\text { - Verwerking o } \\
\text { - Economische } \\
\text { - Bestuurlijke }\end{array}$ & $\begin{array}{l}\text { baart } \\
\text { ssing } \\
\text { Ibaar } \\
\text { e teel } \\
\text { redel } \\
\text { st: op } \\
\text { alba } \\
\text { ecter }\end{array}$ & $\begin{array}{l}\text { logistiek } \\
\text { o-impact } \\
\text { lagen, } \\
\text { ingstechn. } \\
\text { cases }\end{array}$ \\
\hline D. WAGENINGEN & $\underline{2}$ & Deltares \\
\hline
\end{tabular}

\section{KIA prioriteiten* thema Zeewier}

- Technische haalbaarheid: ontw. offshore hardware en logistiek

- Ecologische haalbaarheid: draagkracht Noordzee, eco-impact

Ontw. duurzame teeltwijzen: beheersen ziekten en plagen,

- Verwerking oogst: opslag, transport, ontw. fractioneringstechn.

- Economische haalbaarheid: ontw. afzet en business cases

D. WAGENINGEN

\section{Burengesprek}

- Praat 5 minuten met je buurman over deze vraag:

Als jullie een subsidie van $2 \mathrm{mln}$ euro zouden krijgen voor het beantwoorden van één

kennisvraag of voor het uitvoeren van één

innovatieproject op de Noordzee, waar

zouden jullie dat geld dan aan uitgeven?

- Schrijf je antwoord op het kaartje

D. WAGENINGEN

\section{Input concept-MMIPs}

- Iedereen krijgt bij verlaten van de zaal 6 stickers

- Plak op de posters van de 3 MMIPs (Noordzee, Visserij en Zeewier), sticker bij onderwerp dat volgens jouwprioriteit heeft

Opdracht middagsessie wordt na lunch uitgelegd.

D. WAGENINGEN Deltores

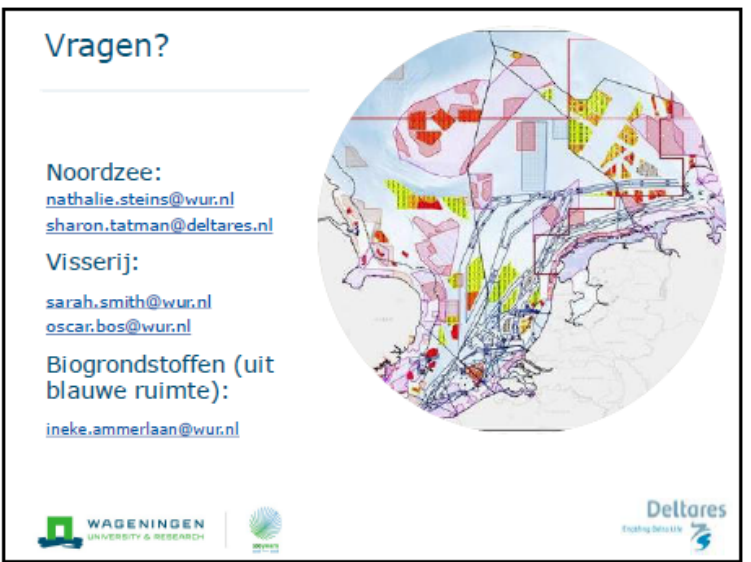




\section{Bijlage 5 Financieringsmogelijkheden}

De digitale versie van de originele PowerPoint is ter beschikking gesteld aan de opdrachtgever.

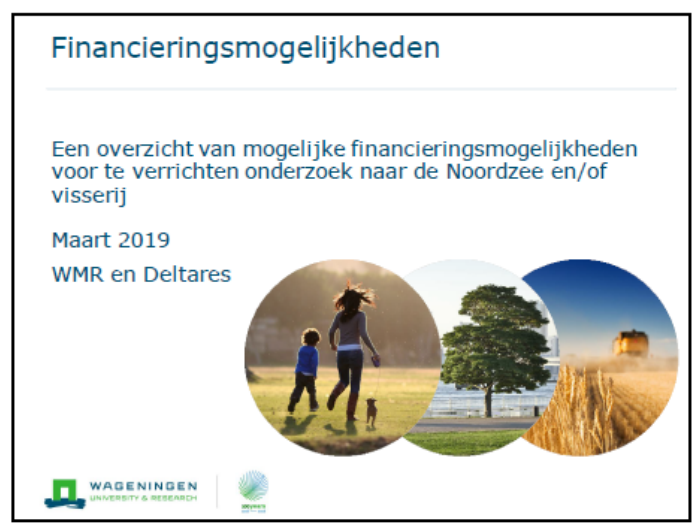

TO2 | Deltares
- TO2-instituut
- Onafhankelijk toegepast kennisinstituut op het gebied van
water en ondergrond dat wereldwijd werkt aan slimme
innovaties, oplossingen en toepassingen voor mens, milieu en
maatschappij in delta's, kustregio's en riviergebieden
- Instituutsfinanciering: Strategisch Onderzoek (SO)
programmering
- Programmafinanciering: Kennis voor Primaire Processen (KPP)
programma via ministerie van I\&W

Inleiding

De financiering voor TO2- en NWO-instituten verschilt wezenlijk van elkaar. De Nederlandse instituten met betrekking tot marien onderzoek:

- TO2-instituten

- Wageningen Marine Research

- Deltares

- MARIN

- TNO

- NWO-instituten

- NIOZ

D. WAGENINGEN

\section{TO2 | Extra bestedingsmiddelen}

- Versterken kennisbasis: vanaf 2018 structureel extra middelen vanuit ministerie voor versterken kennisbasis gedurende huidige regeerakkoord: $€ 42 \mathrm{mln}$

- Missiegedreven kennis- en innovatieprogramma's: $€ 33 \mathrm{mln}$ vanaf 2020

D. WAGENINGEN
TO2 | Wageningen Marine Research

- TO2-instituut

- Levert met kennis, onafhankelijk wetenschappelijk onderzoek en advies een wezenlijke bijdrage aan een duurzamer, zorgvuldiger beheer, gebruik en bescherming van de
natuurlijke rijkdommen in zee-, kust- en zoetwatergebieden

- Instituutsfinanciering: Kennisbasis programmering (KB) vanuit ministerie van LNV

- Programmafinanciering: Beleidsondersteunend onderzoek (BO) via ministerie van LNV

1. WAGENINGEN
NWO | NIOZ

- NWO-instituut

- Fundamenteel onderzoek naar oceanen en Noordzee

- Basisfinanciering vanuit NWO

1. WAGENINGen 


\section{Subsidies | hoofdcategorieën}

De subsidies zijn onderverdeeld in 5 categorieën:

- NWO

- EU

- Topsector

- Ministeries

- Overig

D. WAGENINGEN
NWO | Nationale Wetenschapsagenda

- RKI's, HBO-en TO2-instituten kunnen nu ook mee doen

- Jaarlijkse open calls + PPS3 calls

- Niet meer dan $20 \%$ van NWO-middelen naar toegepast onderzoek

- Subsidiepercentage: minimaal $10 \%$ van totale budget moet cofinanciering zijn. Grotendeels door I\&W en LNV.

D. WAGENINGEN

\section{NWO | Algemeen}

- In principe alleen aio's en post-docs

- Betalen alleen aan universiteiten en kennisinstellingen met eerste geldstroom (zoals NIOZ, dus TO2 kunnen vaak niet rechtstreeks aanvrager zijn)

- Heel uiteenlopende programma's, zowel op inhoud als op financieringsmodel

- Meestal ongunstig voor TO2-instituten. Als onderaannemer zou financieel gezien wel gunstig kunnen zijn. Enkele nadelen:

- Geen invloed tijdens opstellen projectplan

- Bij groot bedrag vindt er aanbesteding plaats waardoor

het niet zeker is dat je onderaannemer wordt

- EU wil geen onderaannemers bij grote bedragen, dan dien je partner te zijn

D. WAGENINGEN

\section{NWO | bijdrage 'Cross-over programma'}

- NWO financiert onderzoek in publiek- private samenwerking (PPS) dat gericht is op het bereiken van significante impuact op mazatschappelelije vitdagingen, waarbij de
onderzoeksthema's meerdere topsectoren verbinden

- Helft gefinancierd door partners, helft NWO

- Call voor grote en langdurige ( $\epsilon 10-20 \mathrm{mln} ; 5-10 \mathrm{jaar})$

- Minimaal 3 topsectoren betrokken

- $30 \%$ (in onderhandeling) externe matching, waarvan minimaal $10 \%$ in cash van private

- Ministeries kunnen proberen aan te haken met hun kennisagenda's

- Drietal onderwerpen:

- De ecologische effecten van windparken op zee

- Meervoudig ruimtegebruik en manieren om windparken op natuur-mitigerende en

indusieve wijze te bouwen

- Inzicht in het ecologische systeem van de Noordzee

D. WAGENINGEN

\section{NWO | Visserij innovatiefonds}

- Innovatiegeld voor visserijsector

- In beginfase, dus nog weinig over bekend (matchmaking day in april zal hierover gaan)

- $€ 15 \mathrm{mln}$

- NWO geeft aan dat het ook voor TO2 interessant is

\section{WAGENINGEN}

NWO | ORC 2019

- Financiering van onderzoek en innovatie gericht op de routes van de NWA (blauwe door interdisciplinaire, kennisketenbrede consortia, waarin ook relevante

maatschappelijke partners vertegenwoordigd zijn,

Onderzoekers van verschillende instellingen kunnen als penvoerder namens het
consortium optreden. Daarnaast bestaat het consortium uit partners die het project in consortium optreden. Daarnaast bestaat het consortium u $u$ pe

- Het budget dat kan worden aangevraagd kent verschillende bandbreedtes

- EUR 0,5 tot 2 miljoen

- EUR 2 tot 5 miljoen

- Elke aanvraag dient $10 \%$ eigen bijdrage in te brengen

1. WAGENINGEN 


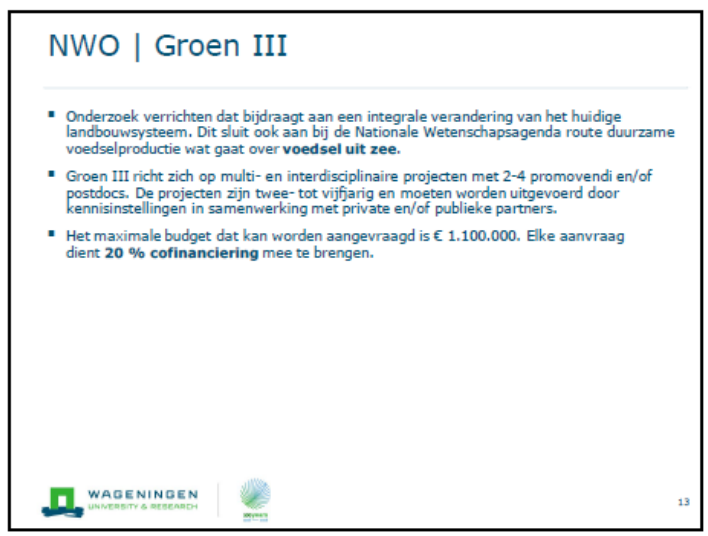

\section{EU | Algemeen}

- Heel uiteenlopende programma's

- Verschillende subisieregelingen

D. WAGENINGEN

\section{$+2$}

\section{EU | Eurostars 2}

- Totale Nederlandse budget: $€ 19 \mathrm{mln}$

- Projectcoôrdinator en uitvoerder is onderzoekuitvoerende mkb uit een Eurostars land

- Subsidie:

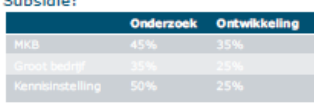

- Maximaal $€ 500.000$ per project voor Nederlandse partijen

- Minimaal 2 Eurostarslander

- Grote concurrentie

D. WAGENINGEN
EU | Europees Fonds voor Regionale Ontwikkeling (EFRO)

- 4 regio's

- Zuid (OP-Zuid)

- Noord (OP-Noord)

- West (OP-West)

- Oost (OP-Oost)

- Penvoeder: moet meestal MKB bedrijf zijn

- Tijdverantwoording: is nodig

- Subsidiepercentage: maximaal 50\%. Dus minimaal 50\% nationale cofinanciering vereist en deze kan worden opgebracht door de Rijksoverheid, decentrale

D.w

GENINGEN

EU | Europees Fonds voor

Regionale Ontwikkeling (EFRO)

- OP-Zuid biedt subsidiemogelijkheden voor.

- Versterken en verbreden van het Zuid-Nederlandse innovatiesysteem door het stimuleren van cross-overs tussende internationale topclusters onderling en tussen de hiermee beter aan kan haken op de kennis die wordt ontwikkeld

- Stimulering van open innovatie en methoden en processen die daarbij aansluiten, zoals
living labs, proeftuinen, co-creatie, sociale innovatie en het benutten van design

- Bevordering van samenwerking tussen (MKB)bedriven onderling en tussen

- Betere aansluiting van het onderwijs op de arbeidsvraag naar technisch geschoolde

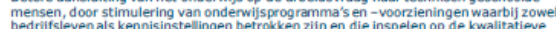
is en die het bedriftsleven in de topclusters stelt aan technisch talent. kwalitatiev

- Vernieuwing in technieken, producten, processen en diensten op het vlak van duurzame
energieproductie en energie-efficientie.

- Slimme uitrol van nieuwe technieken in de bebouwde omgeving.

WAGENINGEN

EU | Europees Fonds voor

Regionale Ontwikkeling (EFRO)

- OP-Noord biedt subsidiemogelijkheden voor:

- Projecten rondom:

- Human capital, kennis en innovatie - Koolstofarme economie

- $\epsilon 103,5 \mathrm{mln}$ van Europa, $€ 18,5 \mathrm{mln}$ door het Rijk

- Het OP-Noord programma biedt voornamelijk kansen voor het mkb, maar ook

Then 

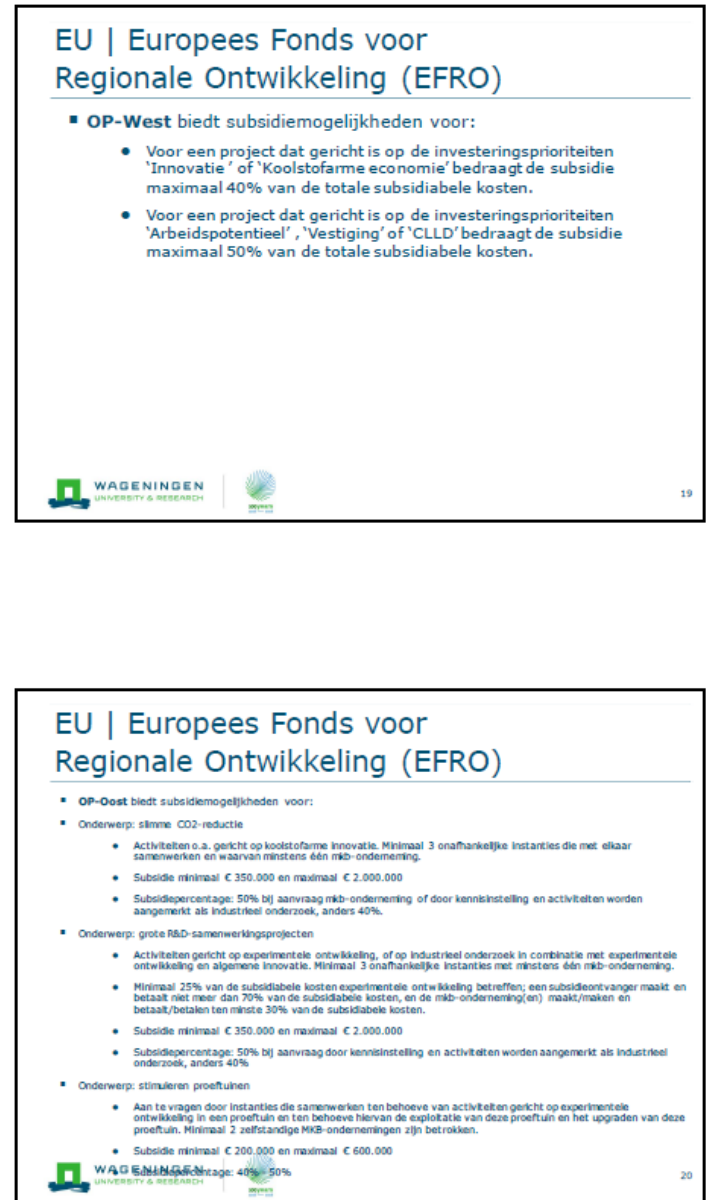

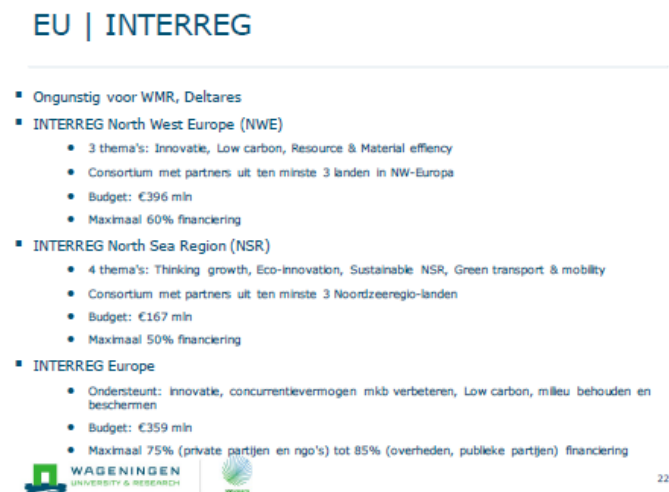

\section{EU | BANOS}

- Europees geld dat via NWO verdeeld wordt

- Aantrekkelijk voor NIOZ (en universiteiten)

- Onaantrekkelijk WMR en Deltares

- Vooral voor langetermijn onderzoeken

- 6 jaar lopend EU-programma voor Oost- en Noordzee: start 2020 of 2021

- Budget: $€ 2.500 .000$

- Nederland 6 mln: 5 mln NWO en 1 mln ministerie I\&W - Subsidiepercentage bepaald door NWO

WAGENINGEN

\section{EU | H2020 en Horizon Europe}

- Horizon Europa: vanaf 1 januari 2021

- Budgetvoorstel: $€ 100$ miljard

- Subsidiepercentage:

- personele lasten $100 \%$ vergoed

- indirecte kosten $25 \%$ vergoed

- Niet alle kosten komen voor vergoeding in aanmerking

- Ongunstig voor WMR en Deltares (35-45\% eigen geld) en langdurende projecten 


\section{EU | Life}

- Vanuit DG Environment. Twee subprogramma's:

\section{- Environment}

- Climate action

- Subsidiepercentage: $30-70 \%$

WAGENINGEN

EU | Tenders en FWC (Framework contract)

- EU: tenders, ook voor raamwerkcontracten

- Veel werk om tender te schrijven

- Grote concurrentie met consultants o.b.v. kwaliteit/geld

D. WAGENINGEN

EU | EU-Cost
- Wetenschappers worden uitgenodigd om bij elkaar te komen
zodat kennis gedeeld kan worden en gekeken kan worden
waar nog kennisgaten zitten. Vaak als voorbereiding op H2020
calls. Uren worden niet vergoed maar reis- en vergaderkosten
wel.

\section{Topsectoren | Algemeen}

- Publiek-Private Samenwerkingsverbanden (PPS-en)

- Bedrijfsleven geld

- EZ DLO-subsidie

- TKI-toeslag subsidie

- PPS: $\min € 2 \mathrm{mln}$ subsidiabele projectkosten, project

max 10 jaar, min $30 \%$ private financiering van de

projectkosten: in cash of in natura

- Maximale steunintensiteit:

- Voor fundamenteel onderzoek: $100 \%$

- Voor industrieel onderzoek: $50 \%$

- Voor experimentele ontwikkeling: $25 \%$ van de subsidiabele kosten.

D. WAGENINGEN

\section{Topsectoren | Open calls}

- Zoals bij de Topsectoren Energie en Agro \& Food

D. WAGENINGEN

- Alle marktpartijen leggen gelijkwaardig deel van budget in

- Voor TKI voorstellen via de kennisinstiuten (zoals bij de TKI's deltatechnologie en watertechnologie) zijn KIA's leidend 
Topsector | Gezamenlijke topsector call van NWO en TS Water en Maritiem

- Vier thema's van Blauwe Route

- Leven in de delta

- Water als bron

- Water als blauwe weg

- Leven op het water

- Private en publieke partners in het projectconsortium dienen gezamenlijk tenminste $20 \%$ van de projectkosten bij te dragen

- Maximaal 800k NWO-financiering per project

I. WAGENINGEN

Topsectoren | Water - subsector

Deltatechnologie

- Bedrijfsleven en kennisinstellingen voeren gezamenlijk PPSprojecten uit

- Financiering uit PPS-toeslag voor onderzoek en innovatie die EZK als bonus geeft op de cash bijdrage van het bedrijfsleven aan deze samenwerking

- Subsidiepercentage verschilt per topsectoren en programma's

Ministeries | Missiegedreven programma Natuurrijke Noordzee

Het doel van het missiegedreven programma Natuurrijke Noordzee is om het gebruik va de ecologische en fysieke ruimte te beperken

- 3 hoofllijnen:

- Natuurfunctie versterken: Reduceren van negatieve effecten van gebruik van de zee en het herstellen en versterken van het natuurlijke systeem.

- Voedselfunctie versterken: Duurzaam vissen en het mogelijk maken van voedselkweek (aquaculturr) op zee.

- Kennisgedreven innovatie: het beter begrijpen, benutten en beschermen van de Noordzee en de delta's, zodat ook wereldwiid duurzaamheid, welzijn en welvaart vergroot kan worden

D. WAGENINGEN
Ministeries | Wind op

zee Ecologisch Programma (WOZEP)

- Looptijd 2016-2021 (verlengd tot 2023 met additionele middelen)

- Budget: $€ 15 \mathrm{mln}$

- EZK financiert

- RWS is opdrachtnemer

Ministeries | Eigen middelen LNV en I\&W

- Kennisprogramma Primaire Processen (KPP-programmering): RWS naar Deltares

- Specialistisch Advies Projecten (SPA's) voor Deltares

- Eigen middelen

- Budget: ca. $€ 2.4 \mathrm{mln}$

- Deel van budget voor toegepaste onderzoekfinanciering

1. WAGENINGEN

Ministeries (BuZa) | Fonds Duurzaam Water (FDW)

Doel: bijdragen aan inclusieve, groene groei door het verbeteren van waterzekerheid en waterveiligheid in ontwikkelingslanden via publiek private

- 3 thema's:

- Duurzame toegang tot schoon drinkwater en sanitatie (inclusief afval)

- Efficiēnt watergebruik met name in de landbouw

- Verbeterd stroomgebiedbeheer en veilige delta's

- Minimaal één publieke organisatie, één bedrijf en één NGO of kennisinstelling

- Subsidie: minimaal $€ 500.000$ en maximaal $€ 3.000 .000$

- Subsidiepercentage: maximaal 60-70\% (thema-afhankelijk)

- Onderwerpen misschien niet heel relevant voor Noordzee en voor WMR en

1. WAGENINGEN 


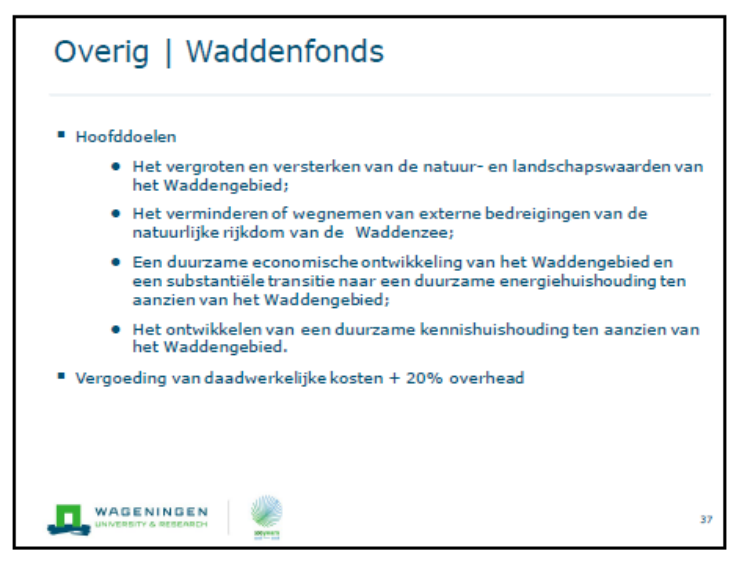

- Het vergroten en versterken van de natuur-en landschapswaarden van

natuurlijke rijkdom van de Waddenze aanzien van het Waddengebied

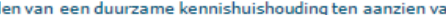

lijkekosten $+20 \%$ overtead

D. WAGENINGEN

Overig | RAAK
- Hoofddoelen
• Verbeteren kennisuitwisseling tussen hogescholen, het mkb, publieke
en kennisinstellingen en vergroten van het innovatief vermogen van
mkb-ondernemingen
- Aanvager dient door de overheid bekostigde hogeschool te zijn

Overig | Charitatieve fondsen

- Heel verschillend per fonds, zowel onderwerpen en financieringen. Goede relatie nodig met partij. Voor LNV niet relevant

- Voorbeelden

- Postcodeloterij

- Bill \& Melissa Gates Foundation

- OAK Foundation

- Packard Foundation

- LRF

- Adessium

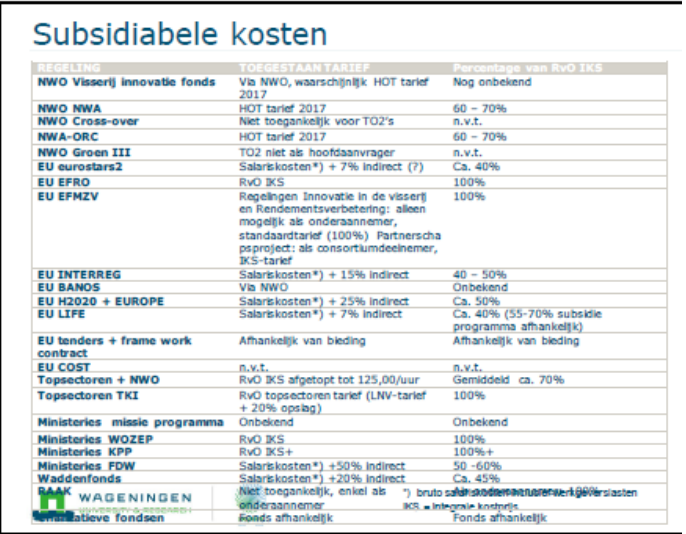




\section{Bijlage 6 Kennis- en innovatievragen Noordzee: Wind op Zee in relatie tot Ecosysteem, Natuur en Meervoudig Ruimtegebruik}

Overzicht van kennisvragen exclusief visserij over het onderwerp wind op zee en de relatie met het onderwerp ecosysteem.

\begin{tabular}{|c|c|c|}
\hline $\begin{array}{l}\text { Kennisvragen exclusief visserij over het onderwerp wind op zee en } \\
\text { de relatie met het onderwerp ecosysteem }\end{array}$ & $\begin{array}{l}\text { Kennis en/of } \\
\text { innovatie } \\
\text { opgave? }\end{array}$ & $\begin{array}{l}\text { Gedekt in } \\
\text { (afgewezen) NWA } \\
\text { Noordzee in } \\
\text { Transitie voorstel }\end{array}$ \\
\hline \multicolumn{3}{|l|}{ Gedeeltelijke witte vlek } \\
\hline \multicolumn{3}{|l|}{ Ecosysteem: Ecologische (randvoor)waarden } \\
\hline $\begin{array}{l}\text { Bij een grootschalige uitrol zal ook gekeken worden naar gebieden in de } \\
\text { Noordelijke Noordzee: zijn daar alle kwetsbare soorten in beeld, of zijn er } \\
\text { nieuwe soorten waarvoor de ecologische grenzen in beeld komen? }\end{array}$ & Kennis & $x$ \\
\hline $\begin{array}{l}\text { Kan een offshore windpark in een natuurgebied staan? Waar wel, en onder } \\
\text { welke voorwaarden, en waar is dat niet mogelijk? }\end{array}$ & Kennis & $x$ \\
\hline $\begin{array}{l}\text { Wat zijn de meest geschikte locaties voor offshore wind vanuit kosten, } \\
\text { onderhouds- en ruimtelijk perspectief (na 2030)? }\end{array}$ & Kennis & $x$ \\
\hline $\begin{array}{l}\text { Wat zijn vanuit ecologisch perspectief geschikte en ongeschikte locaties } \\
\text { voor offshore windparken (na 2030)? }\end{array}$ & Kennis & $\mathrm{x}$ \\
\hline \multicolumn{3}{|l|}{ Ecosysteem: Effect/impact/risico } \\
\hline $\begin{array}{l}\text { Wat zijn mogelijkheden voor systemen om getijde-, golfslag- en zonne- } \\
\text { energie te winnen buiten windparken? Welke factoren bepalen geschikte } \\
\text { locaties? }\end{array}$ & Kennis & $\mathrm{x}$ \\
\hline \multicolumn{3}{|l|}{ Ecosysteem: Natuurherstel } \\
\hline $\begin{array}{l}\text { Hoe kan natuurinclusief bouwen van met name offshore windparken, en } \\
\text { wellicht ook drijvende (onderbroken) eilanden, bijdragen aan herstel en } \\
\text { ontwikkeling van de Noordzeenatuur? }\end{array}$ & Kennis & $\mathrm{x}$ \\
\hline $\begin{array}{l}\text { Hoe kunnen kansen voor, en risico's van natuurinclusief bouwen } \\
\text { inzichtelijk worden gemaakt en op transparante wijze worden } \\
\text { geëvalueerd? }\end{array}$ & Kennis & \\
\hline \multicolumn{3}{|l|}{ Ecosysteem: Ja (algemeen) } \\
\hline $\begin{array}{l}\text { Verankering en scour protection als ecologisch 3D netwerk in een } \\
\text { windpark }\end{array}$ & Kennis & \\
\hline \multicolumn{3}{|l|}{ Volledige witte vlekvragen } \\
\hline \multicolumn{3}{|l|}{ Ecosysteem: Ecologische (randvoor)waarden } \\
\hline $\begin{array}{l}\text { Is er een reëel risico op een dusdanige verandering van biofysische } \\
\text { processen in de Noordzee dat er een omslagpunt of een onomkeerbare } \\
\text { situatie wordt bereikt? Is het aantoonbaar wanneer een dergelijk moment } \\
\text { in zicht komt? }\end{array}$ & Kennis & $\mathrm{x}$ \\
\hline $\begin{array}{l}\text { Voor welke soorten en levensgemeenschappen lopen we met de uitrol van } \\
\text { wind op zee tot } 2030 \text { tegen een grens aan? }\end{array}$ & Kennis & $\mathrm{x}$ \\
\hline $\begin{array}{l}\text { Wat is de draagkracht van de Noordzee voor de functie wind op zee? } \\
\text { Wanneer wordt het effect op windvelden limiterend? }\end{array}$ & Kennis & $\mathrm{x}$ \\
\hline \multicolumn{3}{|l|}{ Ecosysteem: Ecosysteemdiensten } \\
\hline $\begin{array}{l}\text { Hoe passen de (extra) kosten van het combineren van wind en natuur in } \\
\text { het totale verdienmodel voor offshore windparken? Kan er worden }\end{array}$ & Kennis & $x$ \\
\hline
\end{tabular}




\begin{tabular}{|c|c|c|}
\hline $\begin{array}{l}\text { Kennisvragen exclusief visserij over het onderwerp wind op zee en } \\
\text { de relatie met het onderwerp ecosysteem }\end{array}$ & $\begin{array}{l}\text { Kennis en/of } \\
\text { innovatie } \\
\text { opgave? }\end{array}$ & $\begin{array}{l}\text { Gedekt in } \\
\text { (afgewezen) NWA } \\
\text { Noordzee in } \\
\text { Transitie voorstel }\end{array}$ \\
\hline
\end{tabular}

aangegeven welke prijsverhogingen het gevolg zijn van natuurinclusief bouwen als kostenpost? Hoe kunnen deze kosten worden verhaald? Wat zijn de mogelijke baten van het combineren van wind en natuur? En hoe kunnen deze baten worden gestimuleerd?

\section{Ecosysteem: Effect/impact/risico}

Vergroot de grootschalige uitrol van wind op zee de uitwisseling tussen Kennis $X$ populaties inheemse soorten? En wat betekent opschaling voor de verspreiding van uitheemse soorten?

Wat is het effect van offshore windparken op de draagkracht van het ecologische systeem (primaire, secondaire en tertiaire productie)

Wat zijn de gevolgen van de opruimplicht die geldt voor offshore installaties voor de dan ontstane natuur? Wat betekent dit voor het beginsel van 'geen achteruitgang' in de KRM?

Wat zijn de gevolgen voor het ecosysteem en het hydromorfologische

Kennis

Kennis

$X$ systeem van de Noordzee van een grootschalige uitrol van Wind op zee? Hoe kunnen de positieve en/of negatieve effecten kwalitatief, dan wel kwantitatief en eventueel monetair gemaakt worden? En hoe kun deze informatie worden evalueren? Wat zijn kansrijke mitigerende maatregelen? En is mitigatie (kosten)effectief en efficiënt?

\section{Ecosysteem: Natuurherste}

Hoe kunnen beleidsmakers aan stakeholders prikkels (financieel of anderszins) geven om tot natuurinclusieve oplossingen te komen en bottom up initiatieven voor natuurinclusieve oplossingen te stimuleren.

Hoe kunnen financiële en andersoortige kosten en baten van

Kennis

$\mathrm{X}$ natuurinclusief bouwen inzichtelijk worden gemaakt voor besluitvorming? Welke compensatiemogelijkheden kunnen worden ontwikkeld voor de negatieve effecten van wind op zee?

Welke rol kan natuurinclusief bouwen spelen bij de versterking van de natuur en het compenseren van de negatieve effecten van wind op zee?

Wat zijn de kosten en baten van verschillende mogelijkheden?

\section{Overzicht van kennisvragen exclusief visserij over het onderwerp wind op zee en het onderwerp natuur.}

\begin{tabular}{|c|c|c|}
\hline $\begin{array}{l}\text { Kennisvragen exclusief visserij over het onderwerp wind op zee en het } \\
\text { onderwerp natuur }\end{array}$ & $\begin{array}{l}\text { Kennis } \\
\text { en/of } \\
\text { innovatie } \\
\text { opgave? }\end{array}$ & $\begin{array}{l}\text { Gedekt in } \\
\text { (afgewezen) } \\
\text { NWA Noordzee } \\
\text { in Transitie } \\
\text { voorstel }\end{array}$ \\
\hline \multicolumn{3}{|l|}{ Gedeeltelijke witte vlek } \\
\hline $\begin{array}{l}\text { Hoe kan natuurinclusief bouwen van met name offshore windparken, en } \\
\text { wellicht ook drijvende (onderbroken) eilanden, bijdragen aan herstel en } \\
\text { ontwikkeling van de Noordzeenatuur? }\end{array}$ & Kennis & $x$ \\
\hline $\begin{array}{l}\text { Kan een offshore windpark in een natuurgebied staan? Waar wel, en onder } \\
\text { welke voorwaarden, en waar is dat niet mogelijk? }\end{array}$ & Kennis & $x$ \\
\hline Verankering en scour protection als ecologisch 3D netwerk in een windpark & Kennis & \\
\hline
\end{tabular}




\begin{tabular}{|c|c|c|}
\hline $\begin{array}{l}\text { Kennisvragen exclusief visserij over het onderwerp wind op zee en het } \\
\text { onderwerp natuur }\end{array}$ & $\begin{array}{l}\text { Kennis } \\
\text { en/of } \\
\text { innovatie } \\
\text { opgave? }\end{array}$ & $\begin{array}{l}\text { Gedekt in } \\
\text { (afgewezen) } \\
\text { NWA Noordzee } \\
\text { in Transitie } \\
\text { voorstel }\end{array}$ \\
\hline $\begin{array}{l}\text { Wat zijn de meest geschikte locaties voor offshore wind vanuit kosten, } \\
\text { onderhouds- en ruimtelijk perspectief (na 2030)? }\end{array}$ & Kennis & $x$ \\
\hline $\begin{array}{l}\text { Wat zijn de mogelijkheden om oesterbroedjes op te kweken in vijvers alvorens } \\
\text { ze uit te zetten in windmolenparken? }\end{array}$ & Kennis & \\
\hline $\begin{array}{l}\text { Wat zijn vanuit ecologisch perspectief geschikte en ongeschikte locaties voor } \\
\text { offshore windparken (na 2030)? }\end{array}$ & Kennis & $x$ \\
\hline \multicolumn{3}{|l|}{ Volledige witte vlekvragen } \\
\hline $\begin{array}{l}\text { Hoe kunnen beleidsmakers aan stakeholders prikkels (financieel of anderszins) } \\
\text { geven om tot natuurinclusieve oplossingen te komen en bottom up initiatieven } \\
\text { voor natuurinclusieve oplossingen te stimuleren. }\end{array}$ & Kennis & $x$ \\
\hline $\begin{array}{l}\text { Hoe kunnen financiële en andersoortige kosten en baten van natuurinclusief } \\
\text { bouwen inzichtelijk worden gemaakt voor besluitvorming? }\end{array}$ & Kennis & $x$ \\
\hline $\begin{array}{l}\text { Hoe passen de (extra) kosten van het combineren van wind en natuur in het } \\
\text { totale verdienmodel voor offshore windparken? Kan er worden aangegeven } \\
\text { welke prijsverhogingen het gevolg zijn van natuurinclusief bouwen als } \\
\text { kostenpost? Hoe kunnen deze kosten worden verhaald? Wat zijn de mogelijke } \\
\text { baten van het combineren van wind en natuur? En hoe kunnen deze baten } \\
\text { worden gestimuleerd? }\end{array}$ & Kennis & $x$ \\
\hline $\begin{array}{l}\text { Is er een reëel risico op een dusdanige verandering van biofysische processen } \\
\text { in de Noordzee dat er een omslagpunt of een onomkeerbare situatie wordt } \\
\text { bereikt? Is het aantoonbaar wanneer een dergelijk moment in zicht komt? }\end{array}$ & Kennis & $x$ \\
\hline $\begin{array}{l}\text { Vergroot de grootschalige uitrol van wind op zee de uitwisseling tussen } \\
\text { populaties inheemse soorten? En wat betekent opschaling voor de verspreiding } \\
\text { van uitheemse soorten? }\end{array}$ & Kennis & $x$ \\
\hline $\begin{array}{l}\text { Voor welke soorten en levensgemeenschappen lopen we met de uitrol van } \\
\text { wind op zee tot } 2030 \text { tegen een grens aan? }\end{array}$ & Kennis & $x$ \\
\hline $\begin{array}{l}\text { Wat is de draagkracht van de Noordzee voor de functie wind op zee? Wanneer } \\
\text { wordt het effect op windvelden limiterend? }\end{array}$ & Kennis & $x$ \\
\hline $\begin{array}{l}\text { Wat is het effect van offshore windparken op de draagkracht van het } \\
\text { ecologische systeem (primaire, secondaire en tertiaire productie) }\end{array}$ & Kennis & $x$ \\
\hline $\begin{array}{l}\text { Wat zijn de gevolgen van de opruimplicht die geldt voor offshore installaties } \\
\text { voor de dan ontstane natuur? Wat betekent dit voor het beginsel van 'geen } \\
\text { achteruitgang' in de KRM? }\end{array}$ & Kennis & $x$ \\
\hline $\begin{array}{l}\text { Wat zijn de gevolgen voor het ecosysteem en het hydromorfologische systeem } \\
\text { van de Noordzee van een grootschalige uitrol van Wind op zee? Hoe kunnen } \\
\text { de positieve en/of negatieve effecten kwalitatief, dan wel kwantitatief en } \\
\text { eventueel monetair gemaakt worden? En hoe kun deze informatie worden } \\
\text { evalueren? Wat zijn kansrijke mitigerende maatregelen? En is mitigatie } \\
\text { (kosten)effectief en efficiënt? }\end{array}$ & Kennis & $x$ \\
\hline $\begin{array}{l}\text { Welke compensatiemogelijkheden kunnen worden ontwikkeld voor de } \\
\text { negatieve effecten van wind op zee? }\end{array}$ & Kennis & $x$ \\
\hline $\begin{array}{l}\text { Welke rol kan natuurinclusief bouwen spelen bij de versterking van de natuur } \\
\text { en het compenseren van de negatieve effecten van wind op zee? Wat zijn de } \\
\text { kosten en baten van verschillende mogelijkheden? }\end{array}$ & Kennis & $x$ \\
\hline
\end{tabular}




\section{Overzicht van kennisvragen exclusief visserij over het onderwerp wind op zee en het onderwerp medegebruik}

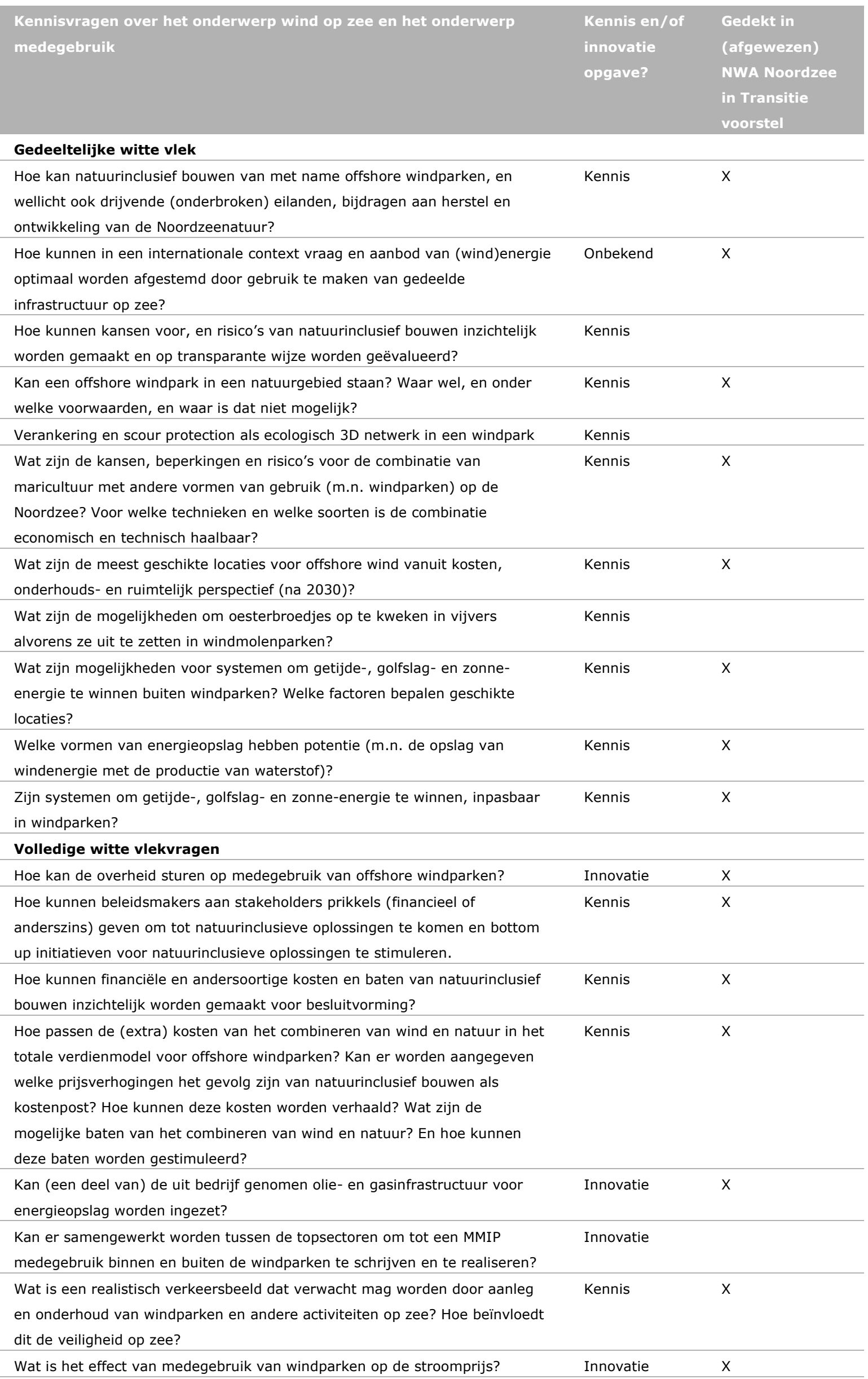




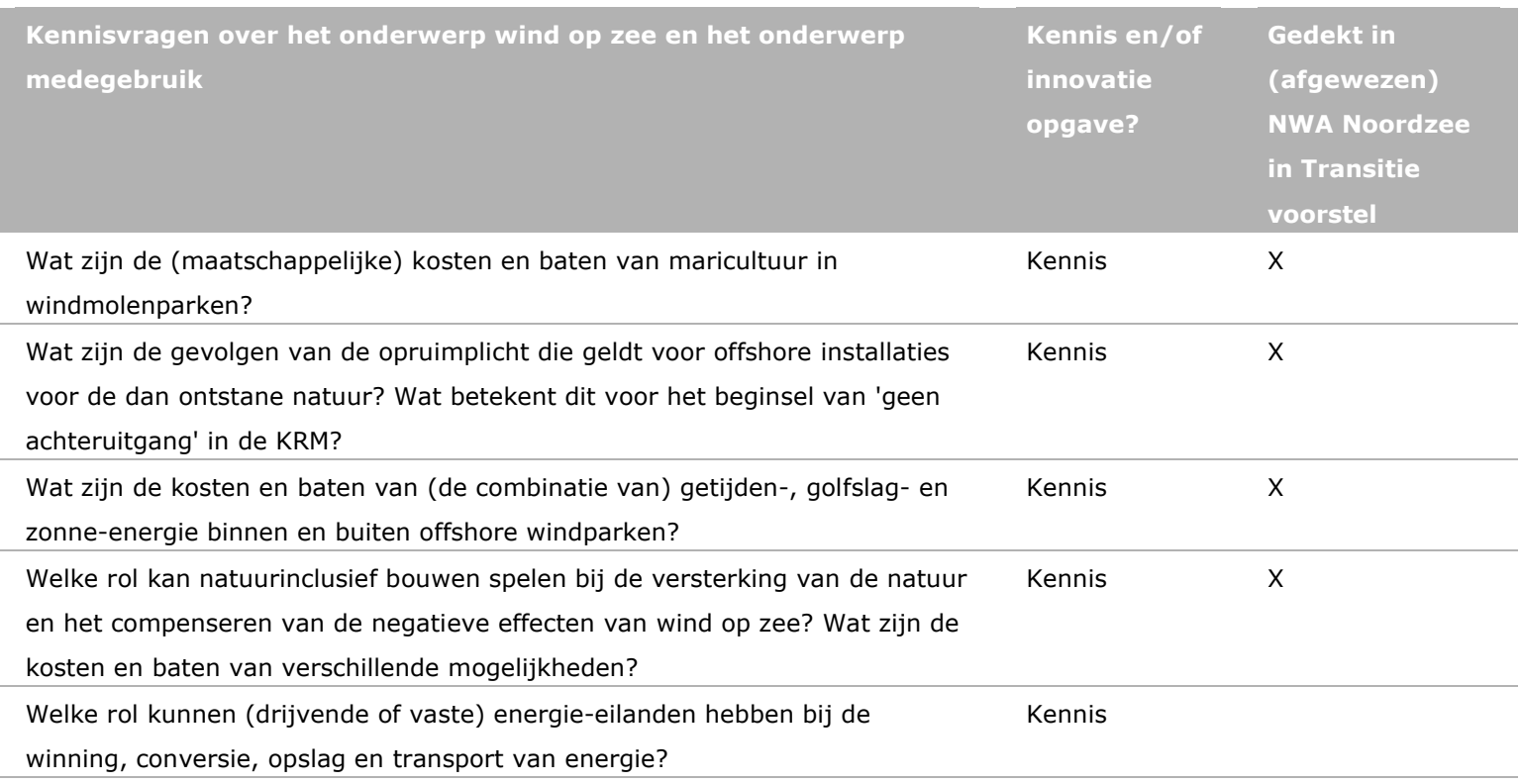

\section{Overzicht van kennisvragen exclusief visserij over het onderwerp wind op zee en het onderwerp natuur}

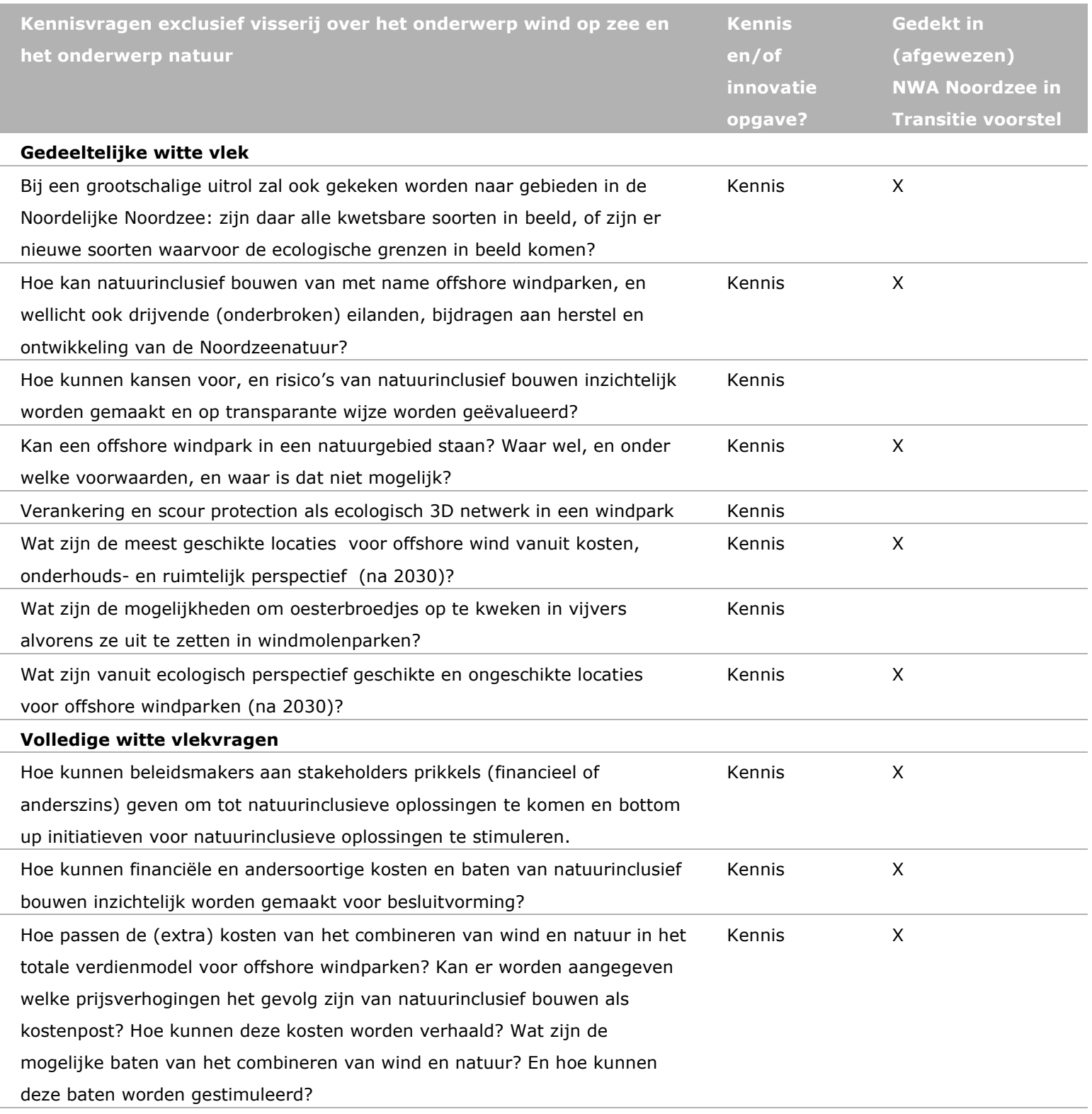


Kennisvragen exclusief visserij over het onderwerp wind op zee en

Is er een reëel risico op een dusdanige verandering van biofysische

Kennis

processen in de Noordzee dat er een omslagpunt of een onomkeerbare

situatie wordt bereikt? Is het aantoonbaar wanneer een dergelijk moment in zicht komt?

Vergroot de grootschalige uitrol van wind op zee de uitwisseling tussen

Kennis

$x$

populaties inheemse soorten? En wat betekent opschaling voor de

verspreiding van uitheemse soorten?

Voor welke soorten en levensgemeenschappen lopen we met de uitrol van

Kennis

$x$

wind op zee tot 2030 tegen een grens aan?

Wat is de draagkracht van de Noordzee voor de functie wind op zee?

Kennis

$\mathrm{x}$

Wanneer wordt het effect op windvelden limiterend?

Wat is het effect van offshore windparken op de draagkracht van het

Kennis

X

ecologische systeem (primaire, secondaire en tertiaire productie)

Wat zijn de gevolgen van de opruimplicht die geldt voor offshore installaties

voor de dan ontstane natuur? Wat betekent dit voor het beginsel van 'geen achteruitgang' in de KRM?

Wat zijn de gevolgen voor het ecosysteem en het hydromorfologische systeem van de Noordzee van een grootschalige uitrol van Wind op zee? Hoe kunnen de positieve en/of negatieve effecten kwalitatief, dan wel kwantitatief en eventueel monetair gemaakt worden? En hoe kun deze informatie worden evalueren? Wat zijn kansrijke mitigerende maatregelen? En is mitigatie (kosten)effectief en efficiënt?

Welke compensatiemogelijkheden kunnen worden ontwikkeld voor de negatieve effecten van wind op zee?

Welke rol kan natuurinclusief bouwen spelen bij de versterking van de

Kennis

Kennis $\quad x$

natuur en het compenseren van de negatieve effecten van wind op zee?

Kennis

Wat zijn de kosten en baten van verschillende mogelijkheden?

\section{Overzicht van kennisvragen exclusief visserij over het onderwerp wind op zee en het onderwerp medegebruik.}

\begin{tabular}{|c|c|c|}
\hline $\begin{array}{l}\text { Kennisvragen exclusief visserij over het onderwerp wind op zee en } \\
\text { het onderwerp medegebruik }\end{array}$ & $\begin{array}{l}\text { Kennis en/of } \\
\text { innovatie } \\
\text { opgave? }\end{array}$ & $\begin{array}{l}\text { Gedekt in } \\
\text { (afgewezen) } \\
\text { NWA Noordzee } \\
\text { in Transitie } \\
\text { voorstel }\end{array}$ \\
\hline \multicolumn{3}{|l|}{ Gedeeltelijke witte vlek } \\
\hline $\begin{array}{l}\text { Hoe kunnen in een internationale context vraag en aanbod van } \\
\text { (wind)energie optimaal worden afgestemd door gebruik te maken van } \\
\text { gedeelde infrastructuur op zee? }\end{array}$ & Onbekend & $\mathrm{x}$ \\
\hline $\begin{array}{l}\text { Kan een offshore windpark in een natuurgebied staan? Waar wel, en onder } \\
\text { welke voorwaarden, en waar is dat niet mogelijk? }\end{array}$ & Kennis & $\mathrm{x}$ \\
\hline Verankering en scour protection als ecologisch 3D netwerk in een windpark & Kennis & \\
\hline $\begin{array}{l}\text { Wat zijn de kansen, beperkingen en risico's voor de combinatie van } \\
\text { maricultuur met andere vormen van gebruik (m.n. windparken) op de }\end{array}$ & Kennis & $x$ \\
\hline
\end{tabular}


Noordzee? Voor welke technieken en welke soorten is de combinatie economisch en technisch haalbaar?

Wat zijn de meest geschikte locaties voor offshore wind vanuit kosten onderhouds- en ruimtelijk perspectief (na 2030)?

Wat zijn de mogelijkheden om oesterbroedjes op te kweken in vijvers alvorens ze uit te zetten in windmolenparken?

Wat zijn mogelijkheden voor systemen om getijde-, golfslag- en zonneenergie te winnen buiten windparken? Welke factoren bepalen geschikte locaties?

Welke vormen van energieopslag hebben potentie (m.n. de opslag van windenergie met de productie van waterstof)?

Zijn systemen om getijde-, golfslag- en zonne-energie te winnen, inpasbaar in windparken?

\section{Volledige witte vlekvragen}

Hoe kan de overheid sturen op medegebruik van offshore windparken? Hoe kunnen beleidsmakers aan stakeholders prikkels (financieel of anderszins) geven om tot natuurinclusieve oplossingen te komen en bottom up initiatieven voor natuurinclusieve oplossingen te stimuleren.

Hoe kunnen financiële en andersoortige kosten en baten van ning? natuurinclusief bouwen inzichtelijk worden gemaakt voor besluitvorming? Hoe passen de (extra) kosten van het combineren van wind en natuur in het totale verdienmodel voor offshore windparken? Kan er worden aangegeven welke prijsverhogingen het gevolg zijn van natuurinclusief bouwen als kostenpost? Hoe kunnen deze kosten worden verhaald? Wat zijn de mogelijke baten van het combineren van wind en natuur? En hoe kunnen deze baten worden gestimuleerd?

Kan (een deel van) de uit bedrijf genomen olie- en gasinfrastructuur voor energieopslag worden ingezet?

Kan er samengewerkt worden tussen de topsectoren om tot een MMIP medegebruik binnen en buiten de windparken te schrijven en te realiseren?

\begin{tabular}{|c|c|c|}
\hline $\begin{array}{l}\text { Wat is een realistisch verkeersbeeld dat verwacht mag worden door aanleg } \\
\text { en onderhoud van windparken en andere activiteiten op zee? Hoe } \\
\text { beïnvloedt dit de veiligheid op zee? }\end{array}$ & Kennis & $\mathrm{x}$ \\
\hline Wat is het effect van medegebruik van windparken op de stroomprijs? & Innovatie & $\mathrm{x}$ \\
\hline $\begin{array}{l}\text { Wat zijn de (maatschappelijke) kosten en baten van maricultuur in } \\
\text { windmolenparken? }\end{array}$ & Kennis & $x$ \\
\hline $\begin{array}{l}\text { Wat zijn de gevolgen van de opruimplicht die geldt voor offshore } \\
\text { installaties voor de dan ontstane natuur? Wat betekent dit voor het } \\
\text { beginsel van 'geen achteruitgang' in de KRM? }\end{array}$ & Kennis & $x$ \\
\hline $\begin{array}{l}\text { Wat zijn de kosten en baten van (de combinatie van) getijden-, golfslag- } \\
\text { en zonne-energie binnen en buiten offshore windparken? }\end{array}$ & Kennis & $\mathrm{x}$ \\
\hline $\begin{array}{l}\text { Welke rol kan natuurinclusief bouwen spelen bij de versterking van de } \\
\text { natuur en het compenseren van de negatieve effecten van wind op zee? } \\
\text { Wat zijn de kosten en baten van verschillende mogelijkheden? }\end{array}$ & Kennis & $\mathrm{x}$ \\
\hline $\begin{array}{l}\text { Welke rol kunnen (drijvende of vaste) energie-eilanden hebben bij de } \\
\text { winning, conversie, opslag en transport van energie? }\end{array}$ & Kennis & \\
\hline
\end{tabular}
winning, conversie, opslag en transport van energie? 


\section{Bijlage 7 Kennis- en innovatievragen Energie (anders dan wind) in relatie tot Ecosysteem, Natuur en Meervoudig Ruimtegebruik}

Overzicht kennisvragen exclusief visserij over het onderwerp energie (anders dan wind) en het onderwerp ecosysteem.

\begin{tabular}{|c|c|c|}
\hline $\begin{array}{l}\text { Kennisvraag exclusie visserij over het onderwerp energie } \\
\text { (anders dan wind) en het onderwerp ecosysteem }\end{array}$ & $\begin{array}{l}\text { Kennis en/of } \\
\text { innovatie } \\
\text { opgave? }\end{array}$ & $\begin{array}{l}\text { NWA Noordzee in } \\
\text { Transitie voorstel }\end{array}$ \\
\hline \multicolumn{3}{|l|}{ Gedeeltelijke witte vlekvragen } \\
\hline \multicolumn{3}{|l|}{ Ecosysteem: Effect/impact/risico } \\
\hline $\begin{array}{l}\text { Wat zijn de milieueffecten van de technieken waarmee getijde-, } \\
\text { golfslag- en zonne-energie kunnen worden opgewekt? }\end{array}$ & Kennis & $x$ \\
\hline $\begin{array}{l}\text { Wat zijn mogelijkheden voor systemen om getijde-, golfslag- en zonne- } \\
\text { energie te winnen buiten windparken? Welke factoren bepalen } \\
\text { geschikte locaties? }\end{array}$ & Kennis & $x$ \\
\hline \multicolumn{3}{|l|}{ Ecosysteem: Natuurherstel } \\
\hline \multicolumn{3}{|l|}{ Volledige witte vlekvragen } \\
\hline \multicolumn{3}{|l|}{ Ecosysteem: Effect/impact/risico } \\
\hline $\begin{array}{l}\text { Kan (een deel van) de olie- en gasinfrastructuur worden behouden om } \\
\text { (tijdelijk) te gebruiken voor CO2-opslag? }\end{array}$ & Kennis & $x$ \\
\hline $\begin{array}{l}\text { Wat is de potentie voor de winning van getijden-, golfslag- en zonne- } \\
\text { energie op de Noordzee? Welke technieken zijn hiervoor geschikt en } \\
\text { wat is hiervan de Technology Readiness Level (TRL)? }\end{array}$ & Kennis & $x$ \\
\hline \multicolumn{3}{|l|}{ Ecosysteem: Natuurherstel } \\
\hline $\begin{array}{l}\text { Hoe kunnen beleidsmakers aan stakeholders prikkels (financieel of } \\
\text { anderszins) geven om tot natuurinclusieve oplossingen te komen en } \\
\text { bottom up initiatieven voor natuurinclusieve oplossingen te stimuleren. }\end{array}$ & Kennis & $x$ \\
\hline
\end{tabular}


Overzicht kennisvragen exclusief visserij over het onderwerp energie (anders dan wind) en de relatie met het onderwerp natuur.

Kennisvragen exclusief visserij over het onderwerp energie

Kennis en/of

NWA Noordzee in

(anders dan wind) en de relatie met het onderwerp natuur

\section{Gedeeltelijke witte vlek}

Hoe kan natuurinclusief bouwen van met name offshore windparken, en opgave?

wellicht ook drijvende (onderbroken) eilanden, bijdragen aan herstel en ontwikkeling van de Noordzeenatuur?

\section{Volledige witte vlek}

Hoe kunnen beleidsmakers aan stakeholders prikkels (financieel of

Kennis

$X$

anderszins) geven om tot natuurinclusieve oplossingen te komen en

bottom up initiatieven voor natuurinclusieve oplossingen te stimuleren.

Wat zijn de gevolgen van de opruimplicht die geldt voor offshore

Kennis

$X$ installaties voor de dan ontstane natuur? Wat betekent dit voor het

beginsel van 'geen achteruitgang' in de KRM?

Wat zijn de kansen voor leefgemeenschappen (habitats) en soorten met Kennis

het oog op de ontwikkeling van eilanden in zee?

Welke risico's en kansen kunnen voortkomen uit opslag van $\mathrm{CO} 2$ op de Kennis

Noordzee?

Overzicht kennisvragen exclusief visserij over het onderwerp energie (anders dan wind) en het onderwerp medegebruik.

\begin{tabular}{|c|c|c|}
\hline $\begin{array}{l}\text { Kennisvragen exclusief visserij over het onderwerp energie } \\
\text { (anders dan wind) en de relatie met het onderwerp natuur }\end{array}$ & $\begin{array}{l}\text { Kennis en/of } \\
\text { innovatie } \\
\text { opgave? }\end{array}$ & $\begin{array}{l}\text { NWA Noordzee in } \\
\text { Transitie voorstel }\end{array}$ \\
\hline \multicolumn{3}{|l|}{ Gedeeltelijke witte vlekvragen } \\
\hline $\begin{array}{l}\text { Hoe kan natuurinclusief bouwen van met name offshore windparken, } \\
\text { en wellicht ook drijvende (onderbroken) eilanden, bijdragen aan } \\
\text { herstel en ontwikkeling van de Noordzeenatuur? }\end{array}$ & Kennis & $x$ \\
\hline
\end{tabular}

herstel en ontwikkeling van de Noordzeenatuur?

Hoe kunnen in een internationale context vraag en aanbod van

Onbekend

$X$

(wind)energie optimaal worden afgestemd door gebruik te maken

van gedeelde infrastructuur op zee?

Wat zijn mogelijkheden voor systemen om getijde-, golfslag- en

Kennis

$X$

zonne-energie te winnen buiten windparken? Welke factoren bepalen

geschikte locaties?

Welke vormen van energieopslag hebben potentie (m.n. de opslag

Kennis

$\mathrm{X}$

van windenergie met de productie van waterstof)?

Zijn systemen om getijde-, golfslag- en zonne-energie te winnen,

Kennis

$x$

inpasbaar in windparken?

\section{Volledige witte vlekvragen}

Drijvende luchthaven c.q. $\mathrm{H} 2$ productie, ook voor kustvaart

Kennis

(zeewierverwerking, vissershaven).

Hoe kan de overheid sturen op medegebruik van offshore

Innovatie

$\mathrm{X}$

windparken?

Hoe kunnen beleidsmakers aan stakeholders prikkels (financieel of

Kennis

$\mathrm{X}$

anderszins) geven om tot natuurinclusieve oplossingen te komen en

bottom up initiatieven voor natuurinclusieve oplossingen te

stimuleren.

Hoe zal de scheepvaartroute langs de Noordpool zich ontwikkelen en

welke gevolgen heeft dat voor het ruimtegebruik in het

Noordwestelijke deel van de Noordzee? 
Inzicht in potentieel, timing en of opschalen realistisch is voor

nieuwe energie en voedsel technieken (bijv. kweektechnieken,

energievliegers, golfenergie)

Kan (een deel van) de olie- en gasinfrastructuur worden behouden

innovatie

om (tijdelijk) te gebruiken voor CO2-opslag?

Kan (een deel van) de uit bedrijf genomen olie- en gasinfrastructuur

Kennis

$x$

voor energieopslag worden ingezet?

Wat is de potentie voor de winning van getijden-, golfslag- en

zonne-energie op de Noordzee? Welke technieken zijn hiervoor

geschikt en wat is hiervan de Technology Readiness Level (TRL)?

Wat is een realistisch verkeersbeeld dat verwacht mag worden door

Kennis

Innovatie

X

aanleg en onderhoud van windparken en andere activiteiten op zee?

Hoe beïnvloedt dit de veiligheid op zee?

Wat is het effect van medegebruik van windparken op de

Innovatie

Kennis

$X$

stroomprijs?

Wat zijn de gevolgen van de opruimplicht die geldt voor offshore

Kennis

installaties voor de dan ontstane natuur? Wat betekent dit voor het

beginsel van 'geen achteruitgang' in de KRM?

Wat zijn de kosten en baten van (de combinatie van) getijden-,

$X$

golfslag- en zonne-energie binnen en buiten offshore windparken?

Welke gebieden zijn geschikt voor CCS (=CO2 opslag) en welke

Kennis

volgorde van ingebruikname is het meest kostenefficiënt?

Welke rol kunnen (drijvende of vaste) energie-eilanden hebben bij

Kennis

de winning, conversie, opslag en transport van energie? 


\section{Bijlage 8 Kennis- en innovatievragen Maricultuur}

Overzicht van de verschillende kennis- en innovatievragen over het onderwerp Maricultuur. Een onderverdeling wordt gemaakt tussen gedeeltelijke en volledige witte vlekken. Per kennisvraag wordt aangegeven of het een kennis-, een innovatieopgave of beiden is.

\begin{tabular}{|c|c|c|}
\hline Kennisvragen Maricultuur & $\begin{array}{l}\text { Kennis- } \\
\text { en/of } \\
\text { innovatie } \\
\text { opgave }\end{array}$ & $\begin{array}{l}\text { Gedekt in NWA } \\
\text { Noordzee in } \\
\text { (afgewezen)Tran } \\
\text { sitie voorstel }\end{array}$ \\
\hline \multicolumn{3}{|l|}{ Gedeeltelijke witte vlekvragen } \\
\hline $\begin{array}{l}\text { Geschikte zeewierrassen voor food en non-foodtoepassingen (inclusief } \\
\text { voedselveiligheidaspecten) }\end{array}$ & Kennis & \\
\hline $\begin{array}{l}\text { Ontwikkelen offshore hardware en logistiek zeewierproductie: } \\
\text { ontwikkeling robuuste en lichte teeltconstructies met lage teeltkosten }\end{array}$ & Innovatie & \\
\hline $\begin{array}{l}\text { Ontwikkelen offshore hardware en logistiek zeewierproductie: } \\
\text { ontwikkeling van gemechaniseerde ent- en oogstmethodes }\end{array}$ & Innovatie & \\
\hline $\begin{array}{l}\text { Ontwikkelen offshore hardware en logistiek zeewierproductie: } \\
\text { oogst/verwerking integreren met andere activiteiten op de Noordzee }\end{array}$ & $\begin{array}{l}\text { Kennis- en } \\
\text { innovatie }\end{array}$ & \\
\hline Platte oesterkweek op de Noordzee: wat kan er en wat is rendabel? & $\begin{array}{l}\text { Kennis- en } \\
\text { innovatie }\end{array}$ & \\
\hline Praktijkconcepten van nieuwe teeltwijzen en/of nieuwe plaatsen & Innovatie & \\
\hline $\begin{array}{l}\text { Reststromen uit zee en meest geschikt gebruik in de food en non-food } \\
\text { keten (hoogwaardige zeewierketen, hoge en laagwaardige componenten } \\
\text { uit zeewier, bijvangst/laagwaardige vissoorten, ) }\end{array}$ & $\begin{array}{l}\text { Kennis- en } \\
\text { innovatie }\end{array}$ & \\
\hline $\begin{array}{l}\text { Samenwerking met Greenport om zeewierteelt + rendement te } \\
\text { optimaliseren }\end{array}$ & Innovatie & \\
\hline $\begin{array}{l}\text { Wat zijn de kansen, beperkingen en risico's voor de combinatie van } \\
\text { maricultuur met andere vormen van gebruik (m.n. windparken) op de } \\
\text { Noordzee? Voor welke technieken en welke soorten is de combinatie } \\
\text { economisch en technisch haalbaar? }\end{array}$ & Kennis & $\mathrm{x}$ \\
\hline $\begin{array}{l}\text { Wat zijn de mogelijkheden om oesterbroedjes op te kweken in vijvers } \\
\text { alvorens ze uit te zetten in windmolenparken? }\end{array}$ & Kennis & \\
\hline $\begin{array}{l}\text { Wat zijn de mogelijkheden voor afzetmarkten voor duurzaam geoogst } \\
\text { (wild of geteeld) zeewier? }\end{array}$ & Kennis & $\mathrm{x}$ \\
\hline $\begin{array}{l}\text { Welke bijdrage levert maricultuur aan klimaatadaptatie en aan de } \\
\text { circulaire economie? }\end{array}$ & Kennis & $\mathrm{x}$ \\
\hline $\begin{array}{l}\text { Welke gebieden op de Noordzee zijn geschikt voor (welke vormen van) } \\
\text { maricultuur? Met inachtneming van kansen en beperkingen in relatie tot } \\
\text { ander ruimtegebruik (waaronder andere vormen van maricultuur), } \\
\text { natuur, logistiek (transport van en naar de kust), golfklimaat, } \\
\text { stromingen, beschikbaarheid van nutriënten, contaminanten, } \\
\text { klimaatverandering, Arbowetgeving en algemene veiligheid. }\end{array}$ & Kennis & $\mathrm{x}$ \\
\hline $\begin{array}{l}\text { Zeewierteelt op de Noordzee: hoeveel kun je kweken zonder te } \\
\text { bemesten? wat zijn de meest geschikte locaties? Is precisiebemesting } \\
\text { mogelijk? Ontwikkeling van groeimodellen als hulpmiddel in onderzoek. } \\
\text { Wat is de productie en samenstelling van de geschikte inheemse } \\
\text { cultivars? Ontwikkeling biobank i.v.m. noodzakelijke genetische } \\
\text { diversiteit. Hoe verleng je het oogstseizoen? }\end{array}$ & Kennis & \\
\hline
\end{tabular}


Innovatieve Kweeksystemen gericht op maximale productie met

Kennis

minimale impact (precisie seagriculture m.n. voor zeewierkweek, met

mogelijkheden voor circulaire

Inzicht in potentieel, timing en of opschalen realistisch is voor nieuwe

Kennis- en

energie en voedsel technieken (bijv. kweektechnieken, energievliegers,

innovatie

golfenergie)

Markt / business cases zeewier uit Noordzee: wat is er nodig om zeewier Kennis

te ontwikkelen tot product geschikt als

gewasbeschermings/versterkingsmiddel in bijv. biologische landbouw

Markt / business cases zeewier uit Noordzee: wat is er nodig om zeewier Kennis

te ontwikkelen tot product geschikt voor humane en/of dierlijke

consumptie en supplement voor de voedingsmiddelenmarkt

Markt / business cases zeewier uit Noordzee: welke bulkgrondstoffen

Kennis

kan grootschalige teelt leveren (eiwitten, laginaat, mannitol)

Markt / business cases zeewier uit Noordzee: welke rol kan

Kennis

grootschalige zeewierteelt spelen als leverancier van energie?

Ontwikkelen en identificeren mogelijkheden nieuwe eiwitbronnen zoals

Kennis

algen, zeewier en insecten

Ontwikkelen nieuwe teeltwijzen op nieuwe plaatsen (o.a. productie op

Kennis

zee)

Ontwikkelen oesterhatchery voor herstelprojecten. Geldt ook voor zeewier

Kennis- en

Ontwikkelen offshore hardware en logistiek zeewierproductie: hoe innovatie

voorkom je overwoekering van teeltsystemen tijdens het groeiseizoen

Ontwikkelen offshore hardware en logistiek zeewierproductie: wat zijn

Kennis

effecten van grote zeewiersystemen op stroming?

Optimale logistieke organisatie van zeewier- en schelpdierketens voor

Kennis

food en non-food toepassingen

Risico's zeewierteelt: kunnen exoten zich gaan vestigen? risico's van

Innovatie

ziekten en plagen in grote monocultures? Kunnen concentraties

Kennis

contaminanten en toxinen de normen overschrijden? Welke risico's voor ondernemers?

Veredelingsprogramma zeewieren: welke inheemse cultivars zijn het

Kennis- en

meest geschikt? Hoe ontwikkel je goede reproductietechnieken? Diepere

innovatie

kennis over genetica zeewier nodig voor effectieve veredeling.

Verwerking zeewier uit grootschalige teeltsystemen: welke

Kennis- en

verwerkingsstappen zijn mogelijk dichtbij het kweekveld? Hoe

innovatie

stabiliseer je geoogst zeewier? ontwikkeling van

fractioneringstechnologieën.

Wat is de draagkracht van de Noordzee voor verschillende vormen van Kennis

maricultuur? Het gaat hier met name om beschikbaarheid van

nutriënten en de effecten van onttrekking van nutriënten.

Wat is de impact van potentiële gevaren (bijvoorbeeld het gebruik van

Kennis

antibiotica, ontsnappen van kweekvis en vermenging van kweekvis met

wilde vis)?

Wat is de totale economische waarde van de huidige maricultuur sector

Kennis

in Nederland en wat zijn mogelijk indirecte effecten op visverwerking en

toelevering bij een verandering in de omvang?

Wat zijn de (maatschappelijke) kosten en baten van maricultuur in

Kennis

windmolenparken?

Wat zijn vanuit sociaaleconomisch perspectief te verwachten scenario's

voor de toekomst van maricultuur op de Noordzee, inclusief soort, 
productiemethoden en omvang? Ook hier: hoe groot is dit economisch belang in potentie?

Welke nieuwe technieken voor maricultuur kunnen op korte en middellange termijn worden toegepast?

Wet- en regelgeving grootschalige zeewierproductie: vroegtijdig in kaart

Innovatie brengen van risico's en belangen van diverse stakeholders. Welke nieuwe regelgeving is nodig? welke regelgeving moet worden aangepast? Governance en aansprakelijkheid bij meervoudig ruimtegebruik

Zijn er kansen voor mobiele maricultuur, bijvoorbeeld op mobiele eilanden of schepen? 


\section{Bijlage 9 Kennis- en innovatieopgaven geschikt voor topsectorfinanciering}

Overzicht van kennis- en innovatieopgaven (geheel of gedeeltelijk witte vlekken) die geschikt zijn voor topsectorfinanciering voor het onderwerp Noordzee, inclusief maricultuur, exclusief visserij.

Kennis- en innovatievragen Noordzee, inclusief maricultuur, exclusief visserij, geschikt voor topsectorinitiatief

Hoe gaat de schaalvergroting van scheepvaart in de toekomst veranderen? Wat is het effect op bv. bemannen van schepen en de ontwikkelingen van autonoom transport?

Hoe ontwikkelt de luchtvaart in de toekomst? Welke effect heeft dit op de ontwikkeling van scheepvaart op de Noordzee?

Inzicht in potentieel, timing en of opschalen realistisch is voor nieuwe energie en voedsel technieken (bijv.

kweektechnieken, energievliegers, golfenergie)

Kan (een deel van) de olie- en gasinfrastructuur worden behouden om (tijdelijk) te gebruiken voor CO2-opslag?

Ontwikkelen oesterhatchery voor herstelprojecten. Geldt ook voor zeewier

Pilot project voor economisch én ecologische haalbaarheid medegebruik (verdienmodel natuurontwikkeling in rendabel model)

Platte oesterkweek op de Noordzee: wat kan er en wat is rendabel?

Samenwerking met Greenport om zeewierteelt + rendement te optimaliseren

Verankering en scour protection als ecologisch 3D netwerk in een windpark

Wat is een realistisch verkeersbeeld dat verwacht mag worden door aanleg en onderhoud van windparken en andere activiteiten op zee? Hoe beïnvloedt dit de veiligheid op zee?

Wat zijn de kosten en baten van (de combinatie van) getijden-, golfslag- en zonne-energie binnen en buiten offshore windparken?

Wat zijn de meest geschikte locaties voor offshore wind vanuit kosten, onderhouds- en ruimtelijk perspectief (na 2030)?

Wat zijn de milieueffecten van de technieken waarmee getijde-, golfslag- en zonne-energie kunnen worden opgewekt? Wat zijn de milieueffecten van drijvende en vaste eilanden op zee?

Wat zijn de mogelijkheden om oesterbroedjes op te kweken in vijvers alvorens ze uit te zetten in windmolenparken? Wat zijn mogelijkheden voor systemen om getijde-, golfslag- en zonne-energie te winnen buiten windparken? Welke factoren bepalen geschikte locaties?

Welke innovaties kunnen ervoor zorgen dat er meer vermogen op de Noordzee geïnstalleerd kan worden? Wat zijn de kosten en baten hiervan?

Welke rol kunnen (drijvende of vaste) energie-eilanden hebben bij de winning, conversie, opslag en transport van energie?

Welke vormen van energieopslag hebben potentie (m.n. de opslag van windenergie met de productie van waterstof)?

Zijn systemen om getijde-, golfslag- en zonne-energie te winnen, inpasbaar in windparken?

\section{Kennisvragen misschien geschikt voor topsectorinitiatief}

Bijdragen aan haalbaarheidsstudie voor Floating airport d.m.v. onderzoeksstation met snelle dataverbinding Drijvende luchthaven c.q. $\mathrm{H} 2$ productie, ook voor kustvaart (zeewierverwerking, vissershaven).

Hoe passen de (extra) kosten van het combineren van wind en natuur in het totale verdienmodel voor offshore windparken? Kan er worden aangegeven welke prijsverhogingen het gevolg zijn van natuurinclusief bouwen als kostenpost? Hoe kunnen deze kosten worden verhaald? Wat zijn de mogelijke baten van het combineren van wind en natuur? En hoe kunnen deze baten worden gestimuleerd?

Kan (een deel van) de uit bedrijf genomen olie- en gasinfrastructuur voor energieopslag worden ingezet? Markt / business cases zeewier uit Noordzee: wat is er nodig om zeewier te ontwikkelen tot product geschikt als gewasbeschermings/versterkingsmiddel in bijv. biologische landbouw

Markt / business cases zeewier uit Noordzee: welke rol kan grootschalige zeewierteelt spelen als leverancier van energie?

Ontwikkelen en identificeren mogelijkheden nieuwe eiwitbronnen zoals algen, zeewier en insecten 
Ontwikkelen offshore hardware en logistiek zeewierproductie: ontwikkeling robuuste en lichte teeltconstructies met lage teeltkosten

Ontwikkelen offshore hardware en logistiek zeewierproductie: ontwikkeling van gemechaniseerde ent- en oogstmethodes

Ontwikkelen offshore hardware en logistiek zeewierproductie: oogst/verwerking integreren met andere activiteiten op de Noordzee

Optimale logistieke organisatie van zeewier- en schelpdierketens voor food en non-food toepassingen

Veredelingsprogramma zeewieren: welke inheemse cultivars zijn het meest geschikt? Hoe ontwikkel je goede reproductietechnieken? Diepere kennis over genetica zeewier nodig voor effectieve veredeling.

Verwerking zeewier uit grootschalige teeltsystemen: welke verwerkingsstappen zijn mogelijk dichtbij het kweekveld? Hoe stabiliseer je geoogst zeewier? ontwikkeling van fractioneringstechnologieën.

Wat is de impact van potentiële gevaren (bijvoorbeeld het gebruik van antibiotica, ontsnappen van kweekvis en vermenging van kweekvis met wilde vis)?

Wat is de potentie voor de winning van getijden-, golfslag- en zonne-energie op de Noordzee? Welke technieken zijn hiervoor geschikt en wat is hiervan de Technology Readiness Level (TRL)?

Wat is het effect van medegebruik van windparken op de stroomprijs?

Wat zijn de kansen voor leefgemeenschappen (habitats) en soorten met het oog op de ontwikkeling van eilanden in zee?

Wat zijn kansen voor natuur bij zandsuppletie?

Welke gebieden zijn geschikt voor CCS (=CO2 opslag) en welke volgorde van ingebruikname is het meest kostenefficiënt?

Welke nieuwe technieken voor maricultuur kunnen op korte en middellange termijn worden toegepast?

Welke risico's en kansen kunnen voortkomen uit opslag van $\mathrm{CO} 2$ op de Noordzee?

Welke rol kan natuurinclusief bouwen spelen bij de versterking van de natuur en het compenseren van de negatieve effecten van wind op zee? Wat zijn de kosten en baten van verschillende mogelijkheden?

Zijn er kansen voor mobiele maricultuur, bijvoorbeeld op mobiele eilanden of schepen?

Welke nieuwe technieken voor maricultuur kunnen op korte en middellange termijn worden toegepast?

Overzicht van kennis- en innovatieopgaven (geheel of gedeeltelijk witte vlekken) die geschikt zijn voor topsectorfinanciering voor het onderwerp Visserij.

Kennisvragen Visserij geschikt voor topsectorinitiatief

Draagt een waterrijk verwerkingsproces bij aan dierwelzijn? En is een dergelijk verwerkingsproces technisch en

financieel haalbaar aan boord?

Hoe gaan de emissies van scheepvaart in de toekomst veranderen? Incl. geluid?

Hoe kan rol visserij-innovatiecentrum vergroot worden?

Kan de natuur gestimuleerd worden om meer voedsel te produceren (bv. "restocking" in windparken of bijvoeden maricultures)? Wat zijn de ecologische en economische (bij)effecten van deze maatregelen?

\section{Kennisvragen misschien geschikt voor topsectorinitiatief}

Hoe haalbaar (technisch, economisch, sociaal, politiek) is het om te komen tot een transitie naar schepen op kernenergie?

Hoe kan de huidige combinatie van schip, vistuig en andere taken en voorstuwingssysteem verder geoptimaliseerd worden?

Hoe kan een visserij selectiever worden, en zo op een kleiner hoeveelheid vis impact hebben?

Hoe kan ruimte op zee op werkbare manier worden ingedeeld voor multi-use? Hoe zit het met beheermodellen m.b.t. multi-use? Hoe kan ruimte op zee voor visserij worden behouden? Inzetbaarheid van visserij-corridors.

Hoe kan voldoende ruimte worden gecreëerd voor de uitrol van wind op zee (na 2030)?

Hoe kan voorspelbaarheid vangst verbeterd worden?

Hoe kun je ervoor zorgen dat een nieuw scheepsontwerp ook financieel interessant is?

Hoe kunnen innovatieve vistechnieken leiden tot kostenbesparing? (brandstofreductie, automatisering, minder

bijvangst, etc.)

Hoe kunnen vissersschepen ingezet worden als onderzoeksplatform (zonder dat de kosten allen bij de sector liggen)? 
In hoeverre kunnen innovaties ontwikkeld worden die met sensoren de juiste vis en de juiste grootte van de vis detecteren alvorens te vissen? (vooruit-scannen, vissen met camera's, juiste vis detecteren, precisie vissen, minder bodemberoering, platvis herkennen, onderwater drone, sonar, echolood)

Is een sneller verwerkingsproces mogelijk? Is een sneller verwerkingsproces het beste te behalen door het automatiseren van het verwerkingsproces of door veranderingen in bemanningsprocessen? Hoe kan dit ingebouwd worden in het huidige verwerkingsproces?

Is het mogelijk om een vistuig te ontwerpen dat selectiever is en langer onder water kan blijven zodat de bemanning een langere rustperiode hebben tussen trekken door?

Is het technisch, economisch en sociaal mogelijk om een vloottransitie te maken naar elektrisch/waterstof/hybride visserijschepen? Wat zijn de belemmeringen die een dergelijke investering in de weg staan (batterijen/vistrip lengte, infrastructuur, initiële investeringskosten, betrouwbaarheid, omscholing, onbekendheid, ideologie) en hoe stimuleer je vissers om de overstap naar meer duurzame brandstof te maken (regelgeving of stimulatie of informatie)?

Kan er een 'buienrader' voor doelsoorten komen, gevoed door gebruik van actuele vangstgegevens?

Kan er een restauratieplan worden ontwikkeld waarin alle aspecten van visserij worden meegenomen, gedragen door maatschappelijke organisaties, visserij en overheid?

Kan er geschikt habitat worden gecreëerd voor kabeljauw (en andere vissoorten, roggen) ter ondersteuning van bestandsontwikkeling?

Kan innovatie bevorderd worden door een doelschrift document te ontwikkelen, i.p.v. technische maatregelen en micromanagement?

Kan kennis over visgedrag en (temporele) aanwezigheid/mix van vissoorten worden vergroot, en kunnen tuigen en methoden daarop aangepast worden (bv ontsnappingspanelen)?

Kan real-time monitoring van bijvangst en voor handhaving uitgevoerd worden, zodat er tijdelijk gesloten gebieden/periodes kunnen worden ingesteld wanneer er veel bijvangst is? Kan er een 'buienrader' voor bijvangstsoorten komen? (Temporeel) dynamische kansen kaart), gevoed door gebruik van actuele (bij)vangstgegevens: jonge vis, haaien). (voorbeeld van doornhaai in Bristol Channel)

Kunnen multi-use schepen gerealiseerd worden? Schepen waarmee men kan vissen met verschillende vistuigen maar bijvoorbeeld ook in windparken kan vissen, of dat een visser aquacultuur onderhoud onderweg naar de visgronden kan uitvoeren.

Onderzoek aan visgedrag. Blijf niet hangen in traditionele vistuigen. Ontwikkel nieuw vistuig concept waarbij vis wel op de bodem gevangen wordt maar de selectie elders plaats vindt. Er kan gedacht worden aan een stofzuigerconcept, overlevingsnetten, passieve visserijen, etc. Kan zwemsnelheid van vis gebruikt worden voor scheiding en selectie? (schol gelijk achterin het net, tong zwemt veel meer mee om te ontsnappen)

Ontwikkelen van innovatieve vistuigen met zo min mogelijke bodemberoering (incl. de nodige governance, betrekken van stakeholders).

Welk medegebruik van windparken is mogelijk met inachtneming van veiligheid, kosteneffectiviteit en technische randvoorwaarden? Hierbij zijn met name interessant bepaalde vormen van visserij, maricultuur, natuurontwikkeling, winning van golf-, zonne- en getijde- energie en energieopslag in o.a. waterstof.

Welke andere activiteiten kunnen (onder welke voorwaarden) gekoppeld worden aan energie-eilanden? Kunnen energie-eilanden waardevol zijn voor de visserij (bv. verblijf bemanning, visverwerking)?

Welke low-impact vismethoden zijn rendabel? Wat is effect op ecosysteem?

Welke vis- of schaaldiersoorten kun je kweken? Welke verdienmodellen en mogelijkheden voor innovatie zijn er, en hoe kan dat gestimuleerd worden?

Welke vorm van visserij past bij de transities op de Noordzee? Waar liggen kansen voor medegebruik? Aan welke voorwaarden moeten (en kunnen) de visserij- en de windenergiesector voldoen om visserij binnen windparken haalbaar en aantrekkelijk te maken? Wat zijn de mogelijkheden voor en economische impact van passieve visserij binnen windparken? Bekijk samen met vissers in simulatiemodellen naar de mogelijkheden van precisievisserij in windmolenparken. Wat is de voor doorvisbaarheid optimale lay out van de windkavels?

Zijn andere verdienmodellen rendabel (combi's van visserij en aquacultuur, vissen binnen windparken, passieve krabben- en kreeftenvisserij in windparken, basisinkomen voor vissers, schepen leasen, alternatieve inkomsten, integratie van visketen in 1 bedrijf: schepen, verwerking, verkoop)? Hoe moeten vissers worden omgeschoold?

Zou innovatie in de visserij bevorderd worden wanneer vissers meer verantwoordelijkheid en rekenschap krijgen in combinatie met meer ruimte om te kunnen innoveren (pilotstudies)? 


\section{Bijlage 10 Kennis- en innovatieopgaven geschikt voor publieke financiering}

Overzicht van kennis- en innovatieopgaven (geheel of gedeeltelijk witte vlekken) die geschikt zijn voor publieke financiering (ministeries) voor het onderwerp Noordzee, inclusief maricultuur, exclusief visserij.

\begin{tabular}{lc}
$\begin{array}{ll}\text { Geheel of gedeeltelijke witte vlekvragen Noordzee, inclusief maricultuur, exclusief } \\
\text { visserij }\end{array}$ & $\begin{array}{l}\text { Kennis- en/of } \\
\text { innovatie opgave }\end{array}$ \\
$\begin{array}{ll}\text { Verankering en scour protection als ecologisch 3D netwerk in een windpark } \\
\text { Wat zijn de meest geschikte locaties voor offshore wind vanuit kosten, onderhouds- en }\end{array}$ & Kennis \\
\hline ruimtelijk perspectief (na 2030)? & Innovatie
\end{tabular}

Overzicht van kennis- en innovatieopgaven (geheel of gedeeltelijk witte vlekken) die geschikt zijn voor publieke financiering (ministeries) voor het onderwerp Visserij.

Geheel of gedeeltelijke witte vlekvragen Visserij

Kennis- en/of

innovatie opgave

Hoe kan rol visserij-innovatiecentrum vergroot worden?

Kennis

Hoe kan voldoende ruimte worden gecreëerd voor de uitrol van wind op zee (na 2030)?

Kennis

Is het technisch, economisch en sociaal mogelijk om een vloottransitie te maken naar

Kennis en innovatie elektrisch/waterstof/hybride visserijschepen? Wat zijn de belemmeringen die een dergelijke investering in de weg staan (batterijen/vistrip lengte, infrastructuur, initiële investeringskosten, betrouwbaarheid, omscholing, onbekendheid, ideologie) en hoe stimuleer je vissers om de overstap naar meer duurzame brandstof te maken (regelgeving of stimulatie of informatie)? Kan er een restauratieplan worden ontwikkeld waarin alle aspecten van visserij worden Kennis meegenomen, gedragen door maatschappelijke organisaties, visserij en overheid? 


\section{Bijlage 11 Kennis- en innovatievragen Visserij}

In deze bijlage worden de kennis- en innovatievragen rondom duurzame visserij gepresenteerd, die zijn overgenomen uit de Noordzee 2030 Agenda, aangevuld met vragen op basis van interviews, de online-enquête en de workshops. De vragen zijn ingedeeld naar subthema en type onderzoek. Eerst worden de (gedeeltelijk) witte vlekken getoond, daarna nog enkele vragen waar wel aan gewerkt wordt.

Kennis- en innovatievragen visserij: witte vlekken (geheel of gedeeltelijk), per subthema.

Kennis- en innovatievragen visserij

betere arbeidsomstandigheden

Consultancy

Hoe kunnen veiligheidsspullen (reddingsvesten, helmen, oorbeschermers) beter ontworpen worden, met de gebruiker in gedachten gehouden? Zo ontwerpen dat ze de drager niet belemmeren tijdens het werk.

Krijgen buitenlandse werknemers gelijke betaling voor hetzelfde werk in de visserijsector? Begrijpen en houden ze zich aan de veiligheidseisen? Welke effecten hebben het inhuren van buitenlandse werknemers op de Nederlandse bemanningsleden?

Kunnen internationale afspraken gemaakt worden zoals over het internationaal erkennen van diploma's van schippers en veiligheidsafspraken aan boord?

Kunnen windparken aangepast worden of werk eilanden of moeder schepen ontwikkeld worden voor vissers (ter overnachting, verwerking enz.)

Wat is het effect van financiële onzekerheid in het betalingssysteem in de visserij (vb. geen minimaal loon)? Is een alternatief model aantrekkelijk voor eigenaars en bemanningsleden?

TO2

Hoe kunnen gewoontes en cultuur aan boord van schepen veranderen om veiligheid meer geaccepteerd te krijgen (vb. gebruik reddingsvesten)? Is verandering in gewoonte/cultuur/gedrag het beste te behalen in het visserij onderwijs of zijn er andere momenten waarin dit beter te behalen is? Zou strengere handhaving effectief zijn?

Is het mogelijk om een vistuig te ontwerpen dat selectiever is en langer onder water kan blijven zodat de bemanning een langere rustperiode hebben tussen trekken door?

Proces Analyse: Hoe kan het werkproces aan boord verbeterd worden om de kans op letsel te verminderen? Welke werkzaamheden kunnen geautomatiseerd worden of vervangen worden door machinerie om het risico voor bemanningsleden te verminderen. Hoe kunnen bestaande schepen aangepast worden en hoe kunnen automatiseringen gerealiseerd worden in een nieuw scheepsontwerp?

Dierenwelzijn

Acad./TO2/consultancy samen

Hoe kan een visserij selectiever worden, en zo op een kleiner hoeveelheid vis impact hebben?

Hoe kan letsel en mortaliteit bij bijvangst (vis, vogels, zoogdieren) vermeden worden?

Systeem analyse: Waar in het proces van net naar doding kan dierwelzijn verbeterd worden?

Wat is het meest humane verdovingstechniek? (onderkoelen en dan verwerken/steken/klap op het hoofd/elektriciteit)

Academisch (uni + NWO)

Is het mogelijk om wetenschappelijk duidelijkheid te krijgen over pijnbeleving bij vissen en de overheid te voorzien van een degelijk breed gedragen advies hierover? Hoe werkt dit door in de visserij? TO2

Draagt een waterrijk verwerkingsproces bij aan dierwelzijn? En is een dergelijk verwerkingsproces technisch en financieel haalbaar aan boord?

Is een snellere verwerkingsproces mogelijk? Is een snellere verwerkingsproces het beste te behalen door het automatiseren van het verwerkingsproces of door veranderingen in bemanningsprocessen? Hoe kan dit ingebouwd worden in het huidige verwerkingsproces?

Is er een markt voor een dierwelzijn certificaat of hoe kan een markt voor een dierwelzijn certificaat gecreëerd worden? Wie gaat over de certificering en controle? Wanneer er een marktvraag voor is zullen vissers dat oppakken (vb. MSC) goede boterham verdienen

Acad./TO2/consultancy samen

Hoe kan de vertegenwoordiging (PO's) en verkoop (visafslagen) efficiënter geregeld worden dan met zoveel opgesplitste organisaties?

Hoe kan innovatie gestimuleerd worden? (beloning)

Hoe kan markt gecreëerd worden voor wisselende garnalenvangsten? 
Kennis- en innovatievragen visserij

Hoe kan minder regelgeving gerealiseerd worden?

Hoe kan regeldruk omlaag?

Hoe kun je ervoor zorgen dat een nieuw scheepsontwerp ook financieel interessant is?

Hoe kun je innovatie stimuleren die pas in toekomst rendabel wordt?

Hoe kunnen innovatieve vistechnieken leiden tot kostenbesparing? (brandstofreductie, automatisering, minder bijvangst, etc.)

Hoe kunnen vissers omgeschoold worden (voor multi-use)

Hoe wordt EU acceptatie van innovaties geregeld?

Is het mogelijk om EU beheersmanagement regionaal aan te passen? Voor de passieve visserij is het zeebaars dossier problematisch op dit vlak.

Is kleinschalige visserij duurzamer? En zo ja, kunnen quota richting kleinschalige visserij gaan? Kan overheid hun organisatie/vertegenwoordiging ondersteunen?

Kan er een restauratieplan worden ontwikkeld waarin alle aspecten van visserij worden meegenomen, gedragen door maatschappelijke organisaties, visserij en overheid?

Wat is effect van contract-vissen op ecosysteem (bv schol voor supermarkt)?

Wat is effect van stabiliteit (beleid) op bestaanszekerheid vissers?

Wat zijn de effecten van een eventuele opschaling van wind op zee op andere activiteiten in de Noordzee?

Wat zijn de gevolgen van klimaatverandering voor bestaande, opkomende en nieuwe economische sectoren en wat betekenen eventuele veranderingen voor de druk op de Noordzeenatuur?

Wat zijn de kosten en baten van verschillende alternatieve locaties voor wind op zee, zowel voor de energiemaatschappij, als voor de overige sectoren, zoals de visserij, scheepvaart, recreatie, etc. (kortom, de rest van de maatschappij)?

Wat zijn de sectoraal-economische effecten van ruimtelijke ontwikkelingen op de Noordzee tot 2030 (en indien kwantificeerbaar na 2030), inclusief de ontwikkeling van de concurrentiepositie? Met name van de grootschalige uitrol van windenergie. Wat zijn de economische effecten op de economische ontwikkelingen op de Nederlandse zeehavens? En verder op land gebonden economische activiteiten?

Welke andere activiteiten kunnen (onder welke voorwaarden) gekoppeld worden aan energie-eilanden? Kunnen energie-eilanden waardevol zijn voor de visserij (bv. verblijf bemanning, visverwerking)?

Welke factoren maken visser 'happy'? Bij welke arbeidsomstandigheden?

Welke kennisuitwisseling zou tot kostenreductie leiden? (transparante communicatie van vissers, visserijkennis gebruiken, meer info delen onder vissers, met wetenschap, internationaal, 'buienradar' voor vissen, gedeeld eigenaarschap problemen)

Welke low-impact vismethoden zijn rendabel? Wat is effect op ecosysteem?

Welke vis- of schaaldiersoorten kun je kweken? Welke verdienmodellen en mogelijkheden voor innovatie zijn er, en hoe kan dat gestimuleerd worden?

Zijn andere verdienmodellen rendabel (combi's van visserij en aquacultuur, vissen binnen windparken, passieve krabben- en kreeftenvisserij in windparken, basisinkomen voor vissers, schepen leasen, alternatieve inkomsten, integratie van visketen in 1 bedrijf: schepen, verwerking, verkoop)? Hoe moeten vissers worden omgeschoold? Zijn andere vormen van bedrijfsvoering duurzamer? (Consolidatie, opschaling, coöperaties i.p.v. familiebedrijven, minder schippers en bemanning, leasen van contigent). Kan macht in handen van kleiner aantal vissers gebalanceerd blijven met transparantie?

Hoe kan ruimte op zee op werkbare manier worden ingedeeld voor multi-use? Hoe zit het met beheermodellen m.b.t. multi-use? Hoe kan ruimte op zee voor visserij worden behouden? Inzetbaarheid van visserij-corridors.

Academisch (uni + NWO)

Stel dat Noordzee in delen aan private partijen zou kunnen worden verkocht, wat zou effect zijn als Ngo's en vissers dat zouden kopen? (meer verantwoordelijkheid?)

Consultancy

Hoe kan vak van visserman interessant blijven voor de jeugd?

Welke vaardigheden hebben toekomstige bemanningsleden nodig?

TO2

Hoe kan duurzame NL/EU vis gepromoot worden (wild, kweek) ten gunste van import uit bv. Azië? Wat is het draagvlak hiervoor? Meer kwaliteit, minder kwantiteit. Hoe kan NL vis in Europa beter worden gepromoot?

Hoe kan rol visserij-innovatiecentrum vergroot worden?

Hoe kan voldoende ruimte worden gecreëerd voor de uitrol van wind op zee (na 2030)?

Hoe kunnen bijvangstproducten leiden tot extra inkomen? Hoe kan passieve visserij en hun bijvangst leiden tot extra inkomen?

Hoe zit het met de tussenhandel: kan minder marge voor tussenhandel zorgen voor betere prijs voor visser?

Je moet erachter komen waar in de visserijsector je kunt veranderen: welke schakels zitten er in de hele keten van het moment van opvissen tot in de winkel. En waar kun je dan veranderingen doorvoeren?

Kunnen de quota ook worden opgevist als de nu voorgestelde beschermde gebieden op zee en offshore windparken worden aangelegd, en waar ligt het kantelpunt?

Kunnen de quota ook worden opgevist als de nu voorgestelde beschermde gebieden op zee en offshore windparken worden ingesteld of aangelegd, en waar ligt het kantelpunt? 
Kennis- en innovatievragen visserij

Kunnen innovatiekosten bij consument doorberekend worden? (Vis duurder maar duurzamer)

Staat subsidie (innovatie, etc.) in verhouding tot opbrengsten? Is industrie zonder subsidie levensvatbaar?

Wat is de impact van windparken en natuurgebieden op inkomen vissers?

Wat zijn geschikte alternatieve vislocaties (i.p.v. gesloten gebieden)? Is de toepassing van viskavels een uitvoerbaar idee? Wat zijn hiervan de kosten en andere sociaal economische effecten?

Wat zijn met het oog op de transitie, waarvoor de visserijsector staat, de consequenties voor de arbeidsmarkt?

Wat zijn voor de visserijsector, incl. de visverwerkende industrie, en visbestanden de (cumulatieve) effecten (o.a. op inkomsten) van de volgende vier ontwikkelingen: (1) een verbod op de pulskor, (2) de Brexit, (3) het sluiten van nieuw aangewezen natuurgebieden voor (bepaalde vormen van) visserij en (4) een (grootschalige) uitrol van wind op zee? Wat betekenen deze ontwikkelingen voor het vermogen om de visquota te benutten?

Welk medegebruik van windparken is mogelijk met inachtneming van veiligheid, kosteneffectiviteit en technische randvoorwaarden? Hierbij zijn met name interessant bepaalde vormen van visserij, maricultuur, natuurontwikkeling, winning van golf-, zonne- en getijde- energie en energieopslag in o.a. waterstof.

Welke sociaaleconomische impact heeft cumulatie van drukfactoren op betrokken sectoren en andere gebruikers van de zee?

Welke vorm van visserij past bij de transities op de Noordzee? Waar liggen kansen voor medegebruik? Aan welke voorwaarden moeten (en kunnen) de visserij- en de windenergiesector voldoen om visserij binnen windparken haalbaar en aantrekkelijk te maken? Wat zijn de mogelijkheden voor en economische impact van passieve visserij binnen windparken? Bekijk samen met vissers in simulatiemodellen naar de mogelijkheden van precisievisserij in windmolenparken. Wat is de voor doorvisbaarheid optimale lay out van de windkavels?

\section{minder bodemberoering}

Acad./TO2/consultancy samen

Gebiedstoewijzing op basis van kwetsbaarheid en hoge veerkracht (al onderhevig aan hoge bodemdynamiek) van gebieden. Is het mogelijk de visserij te concentreren op de gebieden met een hoge veerkracht en de kwetsbare gebieden met een lage veerkracht te beschermen? In hoeverre zijn de gebieden met een hoge veerkracht interessant voor de visserij? (Vangst, doelsoorten, bereikbaarheid)? Welke socio-economische gevolgen zijn er al gevolg van een dergelijke verdeling?

Is er een wetenschappelijke basis voor het argument dat bodemberoerende vissen goed voor de bodem is, in hetzelfde manier van ploegen in een veld? In hoeverre is bodemberoering door visserij te vergelijken met bodemberoering door heftige najaarsstorm of zandwinning, windparken, mijnbouw, pijpen/kabels in graven etc.? Is er een knikpunt tussen bodemberoering dat positief kan bijdragen aan het ecosysteem en wanneer het alleen een negatieve impact heeft? Kan een keuze voor offshore windparken in gebieden met waardevol bodemleven natuurwinst opleveren als deze gebieden worden gesloten voor visserij?

Wat is het effect van verschillende vismethoden op de bodem, en het bodemleven? Wat zijn de effecten van nieuwe vistuigen op het mariene ecosysteem? TO2

Is de kennis uit het BENTHIS project toereikend of moet er nog aanvullend werk uitgevoerd worden?

Is het een optie om over te stappen naar een passieve visserij voor platvis? Wat zijn de voor-en nadelen van een transitie naar passieve vistuigen?

Is het mogelijk om een soort credit-systeem te ontwerpen waarin een schip een bepaald quota van vissen in kwetsbare gebieden heeft? (vb. 12 uren in een kwetsbaar gebied is evenveel waard als 48 uren op een zanderige zeebodem) Onderzoek naar het toepassen van periodieke gesloten gebieden, (i.p.v. permanent gesloten gebieden) waarbij de gebieden tijdens de tijdelijke sluiting kunnen herstellen. Hoe lang dienen gebieden gesloten te zijn alvorens ze hersteld zijn en weer beschikbaar zijn voor visserij?

Ontwikkelen van innovatieve vistuigen met zo min mogelijke bodemberoering (incl. de nodige governance, betrekken van stakeholders).

Wat is de efficiëntie van elk schip, gemeten in opbrengst aan vis/eiwitten per hoeveelheid bodemberoering en/of impact op de zeebodem? Hoe kunnen wij bodemberoering of impact goed meten? Kan een minimum efficiëntie of maximum impact per $\mathrm{kg}$ van vis een criterium worden voor een vis licentie?

Wat zijn de voor- en nadelen van een transitie van grote schepen naar meerder kleinere schepen met lichtere netten?

Zijn de gebieden die nu voorgesteld worden om geheel te sluiten voor bodemberoerende visserij groot genoeg om te voldoen aan de eis van de Europese regelgeving (VHR en KRM). Zijn er andere belangrijke ecologische gebieden die nog aangewezen en beschermd moeten worden, en welke veldkennis is hier nog voor nodig?

\section{minder emissie}

\section{Acad./TO2/consultancy samen}

Hoe haalbaar (technisch, economisch, sociaal, politiek) is het om te komen tot een transitie naar schepen op kernenergie?

Hoe kan de huidige combinatie van schip, vistuig en andere taken en voorstuwingssysteem verder geoptimaliseerd worden?

Is het technisch, economisch en sociaal mogelijk om een vloottransitie te maken naar elektrisch/waterstof/hybride visserijschepen? Wat zijn de belemmeringen die een dergelijke investering in de weg staan (batterijen/vistrip lengte, infrastructuur, initiële investeringskosten, betrouwbaarheid, omscholing, onbekendheid, ideologie) en hoe stimuleer je vissers om de overstap naar meer duurzame brandstof te maken (regelgeving of stimulatie of informatie)? Kunnen multi-use schepen gerealiseerd worden? Schepen waarmee men kan vissen met verschillende vistuigen maar bijvoorbeeld ook in windparken kan vissen, of dat een visser aquacultuur onderhoud onderweg naar de visgronden kan uitvoeren. 
Systeemanalyse: Hoe kan de NL vloot efficiënter worden? (door nieuwe grotere schepen met meer capaciteit - minder verlies van brandstof stomen van en naar visgronden; waterstof/elektrisch; minder schepen; betere visdetectiesystemen; gedragsverandering schippers - plannen van vistrips o.b.v. brandstof efficiëntie?)

Wat zijn mogelijkheden om te faciliteren dat vissers nog efficiënter omgaan met hun tijd op zee en zorg je dat ze het stomen tussen of naar visgronden beperken?

TO2

Hoe stimuleer je vissers om de overstap naar duurzamere brandstof te maken? (regelgeving, of stimulatie?

gecombineerd informatiesysteem van alle vissers samen?)

Wat is de efficiëntie van elk schip, gemeten in kgs vis op de markt per ton emissies? Wat is het meest efficiënte vangst/vis-uur? Kan een minimum efficiëntie een criterium worden voor een vis licentie?

Wat is het effect van een emissie quotum in de visserij? Hoe zou een dergelijk quotum verdeeld moeten worden en gehandhaafd moeten worden? Welke sociaaleconomische effecten komen hierbij kijken?

Wat zijn de mogelijkheden en afwegingen in het gebruik van passieve vistuigen zoals vangkamers, staand want netten, lichter tuig zoals handlijnen en korven? Dragen dergelijke tuigen bij aan minderbrandstof gebruik per $\mathrm{kg}$ vis op de markt?

Zou een weekendstop of het reduceren van het aantal visdagen per schip leiden tot lagere emissies? welke ecologische, socio-economische effecten komen hierbij kijken?

\section{Overig (niet ingedeeld naar thema)}

Acad./TO2/consultancy samen

Hoe kunnen duurzaamheid en ecologie goed ingebed worden in het visserijonderwijs? Wanneer worden studenten en docenten getriggerd om eraan te denken? Hoe kan de verbinding van kennis met het visserijonderwijs verbeterd worden?

Hoe kunnen vissersschepen ingezet worden als onderzoeksplatform (zonder dat de kosten allen bij de sector liggen)?

Hoe verhoudt de ecologische voetafdruk van de visserij op de Noordzee zich tot andere productiesectoren van dierlijke eiwitten?

Kan de natuur gestimuleerd worden om meer voedsel te produceren (bv. "restocking" in windparken of bijvoeden maricultures)? Wat zijn de ecologische en economische (bij)effecten van deze maatregelen?

Kan er een 'buienrader' voor doelsoorten komen, gevoed door gebruik van actuele vangstgegevens?

Kan er geschikt habitat worden gecreëerd voor kabeljauw (en andere vissoorten, roggen) ter ondersteuning van bestandsontwikkeling?

Wat is de draagkracht van de Noordzee voor de activiteiten en het ruimtegebruik die gepaard (kunnen) gaan met de energie- en voedseltransitie?

Wat is de impact van natuurgebieden en windparken op visbestanden?

Wat is er voor nodig om de afstand tussen onderzoekers, beleid en vissers verder te overbruggen?

Wat zijn de effecten van de energie-, voedsel- en natuur transities op de Noordzee voor de lagere trofische niveaus van het voedselweb van de Noordzee? Wat zijn de effecten van overige activiteiten?

Wat zijn de effecten van specifieke overheidsinstrumenten om doelen van sectoren en overheid te realiseren? Met name van voortschrijdende normstelling, fondsvorming, en financiële incentives)

Welke randvoorwaarden stellen netwerken van beschermde gebieden op zee aan het gebruik van de Noordzee? En om deze netwerken te verbeteren, hoe en waar kan dit het beste worden gedaan?

Zou innovatie in de visserij bevorderd worden wanneer vissers meer verantwoordelijkheid en rekenschap krijgen in combinatie met meer ruimte om te kunnen innoveren (pilotstudies)?

Academisch (uni + NWO)

Welke andere activiteiten op de Noordzee hebben naast wind op zee een impact op kwetsbare soorten? Kunnen deze activiteiten makkelijker gemitigeerd worden? Kan in een cumulatieboekhouding worden bijgehouden welke activiteiten hoeveel druk uitoefenen op dezelfde kwetsbare soorten?

TO2

Hoe gaan de emissies van scheepvaart in de toekomst veranderen? Incl. geluid?

Hoe kan de uitvoering van haalbaarheidsstudies en pilotprojecten beter worden geregeld (minder bodemberoering, dierwelzijn, selectiviteit, alternatieve technieken?

Hoe kan ervoor gezorgd worden dat pilots niet onbedoeld blijven steken in het proces om tot de markt toe te treden? Wat is daarbij de rol van de overheid?

Hoe kun je met zo weinig mogelijk vistijd het quota opvangen?

Kan met de toekomstige ontwikkelingen op het gebied van de uitrol van wind op zee de huidige uitvoering van de WOT taken op het gebied van visserijonderzoek nog worden uitgevoerd?

Waar liggen kansen voor verdere verduurzaming van visserij zoals aanpassingen van huidige vismethoden, overschakeling op andere vismethoden, doelsoorten of andere werkzaamheden? Hoe wordt in dit kader duurzaamheid gedefinieerd?

Wat zijn de effecten van innovatieve vangsttechnieken als precisie-, flyshoot- en twinrigvisserij op de opbrengst, ongewenste bijvangst, spooknetten, bodem en bodemleven, vispopulaties en de brandstofkosten? Wat zijn de kosten en opbrengsten van een transitie in de visserij en wat is de investeringsdrempel?

Welke kostenkentallen kunnen worden gehanteerd m.b.t. kabels, zandwinning, en andere activiteiten op zee? 
Hoe kan de tijd op zee door vissers gebruikt worden om gegevens voor het onderzoek te verzamelen? Welke technische innovatie moet ontwikkeld worden om vissersschepen onderzoeksinformatie te laten verzamelen? Hoe kan deze informatie live inzichtelijk gemaakt worden voor beïnvloeding van keuzes visgronden? Welke informatie is waardevol om voor onderzoek te laten verzamelen? Met welk type visserijen kan dit? (kleinschalig?)

Hoe kan handhaving worden verbeterd op illegaal gedrag op legale vissersschepen (binnen-netten, verboden gebieden)

Hoe kan op basis van een ecosysteembenadering bepaald worden hoeveel van welke soort wanneer gevangen mag worden, i.p.v. TAC/quota per soort (wat brengt ecosysteem op, rekening houdend met leeftijdsevenwicht in bestanden enz.?)

Hoe kan voorspelbaarheid vangst verbeterd worden?

In hoeverre kunnen innovaties ontwikkeld worden die met sensoren de juiste vis en de juiste grootte van de vis detecteren alvorens te vissen? (vooruit-scannen, vissen met camera's, juiste vis detecteren, precisie vissen, minder bodemberoering, platvis herkennen, onderwater drone, sonar, echolood)

Is het mogelijk om de onwerkbare aanlandplicht om te zetten naar een werkbare discardban waarbij alles goed geregisterd wordt?

Is het mogelijk om vissers meer ruimte te geven om te experimenteren en hun methodes te verbeteren? Huidige regelgeving belemmert innovatie en de wil hiertoe.

Kan kennis over visgedrag en (temporele) aanwezigheid/mix van vissoorten worden vergroot, en kunnen tuigen en methoden daarop aangepast worden (bv ontsnappingspanelen)?

Kun je bij ontwikkeling van nieuwe tuigen uitgaan van maximalisatie van vangst per $\mathrm{m} 2$ ?

Kunnen we doelgerichter vissen door technologische innovatie in vangst selectie (ontsnappingsluiken, selectie op juiste maat, voorkomen dan wel vergroten overleving van bijvangst en ondermaatse vis, aanpassen maaswijdte, automatisch sorteren)

Onderzoek aan visgedrag. Blijf niet hangen in traditionele vistuigen. Ontwikkel nieuw vistuig concept waarbij vis wel op de bodem gevangen wordt maar de selectie elders plaats vindt. Er kan gedacht worden aan een stofzuigerconcept, overlevingsnetten, passieve visserijen, etc. Kan zwemsnelheid van vis gebruikt worden voor scheiding en selectie? (schol gelijk achterin het net, tong zwemt veel meer mee om te ontsnappen)

Op welke soorten is het goed mogelijk om selectief te vissen zonder schade aan ongewenste soorten te veroorzaken? Kun je een integraal plan maken voor soorten waarvoor dit niet mogelijk is hoe je met de vangst omgaat en afwegen of het inclusief bijvangst überhaupt mogelijk is duurzaam te vissen op een geselecteerde soort.

Wat is de toekomst van de aanlandplicht? Is het mogelijk om dit om te zetten naar een werkbare discardban waarbij alles goed geregisterd wordt? Is een volledige aanlandplicht de oplossing, met boetes voor choke species i.p.v. het sluiten van de visserij?

Welke invloed heeft visserij voor vismeel als diervoeder?

\section{TO2}

Hoe kan meer ruimte gecreëerd worden voor innovatie (financieel, regelgeving) en hoe zorg je ervoor dat efficiëntere en duurzamere visserij omarmd wordt door vissers en maatschappij?

Kan innovatie bevorderd worden door een doelschrift document te ontwikkelen, i.p.v. technische maatregelen en micromanagement?

Kan real-time monitoring van bijvangst en voor handhaving uitgevoerd worden, zodat er tijdelijk gesloten gebieden/periodes kunnen worden ingesteld wanneer er veel bijvangst is? Kan er een 'buienrader' voor bijvangstsoorten komen? (Temporeel) dynamische kansen kaart), gevoed door gebruik van actuele (bij)vangstgegevens: jonge vis, haaien). (voorbeeld van doornhaai in Bristol Channel)

Kan vloot uitgerust worden met camera's om real-time informatie over visserij te krijgen (met respect privacy)? Hoe kan deze kennis ingezet worden t.b.v. selectiever vissen?

Zorgt betere handhaving voor hogere overlevingskansen bijvangst?

\section{Kennis- en innovatievragen visserij: bekende vragen (geen witte vlekken), per subthema.}

\section{Kennis- en innovatievragen: bekende vragen (geen witte vlekken)}

\section{betere arbeidsomstandigheden}

Consultancy

Is het mogelijk om een klein GPS/AIS apparaat te bevestigen aan elk bemanningslid, zodat mocht een bemanningslid overboord gaan, ze traceerbaar zijn?

\section{Dierenwelzijn}

TO2

Draagt een kortere trektijd bij aan dierwelzijn?

goede boterham verdienen

TO2

Wat zijn de sociaalecologische effecten van het sluiten van gebieden voor de visserij?

\section{Overige vragen (niet ingedeeld naar thema)}

Acad./TO2/consultancy samen

Welke methodologieën om cumulatieve effecten mee te beoordelen zijn geschikt om te betrekken bij beleidvorming? 


\title{
Bijlage 12 MMIP Duurzame en veilige Noordzee
}

\author{
MMIP Duurzame en veilige Noordzee, oceanen en binnenwateren - Versie 1 juni 2019 \\ Missie E, Subthema 1: Duurzame en veilige Noordzee
}

\section{Samenvatting}

Het MMIP Duurzame en veilige Noordzee richt zich op het ontwikkelen van duurzaam en veilig menselijk medegebruik binnen een veerkrachtig Noordzee ecosysteem en het ontwikkelen van meer inzicht in de grenzen van de veerkracht van de Noordzee. De focus ligt daarbij op medegebruik van hernieuwbare energie infrastructuur voor natuur en voedselproductie en veilige scheepvaart voor mens, milieu en economie. Er zijn aparte MMIPs 'Visserij' (Missie E) en 'Biogrondstoffen' (Missie B) uitgewerkt. Deze drie MMIPs kunnen niet los van elkaar worden gezien. Het MMIP Duurzame Noordzee kent vier deelprogramma's: (1) Monitoring, modellering, data- en informatiemanagement en afwegingskaders voor menselijk medegebruik binnen de draagkracht van het Noordzee ecosysteem; (2) Natuurvriendelijke aanleg van grootschalige bouwwerken voor energieproductie en stimulering van natuur hierbinnen; (3) Meervoudig ruimtegebruik door combinaties van energie infrastructuur met voedselproductie (visserij en maricultuur ${ }^{2}$ ); (4) Vermindering van afval in zee; en (5) Verhoging van de scheepvaartveiligheid door verbeterde en slimmere schepen en goed ondersteunde en voorbereide bemanningen.

Binnen de bovengenoemde deelprogramma's liggen de prioriteiten bij: (a) kennisontwikkeling over de omvang van 'zog-effecten' van wind op zee en stratificatie-effecten en hoe deze doorwerken op het ecosysteem; (b) versterken van de kennisbasis over de gevolgen van klimaatverandering voor de zeespiegelstijging in 2100 (inzet Noordzee hulpbronnen voor kustverdediging) en het ecosysteem en gebruiksfuncties; (c) fundamentele en toegepaste kennisontwikkeling over inzet van innovatieve (remote), praktisch uitvoerbare monitoringstechnieken; (d) ontwikkeling van risicobeoordeling van cumulatieve effecten van menselijk gebruik; (e) ontwikkeling van een integraal afwegingskader voor inpassing van menselijke ingrepen en activiteiten binnen de grenzen van de draagkracht van het Noordzee ecosysteem, ( $f$ ) stimuleren van natuurontwikkeling bij aanleg offshore installaties; (g) pilots rond meervoudig ruimtegebruik, $(h)$ kennisontwikkeling over de technische en ecologische kosten en baten van waterstofopslag, (i) het voorkomen van extreme scheepsbewegingen (voor lading en passagiers), en ( $\mathrm{j}$ ) het verlagen van aanvaringsrisico's door adviessystemen en (simulator)onderzoek naar de menselijke factor. Voor de meeste van deze prioriteiten zijn geen lopende onderzoeksprojecten en zullen nieuwe programma's moeten worden opgezet.

\section{Inleiding}

Door de vele al aanwezige en geplande activiteiten (o.a. energietransitie) en klimaatverandering staan de kwaliteit en het beheer van de Noordzee onder druk. Het economisch belang en de potenties van de Noordzee zijn groot, zowel voor de voedselvoorziening, energietransitie, transport over water als recreatie. De Noordzee vormt vanuit het perspectief van klimaatverandering ook een bedreiging, waartegen Nederland zich moet beschermen. Vanuit deze achtergrond heeft het kabinet de missie Duurzame en veilige Noordzee vastgesteld. Hierbinnen geldt voor de Kennis- en Innovatieagenda van Landbouw, Natuur en Voedselkwaliteit de volgende missie: "Voor de mariene wateren is er in 2030 en voor rivieren, meren en estuaria in 2050 een balans tussen enerzijds ecologische draagkracht en waterbeheer (waterveiligheid, zoetwatervoorziening en waterkwaliteit) en anderzijds de opgaven voor hernieuwbare energie, voedsel, visserij en andere economische activiteiten."

Een Duurzame Noordzee is onlosmakelijk verbonden met een veilige Noordzee.

Scheepvaartveiligheid is essentieel voor de mensen (passagiers en bemanning) aan boord, het

\footnotetext{
${ }^{2}$ De kweek van vis, schaal- en schelpdieren, wieren en algen in zoute wateren.
} 
milieu (lekkage van gevaarlijke en vervuilende stoffen, overboord slaan van lading zoals containers) en de economie (verloren lading, blokkade van havens en vaarwegen).

\section{Wat beoogt het MMIP?}

Doel

Menselijk medegebruik vindt binnen de context van de (energie)transitie op de Noordzee plaats binnen de ecologische en fysische grenzen van het ecosysteem. Een veerkrachtig ecosysteem is de basis voor economisch en sociaal duurzaam menselijk medegebruik. Scheepvaart op Noordzee gebeurt zodanig dat dit veilig is voor mens, milieu en economie.

Het MMIP omvat de ontwikkeling van kennis, concepten, ondersteunende technologie en maximale implementatie in de praktijk (van reeds bestaande technieken) voor:

- monitoring, modellering, data- en informatiemanagement en afwegingskaders voor menselijk medegebruik binnen de draagkracht van het Noordzee ecosysteem;

- $\quad$ natuurvriendelijke aanleg van grootschalige bouwwerken voor energieproductie (inclusief verminder van onderwatergeluid) en stimulering van natuur hierbinnen;

- meervoudig ruimtegebruik door combinaties van energie infrastructuur met voedselproductie (visserij en maricultuur);

- vermindering van afval in zee;

- $\quad$ verhoging van de scheepvaartveiligheid door verbeterde schepen en systemen.

\section{Deelprogramma's en fasering}

De Noordzee is in aard en omvang onderwerp van een groot aantal nationaal en internationaal onderzoeksprojecten. Internationaal, omdat het ecosysteem en fysisch systeem van de Noordzee niet eindigt bij de grenzen van het Nederlands Continentaal Plat. Hieronder een overzicht van de belangrijkste (door)lopende nationale programma's en projecten voor de missie Duurzame en veilige Noordzee. In de Programmeringsstudie Noordzee ${ }^{3}$ is een uitgebreider overzicht met toelichting opgenomen voor het deel Duurzame Noordzee.

\begin{tabular}{|l|l|l|l|l|}
\hline Onderwerp & $\begin{array}{l}\text { Onderzoeksfase TRL } \\
1-3\end{array}$ & $\begin{array}{l}\text { Ontwikkelfase TRL 4-6 } \\
\text { (toegepast onderzoek, } \\
\text { (NWO, KNAW, EU, } \\
\text { Keleidsondersteunend } \\
\text { Kennis-basis, } \\
\text { strategische } \\
\text { middelen etc.) }\end{array}$ & $\begin{array}{l}\text { Demonstratiefase TRL } \\
7-9 \text { (MIT, POP, } \\
\text { fieldlabs, etc.) }\end{array}$ & $\begin{array}{l}\text { Implementatiefase } \\
\text { (subsidies, } \\
\text { investeringen, } \\
\text { regelgeving, } \\
\text { kennisverspreiding, } \\
\text { netwerken, campagnes } \\
\text { etc.) }\end{array}$ \\
\hline
\end{tabular}

Deelprogramma 1: Deelprogramma 1: Monitoring, modellering, data- en informatiemanagement en afwegingskaders voor menselijk medegebruik binnen de draagkracht van het Noordzee ecosysteem

\begin{tabular}{|c|c|c|c|c|}
\hline & $\begin{array}{l}\text { Kennisbasis (KB) } \\
\text { middelen voor } \\
\text { Wettelijke } \\
\text { Onderzoekstaken } \\
\text { (WOT) (o.a. e-DNA } \\
\text { technieken) } \\
\text { Kennis voor het } \\
\text { Primaire Proces van } \\
\text { RWS }\end{array}$ & $\begin{array}{l}\text { WOT Natuur } \\
\text { WOT Visserij } \\
\text { WOZEP (ecologische } \\
\text { monitoring wind op zee) }\end{array}$ & & Informatiehuis Marien \\
\hline \multicolumn{5}{|c|}{$\begin{array}{l}\text { Deelprogramma 2: Natuurvriendelijke aanleg van grootschalige bouwwerken voor energieproductie en stimulering } \\
\text { van natuur hierbinnen }\end{array}$} \\
\hline & $\begin{array}{l}\text { Beleidsondersteunend } \\
\text { Onderzoek (BO) }\end{array}$ & & $\begin{array}{l}\text { Aantal pilots door WNF, } \\
\text { St. Ark en St. de } \\
\text { Noordzee i.s.m. }\end{array}$ & \\
\hline
\end{tabular}

\footnotetext{
${ }^{3}$ Steins, N.A., Van den Boogaart, L., Maarse, M., Smith, S., Tamis, J., \& Tatman, Sh. (2019). Duurzame Noordzee - Programmeringsstudie landbouw, Water en Voedsel. IJmuiden: Wageningen Marine Research, rapport nummer 1928089.
} 


\begin{tabular}{|c|c|c|c|c|}
\hline Onderwerp & $\begin{array}{l}\text { Onderzoeksfase TRL } \\
\text { 1-3 } \\
\text { (NWO, KNAW, EU, } \\
\text { Kennis-basis, } \\
\text { strategische } \\
\text { middelen etc.) }\end{array}$ & $\begin{array}{l}\text { Ontwikkelfase TRL 4-6 } \\
\text { (toegepast onderzoek, } \\
\text { beleidsondersteunend } \\
\text { onderzoek) }\end{array}$ & $\begin{array}{l}\text { Demonstratiefase TRL } \\
\text { 7-9 (MIT, POP, } \\
\text { fieldlabs, etc.) }\end{array}$ & $\begin{array}{l}\text { Implementatiefase } \\
\text { (subsidies, } \\
\text { investeringen, } \\
\text { regelgeving, } \\
\text { kennisverspreiding, } \\
\text { netwerken, campagnes } \\
\text { etc.) }\end{array}$ \\
\hline & $\begin{array}{l}\text { Natuurinclusieve } \\
\text { energie }\end{array}$ & & $\begin{array}{l}\text { windenergie bedrijven } \\
\text { en onderzoeksinstituten }\end{array}$ & \\
\hline \multicolumn{5}{|c|}{$\begin{array}{l}\text { Deelprogramma 3: Meervoudig ruimtegebruik door combinaties van energie infrastructuur met voedselproductie } \\
\text { (visserij en maricultuur) }\end{array}$} \\
\hline & $\begin{array}{l}\text { KB-programma (o.a. } \\
\text { projecten rond Blue } \\
\text { Growth) }\end{array}$ & $\begin{array}{l}\text { BO Natuurinclusieve } \\
\text { visserij } \\
\text { TKI Wind op zee (diverse } \\
\text { projecten) } \\
\text { Maatschappelijk } \\
\text { Innovatieprogramma } \\
\text { Seaweed for Food and } \\
\text { Feed }\end{array}$ & & \\
\hline \multicolumn{5}{|c|}{ Deelprogramma 4: Vermindering van afval in zee } \\
\hline & & $\begin{array}{l}\text { Diverse } \\
\text { onderzoeksprojecten } \\
\text { plastic in zee Wageningen } \\
\text { Marine Research }\end{array}$ & $\begin{array}{l}\text { KIMO Fishing for litter } \\
\text { OSPAR } \\
\text { strandafvalmonitoring } \\
\text { (St. de Noordzee) }\end{array}$ & $\begin{array}{l}\text { Jaarlijkse Beach Clean Up } \\
\text { St.Noordzee/Boskalis }\end{array}$ \\
\hline \multicolumn{5}{|c|}{ Deelprogramma 5: Verhoging van de scheepvaartveiligheid door verbeterde schepen en systemen } \\
\hline & $\begin{array}{l}\text { Ontwikkeling van } \\
\text { complexe voorspellings- } \\
\text { en simulatiemodellen, } \\
\text { Kunstmatige } \\
\text { Intelligentie technieken } \\
\text { en Human Factor } \\
\text { onderzoek }\end{array}$ & $\begin{array}{l}\text { Toepassing van deze } \\
\text { nieuwe technieken in } \\
\text { toegepast onderzoek } \\
\text { (experimenteel, op } \\
\text { simulatoren en op zee), } \\
\text { ontwikkeling van } \\
\text { autonome en } \\
\text { adviessystemen }\end{array}$ & $\begin{array}{l}\text { Toepassing op nieuwe } \\
\text { scheepsontwerpen. } \\
\text { Demonstratie van } \\
\text { autonome en } \\
\text { adviessystemen } \\
\text { systemen. }\end{array}$ & $\begin{array}{l}\text { Onderzoek naar } \\
\text { ongelukken en bijna- } \\
\text { ongelukken (o.a. big } \\
\text { data). } \\
\text { Digital Twins van } \\
\text { bestaande schepen. }\end{array}$ \\
\hline
\end{tabular}

\section{Kennis en innovatieopgaven}

\begin{tabular}{|c|c|c|c|c|}
\hline $\begin{array}{l}\text { Deel- } \\
\text { programma }\end{array}$ & $\begin{array}{l}\text { Onderzoeksfase TRL } \\
1-3 \\
\text { (NWO, KNAW, EU, } \\
\text { Kennis-basis, } \\
\text { strategische middelen } \\
\text { etc.) }\end{array}$ & $\begin{array}{l}\text { Ontwikkelfase TRL 4-6 } \\
\text { (toegepast onderzoek, } \\
\text { beleidsondersteunend } \\
\text { onderzoek) }\end{array}$ & $\begin{array}{l}\text { Demonstratiefase TRL } \\
\text { 7-9 (MIT, POP, } \\
\text { fieldlabs, etc.) }\end{array}$ & $\begin{array}{l}\text { Implementatiefase } \\
\text { (subsidies, } \\
\text { investeringen, } \\
\text { regelgeving, } \\
\text { kennisverspreiding, } \\
\text { netwerken, } \\
\text { campagnes etc.) }\end{array}$ \\
\hline \multicolumn{5}{|c|}{$\begin{array}{l}\text { Deelprogramma 1: Monitoring, modellering, data- en informatieman } \\
\text { medegebruik binnen de draagkracht van het Noordzee ecosysteem }\end{array}$} \\
\hline $\begin{array}{l}\text { Robuuste } \\
\text { basiskennis } \\
\text { fysisch, } \\
\text { chemisch en } \\
\text { ecologisch } \\
\text { systeem } \\
\text { Noordzee }\end{array}$ & $\begin{array}{l}\text { Evaluatie van de } \\
\text { bestaande gegevens en } \\
\text { monitoringsprogramma's } \\
\text { en advies over "must- } \\
\text { have's en 'nice to } \\
\text { have's" en aanpak } \\
\text { herziening (inclusief } \\
\text { dataportal). } \\
\text { Ontwikkelen van kennis } \\
\text { (modellen) over de } \\
\text { omvang van 'zog- } \\
\text { effecten' van wind op }\end{array}$ & $\begin{array}{l}\text { Ontwikkeling van een } \\
\text { integraal monitoring- } \\
\text { programma en data } \\
\text { portal. }\end{array}$ & $\begin{array}{l}\text { Uitvoeren van een } \\
\text { aantal proeven waarbij } \\
\text { verzameling van } \\
\text { gegevens uit } \\
\text { verschillende } \\
\text { programma's binnen één } \\
\text { monitoringsactiviteit } \\
\text { wordt uitgevoerd. }\end{array}$ & $\begin{array}{l}\text { Hoe organiseren we een } \\
\text { integrale inrichting en } \\
\text { coördinatie van lopende } \\
\text { en nieuwe } \\
\text { monitoringsprogramma's } \\
\text { vanuit de verschillende } \\
\text { betrokken ministeries en } \\
\text { kennisinstellingen? } \\
\text { Hoe en waar kunnen } \\
\text { geschikte } \\
\text { referentiegebieden } \\
\text { worden ingericht? }\end{array}$ \\
\hline
\end{tabular}




\begin{tabular}{|c|c|c|c|c|}
\hline $\begin{array}{l}\text { Deel- } \\
\text { programma }\end{array}$ & $\begin{array}{l}\text { Onderzoeksfase TRL } \\
\text { 1-3 } \\
\text { (NWO, KNAW, EU, } \\
\text { Kennis-basis, } \\
\text { strategische middelen } \\
\text { etc.) }\end{array}$ & $\begin{array}{l}\text { Ontwikkelfase TRL 4-6 } \\
\text { (toegepast onderzoek, } \\
\text { beleidsondersteunend } \\
\text { onderzoek) }\end{array}$ & $\begin{array}{l}\text { Demonstratiefase TRL } \\
\text { 7-9 (MIT, POP, } \\
\text { fieldlabs, etc.) }\end{array}$ & $\begin{array}{l}\text { Implementatiefase } \\
\text { (subsidies, } \\
\text { investeringen, } \\
\text { regelgeving, } \\
\text { kennisverspreiding, } \\
\text { netwerken, } \\
\text { campagnes etc.) }\end{array}$ \\
\hline & $\begin{array}{l}\text { zee en stratificatie- } \\
\text { effecten en hoe deze } \\
\text { doorwerken op het } \\
\text { ecosysteem. } \\
\text { Versterken van de } \\
\text { kennisbasis over de } \\
\text { gevolgen van } \\
\text { klimaatverandering voor } \\
\text { de zeespiegelstijging in } \\
2100 \text { (inzet Noordzee } \\
\text { hulpbronnen voor } \\
\text { kustverdediging) en het } \\
\text { ecosysteem } \\
\text { (natuurwaarden, } \\
\text { effecten op en } \\
\text { mogelijkheden voor } \\
\text { visserij, en } \\
\text { mogelijkheden } \\
\text { maricultuur). }\end{array}$ & & & \\
\hline $\begin{array}{l}\text { Monitorings- } \\
\text { en data } \\
\text { science } \\
\text { technieken } \\
\text { van de } \\
\text { toekomst. }\end{array}$ & $\begin{array}{l}\text { Ontwikkelen van } \\
\text { fundamentele en } \\
\text { toegepaste kennis over } \\
\text { inzet van innovatie } \\
\text { (remote) } \\
\text { monitoringstechnieken } \\
\text { en hun praktische } \\
\text { toepasbaarheid in de } \\
\text { condities op en in de } \\
\text { Noordzee (bijv. DNA- } \\
\text { technieken, akoestiek, } \\
\text { cameratechnieken, } \\
\text { drones). }\end{array}$ & $\begin{array}{l}\text { Ontwikkelen van nieuwe } \\
\text { monitoringstechnieken } \\
\text { voor verzamelen van } \\
\text { basisgegevens over } \\
\text { fysisch, chemisch en } \\
\text { ecologisch ecosysteem. } \\
\text { Ontwikkelen van nieuwe } \\
\text { dataopslag, -verspreiding } \\
\text { technieken (data science) } \\
\text { volgens Europese kennis- } \\
\text { en datastandaarden (bijv. } \\
\text { EMODNET). } \\
\text { Ontwikkelen van nieuwe } \\
\text { technieken voor } \\
\text { effectmetingen van } \\
\text { menselijke ingrepen. }\end{array}$ & $\begin{array}{l}\text { Praktijk klaar maken van } \\
\text { nieuwe monitorings- en } \\
\text { data science technieken. }\end{array}$ & $\begin{array}{l}\text { Hoe brengen we } \\
\text { succesvolle nieuwe } \\
\text { monitoringtechnieken } \\
\text { binnen bestaande } \\
\text { monitoringsprogramma's } \\
\text { (financiering, } \\
\text { onderbreking langjarige } \\
\text { tijdsreeksen)? }\end{array}$ \\
\hline $\begin{array}{l}\text { Afwegingskade } \\
\text { rs duurzaam } \\
\text { gebruik } \\
\text { Noordzee. }\end{array}$ & $\begin{array}{l}\text { Kennisontwikkeling over } \\
\text { rol van natuurlijk } \\
\text { kapitaalrekeningen bij } \\
\text { monetarisering van } \\
\text { ecosysteemdiensten en } \\
\text {-goederen. } \\
\text { Ontwikkeling van } \\
\text { risicobeoordeling van } \\
\text { cumulatieve effecten } \\
\text { van menselijk gebruik. }\end{array}$ & $\begin{array}{l}\text { Ontwikkelen van een } \\
\text { integraal afwegingskader } \\
\text { inpassing van menselijke } \\
\text { ingrepen en activiteiten } \\
\text { binnen de grenzen van de } \\
\text { draagkracht van het } \\
\text { Noordzee ecosysteem. }\end{array}$ & & $\begin{array}{l}\text { Hoe zorgen we voor } \\
\text { internationale } \\
\text { afstemming en } \\
\text { ontwikkeling } \\
\text { afwegingskaders } \\
\text { energietransitie op zee } \\
\text { in relatie tot } \\
\text { systeemdraagkracht? } \\
\text { Dienen, in de context } \\
\text { van een veranderende } \\
\text { Noordzee (klimaat, } \\
\text { energietransitie), de } \\
\text { huidige (internationale) } \\
\text { beleidsdoelen voor } \\
\text { natuur, visserij en ander }\end{array}$ \\
\hline
\end{tabular}




\begin{tabular}{|c|c|c|c|c|}
\hline $\begin{array}{l}\text { Deel- } \\
\text { programma }\end{array}$ & $\begin{array}{l}\text { Onderzoeksfase TRL } \\
1-3 \\
\text { (NWO, KNAW, EU, } \\
\text { Kennis-basis, } \\
\text { strategische middelen } \\
\text { etc.) }\end{array}$ & $\begin{array}{l}\text { Ontwikkelfase TRL 4-6 } \\
\text { (toegepast onderzoek, } \\
\text { beleidsondersteunend } \\
\text { onderzoek) }\end{array}$ & $\begin{array}{l}\text { Demonstratiefase TRL } \\
\text { 7-9 (MIT, POP, } \\
\text { fieldlabs, etc.) }\end{array}$ & $\begin{array}{l}\text { Implementatiefase } \\
\text { (subsidies, } \\
\text { investeringen, } \\
\text { regelgeving, } \\
\text { kennisverspreiding, } \\
\text { netwerken, } \\
\text { campagnes etc.) }\end{array}$ \\
\hline & & & & $\begin{array}{l}\text { gebruik te moeten } \\
\text { worden bijgesteld? }\end{array}$ \\
\hline \multicolumn{5}{|c|}{$\begin{array}{l}\text { Deelprogramma 2: Natuurvriendelijke aanleg van grootschalige bouwwerken voor energieproductie en stimulering } \\
\text { van natuur hierbinnen }\end{array}$} \\
\hline $\begin{array}{l}\text { Natuurinclusief } \\
\text { bouwen. }\end{array}$ & $\begin{array}{l}\text { Kennisontwikkeling over } \\
\text { de kosten en baten van } \\
\text { natuurinclusief bouwen. } \\
\text { Ontwikkeling van } \\
\text { methoden en technieken } \\
\text { om aanleg van } \\
\text { bouwwerken op zee met } \\
\text { zo min mogelijk impact } \\
\text { te laten plaatsvinden } \\
\text { (o.a. onderwatergeluid, } \\
\text { en effecten op vis, } \\
\text { vogels, vleermuizen, } \\
\text { zeezoogdieren). } \\
\text { Versterking van de } \\
\text { kennis over welke } \\
\text { ontwerpen en materialen } \\
\text { natuurontwikkeling rond } \\
\text { bouwwerken op zee te } \\
\text { bevorderen } \\
\text { (gemeenschappen die } \\
\text { gedijen op hard } \\
\text { substraat, habitats voor } \\
\text { vis, schaal- en } \\
\text { schelpdieren). } \\
\text { Kennisontwikkeling over } \\
\text { aantrekkende werking } \\
\text { van natuurinclusieve } \\
\text { bouwwerken op zee op } \\
\text { zeevogels (en daarmee } \\
\text { gepaard gaande risico's } \\
\text { en mitigatie). }\end{array}$ & $\begin{array}{l}\text { Ontwikkeling van } \\
\text { methoden en technieken } \\
\text { om aanleg met zo min } \\
\text { mogelijk impact te laten } \\
\text { plaatsvinden (o.a. } \\
\text { onderwatergeluid). } \\
\text { Ontwikkeling van } \\
\text { methoden en technieken } \\
\text { om met aanleg } \\
\text { natuurontwikkeling te } \\
\text { stimuleren. }\end{array}$ & Uitvoeren van pilots. & $\begin{array}{l}\text { Met welke } \\
\text { sturingsinstrumenten } \\
\text { kan natuurinclusief } \\
\text { bouwen actief } \\
\text { gestimuleerd worden? } \\
\text { Welke compenserende } \\
\text { maatregelen kunnen } \\
\text { worden genomen in } \\
\text { geval van negatieve } \\
\text { effecten van } \\
\text { energiewinning op de } \\
\text { natuur in de Noordzee? } \\
\text { Hoe zorgen we ervoor } \\
\text { dat kennis over effecten } \\
\text { op natuur en } \\
\text { natuurinclusief bouwen } \\
\text { die beschikbaar is bij de } \\
\text { windenergiebedrijven } \\
\text { (eigen monitoring) } \\
\text { beschikbaar komt in het } \\
\text { publieke domein? } \\
\text { Hoe gaan we in de } \\
\text { toekomst om met de } \\
\text { (verplichte) } \\
\text { ontmanteling van } \\
\text { natuurinclusief } \\
\text { aangelegde offshore } \\
\text { installaties als zich daar } \\
\text { natuurwaarden op } \\
\text { ontwikkeld hebben? }\end{array}$ \\
\hline $\begin{array}{l}\text { Natuurontwikk } \\
\text { eling } \\
\text { stimuleren. }\end{array}$ & $\begin{array}{l}\text { Versterking van de } \\
\text { kennis over welke } \\
\text { ontwerpen en materialen } \\
\text { natuurontwikkeling rond } \\
\text { bouwwerken op zee te } \\
\text { bevorderen } \\
\text { (gemeenschappen die } \\
\text { gedijen op hard } \\
\text { substraat, habitats voor } \\
\text { vis, schaal- en } \\
\text { schelpdieren). }\end{array}$ & $\begin{array}{l}\text { Ontwikkeling van } \\
\text { methoden en technieken } \\
\text { om met aanleg } \\
\text { natuurontwikkeling te } \\
\text { stimuleren. }\end{array}$ & Uitvoering van pilots. & $\begin{array}{l}\text { Aan welke } \\
\text { kwaliteitseisen moet } \\
\text { nieuwe natuur voldoen? } \\
\text { Hoe gaan we om met } \\
\text { nieuw gecreëerde natuur } \\
\text { in relatie tot het } \\
\text { ontmantelen van } \\
\text { installaties? } \\
\text { Hoe zorgen we ervoor } \\
\text { dat kennis over pilots } \\
\text { rond het stimuleren van } \\
\text { natuurontwikkeling die } \\
\text { beschikbaar is bij de } \\
\text { initiatiefnemers, }\end{array}$ \\
\hline
\end{tabular}




\begin{tabular}{|c|c|c|c|c|}
\hline $\begin{array}{l}\text { Deel- } \\
\text { programma }\end{array}$ & $\begin{array}{l}\text { Onderzoeksfase TRL } \\
\text { 1-3 } \\
\text { (NWO, KNAW, EU, } \\
\text { Kennis-basis, } \\
\text { strategische middelen } \\
\text { etc.) }\end{array}$ & $\begin{array}{l}\text { Ontwikkelfase TRL 4-6 } \\
\text { (toegepast onderzoek, } \\
\text { beleidsondersteunend } \\
\text { onderzoek) }\end{array}$ & $\begin{array}{l}\text { Demonstratiefase TRL } \\
\text { 7-9 (MIT, POP, } \\
\text { fieldlabs, etc.) }\end{array}$ & $\begin{array}{l}\text { Implementatiefase } \\
\text { (subsidies, } \\
\text { investeringen, } \\
\text { regelgeving, } \\
\text { kennisverspreiding, } \\
\text { netwerken, } \\
\text { campagnes etc.) }\end{array}$ \\
\hline & & & & $\begin{array}{l}\text { beschikbaar komt in het } \\
\text { publieke domein? }\end{array}$ \\
\hline \multicolumn{5}{|c|}{$\begin{array}{l}\text { Deelprogramma 3: Meervoudig ruimtegebruik door combinaties van energie infrastructuur met voedselproductie } \\
\text { (visserij en maricultuur) }\end{array}$} \\
\hline $\begin{array}{l}\text { Meervoudig } \\
\text { ruimtegebruik: } \\
\text { algemeen. }\end{array}$ & $\begin{array}{l}\text { Kennisontwikkeling over } \\
\text { kosten en baten van } \\
\text { meervoudig } \\
\text { ruimtegebruik op de } \\
\text { Noordzee. } \\
\text { Kennisontwikkeling over } \\
\text { de technische en } \\
\text { ecologische kosten en } \\
\text { baten van } \\
\text { waterstofopslag. }\end{array}$ & $\begin{array}{l}\text { Verdere ontwikkeling van } \\
\text { kansenkaarten voor } \\
\text { meervoudig } \\
\text { ruimtegebruik. } \\
\text { Ontwerp van windparken } \\
\text { op een dusdanige manier } \\
\text { dat maricultuur en visserij } \\
\text { hierbinnen kunnen worden } \\
\text { ingepast vanuit het } \\
\text { perspectief van efficiënt } \\
\text { ruimtegebruik voor } \\
\text { iedereen, duurzame } \\
\text { productie en veiligheid } \\
\text { (bijv. een 'visstraat' voor } \\
\text { sleepnetvissers) }\end{array}$ & Uitvoering van pilots. & $\begin{array}{l}\text { Welke kennis- en } \\
\text { competenties hebben de } \\
\text { toekomstige } \\
\text { werknemers op de } \\
\text { offshore, visserij en } \\
\text { maricultuur } \\
\text { arbeidsmarkt nodig? } \\
\text { Faciliterend (en meer } \\
\text { dwingend) beleid voor } \\
\text { meervoudig } \\
\text { ruimtegebruik. }\end{array}$ \\
\hline $\begin{array}{l}\text { Meervoudig } \\
\text { ruimtegebruik: } \\
\text { combineren } \\
\text { (wind)energie } \\
\text { en visserij. }\end{array}$ & Zie MMIP Visserij. & Zie MMIP Visserij. & Zie MMIP Visserij. & Zie MMIP Visserij. \\
\hline $\begin{array}{l}\text { Meervoudig } \\
\text { ruimtegebruik: } \\
\text { combineren } \\
\text { (wind)energie } \\
\text { en } \\
\text { maricultuur. }\end{array}$ & $\begin{array}{l}\text { Fundamentele } \\
\text { kennisontwikkeling over } \\
\text { toepassingsmogelijkhed } \\
\text { en van Integrated Multi- } \\
\text { Trophic Aquaculture } \\
\text { (IMTA) op de Noordzee. } \\
\text { Ontwerp en ontwikkeling } \\
\text { van 'Noordzee-proof' } \\
\text { productie-installaties } \\
\text { voor maricultuur. } \\
\text { Zie MMIP } \\
\text { Biogrondstoffen } \\
\text { (onderdeel Zeewier). }\end{array}$ & $\begin{array}{l}\text { Toegepaste } \\
\text { kennisontwikkeling voor } \\
\text { IMTA op de Noordzee. } \\
\text { Praktijktesten van } \\
\text { ontwikkelde offshore } \\
\text { maricultuur productie- } \\
\text { installaties. } \\
\text { Zie MMIP Biogrondstoffen } \\
\text { (onderdeel Zeewier).. }\end{array}$ & $\begin{array}{l}\text { Uitvoeren van IMTA- } \\
\text { pilots. } \\
\text { Zie MMIP } \\
\text { Biogrondstoffen } \\
\text { (onderdeel Zeewier). }\end{array}$ & $\begin{array}{l}\text { Zie MMIP } \\
\text { Biogrondstoffen } \\
\text { (onderdeel Zeewier) }\end{array}$ \\
\hline \multicolumn{5}{|c|}{ Deelprogramma 4: Vermindering van afval in zee } \\
\hline $\begin{array}{l}\text { Minder afval in } \\
\text { zee. }\end{array}$ & $\begin{array}{l}\text { Kennisontwikkeling over } \\
\text { welk afval door } \\
\text { productie en consumptie } \\
\text { van voeding en } \\
\text { consumptiegoederen in } \\
\text { het algemeen positief } \\
\text { beïnvloedbaar is en hoe } \\
\text { dit te doen. } \\
\text { Kennisontwikkeling over } \\
\text { welk afval aan boord } \\
\text { van schepen in het }\end{array}$ & $\begin{array}{l}\text { Ontwikkeling van } \\
\text { strategieën (inclusief } \\
\text { prikkels) om } \\
\text { gedragsverandering rond } \\
\text { afval in zee (scheepvaart) } \\
\text { of vanaf het land } \\
\text { (consument) te } \\
\text { bewerkstelligen. } \\
\text { Ontwikkelen van } \\
\text { makkelijke en in de } \\
\text { praktijk werkende }\end{array}$ & $\begin{array}{l}\text { Toekomstbestendig } \\
\text { maken van het } \\
\text { bestaande KIMO 'Fishing } \\
\text { for Litter' project van de } \\
\text { Nederlandse vissersvloot } \\
\text { (uitbreiding, financieel). } \\
\text { Pilots aan boord van } \\
\text { schepen rond praktisch } \\
\text { werkende } \\
\text { afvalinzamelingssysteme } \\
\mathrm{n} \text {. }\end{array}$ & $\begin{array}{l}\text { Hoe kunnen we } \\
\text { verbindingen leggen } \\
\text { tussen zwerfafval op } \\
\text { land en de rivieren en } \\
\text { afval in zee? } \\
\text { Hoe kunnen de havens } \\
\text { worden gestimuleerd om } \\
\text { meer makkelijke } \\
\text { afvalinzamelingsvoorzien } \\
\text { ingen aan te leggen? }\end{array}$ \\
\hline
\end{tabular}




\begin{tabular}{|c|c|c|c|c|}
\hline $\begin{array}{l}\text { Deel- } \\
\text { programma }\end{array}$ & $\begin{array}{l}\text { Onderzoeksfase TRL } \\
1-3 \\
\text { (NWO, KNAW, EU, } \\
\text { Kennis-basis, } \\
\text { strategische middelen } \\
\text { etc.) }\end{array}$ & $\begin{array}{l}\text { Ontwikkelfase TRL 4-6 } \\
\text { (toegepast onderzoek, } \\
\text { beleidsondersteunend } \\
\text { onderzoek) }\end{array}$ & $\begin{array}{l}\text { Demonstratiefase TRL } \\
\text { 7-9 (MIT, POP, } \\
\text { fieldlabs, etc.) }\end{array}$ & $\begin{array}{l}\text { Implementatiefase } \\
\text { (subsidies, } \\
\text { investeringen, } \\
\text { regelgeving, } \\
\text { kennisverspreiding, } \\
\text { netwerken, } \\
\text { campagnes etc.) }\end{array}$ \\
\hline & $\begin{array}{l}\text { algemeen positief } \\
\text { beïnvloedbaar is en hoe } \\
\text { dit te doen. } \\
\text { Sociaalwetenschappelijk } \\
\text { onderzoek naar } \\
\text { gedragsverandering en } \\
\text { het organiseren van } \\
\text { marktprikkels. }\end{array}$ & $\begin{array}{l}\text { afvalsystemen aan boord } \\
\text { van schepen. }\end{array}$ & & $\begin{array}{l}\text { Hoe zorgen we ervoor } \\
\text { dat vissers als } \\
\text { inzamelaars van } \\
\text { zwerfafval geen } \\
\text { inkomstenderving } \\
\text { hebben als gevolg van } \\
\text { deze activiteit? }\end{array}$ \\
\hline \multicolumn{5}{|c|}{$\begin{array}{l}\text { Deelprogramma 5: Verhoging van de scheepvaartveiligheid door verbeterde en slimmere schepen en goed } \\
\text { ondersteunde en voorbereide bemanningen. }\end{array}$} \\
\hline $\begin{array}{l}\text { Voorkomen } \\
\text { extreme } \\
\text { bewegingen } \\
\text { en belastingen } \\
\text { voor } \\
\text { bemanning, } \\
\text { passagiers, } \\
\text { lading en schip }\end{array}$ & $\begin{array}{l}\text { Niet-lineaire } \\
\text { hydrodynamica van } \\
\text { schepen in hoge golven } \\
\text { in diep en ondiep water } \\
\text { (inclusief golfklappen). } \\
\text { Resulterende dynamica } \\
\text { van het schip en de } \\
\text { lading (zoals } \\
\text { containers). } \\
\text { Belasting op mensen } \\
\text { aan boord } \\
\text { Ontwikkeling prestatie } \\
\text { criteria voor } \\
\text { bemanningen } \\
\text { Machine Learning } \\
\text { technieken voor } \\
\text { bepaling golven en } \\
\text { scheepsbewegingen }\end{array}$ & $\begin{array}{l}\text { Methoden om extreme } \\
\text { bewegingen te voorkomen } \\
\text { (anti-slingersystemen). } \\
\text { Verbetering } \\
\text { beladingsmethodes (zoals } \\
\text { sjorringen). } \\
\text { Slimme methoden om } \\
\text { belastingen te voorkomen } \\
\text { (golfradar / haptiek/ 'ship } \\
\text { as a wave buoy') }\end{array}$ & $\begin{array}{l}\text { Demonstratie van } \\
\text { nieuwe anti- } \\
\text { slingerconcepten. } \\
\text { Demonstratie nieuwe } \\
\text { methoden zoals } \\
\text { golfradar en haptiek op } \\
\text { snelle schepen. } \\
\text { Voorspelling bewegingen } \\
\text { en inzetbaarheid op } \\
\text { basis van } \\
\text { golfwaarneming. }\end{array}$ & $\begin{array}{l}\text { Toepassing ontwikkelde } \\
\text { (hydro)dynamische } \\
\text { methoden in het } \\
\text { scheepsontwerp. } \\
\text { Toepassing } \\
\text { modelproeven en } \\
\text { simulatietechnieken, bij } \\
\text { voorbeeld in ongevallen } \\
\text { onderzoek. }\end{array}$ \\
\hline $\begin{array}{l}\text { Scheepsstabilit } \\
\text { eit }\end{array}$ & $\begin{array}{l}\text { Onderzoek naar extreme } \\
\text { dynamische } \\
\text { slingerhoeken die } \\
\text { kunnen optreden. } \\
\text { Onderzoek naar } \\
\text { methoden voor het } \\
\text { voorspelling van intacte- } \\
\text { en lekstabiliteit en } \\
\text { verbetering } \\
\text { scheepsontwerp. }\end{array}$ & $\begin{array}{l}\text { Ontwikkeling van } \\
\text { methoden om kapseizen } \\
\text { van beschadigde schepen } \\
\text { te voorkomen, zoals } \\
\text { Emergency Floatation \& } \\
\text { Stability Devices (EFSD's). } \\
\text { Ontwikkelen advies } \\
\text { systemen voor voorkomen } \\
\text { extreme } \\
\text { slingerbewegingen. }\end{array}$ & $\begin{array}{l}\text { Eerste modelproeven en } \\
\text { studies met EFSD's door } \\
\text { MARIN, TU Delft en } \\
\text { SARC. } \\
\text { Inzet simulatoren in } \\
\text { strijd tegen kapseizen } \\
\text { en zinken van schepen. }\end{array}$ & $\begin{array}{l}\text { Toepassing } \\
\text { modelproeven en } \\
\text { simulatietechnieken } \\
\text { (desktop / brug- } \\
\text { simulator / } \\
\text { rekencluster), bij } \\
\text { voorbeeld in ongevallen } \\
\text { onderzoek. }\end{array}$ \\
\hline $\begin{array}{l}\text { Aanvaringsrisi } \\
\text { co met } \\
\text { schepen en } \\
\text { constructies } \\
\text { (kans en } \\
\text { consequentie) }\end{array}$ & $\begin{array}{l}\text { Onderzoek naar } \\
\text { verkeersveiligheid, bij } \\
\text { voorbeeld met behulp } \\
\text { van AIS (Automatic } \\
\text { Identification System) } \\
\text { data. } \\
\text { Ontwikkeling van } \\
\text { nauwkeurige } \\
\text { manoeuvreermodellen in } \\
\text { diep en ondiep water. }\end{array}$ & $\begin{array}{l}\text { Ontwikkeling van } \\
\text { voorspellende modellen } \\
\text { voor de kans op aanvaring } \\
\text { en de gevolgen daarvan. } \\
\text { Implementatie } \\
\text { manoeuvreermodellen in } \\
\text { simulatoren. } \\
\text { Onderzoek naar } \\
\text { adviessystemen om } \\
\text { aanvaringsrisico's te } \\
\text { voorkomen }\end{array}$ & $\begin{array}{l}\text { Toepassing van deze } \\
\text { modellen voor vragen } \\
\text { rond toekomstige } \\
\text { ontwikkelingen, zoals } \\
\text { toename } \\
\text { scheepvaartverkeer en } \\
\text { Wind op Zee (aanvaring } \\
\text { schepen onderling en } \\
\text { met andere constructies } \\
\text { zoals windturbines). }\end{array}$ & $\begin{array}{l}\text { Verkeerstudies naar } \\
\text { effecten van } \\
\text { gecombineerde } \\
\text { bemande en autonome } \\
\text { schepen, zowel op zee } \\
\text { als ook de } \\
\text { binnenwateren en } \\
\text { havens. }\end{array}$ \\
\hline
\end{tabular}




\begin{tabular}{|c|c|c|c|c|}
\hline $\begin{array}{l}\text { Deel- } \\
\text { programma }\end{array}$ & $\begin{array}{l}\text { Onderzoeksfase TRL } \\
\text { 1-3 } \\
\text { (NWO, KNAW, EU, } \\
\text { Kennis-basis, } \\
\text { strategische middelen } \\
\text { etc.) }\end{array}$ & $\begin{array}{l}\text { Ontwikkelfase TRL 4-6 } \\
\text { (toegepast onderzoek, } \\
\text { beleidsondersteunend } \\
\text { onderzoek) }\end{array}$ & $\begin{array}{l}\text { Demonstratiefase TRL } \\
\text { 7-9 (MIT, POP, } \\
\text { fieldlabs, etc.) }\end{array}$ & $\begin{array}{l}\text { Implementatiefase } \\
\text { (subsidies, } \\
\text { investeringen, } \\
\text { regelgeving, } \\
\text { kennisverspreiding, } \\
\text { netwerken, } \\
\text { campagnes etc.) }\end{array}$ \\
\hline & $\begin{array}{l}\text { Onderzoek naar de } \\
\text { faalkansen bij aanvaring } \\
\text { en de gevolgen daarvan } \\
\text { (omvang schade). }\end{array}$ & & & \\
\hline $\begin{array}{l}\text { Human factors } \\
\text { en inzet } \\
\text { Virtual / } \\
\text { Augmented } \\
\text { Reality }\end{array}$ & $\begin{array}{l}\text { Onderzoek naar } \\
\text { menselijke factoren bij } \\
\text { veiligheid op zee. } \\
\text { Onderzoek naar nieuwe } \\
\text { simulatiemethoden die } \\
\text { noodzakelijk zijn om } \\
\text { mensen goed te trainen. } \\
\text { Meetbaar maken van de } \\
\text { menselijke factor en de } \\
\text { prestaties van de } \\
\text { bemanning. }\end{array}$ & $\begin{array}{l}\text { Ontwikkeling van } \\
\text { simulatoren en Virtual } \\
\text { Reality technieken voor } \\
\text { het trainen en } \\
\text { voorbereiden van } \\
\text { bemanningen en loodsen } \\
\text { (en inzet meettechnieken } \\
\text { menselijke factoren). }\end{array}$ & $\begin{array}{l}\text { Inzet van simulator- en } \\
\text { VR technieken voor het } \\
\text { overbruggen van het gat } \\
\text { tussen ontwerp en } \\
\text { operatie: nieuwe } \\
\text { schepen ervaren voordat } \\
\text { ze gebouwd zijn. }\end{array}$ & $\begin{array}{l}\text { Inzet van simulatie- en } \\
\text { VR technieken voor het } \\
\text { trainen en voorbereiden } \\
\text { van bemanningen en } \\
\text { loodsen en de } \\
\text { ontwikkeling van nieuwe } \\
\text { infrastructuur. }\end{array}$ \\
\hline $\begin{array}{l}\text { Veiligheid bij } \\
\text { autonome } \\
\text { schepen }\end{array}$ & $\begin{array}{l}\text { Onderzoeken naar } \\
\text { Situational Awareness } \\
\text { en de daarbij horende } \\
\text { sensor systemen. } \\
\text { Onderzoek naar Collision } \\
\text { Avoidance methoden. } \\
\text { Onderzoek naar } \\
\text { zelflerende, adaptieve } \\
\text { simulatie modellen door } \\
\text { toepassing van } \\
\text { Kunstmatige } \\
\text { Intelligentie. }\end{array}$ & $\begin{array}{l}\text { Ontwikkeling van Manning } \\
\& \text { Automation systemen. } \\
\text { Ontwikkel geïntegreerde } \\
\text { omgeving om informatie } \\
\text { behoefte, rollen, } \\
\text { communicatie te } \\
\text { onderzoeken }\end{array}$ & $\begin{array}{l}\text { Eerste proefprojecten } \\
\text { van autonoom varen } \\
\text { schepen in havens, op } \\
\text { vaarwegen en op zee. } \\
\text { Ontwikkeling eerste } \\
\text { Digital Twins van } \\
\text { schepen. }\end{array}$ & $\begin{array}{l}\text { Eerste pilotprojecten } \\
\text { autonoom varen en } \\
\text { Digital Twins. } \\
\text { Het verifiëren en } \\
\text { beoordelen van } \\
\text { autonome systemen } \\
\text { door middel van } \\
\text { simulatie technieken. }\end{array}$ \\
\hline $\begin{array}{l}\text { Inzet van } \\
\text { advies } \\
\text { systemen } \\
\text { onshore \& } \\
\text { onboard }\end{array}$ & $\begin{array}{l}\text { Onderzoek } \\
\text { informatiebehoefte en } \\
\text { presentatie aan boord } \\
\text { en bij remote monitoring } \\
\text { van bemande schepen. } \\
\text { Onderzoek simulatie } \\
\text { technieken in combinatie } \\
\text { met machine learning } \\
\text { als instrument om } \\
\text { decision support te } \\
\text { geven. }\end{array}$ & $\begin{array}{l}\text { Ontwikkeling van } \\
\text { adviessystemen voor het } \\
\text { scheepsgedrag in extreme } \\
\text { omstandigheden } \\
\text { (combinatie } \\
\text { omgevingscondities en } \\
\text { scheepsgedrag). }\end{array}$ & $\begin{array}{l}\text { Ontwikkel simulatie } \\
\text { technieken om decision } \\
\text { support systemen te } \\
\text { optimaliseren, } \\
\text { verifiëren, valideren en } \\
\text { testen (inclusief de } \\
\text { Human Factor). }\end{array}$ & $\begin{array}{l}\text { Het verifiëren van de } \\
\text { effectiviteit van advies } \\
\text { systemen met de } \\
\text { 'operator in the loop'. }\end{array}$ \\
\hline
\end{tabular}

\section{Positionering MMIP}

Dit MMIP heeft interacties met de twee klimaattafels Industrie, en Landbouw \& Landgebruik; de zeven Topsectoren Energie, Agri \& Food, Water \& Maritiem, Logistiek, Life Sciences \& Health, Chemie, en High Tech Systemen en Materialen; en de drie Sleuteltechnologieën ICT, Geavanceerde Fabricageprocessen, en Meet- en Detectietechnologie. Het heeft (deels) overlap met Missie B Klimaatneutrale Landbouw en voedselproductie en met Missie D Gewaardeerd, Gezond en Veilig Voedsel.

Het onderwerp Noordzee heeft grote raakvlakken met MMIPs die door andere topsectoren worden opgesteld; o.a. MMIP Wind op Zee van de Topsector Energie, en vier MMIPs van de Topsector 
Maritiem, te weten: Towards Zero Emissions, Blue Growth, Digital \& Autonomous Shipping, en Safety \& Security). Er kan veel synergie bereikt worden door onderlinge afstemming en gezamenlijke aanpak van de kennis- en innovatieopgaves rond de Noordzee die bij de verschillende topsectoren zijn ondergebracht.

Sterktes en zwaktes kennispositie en positie bedrijfsleven

De offshore-industrie en de windenergiesector kenmerken zich door een sterk innovatief en vaak internationaal karakter en financiële slagkracht. Andere delen van de blauwe energiesector, zoals zonne- en getijdenenergie, zijn nog in een opstartfase en hebben veel ideeën maar weinig financiële middelen. De windenergiesector ziet zich geconfronteerd met een toenemende maatschappelijke vraag rond het combineren van de door hen ingenomen ruimte met natuur en andere gebruikers. Waar dit in de oude kavelbesluiten niet actief werd gestimuleerd, komt daar in de toekomst verandering in. De sector ziet risico's rond veiligheid en andere negatieve interacties door medegebruik, wat (tot nu toe) geresulteerd heeft in een afwachtende houding, zeker als het gaat om pilots rond visserij en maricultuur; op het gebied van natuurontwikkeling (o.a. aanleg oesterbanken en habitats voor vissen en schaaldieren) komt nu beweging.

De sectoren visserij en maricultuur staan beschreven in respectievelijk het MMIP Visserij en het MMIP Biogrondstoffen.

\section{Samenhang met (bestaande) nationale en internationale agenda's}

- Europese Kaderrichtlijn Mariene Strategie (KRM);

- $\quad$ Europese vogel- en Habitatrichtlijnen (Natura2000);

- Europees Gemeenschappelijk Visserij Beleid (GVB);

- Strategische Agenda Noordzee 2030 en het daaraan gekoppelde traject rond het Noordzee Akkoord door het Overlegorgaan Fysieke Leefomgeving (OFL);

- $\quad$ Europese Blue Growth Strategie 2020;

- Rijksbrede Maritieme Strategie 2015-2025 met bijbehorende werkprogramma's.

\section{Strategie internationaal}

De belangrijkste internationale strategie die relevant is voor dit MMIP is de Europese Blue Growth Strategy 2020, als onderdeel van de Europese strategie voor slimme, duurzame en inclusieve blauwe groei. Daarnaast zijn er diverse Europese richtlijnen die de kaders stellen voor medegebruik van het Noordzee ecosysteem, waaronder verplichtingen voor natuurbescherming (inclusief het aanwijzen van beschermde gebieden) en de duurzame exploitatie van visbestanden. Voor de exploitatie van wind is er geen Europese strategie of regelgeving, met dien verstande dat de aanleg van windparken (en andere vormen van energie- en grondstoffenwinning) moeten voldoen aan de Natura2000 regelgeving.

In Nederland wordt vanuit het OFL gewerkt aan het Noordzee Akkoord, waarbij het vooral gaat om ruimtelijke afspraken over energie, voedsel en natuur op de Noordzee. Dit Noordzee Akkoord moet in de zomer dit jaar gereed zijn. De uitkomsten hiervan hebben mogelijk gevolgen voor de focus van het voorliggende MMIP en de daaraan gekoppelde MMIPs voor Visserij en voor Biogrondstoffen.

In samenwerking met de maritieme sector ontwikkelde de rijksbrede overheid 'De Nederlandse Maritieme Strategie 2015-2025'. Deze heeft als ambitie: 'een internationale duurzame toppositie van Nederland door integrale samenwerking tussen Rijksoverheid en maritieme cluster'. Op het vlak van veiligheid en milieu stelt de Maritieme Strategie: "Alleen een veilig, milieuvriendelijk en duurzaam opererend maritiem cluster kan zijn economische potentie blijvend waarmaken. Een schone zee- en binnenvaart dragen bij aan de verbetering van het leefklimaat voor omwonenden van havens en aan de ontwikkelruimte voor diezelfde havens. Onverminderde inzet door overheid en bedrijfsleven voor een veilige, milieuvriendelijke en duurzame ontwikkeling van de scheepvaart, zowel in nationaal als in internationaal verband, is daarom noodzakelijk." 


\section{Innovatiesysteem en consortiumvorming}

Publiek-private samenwerking (PPS) staat nog in de kinderschoenen als het gaat om meervoudig ruimtegebruik voor natuurontwikkeling en/of voedselproductie. De pilot-initiatieven van natuurorganisaties rond het herstel van platte oesterbanken worden deels samen met energiebedrijven uitgevoerd, maar worden over het algemeen gefinancierd door charitatieve middelen en niet via topsectorfinanciering. De visserijsector is pas recent onderdeel geworden van gericht topsectorenbeleid (Agri \& Food). De visserij- en de maricultuursector kenmerken zich door een gefragmenteerde organisatiegraad en weinig financiële slagkracht, wat deelname aan consortia en bijeenbrengen van cofinanciering bemoeilijkt.

Er moet een brede samenwerking van partijen ontstaan met een hogere organisatiegraad om optimale systemen voor medegebruik van grootschalige bouwwerken te realiseren. Startups, die bijvoorbeeld specifiek inzetten op medegebruik van windparken voor voedselproductie, gaan een grote rol spelen. Het is daarom belangrijk om financiële stimuli en vangnetten voor kansrijke ontwikkelingen te stimuleren.

Voor de intensivering van menselijk medegebruik is een verbetering van de kennisbasis over de randvoorwaarden waarbinnen dit gebruik kan plaatsvinden essentieel. Hiervoor is een integrale en gecoördineerde aanpak (in tegenstelling tot de huidige sectorale en gefragmenteerde aanpak) vanuit de betrokken ministeries nodig.

Het doel op het vlak van scheepsvaartveiligheid is om bij een toenemende zeescheepvaart en toenemende ruimtelijke ontwikkelingen op de Noordzee (denk aan wind op zee) het veiligheidsniveau minimaal op hetzelfde niveau te handhaven en waar mogelijk te verbeteren. 


\title{
Bijlage 13 MMIP Visserij
}

\author{
MMIP Duurzame en veilige Noordzee, oceanen en binnenwateren - Versie 1 juni 2019 \\ Missie E: Subthema 5: Visserij
}

\section{Samenvatting}

Het MMIP Visserij richt zich op het ontwikkelen van een ecologisch én socio-economisch duurzame kusten zeevisserij op de Noordzee ter bevordering van een dynamische visserijsector, een goede levensstandaard voor visserijgemeenschappen en een goede status van de visbestanden en het mariene milieu. Dit MMIP vormt, samen met de apart uitgewerkte MMIPs 'Duurzame en veilige Noordzee' (Missie E) en 'Biogrondstoffen' (incl. zeewier) (Missie B) een integraal geheel.

Het MMIP Visserij volgt inhoudelijk de ambitie, en de kennis- en innovatieopgave uit Missie $\mathrm{E}$ van het ministerie van LNV. De daarin genoemde onderwerpen worden hier als deelthema behandeld en zijn gebruikt om kennis- en innovatievragen op te halen bij belanghebbenden via een online enquête en een aantal interviews. Ook is de Kennisagenda Noordzee 2030 geraadpleegd. In een tweetal workshops zijn prioriteiten geïdentificeerd. De prioritaire kennis- en innovatievragen zijn hieronder per deelthema weergeven:

\section{Versterken van het beheer van de visbestanden}

Kennisontwikkeling van (gegevensarme) visbestanden en hun verspreiding; financiering en maatregelen om nieuwe visstand-onderzoektechnieken standaard onderdeel te maken van het visserijonderzoek; onderzoek naar de effecten van de aanlandplicht.

2. Verminderen van emissies

Onderzoek gericht op scheepsinnovatie, vloottransitie en duurzamere voortstuwingssystemen gericht op efficiëntieverbetering.

3. Verbeteren van arbeidsomstandigheden

Optimaliseren en innoveren van het visproces (minder handelingen, meer geautomatiseerd) en inzicht in inzet buitenlandse werknemers.

4. Verbeteren van dierenwelzijn

Systeemanalyse van het vis- en verwerkingsproces t.b.v. dierenwelzijn, inzicht in gedragsverandering bij vissers en mogelijkheden omtrent een dierenwelzijn certificaat.

5. Verminderen van bodemberoering

Innoveren t.b.v. minder bodemberoering; creëren van ruimte (financieel, regelgeving) om te kunnen innoveren; het creëren van draagvlak (lokaal, nationaal, Europees) voor nieuwe vistechnieken; inzicht in de benodigde controle \& handhaving maatregelen. Vaststellen van ecologische en socio-economische effecten nieuwe vistechnieken. Kennisontwikkeling van het bodemecosysteem.

6. Verbeteren van selectiviteit

Naast innoveren in selectiviteit ook ruimte creëren (financieel, regelgeving) om te kunnen innoveren, gebruik makend van bestaande faciliteiten ( $v b$. Visserij Innovatie Centrum). Inzicht in de verspreiding van commerciële en niet-commerciële soorten onder invloed van klimaatverandering; Kennisontwikkeling van visgedrag (in relatie tot vistuig alsook verspreiding). Vaststellen van ecologische effecten van nieuwe vistechnieken.

7. Verbeteren van economisch perspectief

Stimuleren van visserijondernemers om te innoveren en het inbedden van duurzaamheid, ecologie en anticiperen op de toekomst in het visserijonderwijs. Toegepaste kennisontwikkeling m.b.t. alternatieve en nieuwe verdienmodellen; inzicht in benodigde toekomstige vaardigheden van vissers. Inzicht in de inpasbaarheid en medegebruik van de visserij op de 'nieuwe' Noordzee; inzicht in hoe kennisontwikkeling (fundamenteel en toegepast) van multi-use schepen, high-tech oplossingen en het uitvoeren van pilots naar alternatieve vistechnieken in windparken hieraan bij kunnen dragen. Vaststellen van socio-economische effecten van nieuwe vistechnieken. 


\section{Systeemveranderingen}

Onderzoek naar andere vormen van visserij en bedrijfsvoering; kennisontwikkeling naar multi-use schepen en high-tech oplossingen t.b.v. kostenbesparing en opbrengstverhoging.

9. Circulaire visserij

Onderzoek, oplossingen en testen van vangstmethoden, verwerkmethoden aan boord, zero brandstof emissies, zero geluid emissies en systeem integratie ('zero impact kotter'); alternatieve opties voor pulsvisserij. Duurzame gesloten kweek van vissoorten voor zowel consumptie als uitzetten in zee (Circulaire viskweek: één vis op je bord en één vis in de zee).

Voor de meeste van deze prioriteiten zijn geen lopende onderzoeksprojecten en zullen nieuwe programma's moeten worden opgezet. Meer informatie in Smith et al. (2019a: Programmeringsstudie Duurzame Visserij; 2019b: Achtergrondrapportage Programmeringsstudie LNV: Noordzee en Visserij, 2019).

\section{Inleiding}

De kust- en zeevisserij in Nederland staat op het moment voor een aantal grote uitdagingen; het verbod op de pulsvisserij, de aanlandplicht, de mogelijke gevolgen van de Brexit alsook het medegebruik op de Noordzee (o.a. energietransitie). Vanuit de Kennis- en Innovatieagenda van het ministerie van Landbouw, Natuur en Voedselkwaliteit is de volgende missie vastgesteld: "Voor de mariene wateren is er in 2030 en voor rivieren, meren en estuaria in 2050 een balans tussen enerzijds ecologische draagkracht en waterbeheer (waterveiligheid, zoetwatervoorziening en waterkwaliteit) en anderzijds de opgaven voor hernieuwbare energie, voedsel, visserij en andere economische activiteiten." De bijbehorende Kennis- en innovatieopgave is: Hoe te komen tot visserij met minder emissie, betere arbeidsomstandigheden, diervriendelijker, met minder bodemberoering en selectiever, terwijl toch een goede boterham verdiend wordt.

De visserij draagt bij aan de voedselvoorziening. Visbestanden kunnen opnieuw groeien maar zijn niet onuitputtelijk. De manier waarop de visbestanden in de Noordzee bevist worden vereist dat dit zodanig gebeurt dat het vermogen van de visbestanden (commercieel en niet-commercieel) om zich voort te planten en het mariene milieu (de bodem, het bodemleven, andere soorten) gewaarborgd blijft. Met kennis en innovatie worden oplossingen gezocht om te komen tot een visserij met verdiencapaciteit maar zonder negatieve effecten op het ecosysteem en opvarenden, dat optimaal gebruik maakt van diversificatie in te vangen soorten en daarmee verspilling voorkomt.

\section{Wat beoogt het MMIP?}

\section{Doelstellingen MMIP}

Doelstellingen van dit MMIP is om ervoor te zorgen dat de zee- en kustvisserij op de Noordzee ecologisch, economisch en sociaal duurzaam is en een bron van gezond voedsel voor burgers van de EU vormt, waarbij ongewenste bijvangsten verminderd worden. Dit bevordert een dynamische visserijsector en een goede levensstandaard voor de visserijgemeenschappen. Daarnaast draagt dit MMIP bij aan de inpasbaarheid van de visserij in de energietransitie die nu plaatsvindt op de Noordzee. Het MMIP volgt uit de missie van LNV voor een Duurzame en veilige Noordzee (Missie E) en bestaat uit een aantal deelthema's zoals genoemd in de kennis- en innovatieopgave. Het MMIP omvat de ontwikkeling van kennis, concepten, ondersteunende technologie en maximale implementatie in de praktijk (van reeds bestaande technieken) voor de volgende deelthema's:

1. Versterken van het beheer van de visbestanden

2. Verminderen van emissies

3. Verbeteren van arbeidsomstandigheden

4. Verbeteren van dierenwelzijn

5. Verminderen van bodemberoering

6. Verbeteren van selectiviteit

7. Verbeteren van economisch perspectief

8. Systeemveranderingen 
9. Circulaire visserij (Zero Impact Visserij) onder te verdelen in 'zero impact kotter', alternatieve opties voor pulsvisserij en circulaire viskweek.

\section{Deelprogramma's en fasering}

Een duurzame visserij omvat zowel de duurzame exploitatie van de visbestanden als ook een socioeconomisch gezonde sector en vereist zowel nationaal als internationaal onderzoek. Waar een socioeconomische gezonde sector veelal nationaal onderzoek betreft, is onderzoek naar de duurzame exploitatie van de visbestanden onvermijdelijk een internationale aangelegenheid. In de Programmeringsstudie Visserij is een uitgebreider overzicht opgenomen.

Tabel 1. Overzicht van de belangrijkste (door)lopende projecten en programma's.

\begin{tabular}{|c|c|c|c|}
\hline $\begin{array}{l}\text { Onderzoeksfase TRL 1- } \\
3 \\
\text { (NwO, KNAW, EU, } \\
\text { Kennis-basis, } \\
\text { strategische middelen } \\
\text { etc.) }\end{array}$ & $\begin{array}{l}\text { Ontwikkelfase TRL 4-6 } \\
\text { (toegepast onderzoek, } \\
\text { beleidsondersteunend } \\
\text { onderzoek) }\end{array}$ & $\begin{array}{l}\text { Demonstratiefase TRL } \\
7-9 \\
\text { (MIT, POP, fieldlabs, } \\
\text { etc.) }\end{array}$ & $\begin{array}{l}\text { Implementatiefase } \\
\text { (subsidies, } \\
\text { investeringen, } \\
\text { regelgeving, } \\
\text { kennisverspreiding, } \\
\text { netwerken, campagnes } \\
\text { etc.) }\end{array}$ \\
\hline $\begin{array}{l}\text { Verduurzaming van de } \\
\text { zee- en kustvisserij op de } \\
\text { Noordzee }\end{array}$ & & & \\
\hline $\begin{array}{l}\text { * Kennisbasis Wettelijke } \\
\text { Onderzoekstaken WOT } \\
\text { (o.a. ICES; } \\
\text { bestandsopnamen). } \\
\text { * Beleidsondersteunend } \\
\text { Onderzoek (BO) } \\
\text { Natuurinclusieve visserij } \\
\text { * Beleidsondersteunend } \\
\text { Onderzoek (BO) } \\
\text { Ecologische basiskwaliteit } \\
\text { water } \\
\text { * EFMZV (o.a. OSW 2.0) }\end{array}$ & $\begin{array}{l}\text { * Beleidsondersteunend } \\
\text { Onderzoek (BO) } \\
\text { Natuurinclusieve visserij } \\
\text { (o.a. dierenwelzijn) } \\
\text { * Beleidsondersteunend } \\
\text { Onderzoek (BO) } \\
\text { Natuurinclusieve energie } \\
\text { * Kennisbasis (o.a. } \\
\text { camera- \& akoestische } \\
\text { detectie) } \\
\text { * EFMZV (o.a. OsW 2.0; } \\
\text { puls assessment) }\end{array}$ & $\begin{array}{l}\text { * EFMZV (o.a. innovatie } \\
\text { garnalenpuls; puls } \\
\text { assessment) }\end{array}$ & $\begin{array}{l}* \text { Website Pulse } \\
* \text { Kennisonline }\end{array}$ \\
\hline
\end{tabular}

Tabel 2. Kennis en innovatieopgaven

\begin{tabular}{|c|c|c|c|}
\hline $\begin{array}{l}\text { Onderzoeksfase TRL 1-3 } \\
\text { (NWO, KNAW, EU, Kennis- } \\
\text { basis, strategische middelen } \\
\text { etc.) }\end{array}$ & $\begin{array}{l}\text { Ontwikkelfase TRL 4- } \\
6 \text { (toegepast } \\
\text { onderzoek, } \\
\text { beleidsondersteunen } \\
\text { d onderzoek) }\end{array}$ & $\begin{array}{l}\text { Demonstratiefase T } \\
\text { RL 7-9 (MIT, POP, } \\
\text { fieldlabs, etc.) }\end{array}$ & $\begin{array}{l}\text { Implementatiefase } \\
\text { (subsidies, } \\
\text { investeringen, } \\
\text { regelgeving, } \\
\text { kennisverspreiding, } \\
\text { netwerken, } \\
\text { campagnes etc.) }\end{array}$ \\
\hline $\begin{array}{l}\text { Verduurzaming van de zee- en } \\
\text { kustvisserij op de Noordzee }\end{array}$ & & & \\
\hline $\begin{array}{l}\text { Deelthema: Versterken beheer } \\
\text { visbestanden }\end{array}$ & & & \\
\hline $\begin{array}{l}\text {-Verbeteren van de toegepaste } \\
\text { kennisbasis voor het beheer van } \\
\text { gegevensarme bestanden (veelal } \\
\text { commerciële bijvangstsoorten) }\end{array}$ & $\begin{array}{l}\text {-Ontwikkelen van } \\
\text { innovatieve } \\
\text { bemonsterings- en } \\
\text { monitoringsmethodes } \\
\text { voor gegevensarme }\end{array}$ & $\begin{array}{l}\text {-Uitvoeren van } \\
\text { proefprojecten in } \\
\text { nauwe samenwerking } \\
\text { tussen de } \\
\text { visserijsector en }\end{array}$ & $\begin{array}{l}\text {-Welke financiering en } \\
\text { aanpalende } \\
\text { maatregelen zijn nodig } \\
\text { om succesvolle nieuwe } \\
\text { visstand- }\end{array}$ \\
\hline
\end{tabular}




\begin{tabular}{|c|c|c|c|}
\hline $\begin{array}{l}\text { Onderzoeksfase TRL 1-3 } \\
\text { (NWO, KNAW, EU, Kennis- } \\
\text { basis, strategische middelen } \\
\text { etc.) }\end{array}$ & $\begin{array}{l}\text { Ontwikkelfase TRL 4- } \\
6 \text { (toegepast } \\
\text { onderzoek, } \\
\text { beleidsondersteunen } \\
\text { d onderzoek) }\end{array}$ & $\begin{array}{l}\text { Demonstratiefase T } \\
\text { RL 7-9 (MIT, POP, } \\
\text { fieldlabs, etc.) }\end{array}$ & $\begin{array}{l}\text { Implementatiefase } \\
\text { (subsidies, } \\
\text { investeringen, } \\
\text { regelgeving, } \\
\text { kennisverspreiding, } \\
\text { netwerken, } \\
\text { campagnes etc.) }\end{array}$ \\
\hline $\begin{array}{l}\text {-Ontwikkelen van fundamentele } \\
\text { kennis over de verspreiding van } \\
\text { visbestanden (en de gevolgen voor } \\
\text { maximaal duurzame oogst } \\
\text { mogelijkheden) als gevolg van } \\
\text { klimaatverandering } \\
\text { - Versterking van } \\
\text { (gedragseconomische) kennis over } \\
\text { visserijgedrag om zo de effecten } \\
\text { van "verplaatsingsgedrag" } \\
\text { (displacement) op bestanden, } \\
\text { ecosysteem en rentabiliteit als } \\
\text { geval van gebiedssluitingen } \\
\text { (natuur, windparken) beter vooraf } \\
\text { te kunnen voorspellen. } \\
\text { - Ontwikkelen van fundamentele } \\
\text { kennis in het toepassen van een } \\
\text { ecosysteem-benadering in het } \\
\text { bepalen van TACs en quota } \\
\text { - Fundamenteel onderzoek naar de } \\
\text { effecten van de aanlandplicht. }\end{array}$ & $\begin{array}{l}\text { bestanden (DNA- } \\
\text { technieken, } \\
\text { cameradetectie met } \\
\text { automatische } \\
\text { beeldherkenning)*. }\end{array}$ & $\begin{array}{l}\text { onderzoekers, waarbij } \\
\text { directe verbinding met } \\
\text { ICES essentieel is. } \\
\text { - Uitvoeren van } \\
\text { scenariomodellen } \\
\text { m.b.t. verandering in } \\
\text { visserijgedrag en de } \\
\text { effecten op bestanden, } \\
\text { ecosysteem en } \\
\text { rentabiliteit. }\end{array}$ & $\begin{array}{l}\text { onderzoektechnieken } \\
\text { standaard onderdeel te } \\
\text { maken van het } \\
\text { visserijonderzoek. }\end{array}$ \\
\hline
\end{tabular}

Deelthema: Verminderen emissies

\begin{tabular}{|c|c|c|c|}
\hline $\begin{array}{l}\text { - Fundamenteel en toegepast } \\
\text { onderzoek gericht op } \\
\text { scheepsinnovatie en duurzamere } \\
\text { voortstuwingssystemen gericht op } \\
\text { efficiëntieverbetering } \\
\text { - Fundamenteel en toegepast } \\
\text { onderzoek gericht op vloottransitie } \\
\text { dat bijdraagt aan vermindering } \\
\text { van emissies (brandstof en } \\
\text { geluid). }\end{array}$ & $\begin{array}{l}\text { - Ontwikkelen van } \\
\text { lichter vistuig } \\
\text { - Inzicht in de } \\
\text { benodigde } \\
\text { infrastructuur voor } \\
\text { nieuwe } \\
\text { voortstuwingssystemen } \\
\text { in de visserij*. } \\
\text { - Ontwikkelen van } \\
\text { software om visroutes } \\
\text { efficiënter in te } \\
\text { plannen. }\end{array}$ & $\begin{array}{l}\text { - Uitvoeren van pilots } \\
\text { van lichter vistuig om } \\
\text { inzicht te krijgen in } \\
\text { praktische } \\
\text { haalbaarheid en } \\
\text { rendabiliteit, waarbij } \\
\text { zorg wordt gedragen } \\
\text { voor nationaal én } \\
\text { internationaal } \\
\text { draagvlak } \\
\text { - Uitvoeren van } \\
\text { scenario-modellen in } \\
\text { vloottransities en de } \\
\text { effecten op emissie- } \\
\text { vermindering. } \\
\text { - Kan een efficiëntie- } \\
\text { criterium of een } \\
\text { emissie-quotum } \\
\text { bijdragen aan het } \\
\text { verminderen van } \\
\text { emissies. }\end{array}$ & $\begin{array}{l}\text { - Hoe kunnen } \\
\text { visserijondernemers } \\
\text { gestimuleerd worden } \\
\text { over te stappen naar } \\
\text { duurzamere } \\
\text { brandstoffen. }\end{array}$ \\
\hline \multicolumn{4}{|l|}{$\begin{array}{l}\text { Deelthema: Verbeteren } \\
\text { arbeidsomstandigheden }\end{array}$} \\
\hline
\end{tabular}




\begin{tabular}{|c|c|c|c|}
\hline $\begin{array}{l}\text { Onderzoeksfase TRL 1-3 } \\
\text { (NwO, KNAW, EU, Kennis- } \\
\text { basis, strategische middelen } \\
\text { etc.) }\end{array}$ & $\begin{array}{l}\text { Ontwikkelfase TRL 4- } \\
6 \text { (toegepast } \\
\text { onderzoek, } \\
\text { beleidsondersteunen } \\
\text { d onderzoek) }\end{array}$ & $\begin{array}{l}\text { Demonstratiefase T } \\
\text { RL 7-9 (MIT, POP, } \\
\text { fieldlabs, etc.) }\end{array}$ & $\begin{array}{l}\text { Implementatiefase } \\
\text { (subsidies, } \\
\text { investeringen, } \\
\text { regelgeving, } \\
\text { kennisverspreiding, } \\
\text { netwerken, } \\
\text { campagnes etc.) }\end{array}$ \\
\hline $\begin{array}{l}\text { Noordzee op de arbeidsmarkt van } \\
\text { de visserijsector } \\
\text { - Toegepaste kennisontwikkeling in } \\
\text { de benodigde toekomstige } \\
\text { vaardigheden van vissers om te } \\
\text { kunnen blijven vissen in de } \\
\text { toekomstige Noordzee } \\
\text { - Fundamenteel onderzoek in de } \\
\text { inzet van buitenlandse } \\
\text { werknemers in de sector } \\
\text { - Kan een alternatief } \\
\text { betalingssysteem bijdragen aan de } \\
\text { financiële zekerheid en veiligheid } \\
\text { van bemanningsleden. }\end{array}$ & $\begin{array}{l}\text { boord, o.a. om de kans } \\
\text { op letsel bij de } \\
\text { bemanning te } \\
\text { verminderen, } \\
\text { robotisering*. } \\
\text { - Ontwikkelen van } \\
\text { veiligheidsmateriaal } \\
\text { zodanig dat ze de } \\
\text { drager niet belemmeren } \\
\text { in het werk } \\
\text { - Scheepsinnovatie } \\
\text { t.b.v. optimale } \\
\text { arbeidsomstandigheden } \\
\text { *. } \\
\text { - Ontwikkelen van } \\
\text { werkeilanden en/of } \\
\text { moederschepen voor de } \\
\text { visserij t.b.v. } \\
\text { verwerking en/of } \\
\text { overnachting*. } \\
\text { - Ontwikkelen van } \\
\text { (radicale) innovatieve } \\
\text { vistechnieken en netten } \\
\text { gericht op het vangen } \\
\text { van doelsoorten } \\
\text { alleen*. }\end{array}$ & $\begin{array}{l}\text { aan boord te toetsen } \\
\text { op praktische } \\
\text { haalbaarheid en } \\
\text { rendabiliteit, waarbij } \\
\text { zorg wordt gedragen } \\
\text { voor nationaal én } \\
\text { internationaal } \\
\text { draagvlak } \\
\text { - Uitvoeren van } \\
\text { proefprojecten met } \\
\text { nieuw ontworpen } \\
\text { veiligheidsspullen } \\
\text { - Vergelijkend } \\
\text { onderzoek naar } \\
\text { verbeteringen in } \\
\text { arbeidsomstandighede } \\
\text { n in de visserij in } \\
\text { andere landen. }\end{array}$ & $\begin{array}{l}\text { het beste te behalen in } \\
\text { het visserij onderwijs of } \\
\text { is handhaving op } \\
\text { arbeidsomstandigheden } \\
\text { effectiever } \\
\text { - Kunnen internationale } \\
\text { afspraken gemaakt } \\
\text { worden vb. over } \\
\text { internationale erkenning } \\
\text { van diploma's en } \\
\text { veiligheidsafspraken aan } \\
\text { boord }\end{array}$ \\
\hline \multicolumn{4}{|l|}{$\begin{array}{l}\text { Deelthema: Verbeteren } \\
\text { dierenwelzijn }\end{array}$} \\
\hline $\begin{array}{l}\text { - Systeemanalyse van het vis- en } \\
\text { verwerkingsproces om inzicht te } \\
\text { krijgen in de mogelijkheden om } \\
\text { negatieve effecten op } \\
\text { dierenwelzijn gedurende het vis- } \\
\text { en verwerkingsproces te } \\
\text { mitigeren. } \\
\text { - Meer inzicht in welzijnsbehoeften } \\
\text { van vissen (soorten die het } \\
\text { betreft); dit geeft inzicht in de } \\
\text { daadwerkelijke belasting van de } \\
\text { dieren. }\end{array}$ & $\begin{array}{l}\text { - Ontwikkelen van } \\
\text { (radicale) innovatieve } \\
\text { vistechnieken en netten } \\
\text { gericht op het vangen } \\
\text { van doelsoorten } \\
\text { alleen*. } \\
\text { - Innoveren van het } \\
\text { vangstverwerkingsproc } \\
\text { es aan boord gericht op } \\
\text { overlevingskans van } \\
\text { bijvangst*. } \\
\text { - Ontwikkelen van } \\
\text { diervriendelijke } \\
\text { verdovingsmethodes } \\
\text { en/of dodingsmethodes } \\
\text { aan boord*. }\end{array}$ & $\begin{array}{l}\text { - Uitvoeren van pilots } \\
\text { van } \\
\text { vangstverwerkingspro } \\
\text { cessen die bijdragen } \\
\text { aan de } \\
\text { overlevingskans van } \\
\text { bijvangst, waarbij zorg } \\
\text { wordt gedragen voor } \\
\text { nationaal én } \\
\text { internationaal } \\
\text { draagvlak } \\
\text { - Uitvoeren van pilots } \\
\text { van } \\
\text { verdovingsmethodes } \\
\text { en/of } \\
\text { dodingsmethodes aan } \\
\text { boord, waarbij zorg } \\
\text { wordt gedragen voor } \\
\text { nationaal én } \\
\text { internationaal } \\
\text { draagvlak }\end{array}$ & $\begin{array}{l}\text { - Hoe kan } \\
\text { gedragsverandering bij } \\
\text { schippers en } \\
\text { bemanningsleden } \\
\text { behaald worden omtrent } \\
\text { dierenwelzijn } \\
\text { - Kunnen bestaande } \\
\text { duurzaamheidscertificat } \\
\text { en uitgebreid worden } \\
\text { met een dierenwelzijn } \\
\text { aspect } \\
\text { - Kan een nieuw } \\
\text { certificaat ontwikkeld } \\
\text { worden met oog op } \\
\text { dierenwelzijn. }\end{array}$ \\
\hline
\end{tabular}




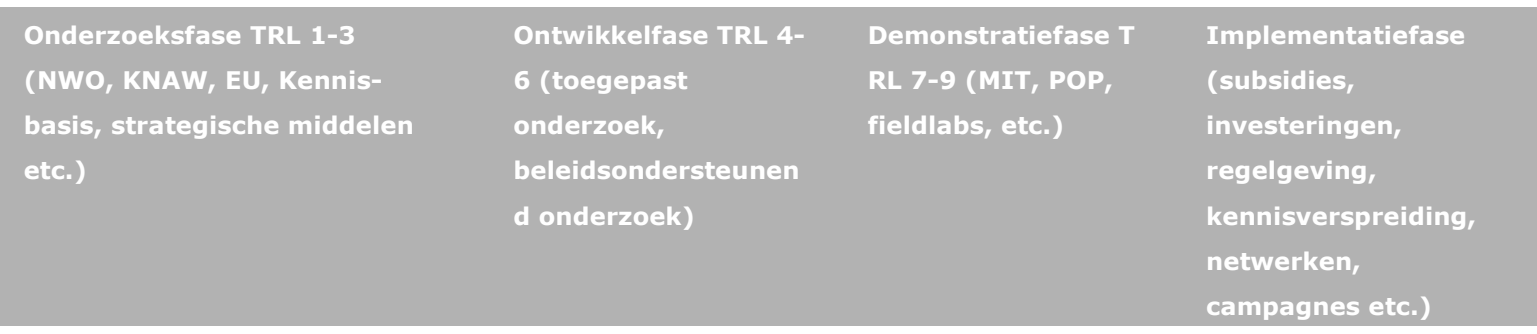

- Vergelijkend

onderzoek naar

verbeteringen in

dierenwelzijn in de

visserij in andere

landen.

Deelthema: Verminderen

bodemberoering

- Versterken fundamentele

\section{- Ontwikkelen van}

innovatieve

kennisontwikkeling van het

bodemecosysteem en identificatie

van de kwetsbare gebieden op de

Noordzee

- Versterken toegepast

kennisontwikkeling in input-

systemen (credits, quota) om

minder in kwetsbare gebieden te

vissen.

- In hoeverre zijn gebieden met een hoge bodemdynamiek interessant voor de visserij

(vangst, doelsoorten,

bereikbaarheid)

- Fundamenteel en toegepast onderzoek gericht op vloottransitie dat bijdraagt aan vermindering

van bodemberoering.

-Fundamenteel en toegepast

onderzoek naar vissen op basis

van 'efficiëntie', (niet alleen MSY)

zoals hoeveelheid

bodemberoering/kg vis, $\mathrm{CO} 2$ per

$\mathrm{kg} / \mathrm{vis}$, etc.

- Versterken kennis over

hersteltijden per bodemtype

(dynamisch/niet dynamisch) na

bevissing met bodemberoerende

vistuig

- Versterken fundamenteel inzicht

in het effect van bodemberoering

van verschillende ingrepen

(visserij, zandwinning etc.) op de

Noordzee

Deelthema: Verbeteren

selectiviteit

- Versterken fundamentele kennis van visgedrag in het algemeen

(visgedrag voor het vistuig, wanneer het schip aankomt, in het net)

\section{vistechnieken met}

minder

bodemberoering*.

- Vaststellen van

ecologische effecten

van nieuw ontwikkelde

vistechnieken*.

- Vaststellen van socioeconomische effecten

van nieuw ontwikkelde vistechnieken.

$\begin{array}{ll}\begin{array}{ll}\text { - Uitvoeren van pilots } \\ \text { van nieuwe }\end{array} & \begin{array}{l}\text { - Hoe kan ruimte } \\ \text { (financieel, regelgeving) } \\ \text { vistechnieken om }\end{array} \\ \begin{array}{l}\text { inzicht te krijgen in } \\ \text { praktische }\end{array} & \begin{array}{l}\text { visserijondernemers om } \\ \text { te kunnen innoveren }\end{array} \\ \text { haalbaarheid en } & \text { - Welke controle \& } \\ \text { rentabiliteit, waarbij } & \text { handhaving } \\ \text { zorg wordt gedragen } & \text { maatregelen kunnen } \\ \text { voor nationaal én } & \text { toegepast worden } \\ \text { internationaal } & \\ \text { draagvlak } & \\ \text { - Realiseren van } & \\ \text { Europees commitment } & \\ \text { \& draagvlak bij het } & \\ \text { toepassen van input- } & \\ \text { systemen om minder } & \\ \text { in kwetsbare gebieden } & \\ \text { te vissen i.v.m. } & \\ \text { jurisdictie. }\end{array}$




\begin{tabular}{|c|c|c|c|}
\hline $\begin{array}{l}\text { Onderzoeksfase TRL 1-3 } \\
\text { (NWO, KNAW, EU, Kennis- } \\
\text { basis, strategische middelen } \\
\text { etc.) }\end{array}$ & $\begin{array}{l}\text { Ontwikkelfase TRL 4- } \\
6 \text { (toegepast } \\
\text { onderzoek, } \\
\text { beleidsondersteunen } \\
\text { d onderzoek) }\end{array}$ & $\begin{array}{l}\text { Demonstratiefase T } \\
\text { RL 7-9 (MIT, POP, } \\
\text { fieldlabs, etc.) }\end{array}$ & $\begin{array}{l}\text { Implementatiefase } \\
\text { (subsidies, } \\
\text { investeringen, } \\
\text { regelgeving, } \\
\text { kennisverspreiding, } \\
\text { netwerken, } \\
\text { campagnes etc.) }\end{array}$ \\
\hline $\begin{array}{l}\text { - Inzicht in (mogelijk } \\
\text { veranderende) verspreiding van } \\
\text { commerciële en niet-commerciële } \\
\text { soorten als gevolg van } \\
\text { klimaatverandering. }\end{array}$ & $\begin{array}{l}\text { van doelsoorten } \\
\text { alleen*. } \\
\text { - Ontwikkelen van } \\
\text { precisie visserij } \\
\text { technieken (camera } \\
\text { detectie, sonar detectie, } \\
\text { etc.)*. } \\
\text { - Ontwikkelen hightech } \\
\text { oplossingen die real } \\
\text { time informatie over } \\
\text { visserij en vangsten } \\
\text { leveren en } \\
\text { voorspelbaarheid van } \\
\text { locatie van } \\
\text { visbestanden kan } \\
\text { verbeteren*. } \\
\text { - Vaststellen van } \\
\text { ecologische effecten } \\
\text { van nieuw ontwikkelde } \\
\text { vistechnieken } \\
\text { - Vaststellen van socio- } \\
\text { economische effecten } \\
\text { van nieuw ontwikkelde } \\
\text { vistechnieken } \\
\text { - Benutting en } \\
\text { versterking van het } \\
\text { Visserij } \\
\text { Innovatiecentrum en de } \\
\text { vamenwerking met } \\
\text { viscoöperaties en } \\
\text { vanciers }\end{array}$ & $\begin{array}{l}\text { haalbaarheid en } \\
\text { rentabiliteit, waarbij } \\
\text { zorg wordt gedragen } \\
\text { voor nationaal én } \\
\text { internationaal } \\
\text { draagvlak } \\
\text { - Uitbouw Visserij } \\
\text { Innovatie Centrum als } \\
\text { spil voor innovatie } \\
\text { pilots. }\end{array}$ & \\
\hline
\end{tabular}

Deelthema: Verbeteren

economisch perspectief

- Fundamenteel en toegepast onderzoek gericht op de inpasbaarheid en medegebruik van de visserij op de Noordzee (viscorridors tussen windparken), inzicht in de kansen voor visserij op de 'nieuwe' Noordzee (vlootgrootte, type schip, visserijactiviteiten, a.g.v. Brexit).

- Toegepast onderzoek naar medegebruik van verschillende typen visserij in windparken.

- Fundamenteel en toegepast onderzoek naar multi-use schepen (combineren van activiteiten zoals visserij, aquacultuur, onderhoud).
- Ontwikkelen van nieuwe vistechnieken voor in windparken

- Vaststellen van ecologische effecten van nieuw ontwikkelde vistechnieken

- Vaststellen van socioeconomische effecten van nieuw ontwikkelde vistechnieken.

- Het ontwikkelen van een vorm van Maatschappelijke Kosten Baten Analyse die is toegespitst op de
- Uitvoeren van pilots van alternatieve (precisie) vistechnieken in windparken om inzicht te krijgen in praktische haalbaarheid en rendabiliteit, waarbij zorg wordt gedragen voor nationaal én internationaal draagvlak

- Uitvoeren van pilots in het kader van medegebruik

\author{
- Hoe kunnen \\ visserijondernemers \\ gestimuleerd worden \\ om te innoveren en te \\ anticiperen op de \\ toekomst \\ - Hoe kan gezorgd \\ worden dat visserij in \\ windparken wordt \\ toegestaan \\ - Hoe kan de consument \\ meegenomen worden \\ om bereid te zijn een \\ hogere prijs te betalen \\ voor duurzamere vis \\ - Hoe kunnen \\ duurzaamheid en
}




\begin{tabular}{|c|c|c|c|}
\hline $\begin{array}{l}\text { Onderzoeksfase TRL 1-3 } \\
\text { (NWO, KNAW, EU, Kennis- } \\
\text { basis, strategische middelen } \\
\text { etc.) }\end{array}$ & $\begin{array}{l}\text { Ontwikkelfase TRL 4- } \\
6 \text { (toegepast } \\
\text { onderzoek, } \\
\text { beleidsondersteunen } \\
\text { d onderzoek) }\end{array}$ & $\begin{array}{l}\text { Demonstratiefase T } \\
\text { RL 7-9 (MIT, POP, } \\
\text { fieldlabs, etc.) }\end{array}$ & $\begin{array}{l}\text { Implementatiefase } \\
\text { (subsidies, } \\
\text { investeringen, } \\
\text { regelgeving, } \\
\text { kennisverspreiding, } \\
\text { netwerken, } \\
\text { campagnes etc.) }\end{array}$ \\
\hline $\begin{array}{l}\text { - Versterken inzicht in de socio- } \\
\text { economische gevolgen van de } \\
\text { ontwikkelingen op de Noordzee op } \\
\text { de visserij. } \\
\text { - Versterken toegepaste kennis in } \\
\text { alternatieve of nieuwe } \\
\text { verdienmodellen voor de visserij. } \\
\text { - Fundamenteel en toegepast } \\
\text { onderzoek naar andere vormen } \\
\text { van bedrijfsvoering. } \\
\text { - Toegepaste kennisontwikkeling in } \\
\text { de benodigde toekomstige } \\
\text { vaardigheden van vissers om te } \\
\text { kunnen blijven vissen in de } \\
\text { toekomstige Noordzee. } \\
\text {-Toegepast onderzoek naar het } \\
\text { inzetten van high tech oplossingen } \\
\text { t.b.v. kostenbesparing en } \\
\text { opbrengstverhoging in de visserij. } \\
\text { - Fundamenteel en toegepast } \\
\text { onderzoek naar benutting en } \\
\text { verwaarding van reststromen uit } \\
\text { de visserij. }\end{array}$ & $\begin{array}{l}\text { ketenbrede aspecten } \\
\text { van visserij. }\end{array}$ & $\begin{array}{l}\text { kleinschalige visserij } \\
\text { tussen windparken. } \\
\text { - Uitvoeren van pilots } \\
\text { omtrent gebruik van } \\
\text { reststromen uit de } \\
\text { visserij. }\end{array}$ & $\begin{array}{l}\text { ecologie, anticiperen op } \\
\text { de ontwikkelingen in de } \\
\text { sector goed ingebed } \\
\text { worden in het } \\
\text { visserijonderwijs } \\
\text { - Hoe omgaan met } \\
\text { afbreuk- risico's bij } \\
\text { visconsumenten, } \\
\text { financiers, beleggers in } \\
\text { visserij en de vis } \\
\text { afnemende sector. }\end{array}$ \\
\hline
\end{tabular}

Deelthema: Systeem-

veranderingen

Onderzoek naar een ander

systeem van visserij (nieuwe

Zie kennis- en

- Uitvoeren van pilots.

technieken, high tech

innovatievragen

toepassingen, robotisering, andere

hierboven gemarkeerd

organisatie vormen, andere

organisatie van de visserij zelf

- Fundamenteel en toegepast

onderzoek naar multi-use schepen

(combineren van activiteiten zoals

visserij, aquacultuur, onderhoud).

- Fundamenteel en toegepast

onderzoek naar zero impact

visserij/zero impact kotter.

- Fundamenteel en toegepast

onderzoek naar andere vormen

van bedrijfsvoering.

- Toegepast onderzoek naar het

inzetten van high tech oplossingen

t.b.v. kostenbesparing en

opbrengstverhoging in de visserij

Deelthema: Circulaire visserij

Zero impact kotter

- Pomptechnieken o.b.v.

- Installaties en

systemen bouwen en

elektrische aandrijving; zuig- en

injectie methoden activeren
- Testen op ware - - (Internationale)

grootte in beoogde

omstandigheden van vergunningen, wet- en

regelgeving, 


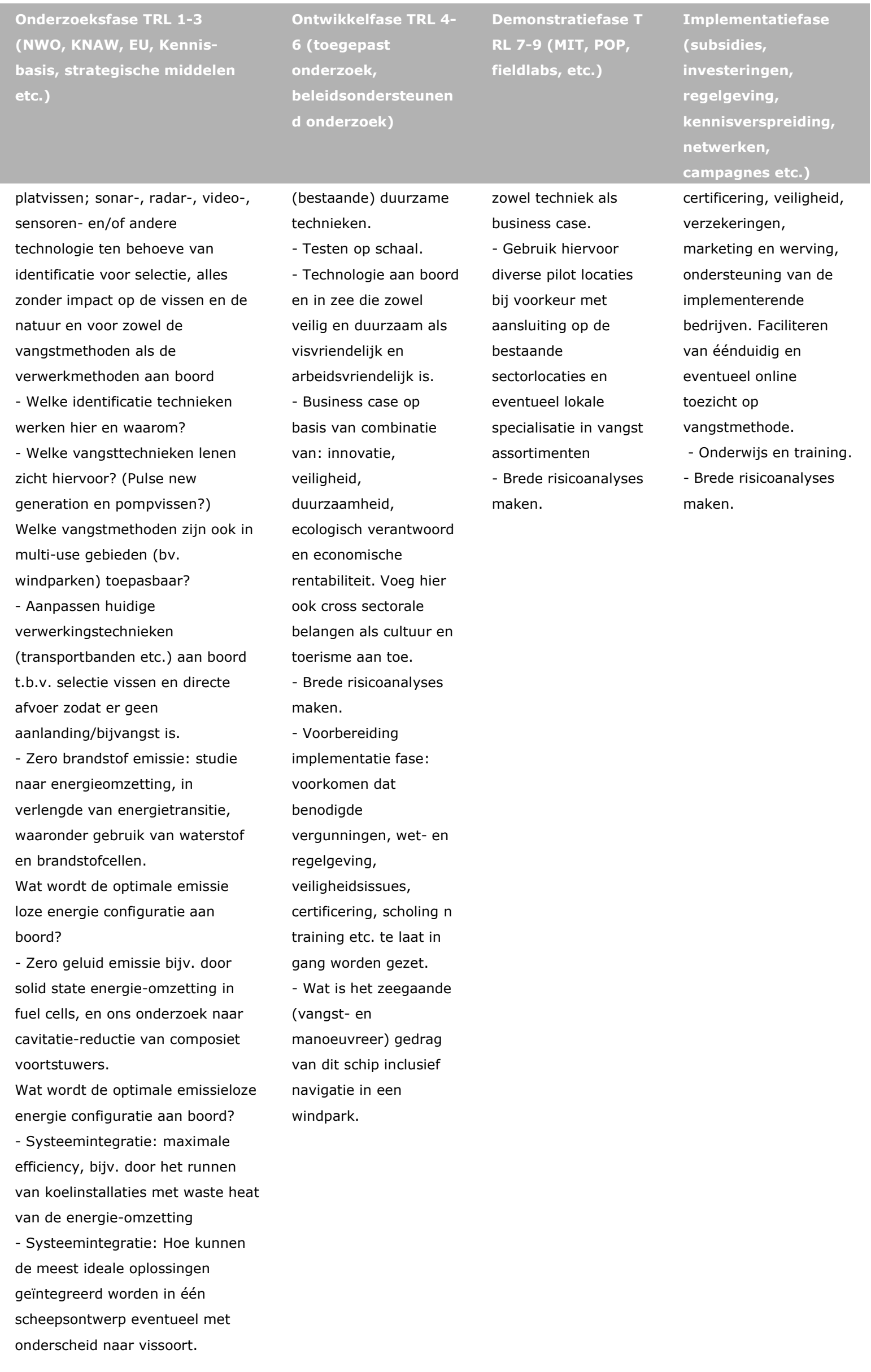

Alternatief vistuig/vangstmethode voor puls; voor tong en andere platvis 


\begin{tabular}{|c|c|c|c|}
\hline $\begin{array}{l}\text { Onderzoeksfase TRL 1-3 } \\
\text { (NWO, KNAW, EU, Kennis- } \\
\text { basis, strategische middelen } \\
\text { etc.) }\end{array}$ & $\begin{array}{l}\text { Ontwikkelfase TRL 4- } \\
6 \text { (toegepast } \\
\text { onderzoek, } \\
\text { beleidsondersteunen } \\
\text { d onderzoek) }\end{array}$ & $\begin{array}{l}\text { Demonstratiefase T } \\
\text { RL 7-9 (MIT, POP, } \\
\text { fieldlabs, etc.) }\end{array}$ & $\begin{array}{l}\text { Implementatiefase } \\
\text { (subsidies, } \\
\text { investeringen, } \\
\text { regelgeving, } \\
\text { kennisverspreiding, } \\
\text { netwerken, } \\
\text { campagnes etc.) }\end{array}$ \\
\hline $\begin{array}{l}\text { Haalbaarheidsstudie technisch en } \\
\text { financieel voor nieuwe } \\
\text { vangstmethode en nieuw vistuig. }\end{array}$ & $\begin{array}{l}\text { Technische ontwikkeling } \\
\text { nieuwe vangstmethode } \\
\text { en nieuw vistuig en op } \\
\text { ware grootte maken. }\end{array}$ & $\begin{array}{l}\text { Testen met aan één } \\
\text { kant kotter het nieuwe } \\
\text { vistuig en aan andere } \\
\text { kant kotter pulstuig } \\
\text { om zo goed mogelijke } \\
\text { vergelijking te kunnen } \\
\text { maken en resultaten } \\
\text { te kunnen vaststellen. }\end{array}$ & $\begin{array}{l}\text { Vergunning om met } \\
\text { nieuwe tuig te mogen } \\
\text { vissen. }\end{array}$ \\
\hline \multicolumn{4}{|l|}{$\begin{array}{l}\text { Circulaire viskweek: Eén vis op je } \\
\text { bord en één vis in de zee }\end{array}$} \\
\hline $\begin{array}{l}\text { - Wat zijn de fysiologische } \\
\text { randvoorwaarden voor het behoud } \\
\text { van een vitale } \\
\text { planktongemeenschap. } \\
\text { - Hoe ontwerp je een } \\
\text { kweeksysteem waarin plankton } \\
\text { zich onbelemmerd kan } \\
\text { ontwikkelen. } \\
\text { - Welke organismen hebben een } \\
\text { sleutelpositie in de plankton } \\
\text { voedselketen en welke organismen } \\
\text { zijn hiervan van essentieel belang } \\
\text { voor de ontwikkeling van } \\
\text { vislarven. } \\
\text { - Op welke manier kan de } \\
\text { ontwikkeling van een } \\
\text { planktongemeenschap worden } \\
\text { gevolg en bijgestuurd. }\end{array}$ & $\begin{array}{l}\text { - Kennis over } \\
\text { pelagische } \\
\text { planktongemeenschapp } \\
\text { en in relatie tot het } \\
\text { voorkomen van } \\
\text { vislarven optimaliseren } \\
\text { en bepalen welke } \\
\text { organismen een } \\
\text { cruciale rol spelen in de } \\
\text { voedselketen. } \\
\text { - Ontwikkelen van } \\
\text { plankton sparende } \\
\text { pompen en } \\
\text { filtersystemen. } \\
\text { - Ontwikkelen van } \\
\text { beeldherkennings- } \\
\text { apparatuur waarmee de } \\
\text { actuele ontwikkelingen } \\
\text { in een plankton } \\
\text { voedselweb gevolgd } \\
\text { kunnen worden. } \\
\text { - Bepalen van } \\
\text { ecologische en } \\
\text { economische waarden } \\
\text { van verschillende } \\
\text { vissoorten voor de } \\
\text { Noordzee. }\end{array}$ & $\begin{array}{l}\text { - Opzetten van een } \\
\text { kweek systeem met } \\
\text { de nieuwe } \\
\text { technologie. } \\
\text { - Overlevings- en } \\
\text { ontwikkelingstrials } \\
\text { voor verschillende } \\
\text { plankton organismen } \\
\text { (fyto- en zoöplankton) } \\
\text { in de systemen. } \\
\text { - Overlevings- en } \\
\text { ontwikkelingstrials } \\
\text { voor larven van } \\
\text { verschillende } \\
\text { vissoorten onder } \\
\text { verschillende } \\
\text { omstandigheden. }\end{array}$ & $\begin{array}{l}\text { - Opzet van een } \\
\text { functioneel broedhuis } \\
\text { met de nieuwe } \\
\text { technieken met } \\
\text { voldoende capaciteit om } \\
\text { de gewenste impact te } \\
\text { kunnen bereiken. } \\
\text { - Opzetten van } \\
\text { samenwerking met } \\
\text { visserijsector en } \\
\text { natuurorganisaties voor } \\
\text { de implementatie van } \\
\text { een herstelproject. }\end{array}$ \\
\hline
\end{tabular}

*ook van toepassing op de ontwikkelfase bij het onderdeel 'Systeemverandering'

\section{Positionering MMIP}

$\operatorname{Sector}(e n)$ :

Dit MMIP vormt tezamen met het MMIP 'Duurzame en veilige Noordzee' en MMIP Biogrondstoffen (deel Blauwe Ruimte) één geheel. Dit MMIP heeft interacties met Landbouw en Landgebruik, Agri \& Food, Water \& Maritiem, Logistiek, Life Sciences \& Health, en High Tech Systemen en Materialen, en Meet- en Detectietechnologie. Het onderwerp Visserij heeft raakvlakken met de MMIP Towards Zero Emissions van de Topsector Maritiem en de Blue Growth Strategie. 
De Nederlandse visserijsector is een gevarieerde sector, bestaande uit een grote (oceaan)zeevisserij ( 8 trawlers), de kottervisserij op platvis en andere bodemsoorten (290 schepen) en de kleine zeevisserij (225 schepen). In de nationale economie is de Nederlandse visserij van beperkte betekenis, echter voor de regionale economie draagt de aanvoer, de handel en de verwerking van vis in belangrijke mate bij aan de welvaart van de burgers. Eén van de sterktes is de samenwerking en kennisdeling tussen de kennisinstellingen, de visserijsector en overheden. In de onderzoekssamenwerking tussen Wageningen Marine Research en de Noordzee visserijsector is Nederland koploper in Europa. De Nederlandse visserijsector wordt in Europa gezien als een sterk innovatieve sector. De grote zeevisserij is goed georganiseerd en heeft een sterke financiële basis voor het uitvoeren van onderzoek en innovatie. De kottervisserij en kleine zee- en kustvisserij is georganiseerd via meerdere organisaties. Deze groep heeft geen eigen fondsen voor onderzoeksfinanciering en is grotendeels afhankelijk van subsidieprogramma's, zoals het Europees Fonds voor Maritieme Zaken en Visserij (EFMZV), voor innovatie en onderzoek. Waar de kotter- en garnalenvisserij via de landelijke organisaties gebruik maken van deze regelingen, mist de kleinschalige visserij de eigen middelen en organisatiegraad om hier effectief gebruik van te maken.

Samenhang met (bestaande) nationale en internationale agenda's

1. Europese Kaderrichtlijn Mariene Strategie (KRM);

2. Europese vogel- en Habitatrichtlijnen (Natura2000);

3. Europees Gemeenschappelijk Visserij Beleid (GVB);

4. Beleidsbrief Dierenwelzijn;

5. Strategische Agenda Noordzee 2030 en het daaraan gekoppelde traject rond het Noordzee Akkoord door het Overlegorgaan Fysieke Leefomgeving (OFL);

6. Europese Blue Growth Strategie 2020;

\section{Strategie internationaal}

Nederland heeft nog geen strategie voor de visserijsector. Op dit moment lopen meerdere trajecten die bezig zijn met het uitkristalliseren van de toekomst voor de Nederlandse visserij. Vanuit het OFL (Overlegorgaan Fysieke Leefomgeving) wordt gewerkt aan het Noordzee Akkoord, waarbij het vooral gaat om ruimtelijke afspraken over energie, voedsel en natuur op de Noordzee. Dit Noordzee Akkoord moet in de zomer 2019 gereed zijn. In samenhang met het OFL-traject wil het Ministerie van Landbouw, Natuur en Voedselkwaliteit samen met de visserijsector een visie ontwikkelen over de toekomst van de Noordzeevisserij waarbij ook rekening gehouden wordt met andere (niet ruimtelijke) ontwikkelingen.

\section{Innovatiesysteem en consortiumvorming}

De Nederlandse kottervisserij en de kleine zeevisserij bestaan veelal uit kleinere familiebedrijven. De grote pelagische visserij bestaat uit vier rederijen. Belangenvertegenwoordiging van de Noordzeevissers op nationaal niveau vindt plaats via vier visserijorganisaties, nl. VisNed (kottervisserij), de Nederlandse Vissersbond (zee-, kust- en binnenvisserij), de Coöperatieve Visserijorganisaties (een samenwerkingsverband van de vijf producentenorganisaties (PO's) van VisNed, de PO Nederlandse Vissersbonden en de PO De Roussant), en Netviswerk (kleinschalige kust- en binnenvissers). De leden kunnen onderling soms tegengestelde belangen hebben, hetgeen consortiumvorming bemoeilijkt. Innovaties in de Noordzeevisserij vinden plaats doordat individuele vissers, soms in samenwerking met een kennisinstelling, zelf netaanpassingen uitvoeren. $\mathrm{Er}$ is niet of nauwelijks sprake van consortiumvorming. Meestal is één van de landelijke organisaties hoofdaanvrager van een EFMZVproject. Sinds 2015 bestaat het Visserij Innovatiecentrum als testcentrum ter ondersteuning van de visserijsector bij technische ontwikkelingen aan vistuigen en netwerken. Voor de 'Circulaire Visserij' onderwerpen wordt samengewerkt door Visned, TUDelft, Bluelinked, Quotter, Port4Innovation1/Stichting Blauwe Polder, Bureau de Heer, Marin en TKI Maritiem; nieuwe partners zijn van harte welkom. 


\title{
Bijlage 14 MMIP Zeewierproductie in de Noordzee
}

\author{
MMIP Zeewierproductie in de Noordzee - versie 1 juni 2019 \\ Missie B - Klimaatneutrale landbouw en voedselproductie
}

\section{Maatschappelijke opgaven en missie doelstellingen}

Zeewier speelt een belangrijke rol in de mondiale koolstofcyclus. Zo'n $6 \%$ van de netto primaire productie wordt geproduceerd door zeewier. In West-Europa is er steeds meer belangstelling voor productie van zeewier als bron voor voedsel, diervoeder en bio-grondstof. Er is geen landbouwgrond nodig en veel soorten groeien in zout of brak water. Kostbare voedingsstoffen zoals fosfaten die via de rivieren in zee geloosd worden, kunnen via zeewier weer opgevangen worden. In Aziatische landen wordt zeewier al op grote schaal geoogst maar niet op basis van een duurzame productiewijze. De technologie die hiervoor nodig is, toegespitst op de situatie in de Noordzee, moet nog grotendeels ontwikkeld worden. De komende decennia zal op een groot deel van het Noordzee-oppervlak windmolenparken geplaatst worden. Medegebruik van windenergie met aangepaste vormen van visserij en productie van zeewier is één van de doelstellingen van de KIA Landbouw Water Voedsel. In de Programmeringsstudie Duurzame Noordzee worden de kennis- en innovatieopgaven voor het realiseren van medegebruik van windparken uitgewerkt (Steins et al., 2019). De Programmeringsstudie Visserij gaat in op het verwerken van reststromen uit de zee- en kustvisserij voor o.a. biogrondstoffen (Smith et al., 2019). Deze programmeringsstudies vormen een geheel met de voorliggende programmeringsstudie.

Doelstelling van dit deelthema (overigens ook een apart MMIP) is bij te dragen aan een grootschalige, rendabele en duurzame zeewierproductie op de Noordzee vanaf 2030 in combinatie met schelpdierproductie en natuurontwikkeling. In het MMIP Duurzame en veilige Noordzee wordt een systeembenadering geschetst voor een duurzaam medegebruik binnen de ecologische en ruimtelijke kaders van het systeem. Het deelprogramma (tevens MMIP) Zeewierproductie in de Noordzee is een voorbeeld van dit duurzaam medegebruik.

\section{Indeling in deelprogramma's}

Het deelprogramma (tevens MMIP) Zeewierproductie in de Noordzee bestaat uit een innovatietraject met 8 deelthema's. Elk deelthema heeft een eigen innovatieopgave. De verbinding tussen de deelthema's is essentieel; resultaten behaald binnen het ene deel zijn bepalend voor keuzes in een ander deelthema.

Het deelprogramma/MMIP omvat de ontwikkeling van kennis, concepten, ondersteunende technologie en maximale implementatie in de praktijk voor:

- De technische haalbaarheid en ontwikkeling van offshore hardware;

- De ruimtelijke inpassing in de Noordzee al dan niet in combinatie met windmolenparken;

- De ecologische haalbaarheid en mogelijke ecosysteemdiensten;

- De fysiologie en veredeling van Noordzeesoorten;

- De ontwikkeling van duurzame productiewijzen o.a. gericht op beheersing van ziekten en plagen en het circulair maken van zeewierproductie;

- De verwerking van geoogste biomassa, opslag- en transport technieken en de ontwikkeling van fractioneringstechnieken gericht op het winnen van economisch interessante componenten;

- De ontwikkeling van afzetmarkten, consumentenacceptatie en integrale business cases;

- Wet- en regelgeving op het gebied van zeewierproductie, en verwerking en toepassingen van geoogste biomassa. 


\section{Lopend en afgerond onderzoek}

Een overzicht van lopend en recent afgerond onderzoek wordt in onderstaande tabel gepresenteerd volgens de 8 deelthema's.

Tabel 1. Lopend onderzoek (niet uitputtend)

\begin{tabular}{|c|c|c|c|c|}
\hline Deelprogramma & $\begin{array}{l}\text { Onderzoeksfase TRL 1- } \\
3 \\
\text { (NWO, KNAW, EU, } \\
\text { Kennis-basis, } \\
\text { strategische middelen } \\
\text { etc.) }\end{array}$ & $\begin{array}{l}\text { Ontwikkelfase TRL } \\
4-6 \\
\text { (toegepast } \\
\text { onderzoek, } \\
\text { beleidsondersteun } \\
\text { end onderzoek) }\end{array}$ & $\begin{array}{l}\text { Demonstratiefase } \\
\text { TRL 7-9 } \\
\text { (MIT, POP, } \\
\text { fieldlabs, etc.) }\end{array}$ & $\begin{array}{l}\text { Implementatiefase } \\
\text { (subsidies, } \\
\text { investeringen, } \\
\text { regelgeving, } \\
\text { kennisverspreiding, } \\
\text { netwerken, } \\
\text { campagnes etc.) }\end{array}$ \\
\hline $\begin{array}{l}\text { 1. Technische } \\
\text { haalbaarheid: } \\
\text { ontwikkeling van } \\
\text { offshore } \\
\text { hardware }\end{array}$ & $\begin{array}{l}\text { Blue Growth (lopend } \\
\text { Marin) } \\
\text { H2020 Genialg (lopend } \\
\text { o.a. WR) }\end{array}$ & $\begin{array}{l}\text { Blue Growth Marin } \\
\text { (lopend Marin) } \\
\text { H2020 Genialg } \\
\text { (lopend o.a. WR) }\end{array}$ & & \\
\hline $\begin{array}{l}\text { 2. Ruimtelijke } \\
\text { inpassing op de } \\
\text { Noordzee }\end{array}$ & $\begin{array}{l}\text { BE-programma } \\
\text { Seaconomy (afgesloten) }\end{array}$ & $\begin{array}{l}\text { BE-programma } \\
\text { Seaconomy } \\
\text { (afgesloten) }\end{array}$ & & \\
\hline $\begin{array}{l}\text { 3. Ecologische } \\
\text { haalbaarheid }\end{array}$ & $\begin{array}{l}\text { WR-Projecten binnen } \\
\text { Beleidsondersteunend } \\
\text { Onderzoek en Kennisbasis } \\
\text { AF-16202 Proseaweed } \\
\text { (lopend WR) }\end{array}$ & $\begin{array}{l}\text { WR-Projecten binnen } \\
\text { Beleidsondersteunen } \\
\text { d Onderzoek en } \\
\text { Kennisbasis } \\
\text { AF-16202 } \\
\text { Proseaweed (lopend } \\
\text { WR) }\end{array}$ & & \\
\hline $\begin{array}{l}\text { 4. Ontwikkeling van } \\
\text { duurzame en } \\
\text { grootschalige } \\
\text { productiewijzen }\end{array}$ & $\begin{array}{l}\text { H2020 Genialg (lopend } \\
\text { o.a. WR) } \\
\text { H2020 Impaqt (lopend } \\
\text { o.a. Deltares) } \\
\text { H2020 Macrofuels (lopend } \\
\text { o.a. WR en TNO-ECN) } \\
\text { KB-30-003-016 - } \\
\text { Integrated Pest } \\
\text { Management in Aquatic } \\
\text { Farming Systems }\end{array}$ & $\begin{array}{l}\text { H2020 Genialg } \\
\text { (lopend o.a. WR) } \\
\text { H2020 Impaqt } \\
\text { (lopend o.a. } \\
\text { Deltares) } \\
\text { H2020 Macrofuels } \\
\text { (lopend o.a. WR en } \\
\text { TNO-ECN) } \\
\text { 1-2C-4 Marine lower } \\
\text { trophic food systems }\end{array}$ & $\begin{array}{l}\text { H2020 Genialg } \\
\text { (lopend o.a. WR) } \\
\text { H2020 Impaqt } \\
\text { (lopend o.a. } \\
\text { Deltares) } \\
\text { H2020 Macrofuels } \\
\text { (lopend o.a. WR en } \\
\text { TNO-ECN) } \\
\text { AgeaDemo (lopend, } \\
\text { o.a. TNO-ECN) } \\
\text { BE-project } \\
\text { Value@sea (lopend) }\end{array}$ & \\
\hline $\begin{array}{l}\text { 5. Fysiologie en } \\
\text { genetica van } \\
\text { Noordzeesoorten }\end{array}$ & $\begin{array}{l}\text { H2020 Genialg (lopend } \\
\text { o.a. WR) } \\
\text { AF-16202 Proseaweed } \\
\text { (lopend WR) }\end{array}$ & $\begin{array}{l}\text { H2020 Genialg } \\
\text { (lopend o.a. WR) } \\
\text { AF-16202 } \\
\text { Proseaweed (lopend } \\
\text { WR) }\end{array}$ & $\begin{array}{l}\text { H2020 Genialg } \\
\text { (lopend o.a. WR) }\end{array}$ & \\
\hline $\begin{array}{l}\text { 6. Verwerking van } \\
\text { geoogste } \\
\text { biomassa en } \\
\text { ontwikkeling van } \\
\text { fractioneringstech } \\
\text { nieken }\end{array}$ & $\begin{array}{l}\text { BE-programma } \\
\text { Seaconomy (afgesloten) } \\
\text { H2020-Macrocascade en } \\
\text { H2020 Macrofuels (lopend } \\
\text { o.a. WR en TNO-ECN) }\end{array}$ & $\begin{array}{l}\text { BE-programma } \\
\text { Seaconomy } \\
\text { (afgesloten) } \\
\text { H2020- } \\
\text { Macrocascade en } \\
\text { H2020 Macrofuels } \\
\text { (lopend o.a. WR en } \\
\text { TNO-ECN) }\end{array}$ & $\begin{array}{l}\text { BE-programma } \\
\text { Seaconomy } \\
\text { (afgesloten) } \\
\text { H2020-Macrocascade } \\
\text { en H2020 Macrofuels } \\
\text { (lopend o.a. WR en } \\
\text { TNO-ECN) }\end{array}$ & \\
\hline $\begin{array}{l}\text { 7. Economische } \\
\text { haalbaarheid: } \\
\text { ontwikkeling van }\end{array}$ & $\begin{array}{l}\text { BE-programma } \\
\text { Seaconomy (afgesloten) } \\
\text { H2020 Genialg (lopend } \\
\text { o.a. WR) }\end{array}$ & $\begin{array}{l}\text { BE-programma } \\
\text { Seaconomy } \\
\text { (afgesloten) } \\
\text { H2020 Genialg }\end{array}$ & & \\
\hline
\end{tabular}




\begin{tabular}{|c|c|c|c|c|}
\hline Deelprogramma & $\begin{array}{l}\text { Onderzoeksfase TRL 1- } \\
3 \\
\text { (NWO, KNAW, EU, } \\
\text { Kennis-basis, } \\
\text { strategische middelen } \\
\text { etc.) }\end{array}$ & $\begin{array}{l}\text { Ontwikkelfase TRL } \\
4-6 \\
\text { (toegepast } \\
\text { onderzoek, } \\
\text { beleidsondersteun } \\
\text { end onderzoek) }\end{array}$ & $\begin{array}{l}\text { Demonstratiefase } \\
\text { TRL 7-9 } \\
\text { (MIT, POP, } \\
\text { fieldlabs, etc.) }\end{array}$ & $\begin{array}{l}\text { Implementatiefase } \\
\text { (subsidies, } \\
\text { investeringen, } \\
\text { regelgeving, } \\
\text { kennisverspreiding, } \\
\text { netwerken, } \\
\text { campagnes etc.) }\end{array}$ \\
\hline $\begin{array}{l}\text { afzet en business } \\
\text { cases }\end{array}$ & $\begin{array}{l}\text { Interreg Bio4Save } \\
\text { (lopend) } \\
\text { AF-16202 Proseaweed } \\
\text { (lopend WR) } \\
\text { Interreg-Valgorize (lopend } \\
\text { o.a. NIOZ) } \\
\text { Zeevivo (lopend o.a. } \\
\text { NIOZ, WUR en VHL) }\end{array}$ & $\begin{array}{l}\text { (lopend o.a. WR) } \\
\text { Interreg Bio4Save } \\
\text { (lopend } \\
\text { AF-16202 } \\
\text { Proseaweed (lopend } \\
\text { WR) } \\
\text { Interreg-Valgorize } \\
\text { (lopend o.a. NIOZ) } \\
\text { Zeevivo (lopend o.a. } \\
\text { NIOZ, WUR en VHL) }\end{array}$ & & \\
\hline $\begin{array}{l}\text { 8. } \begin{array}{l}\text { Bestuurlijke } \\
\text { aspecten, wet- \& } \\
\text { regelgeving }\end{array}\end{array}$ & $\begin{array}{l}\text { BE-programma } \\
\text { Seaconomy (afgesloten) } \\
\text { SOMOS (afgesloten, o.a. } \\
\text { TNO, WUR) }\end{array}$ & $\begin{array}{l}\text { BE-programma } \\
\text { Seaconomy } \\
\text { (afgesloten) } \\
\text { SOMOS (afgesloten, } \\
\text { o.a. TNO, WUR) }\end{array}$ & & \\
\hline
\end{tabular}

Hieronder volgt een korte beschrijving van de lopende onderzoekprogramma's:

- Blue Growth programma Marin: maritieme vraagstukken rond (drijvende) windturbines, vis- en zeewierkweek, drijvende zonnepanelen en alle daarbij horende installatie-, oogst- en onderhoudssystemen.

- H2020 Genialg (2017-2020): GENetic diversity exploitation for Innovative macro-ALGal biorefinery. Onderzoekthema's: 1) Ethics requirements; 2) Selection, breeding, germplasm and biobanking; 3) Demonstration of large-scale seaweed farming; 4) Seaweed biorefinery prototype design and implementation; 5) Market validation and life-cycle analysis; 6) Socio-environmental benefits of seaweed farming; 7) Dissemination, Stakeholder Engagement, Knowledge Transfer, Outreach Capacity Building

- Het Belgische SEACONOMY (2016-2018) project is een multidisciplinair consortium van bedrijven, sectororganisaties en overheidsinstanties gericht op de ontwikkeling van een Vlaamse zeewier economie. Onderzoekthema's zijn:

- de economische haalbaarheid van de lokale kweek voor de niche markt;

- de duurzaamheid van de waardeketen;

- aankaarten belangrijkste externe barrières.

- AF-16202 Proseaweed (MIP-Zeewier) (2017-2021). Maatschappelijk InnovatieProgramma binnen TS-A\&F. Richt zich op kweek- een teeltaspecten (inclusief ecologie) en toepassingsmogelijkheden op het gebied van voeding en diervoeding

- H2020 Impaqt (2018-2021): Intelligent Management System for integrated multi-trophic Aquaculture: an advanced IMTA model is developed, which yields spatially explicit information on how the different farm components interact with the environment on the scale of an ecosystem and that can be used for planning decisions by both farmers and regulators.

- H2020 Macrofuels (2016-2019): aims to produce advanced biofuels from seaweed or macro-algae. Research themes: Increasing biomass supply; Improving the pre-treatment and storage of seaweed; Increasing bio-ethanol and bio-butanol production to economically viable concentrations by developing novel fermenting organisms; Increasing biogas yield to convert $90 \%$ of the available carbon in residues by adapting the organisms to seaweed; Developing thermochemical conversion of sugars to fuels from the $\mathrm{mg}$. scale to the $\mathrm{kg}$. scale; Performing an integral technoeconomic, sustainability and risk assessment of the entire seaweed to biofuel chain

- H2020 Macrocascade (2017-2020): objective is to prove the concept of the cascading marine macroalgal biorefinery. Research themes: Obtain optimized strains of seaweeds; Improve scalable cultivation of seaweeds; Improve methods for seaweed biomass preparation and storage stability; Develop patentable feed and food products with health promoting functionalities; Develop scalable 
and sustainable extraction/separation methods; Develop a variety of efficient and robust carbohydrate active enzymes, with a range of specificities of relevance for processing macroalgal polysaccharides; Study the economic viability of the macroalgae cascading valorization schemes; Quantitatively assess the sustainability of the seaweed-based value chains; Develop sustainable business cases for a "Blue Print" of the cascading marine macroalgal biorefinery

- EU-EASME project AlgaeDemo (2019-2021): demonstration of large scale seaweed cultivation at open sea and effects thereof on the ocean

- Value@sea (2017-2019): demonstratieproject in de Westdiep van een geïntegreerde zeeboerderij (7ha) voor de gecombineerde kweek van oesters, sint-jakobsschelpen en zeewier

- Bio4Save (2017-2019): de focus van het project ligt op biostimulanten op basis van zeewier. Daarnaast wordt gekeken naar de economische mogelijkheden van zeewier.

- ValgOrize (2019-2021): project gericht op de valorisatie van zeewier en microalgen als voedsel voor de Europese markt

- Zeevivo (2015-2019): The aim of the research project is to find out whether protein from seaweed can be used in fish food.

- $\quad$ SOMOS (2016-2018): Safe production of Marine Plants and use of Ocean Space. Het doel is het ontwikkelen en uitvoeren van een veiligheidsbeoordeling voor toepassingen van zeeplanten. Het veiligheidsraamwerk dat hier ontwikkeld is richt zich op gevaren in relatie tot arbeidsomstandigheden, gebruik als voedsel en veevoeder en milieu. Ook controle maatregelen om veilig multi-gebruik te bewerkstelligen zijn op een rijtje gezet.

Het lopend onderzoek bevindt zich dus vooral in de onderzoeks- en ontwikkelingsfase (tot TRL 7) en enkele activiteiten zitten ook in de demonstratiefase zoals uit Tabel 3.1 blijkt.

\section{Kennis en innovatie opgaven/witte vlekken}

Er vindt veel zeewieronderzoek plaats in Europa (zie tabel 3.1) maar het lopende onderzoek kenmerkt zich ook door een behoorlijke versnippering. Bovendien is er behoefte om nu echt de stap naar een grootschalige aanpak te maken. De kracht van het beoogde nationale innovatieprogramma Zeewierproductie in de Noordzee is een samenwerking van kennisinstellingen (w.o. alle TO2instellingen) en ondernemers binnen één of meerdere grootschalig demo-velden op de Noordzee, van waaruit deelvraagstukken kunnen worden opgepakt. Hierdoor ontstaat samenhang tussen alle deelprojecten. Een recent uitgevoerde stakeholder analyse geeft de volgende innovatieprioriteiten aan (dit betreft meer dan alleen onderzoek):

- Grootschalige pilots/demovelden (van tientallen hectares) op de Noordzee waar pionierende zeewierondernemers, natuurorganisaties en onderzoekers gezamenlijk implementatievraagstukken onderzoeken en oplossen. Capaciteit in havens waar gewerkt wordt aan logistieke vraagstukken en verwerking van het geoogste materiaal maakt hier deel van uit.

- In deze demovelden is ruimte voor gecombineerde productie van zeewier en schelpdieren. Bij schelpdieren gaat het enerzijds om de ontwikkeling van natuur en ecosysteemdiensten (aanleg platte oesterbanken), anderzijds om de ontwikkeling van commerciële productie (mosselkweek).

- In zeewier is risico op ophopen van verontreinigingen uit het water groot. Het is daarom van groot belang om rekeningen te houden met de kwaliteit van het water, voor de voedselveiligheid van zeewier.

- Pionierende zeewierondernemers hebben leningen nodig voor (voor)investeringen. Banken verlangen daarbij lange termijn contracten met afnemers. Marktontwikkeling is daarom een belangrijk onderdeel van het innovatieprogramma.

- $\quad$ Stimuleringsinstrumenten, vergelijkbaar met de eerste subsidies voor windmolens en zonnepanelen (onrendabele top), zijn nodig voor het overbruggen van de risicovolle implementatiefase van de productievelden.

- $\quad$ r is nieuwe en aanpassing van bestaande wetgeving nodig t.a.v. het verlenen van vergunningen, medegebruik binnen windparken, technische eisen, bescherming van het ecosysteem, certificering, voorwaarden voor milieu- en voedselkwaliteit etc.

- Kennisdeling, communicatie en opleiding is nodig als basis voor de ontwikkeling van een sterke sector en voor draagvlak binnen de maatschappij.

- Onderzoeksprioriteiten liggen bij de volgende onderwerpen:

- Ontwikkeling van grootschalige installaties die bestand zijn tegen de condities op de Noordzee en kostenefficiënt kunnen worden neergelegd, ontwikkeling van gemechaniseerde oogst en ent- 
methodes (door o.a. Marin, TNO, NIOZ, technische universiteiten i.s.m. Nederlandse offshore industrie).

- $\quad$ Ontwikkeling van efficiënte monitoringstechnieken op het gebied van ecologische interacties en nutriëntenbeschikbaarheid om ecologische effecten van grootschalige zeewierproductie op de Noordzee in kaart te brengen en te bewaken (door o.a. NIOZ, Deltares, WR, TNO, universiteiten i.s.m. zeewierondernemers)

- Ontwikkeling van (nieuwe) afzetkanalen en verwerkingstechnologieën van geoogste biomassa (door o.a. WR, TNO, universiteiten i.s.m. onder andere chemische, voedings-, diervoeder-, gewasbeschermingsindustrie)

- Fysiologie en genetica van Noordzeesoorten t.b.v. veredeling en karakterisering uitgangsmateriaal (door o.a. WR, NIOZ, universiteiten i.s.m. zeewierondernemers)

De onderzoeksprioriteiten bevatten zowel fundamentele als toegepaste vraagstukken. Zie ook tabel 3.2. De vraagstukken in de kolom "onderzoeksfase" betreffen het meer fundamentele onderzoek. Voor de hand ligt om hiervoor middelen van NWO en/of kennisbasis van de TO2-instituten in te zetten. Vraagstukken in de kolommen "ontwikkelfase" en "demonstratiefase" kunnen o.a. gefinancierd worden middels publiek-private samenwerking gefaciliteerd door o.a. TKI-Maritiem, TKI-Agri \& Food en TKIWind op Zee.

Cruciaal voor het tot stand brengen van een nationaal zeewierprogramma waarin o.a. alle TO2instellingen samenwerken, is een gezamenlijke aansturing vanuit de betrokken departementen: LNV, I\&W, EZK en OCW. Belangrijk bij het ontwikkelen van een gezamenlijke, departement overstijgende onderzoekagenda, waarin de diverse financieringsinstrumenten in samenhang worden ingezet en waarbij ook rekening wordt gehouden met uitkomsten uit lopende onderzoekprogramma's (zie tabel 3.1.) is een goede voorbereidingsfase. Bestaande instituties - bijvoorbeeld de CoP Blue Innovation Noordzee 2030, Stichting Noordzeeboerderij - kunnen hierbij ingezet worden.

Tabel 2. Witte vlekken in onderzoek voor nationaal programma Zeewierproductie in de Noordzee

\begin{tabular}{|c|c|c|c|c|}
\hline Deelprogramma & $\begin{array}{l}\text { Onderzoeksfase } \\
\text { TRL 1-3 } \\
\text { (NWO, KNAW, EU, } \\
\text { Kennis-basis, } \\
\text { strategische } \\
\text { middelen etc.) }\end{array}$ & $\begin{array}{l}\text { Ontwikkelfase TRL } \\
4-6 \\
\text { (toegepast } \\
\text { onderzoek, } \\
\text { beleidsondersteune } \\
\text { nd onderzoek) }\end{array}$ & $\begin{array}{l}\text { Demonstratiefase } \\
\text { TRL 7-9 } \\
\text { (MIT, POP, } \\
\text { fieldlabs, etc.) }\end{array}$ & $\begin{array}{l}\text { Implementatiefase } \\
\text { (subsidies, } \\
\text { investeringen, } \\
\text { regelgeving, } \\
\text { kennisverspreiding, } \\
\text { netwerken, } \\
\text { campagnes etc.) }\end{array}$ \\
\hline \multicolumn{5}{|c|}{ 1. Technische haalbaarheid: ontwikkeling van offshore hardware } \\
\hline $\begin{array}{l}\text { Eenvoudige, } \\
\text { grootschalige, } \\
\text { robuuste } \\
\text { productiesystemen } \\
\text { bestand tegen } \\
\text { golfslag en } \\
\text { stormcondities op de } \\
\text { Noordzee } \\
\text { Verankeringsconstruc } \\
\text { tie die veilig kan } \\
\text { worden toegepast } \\
\text { binnen } \\
\text { windmolenparken } \\
\text { Inzicht in } \\
\text { trekkrachten van } \\
\text { verschillende soorten } \\
\text { zeewier op de } \\
\text { constructie } \\
\text { Zeewiersystemen die } \\
\text { qua omvang en }\end{array}$ & $\begin{array}{l}\text { Ontwerp en } \\
\text { ontwikkeling van } \\
\text { productie-installaties } \\
\text { die zeewiersoorten } \\
\text { beschermen tegen } \\
\text { golfbelasting } \\
\text { Ontwikkeling van } \\
\text { integraal, } \\
\text { natuurversterkend } \\
\text { verankeringsconcept } \\
\text { dat uitgerold kan } \\
\text { worden binnen nieuw } \\
\text { te bouwen } \\
\text { windparken } \\
\text { Ontwerp } \\
\text { zeewiersystemen } \\
\text { o.b.v. uitkomsten } \\
\text { onderzoek in } \\
\text { deelprogramma } 3 \text { en } \\
4\end{array}$ & $\begin{array}{l}\text { Testen van } \\
\text { ontwikkelde } \\
\text { installaties in } \\
\text { demovelden in de } \\
\text { Noordzee } \\
\text { Monitoring en } \\
\text { verfijnen van } \\
\text { constructie o.b.v. } \\
\text { uitkomsten } \\
\text { deelprogramma's }\end{array}$ & $\begin{array}{l}\text { Installatie en testen } \\
\text { grootschalige } \\
\text { demovelden in } \\
\text { combinatie met } \\
\text { schelp- en } \\
\text { schaaldierproductie } \\
\text { (en later) viskweek } \\
\text { (100-500 ha) } \\
\text { Offshore incubator } \\
\text { waarbij ondernemers, } \\
\text { kennisinstellingen en } \\
\text { overheid verdere } \\
\text { multi-use innovaties } \\
\text { kunnen onderzoeken }\end{array}$ & $\begin{array}{l}\text { Certificering van } \\
\text { productiesysteemond } \\
\text { erdelen bij oplevering } \\
\text { zodat ondernemers } \\
\text { zeker zijn dat zij } \\
\text { robuuste boerderijen } \\
\text { kopen. }\end{array}$ \\
\hline
\end{tabular}




\begin{tabular}{|c|c|c|c|c|}
\hline Deelprogramma & $\begin{array}{l}\text { Onderzoeksfase } \\
\text { TRL 1-3 } \\
\text { (NWO, KNAW, EU, } \\
\text { Kennis-basis, } \\
\text { strategische } \\
\text { middelen etc.) }\end{array}$ & $\begin{array}{l}\text { Ontwikkelfase TRL } \\
4-6 \\
\text { (toegepast } \\
\text { onderzoek, } \\
\text { beleidsondersteune } \\
\text { nd onderzoek) }\end{array}$ & $\begin{array}{l}\text { Demonstratiefase } \\
\text { TRL 7-9 } \\
\text { (MIT, POP, } \\
\text { fieldlabs, etc.) }\end{array}$ & $\begin{array}{l}\text { Implementatiefase } \\
\text { (subsidies, } \\
\text { investeringen, } \\
\text { regelgeving, } \\
\text { kennisverspreiding, } \\
\text { netwerken, } \\
\text { campagnes etc.) }\end{array}$ \\
\hline $\begin{array}{l}\text { ontwerp acceptabele } \\
\text { effecten hebben op } \\
\text { lokale } \\
\text { nutriëntenconcentrati } \\
\text { e, biodiversiteit, } \\
\text { zeestroming etc. } \\
\text { Gemechaniseerde } \\
\text { ent- en } \\
\text { oogstmethodes }\end{array}$ & $\begin{array}{l}\text { Ontwikkeling van } \\
\text { numerieke modellen } \\
\text { gebaseerd op } \\
\text { realistische data } \\
\text { Ontwikkeling van } \\
\text { gemechaniseerde } \\
\text { ent- en } \\
\text { oogstmethodes }\end{array}$ & & & \\
\hline \multicolumn{5}{|c|}{ 2. Ruimtelijke inpassing op de Noordzee } \\
\hline $\begin{array}{l}\text { Identificeren van } \\
\text { optimale locaties } \\
\text { vanuit integraal } \\
\text { perspectief } \\
\text { (beschikbaarheid } \\
\text { nutriënten, stroming, } \\
\text { golfslag, afstand tot } \\
\text { de kust, } \\
\text { fytoplanktonconcentr } \\
\text { atie i.v.m. combinatie } \\
\text { schelpdierkweek) } \\
\text { Bij medegebruik } \\
\text { binnen } \\
\text { windmolenparken: } \\
\text { waarborgen van } \\
\text { veiligheid voor } \\
\text { medegebruikers }\end{array}$ & $\begin{array}{l}\text { Metingen in de } \\
\text { Noordzee } \\
\text { Modelstudies o.a. op } \\
\text { basis van uitkomsten } \\
\text { onderzoek } \\
\text { deelprogramma } 3 \\
\text { Onderzoek naar } \\
\text { technische en } \\
\text { veiligheidsmaatregele } \\
\text { n die nodig zijn voor } \\
\text { medegebruik binnen } \\
\text { windmolenparken o.a. } \\
\text { op basis van } \\
\text { uitkomsten } \\
\text { deelprogramma } 1\end{array}$ & $\begin{array}{l}\text { Monitoring binnen } \\
\text { demo-velden, } \\
\text { valideren van } \\
\text { modelstudies }\end{array}$ & $\begin{array}{l}\text { Monitoring binnen } \\
\text { demo-velden, } \\
\text { valideren van } \\
\text { modelstudies }\end{array}$ & $\begin{array}{l}\text { Uitkomsten } \\
\text { onderzoek meenemen } \\
\text { in programma van } \\
\text { eisen voor nieuwe } \\
\text { windmolenparken } \\
\text { (kavelbesluiten) }\end{array}$ \\
\hline \multicolumn{5}{|c|}{ 3. Ecologische haalbaarheid en ontwikkeling ecosysteemdiensten } \\
\hline $\begin{array}{l}\text { Zeewierproductieveld } \\
\text { en met een } \\
\text { locatieafhankelijke } \\
\text { omvang zonder } \\
\text { negatieve ecologische } \\
\text { gevolgen voor } \\
\text { nutriënten- } \\
\text { beschikbaarheid, } \\
\text { biodiversiteit, } \\
\text { schaduwwerking, } \\
\text { visstand, bodem, } \\
\text { verspreiding exoten. } \\
\text { Inzicht in ecologische } \\
\text { effecten van } \\
\text { zeewierproductie in } \\
\text { combinatie met } \\
\text { precisiebemesting, } \\
\text { visproductie, en } \\
\text { scheldierproductie. }\end{array}$ & $\begin{array}{l}\text { Ontwikkeling van } \\
\text { technologieën voor } \\
\text { real time monitoring } \\
\text { van diverse } \\
\text { ecologische } \\
\text { parameters } \\
\text { Empirische metingen } \\
\text { binnen demo-velden. } \\
\text { Ontwikkeling van } \\
\text { model- en } \\
\text { scenariostudies } \\
\text { Value Chain analysis: } \\
\text { welke rol speelt } \\
\text { grootschalige } \\
\text { zeewierproductie bij } \\
\text { klimaatadaptatie en } \\
\text { vastlegging van CO2? }\end{array}$ & $\begin{array}{l}\text { Opzetten en } \\
\text { uitvoeren van } \\
\text { monitoringsprogram } \\
\text { ma binnen demo- en } \\
\text { productievelden } \\
\text { Testen van } \\
\text { scenario's. Valideren } \\
\text { van modelstudies } \\
\text { Vaststellen van } \\
\text { ecologische effecten } \\
\text { van } \\
\text { productiesystemen } \\
\text { gecombineerd met } \\
\text { precisiebemesting, } \\
\text { schelpdierproductie } \\
\text { en visproductie, } \\
\text { Ontwikkeling van } \\
\text { systeem voor } \\
\text { verwaarding van } \\
\text { ecosysteemdiensten }\end{array}$ & $\begin{array}{l}\text { Opzetten en } \\
\text { uitvoeren van } \\
\text { monitoringsprogram } \\
\text { ma binnen demo- en } \\
\text { productievelden } \\
\text { Testen van } \\
\text { scenario's. Valideren } \\
\text { van modelstudies } \\
\text { Vaststellen van } \\
\text { ecologische effecten } \\
\text { van } \\
\text { productiesystemen in } \\
\text { gecombineerd met } \\
\text { precisiebemesting, } \\
\text { schelpdierproductie } \\
\text { en visproductie, } \\
\text { Testen van systeem } \\
\text { voor verwaarding van } \\
\text { ecosysteemdiensten }\end{array}$ & $\begin{array}{l}\text { Uitkomsten } \\
\text { onderzoek gebruiken } \\
\text { voor aanpassing } \\
\text { ontwerp offshore } \\
\text { hardware, ruimtelijke } \\
\text { inpassing en } \\
\text { ontwikkeling } \\
\text { duurzame } \\
\text { productiewijze } \\
\text { (deelprogramma } 1,2 \\
\text { en } 4 \text { ) } \\
\text { Uitkomsten } \\
\text { onderzoek meenemen } \\
\text { in programma van } \\
\text { eisen voor nieuwe } \\
\text { windmolenparken bij } \\
\text { medegebruik door } \\
\text { zeewierproductie } \\
\text { (kavelbesluiten) }\end{array}$ \\
\hline
\end{tabular}




\begin{tabular}{|c|c|c|c|c|}
\hline Deelprogramma & $\begin{array}{l}\text { Onderzoeksfase } \\
\text { TRL 1-3 } \\
\text { (NWO, KNAW, EU, } \\
\text { Kennis-basis, } \\
\text { strategische } \\
\text { middelen etc.) }\end{array}$ & $\begin{array}{l}\text { Ontwikkelfase TRL } \\
4-6 \\
\text { (toegepast } \\
\text { onderzoek, } \\
\text { beleidsondersteune } \\
\text { nd onderzoek) }\end{array}$ & $\begin{array}{l}\text { Demonstratiefase } \\
\text { TRL 7-9 } \\
\text { (MIT, POP, } \\
\text { fieldlabs, etc.) }\end{array}$ & $\begin{array}{l}\text { Implementatiefase } \\
\text { (subsidies, } \\
\text { investeringen, } \\
\text { regelgeving, } \\
\text { kennisverspreiding, } \\
\text { netwerken, } \\
\text { campagnes etc.) }\end{array}$ \\
\hline $\begin{array}{l}\text { Zeewierproductie in } \\
\text { combinatie met } \\
\text { natuurontwikkeling. } \\
\text { Maximaliseren } \\
\text { positieve ecologische } \\
\text { effecten } \\
\text { Zeewierproductie in } \\
\text { combinatie met } \\
\text { ecosysteemdiensten } \\
\text { (CO2 vastlegging en } \\
\text { kraamkamerfuncties } \\
\text { voor zeedieren) }\end{array}$ & & $\begin{array}{l}\text { i.s.m. Ngo's en } \\
\text { overheid }\end{array}$ & $\begin{array}{l}\text { i.s.m. Ngo's en } \\
\text { overheid }\end{array}$ & $\begin{array}{l}\text { Implementatie van } \\
\text { systeem voor } \\
\text { verwaarding van } \\
\text { ecosysteemdiensten } \\
\text { i.s.m. Ngo's en } \\
\text { overheid }\end{array}$ \\
\hline \multicolumn{5}{|c|}{ 4. Ontwikkeling duurzame grootschalige productiewijzen } \\
\hline $\begin{array}{l}\text { Productiesystemen } \\
\text { gemaakt van } \\
\text { duurzame materialen } \\
\text { zonder ongewenste } \\
\text { dispersie van } \\
\text { microverontreiniginge } \\
\text { n. } \\
\text { Managementtools en } \\
\text { methodes gericht op } \\
\text { ecologische } \\
\text { verantwoorde } \\
\text { productie en } \\
\text { beheersing/bestrijding } \\
\text { van ziekten, plagen, } \\
\text { ongewenste vestiging } \\
\text { exoten, overwoekering } \\
\text { va productiesystemen. } \\
\text { Zeewierproductie in } \\
\text { combinatie met } \\
\text { precisiebemesting, } \\
\text { visproductie, } \\
\text { scheldierproductie } \\
\text { zonder negatieve } \\
\text { ecologische gevolgen. }\end{array}$ & $\begin{array}{l}\text { Testen dispersie van } \\
\text { microverontreiniging } \\
\text { en. Uitkomsten } \\
\text { benutten in } \\
\text { deelprogramma } 1 \\
\text { Inventariseren } \\
\text { mogelijke ziekten en } \\
\text { plagen. Ontwikkeling } \\
\text { van Integrated Pest } \\
\text { Management (IPM) } \\
\text { Ontwikkeling van } \\
\text { duurzame } \\
\text { productiesystemen in } \\
\text { combinatie met } \\
\text { precisiebemesting, } \\
\text { schelpdierproductie } \\
\text { of visproductie o.b.v. } \\
\text { uitkomsten } \\
\text { deelprogramma } 3 \\
\text { Ontwikkeling van } \\
\text { jaarrondteelten en } \\
\text { wisselteelten } \\
\text { Ontwikkeling van } \\
\text { systemen voor } \\
\text { monitoring van groei } \\
\text { en kwaliteit op } \\
\text { afstand }\end{array}$ & $\begin{array}{l}\text { Monitoring van het } \\
\text { optreden van ziekten } \\
\text { en plagen in demo- } \\
\text { velden. Testen eerste } \\
\text { IPM aanpak bij } \\
\text { eventuele uitbraken } \\
\text { Testen van } \\
\text { productiesystemen in } \\
\text { combinatie met } \\
\text { precisiebemesting, } \\
\text { schelpdierproductie } \\
\text { en visproductie } \\
\text { zonder negatieve } \\
\text { ecologische gevolgen } \\
\text { Implementatie en } \\
\text { testen van in situ } \\
\text { sensoren voor groei } \\
\text { en kwaliteit in demo- } \\
\text { velden. } \\
\text { Testen } \\
\text { jaarrondteelten en } \\
\text { wisselteelten in } \\
\text { demo-velden }\end{array}$ & $\begin{array}{l}\text { Monitoring van het } \\
\text { optreden van } \\
\text { ziekten en plagen in } \\
\text { demo-velden. } \\
\text { Testen eerste IPM } \\
\text { aanpak bij eventuele } \\
\text { uitbraken i.s.m. } \\
\text { ondernemers } \\
\text { Testen van } \\
\text { productiesystemen } \\
\text { in combinatie met } \\
\text { precisiebemesting, } \\
\text { schelpdierproductie } \\
\text { en visproductie } \\
\text { zonder negatieve } \\
\text { ecologische } \\
\text { gevolgen i.s.m. } \\
\text { ondernemers } \\
\text { Testen } \\
\text { jaarrondteelten en } \\
\text { wisselteelten i.s.m. } \\
\text { ondernemers }\end{array}$ & $\begin{array}{l}\text { Toepassing van } \\
\text { ontwikkelde } \\
\text { methodieken en } \\
\text { systemen in } \\
\text { commerciële } \\
\text { productievelden }\end{array}$ \\
\hline \multicolumn{5}{|c|}{ 5. Fysiologie en veredeling van Noordzeesoorten } \\
\hline $\begin{array}{l}\text { Opbrengst (o.a. van } \\
\text { hoogwaardige } \\
\text { inhoudsstoffen) die } \\
\text { boven de kostprijs } \\
\text { uitkomt. } \\
\text { Herkomst en selectie } \\
\text { van goed } \\
\text { uitgangsmateriaal. } \\
\text { Goede }\end{array}$ & $\begin{array}{l}\text { Verdiepende kennis } \\
\text { over genetica, } \\
\text { fysiologie, morfologie } \\
\text { van } \\
\text { Noordzeesoorten. } \\
\text { Brede inventarisatie } \\
\text { Noordzeesoorten en } \\
\text { eigenschappen } \\
\text { daarvan i.r.t. seizoen }\end{array}$ & $\begin{array}{l}\text { Veldexperimenten } \\
\text { met geselecteerde } \\
\text { cultivars in demo- } \\
\text { velden. } \\
\text { Implementatie van in } \\
\text { situ sensoren, testen } \\
\text { van indicatoren voor } \\
\text { groei en kwaliteit, }\end{array}$ & $\begin{array}{l}\text { Centrale demo- } \\
\text { velden waarbij } \\
\text { ondernemers, } \\
\text { onderzoeksinstelling } \\
\text { en en overheid } \\
\text { doorlopend } \\
\text { onderzoek kunnen } \\
\text { doen naar nieuwe }\end{array}$ & $\begin{array}{l}\text { Gebruik van veredelde } \\
\text { rassen en ontwikkelde } \\
\text { methodes in } \\
\text { commerciële } \\
\text { zeewierproductievelde } \\
\text { n }\end{array}$ \\
\hline
\end{tabular}




\begin{tabular}{|c|c|c|c|c|}
\hline Deelprogramma & $\begin{array}{l}\text { Onderzoeksfase } \\
\text { TRL 1-3 } \\
\text { (NWO, KNAW, EU, } \\
\text { Kennis-basis, } \\
\text { strategische } \\
\text { middelen etc.) }\end{array}$ & $\begin{array}{l}\text { Ontwikkelfase TRL } \\
4-6 \\
\text { (toegepast } \\
\text { onderzoek, } \\
\text { beleidsondersteune } \\
\text { nd onderzoek) }\end{array}$ & $\begin{array}{l}\text { Demonstratiefase } \\
\text { TRL 7-9 } \\
\text { (MIT, POP, } \\
\text { fieldlabs, etc.) }\end{array}$ & $\begin{array}{l}\text { Implementatiefase } \\
\text { (subsidies, } \\
\text { investeringen, } \\
\text { regelgeving, } \\
\text { kennisverspreiding, } \\
\text { netwerken, } \\
\text { campagnes etc.) }\end{array}$ \\
\hline $\begin{array}{l}\text { reproductietechnieken } \\
\text { beschikbaar. } \\
\text { Toelating van nieuwe } \\
\text { zeewiersoorten en } \\
\text { rassen zonder } \\
\text { bedreiging voor } \\
\text { biodiversiteit } \\
\text { Optimale } \\
\text { oogstfrequentie } \\
\text { Selectie van } \\
\text { zeewiersoorten die } \\
\text { minder gevoelig zijn } \\
\text { voor ophoping van } \\
\text { verontreinigingen die } \\
\text { bedreiging vormen } \\
\text { voor voedselveiligheid. }\end{array}$ & $\begin{array}{l}\text { en andere factoren. } \\
\text { Vaststellen maximale } \\
\text { opbrengst in de } \\
\text { Noordzee } \\
\text { Opzetten en beheren } \\
\text { genenbank van } \\
\text { Noordzeesoorten } \\
\text { Ontwikkeling van } \\
\text { goede } \\
\text { reproductietechnieke } \\
\text { n. } \\
\text { Veredeling en } \\
\text { selectie van nieuwe } \\
\text { rassen op basis van } \\
\text { genotypische en } \\
\text { fenotypische } \\
\text { kenmerken } \\
\text { Toelatingsonderzoek } \\
\text { nieuwe soorten } \\
\text { Ontwikkelen van } \\
\text { optimale } \\
\text { oogstfrequentie van } \\
\text { diverse soorten. }\end{array}$ & $\begin{array}{l}\text { testen rotatieteelten } \\
\text { in demo-velden }\end{array}$ & $\begin{array}{l}\text { zeewiersoorten en } \\
\text { productiettechnieken }\end{array}$ & \\
\hline \multicolumn{5}{|c|}{ 6. Verwerking geoogste biomassa en ontwikkeling fractioneringstechnieken } \\
\hline $\begin{array}{l}\text { Voorbewerking en } \\
\text { bewaring van } \\
\text { geoogste biomassa } \\
\text { dichtbij het kweekveld } \\
\text { en in nabij gelegen } \\
\text { havens } \\
\text { Extractie van } \\
\text { hoogwaardige } \\
\text { componenten } \\
\text { (hydrocolloïden, } \\
\text { koolhydraten, } \\
\text { eiwitten, steroïden, } \\
\text { polyphenolen etc.). } \\
\text { Benutting als } \\
\text { grondstof voor } \\
\text { voedings- en } \\
\text { chemische industrie }\end{array}$ & $\begin{array}{l}\text { Ontwikkeling } \\
\text { voorbewerkings- en } \\
\text { bewaringstechnieken } \\
\text { Ontwikkeling } \\
\text { fractionerings- } \\
\text { technologieën en } \\
\text { isolatie van } \\
\text { functionele } \\
\text { componenten in } \\
\text { geoogst materiaal. } \\
\text { Proof of principle op } \\
\text { labschaal }\end{array}$ & $\begin{array}{l}\text { Opschaling } \\
\text { voorbewerkings- en } \\
\text { bewaringstechnieken } \\
\text { naar demoschaal } \\
\text { Opschaling } \\
\text { fractionering- } \\
\text { technologieën naar } \\
\text { demoschaal. } \\
\text { Ontwikkeling van } \\
\text { business i.s.m. } \\
\text { deelprogramma } 7\end{array}$ & $\begin{array}{l}\text { Opschaling naar } \\
\text { industriële schaal }\end{array}$ & $\begin{array}{l}\text { Certificering van } \\
\text { zeewiergrondstoffen }\end{array}$ \\
\hline \multicolumn{5}{|c|}{ 7. Economische haalbaarheid: ontwikkeling van afzet en business cases } \\
\hline $\begin{array}{l}\text { Noordzeewier als } \\
\text { product voor humane } \\
\text { consumptie en } \\
\text { ingrediënt voor de } \\
\text { voedingsmiddelenmar }\end{array}$ & $\begin{array}{l}\text { Vaststellen van } \\
\text { drivers/barrières voor } \\
\text { consumptie van (vers) } \\
\text { zeewier. Testen van } \\
\text { gezondheidsclaims en }\end{array}$ & $\begin{array}{l}\text { Ontwikkeling van } \\
\text { producten. Testen } \\
\text { van } \\
\text { consumentenaccepta } \\
\text { tie. }\end{array}$ & $\begin{array}{l}\text { Testen ontwikkelde } \\
\text { producten i.s.m. } \\
\text { voedingsindustrie }\end{array}$ & $\begin{array}{l}\text { Publieksinformatie } \\
\text { over zeewier uit de } \\
\text { Noordzee als } \\
\text { voedselproduct. } \\
\text { Ontwikkeling van }\end{array}$ \\
\hline
\end{tabular}




\begin{tabular}{|c|c|c|c|c|}
\hline Deelprogramma & $\begin{array}{l}\text { Onderzoeksfase } \\
\text { TRL 1-3 } \\
\text { (NWO, KNAW, EU, } \\
\text { Kennis-basis, } \\
\text { strategische } \\
\text { middelen etc.) }\end{array}$ & $\begin{array}{l}\text { Ontwikkelfase TRL } \\
4-6 \\
\text { (toegepast } \\
\text { onderzoek, } \\
\text { beleidsondersteune } \\
\text { nd onderzoek) }\end{array}$ & $\begin{array}{l}\text { Demonstratiefase } \\
\text { TRL 7-9 } \\
\text { (MIT, POP, } \\
\text { fieldlabs, etc.) }\end{array}$ & $\begin{array}{l}\text { Implementatiefase } \\
\text { (subsidies, } \\
\text { investeringen, } \\
\text { regelgeving, } \\
\text { kennisverspreiding, } \\
\text { netwerken, } \\
\text { campagnes etc.) } \\
\end{array}$ \\
\hline $\begin{array}{l}\text { kt. Ontwikkeling van } \\
\text { consumentenmarkt. }\end{array}$ & $\begin{array}{l}\text { onderliggende } \\
\text { mechanismen hierbij. } \\
\text { Analyse } \\
\text { duurzaamheids-claims } \\
\text { en, } \\
\text { voedselveiligheids- } \\
\text { aspecten }\end{array}$ & $\begin{array}{l}\text { Opbouwen novel } \\
\text { food dossier } \\
\text { Value Chain Analysis } \\
\text { (baten voor } \\
\text { zeewierteler) }\end{array}$ & & $\begin{array}{l}\text { maatschappelijk } \\
\text { draagvlak. } \\
\text { Marktintroductie van } \\
\text { ontwikkelde producten } \\
\text { Opzetten van } \\
\text { ondersteuningsinstrum } \\
\text { enten die } \\
\text { ondernemers } \\
\text { tegemoet komt bij } \\
\text { marktintroductie van } \\
\text { in eerste instantie } \\
\text { duurder Nederlands } \\
\text { zeewier conform een } \\
\text { SDE regeling bij } \\
\text { duurzame energie. }\end{array}$ \\
\hline $\begin{array}{l}\text { Noordzeewier als } \\
\text { product voor dierlijke } \\
\text { consumptie en } \\
\text { ingrediënt in } \\
\text { diervoeder }\end{array}$ & $\begin{array}{l}\text { Testen van } \\
\text { nutritionele en bio- } \\
\text { functionele } \\
\text { eigenschappen } \\
\text { (gezondheid- } \\
\text { bevorderende } \\
\text { werking, reductie } \\
\text { uitstoot van methaan } \\
\text { door runderen) en } \\
\text { onderliggend } \\
\text { mechanisme hiervan. } \\
\text { Analyse } \\
\text { duurzaamheidsclaims } \\
\text { en, } \\
\text { voedselveiligheidsasp } \\
\text { ecten }\end{array}$ & $\begin{array}{l}\text { Ontwikkelen van } \\
\text { producten en } \\
\text { uittesten hiervan bij } \\
\text { landbouwhuisdieren } \\
\text { Value Chain Analysis } \\
\text { (baten voor } \\
\text { zeewierteler) }\end{array}$ & $\begin{array}{l}\text { Testen ontwikkelde } \\
\text { producten i.s.m. } \\
\text { veevoederindustrie }\end{array}$ & $\begin{array}{l}\text { Marktintroductie van } \\
\text { ontwikkelde producten } \\
\text { Opzetten van } \\
\text { ondersteuningsinstrum } \\
\text { enten die } \\
\text { ondernemers } \\
\text { tegemoet komt bij } \\
\text { marktintroductie. }\end{array}$ \\
\hline $\begin{array}{l}\text { Noordzeewier als bio- } \\
\text { stimulant en gewas- } \\
\text { beschermingsproduct. }\end{array}$ & $\begin{array}{l}\text { Testen van effecten } \\
\text { op bodem- en } \\
\text { gewasgezondheid, } \\
\text { welke bewerkingen } \\
\text { zijn nodig? Vaststellen } \\
\text { van } \\
\text { werkingsmechanisme, } \\
\text { evalueren van } \\
\text { duurzaamheidseffecte } \\
\mathrm{n}\end{array}$ & $\begin{array}{l}\text { Veldexperimenten } \\
\text { met } \\
\text { productformuleringen } \\
\text { en doseringen, } \\
\text { verwerking tot } \\
\text { producten voor } \\
\text { agrarische } \\
\text { ondernemers, } \\
\text { Onderzoek t.b.v. } \\
\text { toelating als } \\
\text { bijzondere meststof } \\
\text { of plantenstimulant } \\
\text { Value Chain Analysis } \\
\text { (baten voor } \\
\text { zeewierteler) }\end{array}$ & $\begin{array}{l}\text { Testen van } \\
\text { producten i.s.m. } \\
\text { gewastelers en } \\
\text { producten } \\
\text { gewasbeschermings } \\
\text { middelen } \\
\text { Regelen van } \\
\text { wettelijk kader. }\end{array}$ & $\begin{array}{l}\text { Marktintroductie van } \\
\text { ontwikkelde producten } \\
\text { Opzetten van } \\
\text { ondersteuningsinstrum } \\
\text { enten die } \\
\text { ondernemers } \\
\text { tegemoet komt bij } \\
\text { marktintroductie. }\end{array}$ \\
\hline $\begin{array}{l}\text { Afzet van geïsoleerde } \\
\text { componenten als } \\
\text { grondstof voor } \\
\text { chemische industrie. }\end{array}$ & $\begin{array}{l}\text { Ontwikkeling i.s.m. } \\
\text { deelprogramma 6: } \\
\text { welke markten bieden } \\
\text { kansen? }\end{array}$ & $\begin{array}{l}\text { Prototypes gereed. } \\
\text { Ketenontwikkeling } \\
\text { i.s.m. verwerkende }\end{array}$ & $\begin{array}{l}\text { Opschaling naar } \\
\text { industriële schaal }\end{array}$ & $\begin{array}{l}\text { Marktintroductie van } \\
\text { ontwikkelde producten } \\
\text { Opzetten van } \\
\text { ondersteuningsinstrum }\end{array}$ \\
\hline
\end{tabular}




\begin{tabular}{|c|c|c|c|c|}
\hline Deelprogramma & $\begin{array}{l}\text { Onderzoeksfase } \\
\text { TRL 1-3 } \\
\text { (NWO, KNAW, EU, } \\
\text { Kennis-basis, } \\
\text { strategische } \\
\text { middelen etc.) }\end{array}$ & $\begin{array}{l}\text { Ontwikkelfase TRL } \\
4-6 \\
\text { (toegepast } \\
\text { onderzoek, } \\
\text { beleidsondersteune } \\
\text { nd onderzoek) }\end{array}$ & $\begin{array}{l}\text { Demonstratiefase } \\
\text { TRL 7-9 } \\
\text { (MIT, POP, } \\
\text { fieldlabs, etc.) }\end{array}$ & $\begin{array}{l}\text { Implementatiefase } \\
\text { (subsidies, } \\
\text { investeringen, } \\
\text { regelgeving, } \\
\text { kennisverspreiding, } \\
\text { netwerken, } \\
\text { campagnes etc.) }\end{array}$ \\
\hline & & $\begin{array}{l}\text { en chemische } \\
\text { industrie. }\end{array}$ & & $\begin{array}{l}\text { enten die } \\
\text { ondernemers } \\
\text { tegemoet komt bij } \\
\text { marktintroductie. }\end{array}$ \\
\hline $\begin{array}{l}\text { Integratie van diverse } \\
\text { verwerkingsmethoden } \\
\text { voor beste } \\
\text { vierkantsverwaarding }\end{array}$ & $\begin{array}{l}\text { Ontwikkeling en } \\
\text { inrichting van } \\
\text { verwerkingslocaties } \\
\text { om de geoogste } \\
\text { biomassa zo } \\
\text { hoogwaardig, } \\
\text { waardevol en effectief } \\
\text { mogelijk af te zetten } \\
\text { in de diverse } \\
\text { deelmarkten }\end{array}$ & $\begin{array}{l}\text { Verwaardings- } \\
\text { rotondes op } \\
\text { pilotschaal realiseren } \\
\text { in diverse } \\
\text { havensteden (in de } \\
\text { buurt van } \\
\text { grootschalige pilots) }\end{array}$ & $\begin{array}{l}\text { Opschaling naar } \\
\text { industriële schaal }\end{array}$ & $\begin{array}{l}\text { Marktintroductie van } \\
\text { ontwikkelde producten } \\
\text { Opzetten van } \\
\text { ondersteuningsinstrum } \\
\text { enten die } \\
\text { ondernemers } \\
\text { tegemoet komt bij } \\
\text { marktintroductie. }\end{array}$ \\
\hline $\begin{array}{l}\text { Zeewierproductie in } \\
\text { combinatie met } \\
\text { schepdierproductie en } \\
\text { ecosysteemdiensten } \\
\text { i.s.m. deelprogramma } \\
3 \text { en } 4\end{array}$ & $\begin{array}{l}\text { Zie informatie bij } \\
\text { deelprogramma } 3 \text { en } \\
4\end{array}$ & $\begin{array}{l}\text { Zie informatie bij } \\
\text { deelprogramma } 3 \text { en } \\
4\end{array}$ & $\begin{array}{l}\text { Zie informatie bij } \\
\text { deelprogramma } 3 \text { en } \\
4\end{array}$ & $\begin{array}{l}\text { Zie informatie bij } \\
\text { deelprogramma } 3 \text { en } 4\end{array}$ \\
\hline $\begin{array}{l}\text { Stimuleren van } \\
\text { marktontwikkeling }\end{array}$ & $\begin{array}{l}\text { Hoe kan } \\
\text { marktontwikkeling } \\
\text { duurzaam } \\
\text { gestimuleerd worden? } \\
\text { Wat zijn de juiste } \\
\text { indicatoren om } \\
\text { marktontwikkeling te } \\
\text { meten? }\end{array}$ & $\begin{array}{l}\text { Samenwerking met } \\
\text { financiers verkennen } \\
\text { en opzetten om } \\
\text { indicatoren en } \\
\text { marktontwikkelings- } \\
\text { cijfers te testen }\end{array}$ & $\begin{array}{l}\text { Marktcijfers } \\
\text { verzamelen }\end{array}$ & $\begin{array}{l}\text { Marktcijfers en andere } \\
\text { relevante indicatoren } \\
\text { delen met } \\
\text { bedrijfsleven en } \\
\text { maatschappij }\end{array}$ \\
\hline $\begin{array}{l}\text { Macro-economische } \\
\text { baten van } \\
\text { grootschalige } \\
\text { zeewierproductie. } \\
\text { Ontwikkeling human } \\
\text { capital agenda. }\end{array}$ & $\begin{array}{l}\text { Vaststellen } \\
\text { duurzaamheid (incl. } \\
\text { co2-footprint) van de } \\
\text { gehele zeewierketen. } \\
\text { Inventariseren van } \\
\text { noodzakelijke } \\
\text { ontwikkelingen in } \\
\text { beroepsonderwijs }\end{array}$ & & $\begin{array}{l}\text { Ontwikkeling van } \\
\text { een } \\
\text { zeewierkenniscentru } \\
\mathrm{m} \text { voor ondernemers } \\
\text { en maatschappij }\end{array}$ & $\begin{array}{l}\text { Oprichting van een } \\
\text { zeewierkenniscentrum } \\
\text { voor ondernemers en } \\
\text { maatschappij }\end{array}$ \\
\hline \multicolumn{5}{|c|}{ 8. Bestuurlijke aspecten, wet- \& regelgeving } \\
\hline $\begin{array}{l}\text { Regelgevend kader } \\
\text { voor grootschalige } \\
\text { aquacultuur (zeewier- } \\
\text { en mosselproductie) in } \\
\text { de Noordzee } \\
\text { Wet- en regelgeving } \\
\text { m.b.t. toegang en } \\
\text { medegebruik binnen } \\
\text { windmolenparken. } \\
\text { Bescherming van het } \\
\text { mariene ecosysteem. }\end{array}$ & $\begin{array}{l}\text { Ontwikkeling van } \\
\text { regelgevend kader } \\
\text { voor grootschalige } \\
\text { aquacultuur (zeewier- } \\
\text { en mosselproductie) in } \\
\text { de Noordzee i.s.m. } \\
\text { deelprogramma } 4 . \\
\text { Analyse van risico's en } \\
\text { aansprakelijkheden bij } \\
\text { medegebruik binnen } \\
\text { windmolenparken. } \\
\text { Analyseren welke }\end{array}$ & $\begin{array}{l}\text { Ontwikkeling van } \\
\text { wetgeving voor } \\
\text { medegebruik binnen } \\
\text { windmolenparken en } \\
\text { aansprakelijkheden. } \\
\text { Ontwikkeling van } \\
\text { een richtinggevend } \\
\text { kader voor het } \\
\text { aanwijzen van } \\
\text { productiegebieden } \\
\text { i.s.m. } \\
\text { deelprogramma } 2 \\
\end{array}$ & $\begin{array}{l}\text { Toetsen van } \\
\text { ontwikkelde } \\
\text { wetgeving binnen } \\
\text { windmolenparken en } \\
\text { grootschalige } \\
\text { demovelden. }\end{array}$ & $\begin{array}{l}\text { Implementatie van } \\
\text { ontwikkelde wetgeving } \\
\text { Aanwijzen van } \\
\text { productiegebieden } \\
\text { Implementatie van } \\
\text { een } \\
\text { milieumonitoringssyste } \\
\text { em bij grootschalige } \\
\text { productievelden } \\
\text { Stimuleringsinstrumen } \\
\text { ten en garantiestelling } \\
\text { voor voorinvestering } \\
\end{array}$ \\
\hline
\end{tabular}




\begin{tabular}{|c|c|c|c|c|}
\hline Deelprogramma & $\begin{array}{l}\text { Onderzoeksfase } \\
\text { TRL 1-3 } \\
\text { (NWO, KNAW, EU, } \\
\text { Kennis-basis, } \\
\text { strategische } \\
\text { middelen etc.) }\end{array}$ & $\begin{array}{l}\text { Ontwikkelfase TRL } \\
\text { 4-6 } \\
\text { (toegepast } \\
\text { onderzoek, } \\
\text { beleidsondersteune } \\
\text { nd onderzoek) }\end{array}$ & $\begin{array}{l}\text { Demonstratiefase } \\
\text { TRL 7-9 } \\
\text { (MIT, POP, } \\
\text { fieldlabs, etc.) }\end{array}$ & $\begin{array}{l}\text { Implementatiefase } \\
\text { (subsidies, } \\
\text { investeringen, } \\
\text { regelgeving, } \\
\text { kennisverspreiding, } \\
\text { netwerken, } \\
\text { campagnes etc.) }\end{array}$ \\
\hline $\begin{array}{l}\text { Certificering van } \\
\text { verwerking van } \\
\text { biomassa en } \\
\text { toepassingen hiervan } \\
\text { in veilige en duurzame } \\
\text { producten }\end{array}$ & $\begin{array}{l}\text { aanpassingen in } \\
\text { kavelbesluiten voor } \\
\text { nieuwe } \\
\text { windmolenparken } \\
\text { nodig zijn. } \\
\text { Ontwikkeling van } \\
\text { wetgeving t.a.v. } \\
\text { milieueffectrapportage } \\
\text { s en langjarige } \\
\text { ecologische monitoring } \\
\text { bij grootschalige } \\
\text { productie i.s.m. } \\
\text { deelprogramma } 3 . \\
\text { Ontwikkeling van wet- } \\
\text { en regelgeving t.a.v. } \\
\text { verwerking van } \\
\text { geoogste biomassa en } \\
\text { certificeren van } \\
\text { toepassingen in veilige } \\
\text { en duurzame } \\
\text { producten i.s.m. } \\
\text { deelprogramma } 6 \text { en } 7\end{array}$ & $\begin{array}{l}\text { Ontwikkeling van } \\
\text { vergunningsprocedu } \\
\text { res. }\end{array}$ & & $\begin{array}{l}\text { die ondernemers in } \\
\text { staat stelt te gaan } \\
\text { produceren. De } \\
\text { stimuleringsinstrument } \\
\text { en worden zo ingericht } \\
\text { dat de zeewiersector } \\
\text { wordt "uitgedaagd" } \\
\text { om de investerings- en } \\
\text { operationele kosten te } \\
\text { reduceren } \\
\text { Publieksinformatie } \\
\text { over producten en } \\
\text { diensten van de } \\
\text { Noordzee. } \\
\text { Ontwikkeling van } \\
\text { maatschappelijk } \\
\text { draagvlak. }\end{array}$ \\
\hline
\end{tabular}

\section{Sterktes en zwaktes kennispositie Nederland en positie van bedrijfsleven}

Een groot deel van de Noordzee zal tot 2050 worden ingericht voor windmolenparken. Dit is 14.000 $\mathrm{km} 2$. Deskundigen suggereren op basis van schattingen van de natuurlijke ecologische draagkracht van de Noordzee dat een maximale zeewierproductie van enkele honderden vierkante kilometers binnen het Nederlands deel van de Noordzee mogelijk is (Van Duren et al., 2019). Dit komt overeen met het uitgangspunt van de zeewiersector zelf. Zij streven naar $500 \mathrm{~km}^{2}$ Noordzee voor multifunctionele zeewierproductie. Dit is een oppervlak ter grootte van ongeveer $25 \%$ van het Nederlandse landbouwareaal. Het ruimtelijk potentieel is dus enorm. Dr. Sander van den Burg (Wageningen Economic Research) heeft berekend dat een zeewierproductieveld van $400 \mathrm{~km}^{2}$ in theorie een opbrengst kan leveren van circa 800 miljoen $\mathrm{kg}$ droge stof zeewier per jaar. Hij laat ook zien wat dit kan betekenen: het bedrijf Umameats produceert een hybride hamburger waarin $15 \%$ zeewier verwerkt wordt. Bij een hamburger van $100 \mathrm{~g}$ betekent dat $15 \mathrm{gram}$ zeewier. Indien de theoretische zeewieropbrengst van 400 km2 jaarlijks volledig gebruikt wordt voor de productie van dergelijke hybride hamburgers dan levert dit 53 miljoen burgers op. Dat zijn respectievelijk 5 hamburgers per persoon per jaar in Nederland. Als dat zeewier 1-op-1 rundvlees vervangt, is er substantieel minder rundvlees nodig.

Op dit moment vindt er nog geen grootschalige zeewierteelt ( $>10 \mathrm{ha}$ ) plaats op de Noordzee. De keten dient nog grotendeels ontwikkeld te worden. Dit is een enorme innovatieopgave. Het benoemen van zeewierproductie in de Noordzee als nationale doelstelling in het klimaatakkoord is een belangrijke stap om dit mogelijk te maken. Een volgende stap is het ontwikkelen van het juiste innovatiebeleid en een doeltreffend stimuleringsinstrumentarium.

\section{Samenhang met (bestaande) nationale en internationale agenda's en strategie}

Samenwerking en afstemming met andere Noordzeelanden is wenselijk, o.a. bij de positiebepaling van toekomstige zeewiervelden in de Noordzee grenzend aan territoriale wateren van omringende landen. Internationaal kan er samengewerkt worden op het gebied van onderzoek, pilots, ondernemerschap en 
marktontwikkeling.

Relevante nationale en internationale agenda's zijn:

- Innoveren met een missie. Integrale kennis- en innovatieagenda voor klimaat en energie. Taakgroep innovatie Klimaatakkoord (maart 2019)

- De toekomst van de Noordzee. De Noordzee in 2030 en 2050: een scenariostudie. Planbureau voor de Leefomgeving

- Strategische Agenda Noordzee 2030 en het daaraan gekoppelde traject rond het Noordzee Akkoord door het Overlegorgaan Fysieke Leefomgeving (OFL)

- $\quad$ Europese Blue Growth Strategie 2020

- Noordzeewier 2030, sectorplan voor de zeewierketen en boerderijen op zee. Stichting Noordzeeboerderij

De belangrijkste internationale strategie die relevant is voor dit MMIP is de Europese Blue Growth Strategy 2020, als onderdeel van de Europese strategie voor slimme, duurzame en inclusieve blauwe groei. Daarnaast zijn er diverse Europese richtlijnen die de kaders stellen voor medegebruik van het Noordzee ecosysteem, waaronder verplichtingen voor natuurbescherming (inclusief het aanwijzen van beschermde gebieden) en de duurzame exploitatie van visbestanden. Voor de exploitatie van wind is er geen Europese strategie of regelgeving, met dien verstande dat de aanleg van windparken (en andere vormen van energie- en grondstoffenwinning) moeten voldoen aan de Natura2000 regelgeving.

In Nederland wordt vanuit het OFL (overlegorgaan Fysieke Leefomgeving) gewerkt aan het Noordzee Akkoord, waarbij het vooral gaat om ruimtelijke afspraken over energie, voedsel en natuur op de Noordzee. Dit Noordzee Akkoord moet in de zomer 2019 gereed zijn. De uitkomsten hiervan hebben mogelijk gevolgen voor de focus van het voorliggende MMIP en de daaraan gekoppelde MMIPs voor Noordzee en Visserij

\section{Betrokken sectoren en opties voor consortia en financiering}

Het ontwikkelen van een volwaardige zeewierketen op de Noordzee, die zichzelf economisch in stand kan houden in combinatie met natuurontwikkeling en commerciële schelpdierteelt, vergt een multidisciplinaire ketenaanpak. Zeewierondernemers, kennisinstellingen en overheden werken hierbij nauw samen in grootschalige demo-projecten (binnen en buiten windparken) inclusief aanlandingsplekken in specifieke havens. Door hiervoor specifieke locaties centraal te stellen kunnen daar stappen gezet worden om de keten te ontwikkelen.

Overheden zorgen voor het noodzakelijke wettelijke kader en creëren de juiste beleidsinstrumenten. Kennisinstellingen (TO2-instituten, universiteiten, KNAW-instituten, Hogescholen) dragen bij in de vorm van (nieuwe) kennis die nodig is om innovaties te realiseren. Fundamentele onderzoekprogramma's worden gefinancierd door NWO en/of middelen voor kennisbasisonderzoek van de TO2-instituten. Het meer toegepaste en praktijkonderzoek wordt o.a. gefinancierd in de vorm van publiek-private samenwerking waarbij o.a. TKI-Maritiem, TKI-Agri \& Food en TKI-Wind op Zee een faciliterende rol vervullen. Onderzoeksvragen en resultaten worden gecoördineerd door een nationaal kenniscentrum Zeewier dat o.a. fungeert als kennismakelaar. Met hulp van stimuleringsinstrumenten kunnen zeewierondernemers voorinvesteringen doen in nieuwe grootschalige productievelden, die deels ook ingezet kunnen worden voor onderzoek en monitoring. Young professionals die in de zeewiersector willen werken worden gefaciliteerd met training en opleiding via het beroepsonderwijs. 
Wageningen Marine Research

T: $+31(0) 317480900$

E: marine-research@wur.nl

www.wur.nl/marine-research

Bezoekers adres:

- Ankerpark 271781 AG Den Helder

- Korringaweg 7, 4401 NT Yerseke

- Haringkade 1, 1976 CP IJmuiden
Wageningen Marine Research levert met kennis, onafhankelijk wetenschappelijk onderzoek en advies een wezenlijke bijdrage aan een duurzamer, zorgvuldiger beheer, gebruik en bescherming van de natuurlijke rijkdommen in zee-, kust- en zoetwatergebieden.
Wageningen Marine Research is onderdeel van Wageningen University \& Research. Wageningen University \& Research is het samenwerkingsverband tussen Wageningen University en Stichting Wageningen Research en heeft als missie: 'To explore the potential of nature to improve the quality of life' 